UNIVERSIDADE DE SÃO PAULO

INSTITUTO DE PSICOLOGIA

\title{
PSICANÁLISE NO FRONT: A POSIÇÃO DO ANALISTA E AS MARCAS DO TRAUMA NA CLÍNICA COM MIGRANTES
}

ANA C. C. GEBRIM

São Paulo

2018 
ANA C. C. GEBRIM

\section{Psicanálise no front: a posição do analista e as marcas do trauma na clínica com migrantes}

\section{(Versão Corrigida)}

Tese apresentada para a obtenção do título de doutora (dupla-titulação) no âmbito do convênio acadêmico para coorientação de tese celebrado pelo Instituto de Psicologia da Universidade de São Paulo e pelo Institut National de Langues et Civilisations Orientales - INALCO.

Orientadora: Profa. Dra. Miriam Debieux Rosa Coorientadora: Profa. Dra. Marie-Caroline Saglio-Yatzimirsky

São Paulo 
GEBRIM, Ana C. C.

\section{Título}

Psicanálise no front: a posição do analista e as marcas do trauma na clínica com migrantes.

Tese apresentada ao Instituto de Psicologia da Universidade de São

Paulo para obtenção do título de Doutora em Psicologia Clínica.

Orientadora: Profa. Dra. Miriam Debieux Rosa

Coorientadora: Profa. Dra. Marie-Caroline Saglio-Yatzimirsky

Aprovado em:

Banca Examinadora

Profa.Dra. :

Instituição

Assinatura:

Profa.Dra.

Instituição

Assinatura:

Profa.Dra.

Instituição

Assinatura:

Profa.Dra.:

Instituição

Assinatura:

Prof. Dr. :

Instituição

Assinatura:

Prof. Dr. :

Instituição Assinatura: 


\section{AGRADECIMENTOS}

O processo árduo, mas tantas vezes prazeroso, da escrita de uma tese sobre migração só foi possível na medida em que pude eu mesma me desterritorializar constantemente entre temas, histórias, lugares, cidades, países e universidades. Isso se deve também a muitas pessoas envolvidas, a encontros remarcáveis e também à agência pública de fomento, a Capes $^{1}$, pelo financiamento da pesquisa.

Agradeço, em primeiro lugar, a todas as pessoas que confiaram a mim suas histórias, pessoas das mais diversas partes do mundo, que em São Paulo, em Paris e em Beirute estiveram dispostas a se debruçar, ao meu lado, no próprio vivido.

Miriam Debieux Rosa, através da generosidade com que acolheu a estrangeira - que recém desembarcava em seu grupo já constituído, anos atrás, marcou meu percurso de forma indelével. Agradeço profundamente a orientação acolhedora e a supervisão desafiadora sempre capaz de ser tanto terna, quanto firme, assim como a confiança, parceria e a aposta com que sempre recebeu todas as minhas ideias e projetos, os mais malucos.

Marie-Caroline Saglio-Yatzimirsky, que, desde o primeiro encontro, me descortinou um mundo novo e que só me trouxe mais sede de fazer e de saber. Minha profunda admiração pela vivacidade, potência e pelo engajamento com que leva a própria vida, na clínica e na pesquisa. Agradeço imensamente a confiança, a generosidade e o respeito tanto de sua orientação e acolhimento como da forma com que sempre dividiu seu trabalho comigo.

Minha enorme gratidão à Caterina Koltai que, quase como se fosse em outra vida, me mostrou que tudo podia ser muito mais potente e interessante. Se todos os caminhos levam mesmo a Roma, fico pensando em quais os desertos que eu teria camelado para, seguramente, não chegar no mesmo lugar sem aquele encontro nas Ciências Sociais. Obrigada por me mostrar que estrangeiro é também sítio de morada.

À Emília Broide, que com uma leitura generosa produziu ato de autorização da minha escrita em primeira pessoa.

\footnotetext{
1 O presente trabalho foi realizado com apoio da Coordenação de Aperfeiçoamento de Pessoal de Nível Superior - Brasil (CAPES) - Código de Financiamento 001
} 
Ao Gabriel Binkowski, pela delicadeza e perspicácia de uma leitura que teve efeito de nomeação.

À Yanina Otsuka Stasevskas, pela transmissão aguerrida de uma psicanálise política e pelo entusiasmo de uma clínica que se faz com a mão na massa e até o pescoço. Obrigada também por todas as leituras comprometidas e todas as sugestões para esse texto.

À Felicia Knobloch, que, com a intensidade de sua presença, me contaminou desde sempre com a veracidade e potência com que agarra seus temas. Agradeço todas as pontuações, indicações e provocações sempre tão instigantes.

Ao Ricardo Goldenberg, com quem embarquei nessa longa viagem que é uma análise através do amor.

À Maria de Fátima Vicente, à Miriam Chnaiderman, à Maria Helena Fernandes, à Chu Cavalcanti, ao Thamy Ayouch, à Alexandra Galintizie-Loumpet, à Christine Davoudian, à Françoise Davoine, Pascal Dibie e Étienne Tassin (In memorian) pelas produções, supervisões, aulas, conversas e pelas presenças tanto generosas quanto provocativas de mais pensar e mais fazer.

Aos professores Bader Sawaia, Deivison Mendes Faustino e Ivan Estevão por aceitarem gentilmente participar da banca de defesa.

Aos companheiros de trabalho imprescindíveis e que fazem a coisa tomar sentido: à querida Flavia Gleich, pela parceria tão rica de diálogo, construção e pela amizade, ao Pedro Seincman, pelo desafio do desbravamento das bonitas Veredas, à Luciana Carvalho, pela seriedade em todas suas construções, à Ana Cristina Berntz, pela ternura, ao Bruno Monachini, pela presença doce e atenta, ao Tiago Sanches Nogueira, por instigar sempre mais questionamentos e provocações, à Cristina Rocha Dias, pela supervisão sensível, à Viviani Carmo-Huerta, pela ousadia com que introduziu novas intervenções e reflexões em nosso grupo, à Ilana Mountian por apresentar as leituras pós-coloniais e ao querido Marcio Gagliato, pela coragem de sustentar seu front.

Agradeço imensamente aos que toparam a empreitada de um grupo de estudos temerário: Catarina Carneiro Pires, Sofia Chavez, Liana Driga, Kamila Fahs, Cynthia Romão, Andressa Carvalho, Izabel Motta, Rafael Michel Domenes, Anna Mariutti, Ana Carolina Barcellos, Leonora Corsini, Julia Fatio e Larissa Frozel. Obrigada pelas presenças tão instigantes e pelos ouvidos a que endereço inquietações em gestação. 
Agradeço muito a todos os companheiros do Grupo Veredas. Também a Tereza Meirelles, Arthur Tobias e Rafaela Achatz pelas presenças criativas e questionadoras junto ao grupo, na construção dessas veredas.

À Raonna Martins, minha parça na luta permanente de resistência. À Carolina Bertol, pela bonita amizade que nasceu em Paris. À Camila Issa, pela presença la(r)va que se tornou imprescindível. À Ana Mussatti Braga, pela honestidade e profundidade de seus trabalhos tão inspiradores.

Aos queridos colegas do laboratório de pesquisa: Priscilla Santos, Aline de Sousa Martins, Laura Shdaior, Paula Pereira, Marta Okamoto, Gabriela Medeiros, Débora Sereno, Diego Penha, Rodrigo Alencar, Isabel Tatit, Sandra Alencar, Mariana Belluzzi, Joana Sampaio Primo, Marta Cerrutti, Jaquelina Imbrizi, Fernanda Sato, Patricia Ferreira.

A todos os funcionários da Casa do Migrante e da Missão Paz, em especial, à Marcia Lourdes de Araújo, Berenice Young e Elaine da Silva.

A todos os integrantes da Rede de Cuidados em Saúde para Migrantes e Refugiados do Centro de São Paulo.

Aos companheiros durante meu período no Centro de Referência para Refugiados da Caritas: Maria Cristina Morelli, Talitha Yamamoto, Larissa Leite, Vivian Holzhacker, Camila Sombra, Ricardo Felix, Maria do Céu, Adelaide Lemos, Gabriela Cunha Ferraz, seu Francisco, Sueli Ferreira, Lili, Vitor Lopes, Arthur Murta, Laís Azeredo, Felipe Benjamin, Nina Galvão, Nicolas Neves, Isadora, e a aguerrida Luiza Bondenmuller.

Ao Jonas Boni e à Elaine Hara, pelo prazer da parceria e da troca no espaço de trabalho. Pelo compartilhamento cotidiano das angústias, dos medos e também de todas as epifanias e conquistas.

Ao Hasan Zarif e a todos os funcionários do Al Janiah por acolherem com generosidade e empenho o bonito "Veredas convida" que gerou tantas novas questões e provocações.

Agradeço às parceiras da psicanálise durante os anos da formação em paralelo à escrita: Ana Luisa Suriani, Camila Brasiliano, Marcela Rosemberg, Alice Bei e à todos os queridos colegas do Sedes.

Aos amigos absolutamente imprescindíveis durante a empreitada de um mergulho ora ensimesmado, ora compartilhado. Obrigada por todos os colos, os porres, as trocas e a parceria de vida em São Paulo, Brasília, no Rio e em Paris. Com vocês eu compreendo a 
verdadeira função da amizade: Rafael Andreotti, Débora Lessa, Rachel Damico, Paloma Gomes, Isadora Souza, Florian Richaud, Lilian Breschigliaro, Marcelo Rocco, Vilma Bokany, Ellen Ramos, Bruna Domenico, Kristina Speaks, Michelle Barros, Neusely Fernandes, Giane Alvares, Angélica Kuhn, Rafael Bruno Lopes Salgado, Andrea Barros Leal, Francisca Espinoza, Maria Doibani, Heloisa Miura e Otto Miguel.

Aos meus quatro avós, que, com amor - tal qual o andaime do Hassoun - imprimiram em mim tudo que sou para que eu fosse sempre o que quisesse.

À minha mãe, pela firmeza de ser porto, sempre; e por apontar os caminhos como um farol.

Ao meu pai, por me transmitir a bravura de ansiar um mundo sem fronteiras; e pela militância que corre nas veias.

Aos meus dois irmãos, à minha madrasta e ao meu padrasto, pela riqueza de uma família envolta em tanto amor e admiração um pelo outro.

À Gianna, que pela potência do encontro me devolveu a escrita, a cor e produziu deslocamento em todas placas tectônicas. Obrigada pelo Rio e pelo nós sem medo. 
You don't know me

Bet you'll never get to know me

You don't know me at all

Feel so lonely

The world is spinning round slowly

There's nothing you can show me

From behind the wall

Show me from behind the wall

Show me from behind the wall

Show me from behind the wall

Caetano Veloso ${ }^{2}$

No princípio eu era de carne e estava na terra. Começou assim. Não pensei em mim como rapariga nem como branca nem como rica ou pobre. Não pensei porque não era preciso. Eu era de carne e estava na terra. Isabela Figueiredo

\footnotetext{
${ }^{2}$ Tradução livre: Você não me conhece. Aposto que você nunca vai me conhecer. Você não me conhece de jeito nenhum. Sinto-me tão só. O mundo está girando lentamente. Não há nada que você possa me mostrar. De trás do muro. Mostre-me por detrás do muro. Mostre-me por detrás do muro. Mostre-me por detrás do muro.
} 


\title{
RESUMO
}

\author{
GEBRIM, Ana C. C. Psicanálise no front: a posição do analista e as marcas do trauma na \\ clínica com migrantes.
}

A partir de um fluxo acentuado de migrações para o Brasil, iniciado particularmente desde os anos 2010, novas populações, recém-chegadas (particularmente congoleses, angolanos, sírios e haitianos), passaram a interpelar a clínica psicanalítica com migrantes. Provenientes de realidades de violência extrema e condições precárias, as vivências dos sujeitos migrantes são marcadas por especificidades que vêm demandando novos questionamentos. Através de reflexões sobre a clínica com migrantes em instituições de acolhimento na cidade de São Paulo e na cidade de Paris, pretendemos sedimentar aportes teóricos para elaborar novas possibilidades de intervenção clínica, trabalhando a posição do analista e as vicissitudes desse encontro. Compreendendo o traumático como o sofrimento do sujeito diante de um acontecimento vivido como desastre, pensaremos nas possibilidades de fabricação de elementos clínicos de intervenção, assim como nas formas de sustentação de posições analíticas no encontro com esse sujeito migrante. Assim, debruçada sobre as experiências clínicas nas duas cidades supracitadas, tanto institucionalmente como em outras situações, a pesquisa pretende refletir sobre a dimensão do traumático, das diferenças de línguas e culturas, sobre as injunções institucionais e as questões raciais e coloniais presentes nas trajetórias de migrantes. Tomando como objeto, portanto, o encontro clínico entre migrante recém-chegado e o psicanalista, trataremos de refletir sobre as possibilidades tanto de intervenções clínicas em condições extremas, capazes de produzir ressignificações para o sujeito, como nas distintas posições possíveis para o analista, que frequentemente se encontra entre o excesso de implicação no sofrimento, de um lado e de outro, um distanciamento que produz efeitos de desmentido para o sujeito. Desse modo, pretendemos contribuir com elementos clínicos e teóricos para a prática de psicanálise em contextos extremos, particularmente com a população migrante e/ou em situação de refúgio.

Palavras-chave: Psicanálise, Migração, Refúgio, Trauma, Transferência. 


\section{RÉSUMÉ}

Depuis l'année 2010, un flux de nouvelles migrations vers le Brésil explique l'arrivée de populations de primo-arrivants (notamment des Congolais, Angolais, Syriens, Haïtiens). Ces nouvelles populations interrogent la clinique psychanalytique auprès des migrants. En effet, leur expérience de violence extrême et leur condition précaire les caractérisent et exigent un renouvellement des questionnements et des modalités d'intervention cliniques. A travers des réflexions sur la clinique avec des sujets migrants dans les institutions d'accueil de la ville de São Paulo, nous espérons contribuer à la réflexion sur de nouvelles possibilités d'intervention clinique. En partant de la notion de trauma comme une modalité de souffrance du sujet face à un événement vécu comme désastre, nous réfléchissons aux possibilités de conception de nouveaux éléments d'intervention clinique, ainsi qu'aux formes de positionnements analytiques dans la rencontre avec le migrant. Nous proposons, à un stade de notre réflexion, une comparaison avec la prise en charge des migrants à Paris, France, où l'arrivée récente de migrants a également exigé la mise en place de nouveaux dispositifs cliniques. Ainsi, à partir de cas cliniques menés dans les deux villes, cette recherche propose de qualifier le traumatisme, puis l'impact opéré dans la prise en charge par les langues et les cultures, enfin les injonctions institutionnelles et les questions raciales et coloniales présentes tout au long de la trajectoire des migrants. En prenant comme objet la rencontre clinique entre les migrants nouvellement arrivés et le psychanalyste, nous essayerons de réfléchir aux possibilités d'intervention clinique dans des conditions extrêmes, capables de produire de nouvelles significations pour le sujet. Nous montrerons en quoi les différents positionnements de l'analyste sont au centre de nouveaux dispositifs cliniques, puisque ce dernier peut être pris entre, d'une part, l'excès d'implication dans la souffrance du patient, et d'autre part, dans la distanciation nécessaire, qui produit alors des effets de désaveu pour le sujet. De cette manière, nous souhaitons contribuer à la pratique psychanalytique en contexte extrême, en particulier avec la population migrante et /ou exilée.

Mots-clefs : Psychanalyse, Migration, Refuge, Trauma, Transfert, 


\begin{abstract}
Starting from a steady flow of migrations to Brazil, initiated particularly since the year 2010 , new populations, just arrived, began to question the psychoanalytic clinic with migrants. Coming from realities of extreme violence and precarious conditions, the experiences of the migrant subjects are marked by specifics that have been demanding new questionings. Through reflections on the clinic with migrants in host institutions and shelters in the city of São Paulo and in the city of Paris, we intend to establish theoretical contributions to elaborate new possibilities of clinical intervention while working the analyst's position and the vicissitudes of this encounter. Understanding the traumatic as a modality of suffering of the subject in the face of an event experienced as a disaster, we will think about the possibilities of making clinical elements of intervention, as well as the forms of support of analytical positions in the encounter with this migrant subject. Thus, in the clinical experiences in the two cities mentioned above, both institutionally and in other situations, the research intends to reflect on the dimension of the traumatic, the differences of languages and cultures, on the institutional injunctions and the racial and colonial issues present in the trajectories of migrants. Taking into account, therefore, the clinical encounter between the newly arrived migrant and the analyst, we will try to reflect on the possibilities of both clinical interventions under extreme conditions, capable of producing re-significations for the subject, and in the different possible positions for the analyst, who often is between the excess of implication in the suffering on the one hand and, on the other, at a distance that produces denying effects for the subject. In this way, we intend to contribute with clinical and theoretical elements for the practice of psychoanalysis in extreme contexts, particularly with the migrant and / or refugee population.
\end{abstract}

Key words: Migration, Refuge, Trauma, Psychoanalysis, Transfer. 


\section{LISTA DE SIGLAS}

ONU Organização das Nações Unidas

ACNUR Alto Comissariado das Nações Unidas para os Refugiados

UNRWA Agência das Nações Unidas de Assistência aos Refugiados da Palestina no Próximo Oriente

CONARE Comitê Nacional para os Refugiados 


\section{Sumário}

PREFÁCIO

PREÂMBULO

INTRODUÇÃO

Parte I - Notícias do Front

Capítulo 1 - Considerações sobre as "Novas" migrações: as impressões do contexto

1.1 Imigrantes, migrantes, refugiados, exilados: tentativas de saída para um impasse

1.2 Política do muro, política da indiferença e a necropolítica: modos de governar indesejáveis

1.3 As "novas" migrações para o Brasil e as rotas Sul-Sul dos deslocamentos contemporâneos

Capítulo 2 - As clínicas e a escuta desterritorializada

2.1 Vivenciando a estrangeiridade na casa dos estrangeiros ou a escuta em uma casa de acolhida: cena 1

2.2 Entre necessidade e desejo, a escuta dos modos de resistência diante das retóricas da vítima e da temporalidade da urgência: cena 2

2.3 Notas inquietantes das andanças em campos de refugiados em Paris: cena 3 .........

2.4 Errâncias clínico-teóricas

102

Parte II - O instante do front

Capítulo 3 - Os estilhaçamentos do sujeito e alguns destinos

3.1 Cecil diante do desastre

3.2 Levy e o apequenamento pela culpa de estar vivo

3.3. Trauma e experiência

3.4 A vida que insiste: reflexões sobre a sobrevivência e as zonas de resistência..........

Capítulo 4 - Nas fronteiras entre línguas, culturas e papéis: o analista-coiote .......

4.1 Entre língua materna e a língua estrangeira: reflexões sobre a língua do analista. 
4.2 Cultura e desenraizamentos como problemáticas do deslocamento: o caso L. ........ 156

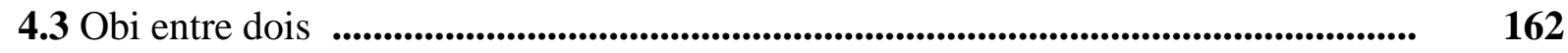

4.4 Elegibilidade, a questão da verdade e as injunções institucionais: o caso dos solicitantes de refúgio por orientação sexual ............................................................... 166

Parte III - Os mensageiros das más notícias .................................................................. 173

Capítulo 5 - $\mathrm{O}$ analista descobridor do próprio íntimo .......................................... 174

5.1 Uma certa “descoberta" tardia do racismo e o seu efeito de (d)enunciação ............. 178

5.2 Negritude, branquitude e violência política como analisadores na clínica ............... 183

5.3 O inconsciente colonial como o transtraumático: um lugar possível? ....................... $\quad \mathbf{1 8 8}$

CONCLUSÕES OU QUANDO OS INDESEJÁVEIS DESEJAM ........................... 201

REFERÊNCIAS BIBLIOGRÁFICAS _................................................................ 211

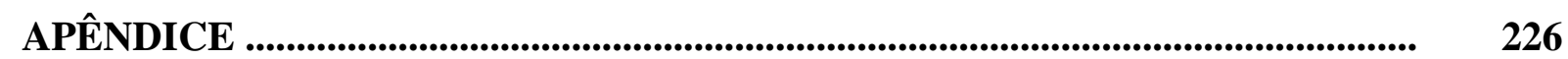

Anexo A - Autorização para realização da pesquisa .............................................................. 231

Anexo B - Termo de convênio para atividades de extensão entre a Missão Paz e o GrupoVeredas: Imigração e Psicanálise ............................................................................. 


\section{PREFÁCIO}

Na primeira vez em que morei fora da cidade em que nasci, tive uma experiência tão trivial quanto epifânica em um dia absolutamente comum. Só anos depois eu perceberia que em circunstâncias como aquela, uma escolha começava a tomar corpo. De onde surge um tema de investigação afinal? Dos três assentos que me cercavam em um banco de quatro pessoas no transporte público, nenhum era nascido naquela cidade, cada um originariamente de um país, cada um de uma cor, falando uma língua distinta. Naquele momento, percebi minha própria estrangeiridade, tal como um espelho, e de uma forma nova até então. Se ser estrangeiro é uma condição [perene ou efêmera], muitas vezes, determinada pelo espaço, podemos tomá-la como uma posição - uma perspectiva. A partir do instante em ocupei geograficamente o ângulo de estrangeira no espaço, foi tanto fascinada quanto angustiada, que tomei não só o tema de investigação dos oito anos que se seguiram, como a escolha da profissão que passei a ter desde então.

Aqui, antes de tudo, é importante pontuar que essa não foi nem de longe uma vivência de violência. Franz Fanon narra uma situação semelhante, mas a partir de uma experiência bastante distinta de externalidade. Certo dia, no metrô de Paris, um menino branco lhe apontou e disse: "Tiens, un nègre"”. Ali, Fanon conta ter se sentido desamparado e exposto ao mundo em uma experiência que lhe negava a vida interior (GORDON, 2015). Nossas experiências são distintas e isso também será tratado ao longo da pesquisa de modo a discutir de que formas, perspectivas e lugares diferentes ocupados nos discursos é possível sustentar a escuta com um outro. Dentro do meu vagão de metrô, minha vivência de externalidade não incidiu como negação de vida interior, talvez porque a branquitude que marca a experiência do meu corpo amordace qualquer possibilidade semelhante à da exclusão do corpo negro no laço social colonizado pela cultura ocidental. Quase como se a branquitude impressa no corpo operasse como um laissez-passer ${ }^{4}$ de um passaporte diplomático em qualquer país do mundo para um viajante. No entanto, de algum modo, essa minha vivência soft de externalidade foi preponderante para anos depois, eu mesma pensar nas condições de escuta e compartilhamento de vivências e de lugares distintos no laço.

\footnotetext{
3 “Olha só, um negro".

${ }^{4}$ Não sem desconfiança pelos traços, rastros e pegadas de latinidades e arabeidades.
} 
A aventura de empreender uma pesquisa de doutoramento persegue o mesmo rastro de uma pergunta que se reatualiza em cada encontro clínico: quais as possibilidades de compartilhamento com um outro? Entre o longe e o perto demais, o mergulho em uma nova abordagem que se concentra na prática, pela pesquisa, me pareceu um recurso tanto possível quanto necessário de elaboração.

Em 2011, na França, na pesquisa de mestrado (Univesidade Paris Diderot), investiguei a problemática do duplo pertencimento de migrantes de antigas colônias francesas que haviam se assimilado profundamente à cultura colonizadora. Considerados percursos bem-sucedidos, me deparei com pessoas literalmente premiadas pelo governo francês por suas trajetórias de integração de sucesso aos valores universalistas do país. A partir dessas mesmas trajetórias, foi possível constatar que a homofonia da palavra francesa para prêmio - prix, que significa ao mesmo tempo preço, - também incidia em uma dupla enunciação contraditória (HASSOUN, 1998) na forma como os percursos de integração tinham ocorrido. Na pesquisa, foi possível levar em conta alguns dos custos empreendidos na renúncia ao pertencimento originário pela adesão aos principais símbolos da cultura outrora colonizadora, assim como revelar algumas das saídas e estratégias de resistência de cada sujeito a esses mesmos discursos (GEBRIM, 2012).

Motivada, a princípio, por essas questões, no ano de 2013, no Brasil, comecei a atender semanalmente pessoas migrantes e refugiadas recém-chegadas na cidade de São Paulo, no abrigo Casa do Migrante, ano em que passei a integrar o grupo de extensão cultural da Universidade de São Paulo, Migração e Cultura, e que mais recentemente veio a se chamar Grupo Veredas: psicanálise e imigração. Coordenado desde 2000 pela Professora Doutora Miriam Debieux Rosa, o grupo sustenta uma proposta de intervenção clínica em instituições relacionadas à população migrante. Em 2013, éramos cerca de oito analistas em formação que nos dividíamos em idas em duplas ou trios, em três distintos dias da semana, durante duas horas, para realizar nossa intervenção clínica com os moradores do abrigo. Em outro dia da semana, fazíamos o trabalho de supervisão com a Profa. Miriam Debieux Rosa, com Cristina Rocha Dias, Leonel Braga e Ilana Mountian. Trava-se de um trabalho sem remuneração, e, portanto, voluntário, e que nos engajava intensamente em duas noites por semana.

Em 2014, a convite de Taeco Toma Carignato, passei a integrar também voluntariamente a equipe de Saúde Mental do Centro de Referência para Refugiados da Caritas Arquidiocesana de São Paulo. Um ano depois, passei a atuar como psicoterapeuta da 
mesma instituição. Ali, durante dois anos, junto a outras três colegas, Flavia Gleich, Luciana Carvalho e Ana Cristina Berntz, tivemos o desafio e a oportunidade de gestar, com bastante autonomia e ousadia, os modelos de uma nova equipe clínica com sujeitos refugiados e solicitantes de refúgio em São Paulo. Também a partir de 2015, deixei de atender semanalmente no abrigo da Casa do Migrante, e passei a supervisionar o Grupo Veredas, em parceria com Pedro Seincman, um trabalho semanal de supervisão a um grupo de mais de dez pessoas que atende tanto na Casa do Migrante como em outros espaços voltados para a população migrante na cidade de São Paulo.

No âmbito do presente doutorado (IP - USP), a tese foi inscrita em uma cotutela com a universidade francesa INALCO (Institut National des Langues et Civilisations Orientales), no seio do laboratório CESSMA (Centre d'études en sciences sociales sur les mondes africains, américains et asiatiques - núcleo de pesquisa junto com INALCO- Paris Diderot IRD) e sob coorientação da Professora Doutora Marie-Caroline Saglio-Yatzimirsky, realizei um período de estágio em Paris por seis meses, entre 2017 e 2018. Nessa ocasião, pude não só frequentar diversos seminários, conferências e grupos de discussão e trabalho sobre o tema da pesquisa, como incursões em alguns contextos atravessados pela problemática migratória. Assim, durante alguns meses, visitei um centro de acolhida para migrantes recém-chegados na cidade de Paris, assim como acampamentos a céu-aberto de pessoas instaladas em diversas partes da cidade. Consistiam em idas semanais, guiadas pela Profa. Marie-Caroline SaglioYatzimirsky e seu grupo de pesquisa LIMINAL sobre as interações entre exilados e atores institucionais e associativos ${ }^{5}$, em que era proposto, através de encontros, trocas e conversas com as pessoas, compreender o que se passava nesses contextos.

A pesquisa parte, portanto, da experiência nesses contextos clínicos de atendimento, no abrigo Casa do Migrante e no Centro de Referência para Refugiados da Caritas e nas andanças pelos campos de refugiados em Paris. Fora dos consultórios, trata-se de intervenções que convocam estratégias criativas e não convencionais predominantemente por duas razões: de um lado, porque trabalhamos com sujeitos vivendo condições extremas (precariedade de recursos, pessoas recém-chegadas de trajetórias árduas de deslocamento, muitas vezes impelidos por razões de violência e perseguição de seus países de origem, desterritorializados de suas referências familiares, e em grave sofrimento psíquico), de outro, por sustentarmos a

\footnotetext{
${ }^{5}$ Mais informações sobre LIMINAL: https://liminal.hypotheses.org
} 
proposta de uma intervenção que desloca o analista de seu próprio setting tradicional lançando-o na circulação e apropriação de outros espaços e formas de movimentação.

Debruçada sobre as trajetórias de sujeitos desterritorializados de seus países de origem ou na clínica com pessoas em situação de migração hoje, me vejo constantemente diante de elementos específicos e gerais daquilo que tomamos como a prática da clínica psicanalítica. É fundamental sublinhar que toda a investigação surge do campo - da intervenção clínica em psicanálise - e de tudo o que essa prática suscitou, dos desafios, dos limites, dos erros, dos acertos e das questões que permanecem em aberto. E, sobretudo, da necessidade de fabricar, a partir de minha própria experiência, elementos clínicos de intervenção e reflexão a partir de um campo que inclui de forma permanente a fronteira com diversas problemáticas. 


\section{PREÂMBULO}

Em 2014, uma situação salta aos olhos dentre as notícias diárias: no campo de refugiados de Calais, na França, até então conhecido controversamente como Jungle, uma pequena organização humanitária decidira oferecer a um grupo de refugiados recém-chegados ao acampamento uma refeição tida como típica dessa mesma região. Os funcionários passaram o dia preparando a refeição com esmero, incluindo todos os condimentos e ingredientes da receita. Depois de servirem as "quentinhas", os membros da organização aguardavam satisfeitos e ansiosos a boa reação diante da iniciativa caridosa, quando foram tomados por uma perplexidade: quase todas elas tinham sido atiradas ao mar. Ao indagarem o porquê de tamanha desfeita, muito dos refugiados não tardaram em dizer que a marmita estava intragável, havia condimentos demais. 


\title{
INTRODUÇÃO
}

\author{
O estrangeiro é, em primeiro lugar, \\ o significante de um espaço desconhecido
}

(Radmila Zygouris)

Um analista na linha de frente, instalado na fronteira, no instante do front. Partimos daí em nossa investigação que toma a própria prática clínica da ana-lista como reflexão. Do encontro entre sujeitos migrantes e analista, indagamo-nos sobre as possibilidades de intervenção nos contextos extremos. Como extremo, compreendemos duas dimensões: a de uma realidade social de violência, precariedade e, portanto, grave violação de direitos humanos, e, concomitantemente, a de um contexto de profundo sofrimento psíquico dos sujeitos. Isto é, tomamos as crises psíquicas de irrupção da angústia, as vivências do traumático, as questões linguísticas e culturais, as injunções institucionais e outras problemáticas da desterritorialização nas trajetórias dos sujeitos migrantes de forma complementar à compreensão das incidências das políticas, dos discursos hegemônicos de repressão e exclusão e dos modos de aniquilação das populações mais pobres em trânsito.

O front a que nos referimos é o que se instala diante do tempo do traumático, reatualizado no vínculo com o analista e literalizado em uma memória que não se esquece de sujeitos marcados pela violência e pelas condições extremadas de necessidade. Assim, nos perguntamos sobre as possibilidades de escuta e intervenção no front de sujeitos que vivenciam diariamente a violência policial, sujeitos com fome ou com frio, invadidos por seus torturadores nos pesadelos ou flash-backs, e marcados por violências coloniais que seguem se reatualizando no presente. Desse modo, nos indagamos sobre as possibilidades de fabricação clínica nesses contextos. Isto é, desde o front como pensar o traumatismo na transferência?

Partindo da compreensão do traumático como uma modalidade de sofrimento do sujeito diante de um acontecimento vivido como desastre, pensaremos nas possibilidades de fabricação de elementos clínicos de intervenção, assim como nas formas de sustentação de posições analíticas no encontro com esse sujeito migrante recém-chegado de diversas situações. Frente a contexto extremos, duas respostas se apresentam com frequência nas intervenções clínicas: de um lado uma hiper-implicação do analista nos casos que mobilizam 
muitos afetos, de outro o distanciamento como modo de proteção. Se falamos em front, se falamos da guerra reatualizada no vínculo, como deve o analista se instrumentalizar, como se posicionar, como escutar, como se proteger da super exposição, quais os riscos, quais elementos devem ser incluídos, quais seus limites e possibilidades? Ou ainda, como pensar na transferência em um contexto do front?

Ambas as saídas, a hiper-implicação e o distanciamento excessivo parecem ser modos restritos de intervenção e que tendem tanto reduzir as possibilidades do analista, como, com frequência, produzir efeitos de desmentido nas vivências dos sujeitos atendidos. Se as intervenções em contextos de urgência mobilizam afetos, emergem na mesma medida tanto os riscos como os pontos cegos para o analista. Perseguindo o rastro de uma investigação que se pergunta sobre as possibilidades de escuta e intervenção nos contextos extremos, parto da minha própria experiência, dos efeitos no meu próprio corpo, das impressões nos sonhos, na angústia, e todas as modalidades de estranhamento para pensar as fabricações do clínico.

Diante desses extremos que parecem se radicalizar frente ao sujeito migrante, podemos também pensar nas vicissitudes de todo encontro clínico, e aqui estrangeiro e migrante são, igualmente, metáforas para se pensar nas possibilidades e limites de todo encontro que também produz desencontros. Sendo assim, perante um contexto que também interpela as extremidades do próprio analista, nos perguntamos sobre como posicionar a escuta - ouvido - corpo - lugar? Quais os efeitos para o analista? E, finalmente, como fazer psicanálise no front?

Partimos, na pesquisa, da clínica psicanalítica de intervenção nos diferentes contextos do campo. No entanto, front também nos remete à fronteira, lugar de conflito e confluência, permeabilidade e barreira, atravessamentos e impedimentos. Migração, nesse sentido, é um tema de interseção e fronteira na medida em que que convoca permanentemente o cruzamento entre vários campos de conhecimento e atuação. Tema da psicologia, da geografia, da antropologia, da sociologia, da assistência, do direito, das ciências políticas, aqui optamos pela perspectiva que compreende a dimensão psíquica das modalidades subjetivas de deslocamento entre espaços, culturas e línguas diante da dimensão física do deslocamento geográfico. Desse modo, tomar a experiência de sujeitos migrantes através da escuta psicanalítica faz com que tenhamos que incluir de forma contínua dois grandes campos: as indagações e atravessamentos sócio-políticos do mundo externo, e os desdobramentos e 
vicissitudes subjetivos sedimentados no mundo interno. Diante disso, um objeto clínico de pesquisa: o encontro entre dois sujeito, analista e migrante para pensar a relação com o outro.

Pensamos na migração hoje como um modo de existência. Como modalidades de resistência e insistência, sustentamos a perspectiva de uma clínica na direção do desejo, das potencialidades de reinvenções e recriações identitárias dos sujeitos a partir da circulação e instalação nos mais diversos espaços. Nesse sentido, circulação e instalação, ou simplesmente migração, são não somente direitos humanos elementares, mas igualmente modos potentes e criativos de existência e resistência frente aos discursos sociais dominantes que vedam a condição de sujeito (ROSA, 2012a) às populações mais pobre em trânsito pelo globo. Seguindo essa direção, nos vemos frequentemente tendo que lançar mão de estratégias igualmente criativas para pensar em intervenções clínicas nesses contextos.

Assim, em uma investigação que trata sobre a posição do analista em realidades extremas de migração humana, pensamos em intervenções que sustentem um posicionamento implicado também em relação aos discursos hegemônicos que marcam as vivências subjetivas de inúmeras violências. Como dissemos, mais do que garantir o direito de migrar, pensamos nas diferentes dimensões subjetivas de circulação e instalação, e sobretudo nas possibilidades tanto de aportar e ter condições de fazer do exílio movimento propulsor de desejo, como das possibilidades de circulação que faça do duplo pertencimento também um duplo lugar de enunciação. Pensamos, assim, igualmente, nos modos de desalienação do analista aos mesmos discursos que promovem violência e restrição humana.

Desse modo, é partindo de experiências clínicas aqui relatadas na forma de vinhetas, casos clínicos e diários de campo, que pensamos nos modos de fabricação do clínico. Em suma, são das minhas próprias fabricações desde o front que as articulações são trabalhadas, tanto nas intervenções relatadas, quanto na composição de um glossário próprio, lançado mão para me referir à mesma prática. Permanentemente ancoradas em conceitos e autores, as soluções conceituais encontradas forjam noções a partir de neologismos ou adaptações dos mesmos, de modo a responderem à realidade tratada e às fabricações do clínico.

A partir do fluxo que chamamos de "novas" migrações para o Brasil (SAGLIOYATZIMIRSKY; GEBRIM, 2017), mas aliado também ao aumento das migrações em condição de violência em todo o mundo, nos perguntamos ao longo da pesquisa até que ponto esses fenômenos vêm interpelando as práticas clínicas junto à essa mesma população. Isto é, em que medida os novos fluxos migratórios para o Brasil, igualmente aliado às reflexões 
sobre os novos fluxos de chegada também no contexto europeu, caracterizam diferentes abordagens e reflexões clínicas com pessoas em situação de migração? Ou ainda, haveria elementos preponderantes em relação às novas chegadas que convocam novas reflexões, ou aspectos clínicos a serem levados em conta? Enfim, até que ponto é possível pensar que esses novos fluxos migratórios culminaram por interpelar ou suscitar reflexões sobre estratégias e intervenções clínicas de forma geral?

A dimensão sociológica dos fluxos migratórios na Europa nos leva a compreender, a título de exemplo, que na França o nascimento e desenvolvimento da etnopsiquiatria, e, em particular, os trabalhos de Tobie Nathan e suas consultas no Hospital de Avicenne nos anos 1980, eram dirigidos, sobretudo, a migrantes vindo do Maghreb e da África do Oeste, em um contexto pós-colonial. A partir das migrações massivas para a Europa nas últimas décadas, provenientes de outros contextos, assim como a chegada de populações refugiadas da Ásia do Sul (Tamouls, Bengalis), ou do Oriente Médio, esse mesmo dispositivo proposto anteriormente demonstrou alguns limites. Atualmente, o medo pelo radicalismo islâmico e o terrorismo após os eventos ${ }^{6}$ de 2015, na França, também acompanham a chamada "crise" migratória e a forma como as populações em trânsito são recebidas e tratadas. Nesse mesmo sentido, pretendemos colocar em questão, na realidade brasileira, as modalidades dos dispositivos clínicos em face do novo fluxo migratório.

Cabe questionar, assim, o que essas novas migrações vêm dizer para a clínica e o que elas despertam também no próprio clínico. Uma tese, portanto, sobre a transferência da analista ou então, uma reflexão sobre a minha prática, sobre a minha própria clínica imersa nesse contexto e desde as minhas experiências. Na esteira de todos esses questionamentos, nos perguntamos, finalmente, como a clínica vai se endereçar a essas pessoas, como escutálas, e a partir de qual lugar? Essas são algumas das questões centrais trabalhadas ao longo da pesquisa. Trata-se das formas de pensar em uma escuta ancorada da dimensão sócio-política do sofrimento (ROSA, 2016), da produção social do deslocamento, das possibilidades de restituição do laço social e da politização do acontecimento vivenciado pelo sujeito. Assim, de forma geral, nos interessamos menos nas especificidades da clínica das migrações e mais

\footnotetext{
${ }^{6}$ Aqui nos referimos aos trágicos eventos na França no ano de 2015, todos reivindicados pelo Estado Islâmico. Particularmente o de 7 janeiro na ocasião do ataque ao jornal Charlie Hebdo, com dezenas de mortos e feridos, e o de 13 de novembro em diversos pontos da cidade de Paris, em que centenas de pessoas foram mortas e gravemente feridas.
} 
às possibilidades de sustentar um dispositivo clínico a partir de uma escuta ancorada no sofrimento, que é humano e compartilhado pelas vicissitudes da experiência.

O campo de pesquisa parte tanto de casos clínicos, como das análises e reflexões nos diários clínicos realizados durante as intervenções e incursões. Igualmente, é importante sublinhar que, inscrita em uma cotutela, em diversos momentos, a pesquisa realiza o deslizamento entre reflexões sobre a realidade brasileira e a realidade francesa no que se refere ao contexto dos deslocamentos atuais. Das experiências clínicas em São Paulo, e a partir das imersões nas cidades de Paris e Beirute, foi possível acumular uma série de notas de observações, reflexões inquietantes e trocas remarcáveis que enriqueceram a compreensão da realidade das migrações no contexto atual.

Diante desses vários campos, há de se levar em conta, também, os constantes deslocamentos empregados durante a escrita. Portanto, as noções de deslocamento e desterritorialização operam como pontos de partida e sustentação da própria posição da pesquisadora e analista nesse contexto, além de serem também recursos centrais da escolha de uma pesquisa inscrita em uma dupla titulação de psicologia clínica e antropologia, e consequentemente, entre psicanálise e ciências sociais, mas também entre a clínica e a teoria. Pensar a clínica diante do fenômeno das migrações contemporâneas é um tema que pressupõe a complementariedade de duas grandes áreas: a perspectiva psicanalítica e sua teoria sobre o sujeito, e a dimensão sociológica dos atravessamentos político-sociais. Como recurso permanente, utiliza-se autores inscritos em diferentes escolas e linhas teóricas, e, igualmente, deslocamentos constantes entre a primeira pessoa do singular - em todos os momentos que a presença da analista e sua reflexão é corporificada - e a primeira pessoa do plural - quanto às reflexões propostas.

Deslocamento é tanto um conceito da psicanálise como um substantivo que define a ação de mudar de lugar. Nesse sentido, tomamos a palavra nessa dupla acepção para tratar o fenômeno físico que se põe em marcha através da circulação, pois nos debruçamos sobre sujeitos inscritos em um fenômeno maior de deslocamentos humanos, e concomitantemente, alguns dos desdobramentos dos deslocamentos psíquicos desse mesmo movimento. Deslocamento [Verschiebung], na teoria freudiana, é relativo à uma formação inconsciente em que "um acento, um interesse ou uma intensidade" (LAPLANCHE \& PONTALIS, 1967, p.110) de uma representação constantemente se desligue e se religue a outras representações em uma cadeia associativa. Na Interpretação dos Sonhos, Freud (1900) define o 
deslocamento como um processo psíquico próprio da formação dos sonhos, que como tal favorece o processo de condensação, ou seja, a figurabilidade no sonho é facilitada pelo deslocamento na medida em que há a passagem entre a representação abstrata a uma outra que pode ser visualizada (LAPLANCHE; PONTALIS, 1967). Por conseguinte, refere-se a um processo psíquico de deslizamento associativo, em que elementos primários latentes se deslocam para representações secundárias manifestas. Deslocamento é, então, um processo tanto físico de mudança geográfica, como um recurso subjetivo de representar as próprias formações inconscientes primárias em representações figuráveis. Nesse sentido, pensamos nas formas pelas quais os deslocamentos geográficos também impelem deslocamentos psíquicos. Ou ainda, na esteira dos deslocamentos geográficos, tratamos de compreender os deslocamentos psíquicos de novas representações dos sujeitos em novos espaços.

Através da ideia de deslocamento ${ }^{7}$ também diversas metáforas se apresentam como recurso possível de reflexão: fronteiras, porto, âncora, bússola, coiote, travessia, ponte, entre outras que foram brotando à medida em que a prática clínica demandava tanto imaginação como construção. Igualmente, podemos pensar que psicanálise e sociedade compartilham vocabulário comum se pensarmos em: conflito, repressão, censura, perseguição, defesa, fronteiras, deslocamento, escolha e desejo. Isto é, todos os momentos que em estamos confrontados com o cruzamento entre os fenômenos do mundo externo e os psíquicos, do mundo interno. Assim, partimos também da compreensão do cruzamento daquilo que alguns autores consideram como a História com h maiúsculo, dos grandes acontecimentos sociais, e a história com h minúsculo, da trama singular de cada um, para compreender a dimensão de experiência dos sujeitos nesse contexto.

Apenas como um recurso elucidativo, cabe delinear, portanto, que trazemos à discussão duas perspectivas que são confluentes, (H)istória e (h)istória. Compreendemos que toda dimensão histórica, seja ela singular ou coletiva, é transversal entre as dimensões individuais e sociais, mas pontuar essa nuance nos ajuda a levar em conta algumas das bordas sobre a incidência dos grandes acontecimentos na experiência singular dos sujeitos e alguns de seus desdobramentos. Assim, juntamente com Caterina Koltai (1997) e Davoine e Gaudillière (2006) utilizamo-nos desse recurso para tratar precisamente da conjunção permanente entre a história individual e a história coletiva em sujeitos que experenciaram

\footnotetext{
${ }^{7}$ Laplanche, Pontalis (1967) e Roudinesco (1997) apontam como na obra lacaniana deslocamento e condensação foram tomados respectivamente como metonímia e metáfora na lógica de compreensão do inconsciente estruturado como uma linguagem.
} 
situações extremas de violência social. Nos debruçamos, assim, justamente sobre a perspectiva do encontro dessas duas dimensões na experiência dos sujeitos.

Com frequência, também nos servimos do termo desterritorialização ${ }^{8}$ como metáfora da geografia para pensar nos desdobramentos ou no próprio ato de deixar o próprio lugar. Aqui, é importante sublinhar uma nuance entre deslocamento e desterritorialização. Se deslocamento define a ação de mudar de lugar - portanto, o movimento ou o deslizamento entre dois, desterritorialização aponta para a ação de deixar o lugar primeiro. Desterritorializadas, nesse caso, são tanto as pessoas fora dos lugares originários, quanto os processos ou posições em que se encontram alheios ou fora de algum lugar primeiro. De tal modo, pensamos concomitantemente no fenômeno físico e geográfico de desterritorialização pelas migrações, como nos processos psíquicos acerca da posição desterritorializada de algum lugar outro.

Tendo em vista as noções de deslocamento e desterritorialização, é importante situar ainda mais alguns pontos no que se refere ao lugar do analista nas intervenções nesses contextos. Se, como vimos, na clínica com sujeitos em deslocamento geográfico e desterritorializados de seus lugares de origem, somos convocados a pensar em estratégias não convencionais das intervenções, partimos da compreensão do lugar do analista como esse instalado precisamente no sítio do estrangeiro (KOLTAI, 1997). Se o processo analítico se configura como aquele que cria condições para que o sujeito se depare com um outro em si sujeito marcado pela dimensão inconsciente, trata-se do encontro com um estranho em si mesmo - Caterina Koltai (1997) nos oferece a ideia do analista como aquele justamente nessa dimensão outra, ancorado assim, no lugar ou no sítio do estrangeiro.

Partindo desse princípio, pensamos tanto na oferta de estrangeiridade do analista enquanto condição de escuta, como em seu lugar de estrangeiro como posição possível para poder criar condições de compartilhamento e sustentação da própria intervenção. Nesse sentido, ao longo da pesquisa, traçaremos alguns aspectos que se referem às reflexões sobre a sustentação de uma escuta, às possibilidades de intervenção e compartilhamento no encontro clínico, e sobre a posição do analista nesse contexto. Movimento permanente, portanto, entre

\footnotetext{
${ }^{8}$ Desterritorialização também é um conceito forjado por Deleuze e Guattari (1997) a partir da geografia cultural para pensar na ruptura de territorialidade entre uma sociedade e um território originário. Pensado como uma linha de fuga, a desterritorialização, para os autores, se refere ao movimento de abandonar o território original. Nesse sentido, desterritorialização e reterritorialização são processos conjuntos de agenciamento dos corpos.
} 
sujeitos desterritorializados e em deslocamento, como vimos, e posição do analista em permanente deslocamento das intervenções convencionais e desterritorializado de seus lugares de origem. Desse modo, tomamos a noção de estrangeiridade tanto como a condição experenciada pelo estrangeiro, mas também como sentimento de estranheza nas vivências de externalidade. É, portanto, dessa dupla acepção também que partimos para pensar na estangeiridade do analista como condição de escuta e como possibilidade de posicionamento.

Assim, diante de sujeitos desterritorializados de seus países de origem, propomos a desterritorialização - que é também própria da posição do analista, mas aqui a pensamos como sustentação possível da escuta. A partir disso, muitas perguntas se colocam em torno dos desdobramentos desse corpo em cena. Pensar a clínica com migrantes hoje é tema de uma pesquisa que, a partir das próprias intervenções, pretende também refletir - entre as especificidades e universalidades do campo, sobre a posição do analista.

Por migrantes abordamos as populações em êxodo ao redor do globo atualmente. Populações predominantemente pobres e dos países do Sul, trata-se de pessoas que se deslocam permanentemente em busca de melhores condições de vida, mas igualmente pessoas rechaçadas, impedidas de circular e de se instalar, exploradas e segregadas pelas principais políticas migratórias dos países mais ricos. No primeiro capítulo da tese, na esteira das notícias do front, iremos abordar o contexto em que a pesquisa está inscrita. Assim, em um primeiro momento, trataremos não só dos principais números e contextos dos fluxos de migrações da atualidade como alguns dos termos empregados para se referir à essas mesmas populações.

Migrantes, refugiados, imigrantes econômicos, exilados, a partir da definição desses termos tanto pelas leis internacionais e como pelas reflexões e problematizações de alguns autores, trataremos, igualmente, dos desdobramentos da utilização desses termos na produção da figura do migrante hoje como figura indesejável. Através dessa discussão, pretendemos apontar algumas das saídas diante daquilo que consideramos um excesso de nomeações que culminam por objetificar ou invisibilizar as reais condições da experiência vivida pelos sujeitos, assim como nos posicionar diante dessas terminologias definindo quais termos serão empregados ao longo da pesquisa e em quais situações.

Assim, em vias de contextualizar o campo e pensar nos principais discursos em torno dos sujeitos em situação de migração, trataremos das principais políticas lançadas mão pelos países mais ricos, predominantemente abordando alguns exemplos do contexto europeu, 
diante das novas chegadas de pessoas. Aqui pensamos nos modos de governabilidade e gestão de sujeitos migrantes novamente tidos como indesejáveis nos países mais desenvolvidos. A partir de três grandes discursos, abordaremos, de forma geral, o modo pelo qual as principais políticas migratórias têm sido concebidas na atualidade. Assim, chamaremos de política do muro, política da indiferença e necropolítica as três modalidades intrincadas de governabilidade e produção em torno da figura do migrante. Ainda nesse capítulo, discutiremos aspectos sócio-políticos da realidade das "novas" migrações para o Brasil e o contexto de acolhimento e integração na cidade de São Paulo, predominantemente a partir da descrição das duas instituições em que a pesquisa estava inserida, a Casa do Migrante e a Caritas de São Paulo.

No segundo capítulo, ainda na esteira das notícias do front, contextualizaremos o campo clínico da pesquisa relatando cada espaço de intervenção a partir da figura de três cenas, são elas: a escuta no abrigo Casa do Migrante, no centro de São Paulo, a intervenção no seio da equipe de Saúde Mental do Centro de Referência para Refugiados da Caritas Arquidiocesana de São Paulo, e a experiência nos campos de refugiados na cidade de Paris. A partir dessas três cenas, abordaremos através de vinhetas, casos clínicos e diários de campo, aspectos sobre a intervenção em contextos extremos. Situadas em contextos institucionais distintos, grupos e equipes diferentes e mesmo cidades ou países, tentaremos abordar elementos que configurem um dispositivo comum, isto é, a possibilidade de traçar um conjunto de práticas que digam respeito ao posicionamento do analista nesses contextos.

$\mathrm{O}$ intento de configurar as três experiências em torno da reflexão sobre um mesmo dispositivo vai de encontro com a forma que a pesquisa está construída: à medida em que as análises clínicas são feitas, os diferentes casos atendidos nos distintos contextos estão entrelaçados e misturados sem linearidade. Isto é, em cada situação clínica narrada ao longo do texto, não anunciamos particularmente em qual contexto institucional o caso foi atendido, pois debruçados também sobre a noção de dispositivo, nos interessamos em refletir sobre o posicionamento do analista e os diferentes casos clínicos dos dispositivos propostos.

Por dispositivo entendemos um determinado ordenamento de formas de atuação em um contexto. Isto é, pensar em um dispositivo clínico é partir da noção de um conjunto de práticas que delimita certo posicionamento diante da clínica. Aqui, tomamos clínica na acepção desde sua origem etimológica como kliniké, que como sublinha Fabienne Hanique, partindo da noção do médico recostado ao "pé do leito" marca-se precisamente o momento 
em que "o médico não se interessa somente pelo corpo ou pelos órgãos defeituosos, mas pelo paciente mesmo e o que ele tem a dizer sobre sua doença" (HANIQUE, 2009, p. 45). Trata-se, portanto, de uma postura ancorada em uma abordagem singular, a de estar debruçado justamente sobre as vivências do sujeito. Falar de dispositivo clínico, portanto, se refere à tentativa de abordar um mesmo regime de práticas utilizadas em um contexto, no mesmo sentido em que Deleuze (1990) define que: "cada dispositivo tem seu regime de luz, maneira pela qual a luz cai, se esfumaça, se expande, distribuindo o visível e o invisível, fazendo nascer ou desaparecer um objeto que não existe sem ela" (DELEUZE, 1990, p.4). Assim, dispositivo configura os modos de existir de certa coisa, ou dos ordenamentos pelos quais vemos os contornos que delimitam uma prática e um posicionamento comum diante da clínica.

Para abordar o conjunto de práticas que configuram nosso dispositivo, trabalharemos ao longo do texto aspectos do que consideramos como alguns dos norteadores ou dos direcionamentos da intervenção clínica nesses contextos. Aqui, pensamos nos norteadores ou direcionamentos tais como uma bússola - que como um instrumento de navegação aponta as linhas de horizonte e as extremidades dos polos, permitindo tanto nos orientar como traçar direções - e não como uma estrada ou um caminho já estabelecido a ser trilhado. Pretendemos, portanto, nos aprofundar na reflexão sobre a prática, com vistas a sedimentar aportes para novas intervenções nesse contexto.

No terceiro capítulo da tese, no instante do front, trataremos dos estilhaçamentos dos sujeitos pela dimensão do trauma através de dois casos clínicos. Discutindo a noção de trauma e experiência, compreendemos o traumático como o sofrimento do sujeito diante de um acontecimento que incide como desastre. Para desenvolver essa discussão presente nas intervenções nos contextos de front, nos servimos de diferentes autores inscritos em distintas referências e tradições teóricas para nos ancorar diante de alguns dilemas clínicos apresentados.

Com Ferenczi (1932) pensamos tanto a noção de trauma enquanto estilhaçamento psíquico como nas possibilidades de intervenções analíticas que não produzam mais danos. Com Davoine e Gaudillière (2006), discutimos a noção de enlouquecimento do sujeito diante da ruptura do laço pela vivência do traumático e nas intervenções do analista instalado no tempo do front. Com Debieux Rosa (2012) pensamos na escuta do sofrimento sócio-político e a posição implicada do analista diante dos discursos hegemônicos que produzem violência. 
Com Saglio-Yatzimirski (2018), pensamos na diferenciação das dimensões do traumático acidental e intencional para pensar nas intervenções analíticas a partir de uma presença desejante. Com Fassin e Retchman (2007) discutimos o alastramento da noção de trauma no campo humanitário e seus efeitos de despolitização do sofrimento e esvaziamento da experiência. Finalmente, com Nathalie Zaltzman (1994), a partir de seu conceito de pulsão anarquista, pensaremos nas possiblidades de escuta que vise restituir o laço e a dimensão política da experiência dos sujeitos.

No quarto capítulo da tese, a partir da problemática das diferentes línguas de atendimento, das distintas culturas dos sujeitos atendidos, e de todas as injunções institucionais presentes na trajetória de recém-chegados, discutiremos através de dois casos clínicos e algumas vinhetas, as possibilidades de intervenção do analista e de fabricação de elementos clínicos. Línguas, culturas e papéis, pensaremos na posição de um analista-coiote nos contextos de fronteira que vise favorecer tanto a circulação quanto a instalação dos sujeitos em suas trajetórias de deslocamento.

No quinto e último capítulo, a partir da figura dos mensageiros das más notícias, trabalharemos aspectos do que as "novas" migrações vêm dizer e interpelar a clínica psicanalítica e o próprio analista. Assim, tomaremos negritude, branquitude e violência política como analisadores na clínica para pensar nas possibilidades de compartilhamento e escuta no encontro entre analista e analisando. Isto é, compreendemos que a chegada de novas pessoas vem reatualizar elementos tanto fundantes quanto não elaborados do imaginário histórico que atravessa a clínica. Nesse sentido, pensaremos nas modalidades de endereçamento e posicionamento do analista nesses contextos que favoreçam a escuta política das pessoas migrantes em sofrimento.

Com esse trabalho, portanto, espero contribuir para reflexões, questionamentos e inquietações a respeito das possibilidades de intervenções clínicas em psicanálise com pessoas em situação de migração na atualidade, de modo a discutir, igualmente, os atravessamentos e vicissitudes políticas do sofrimento e sua escuta. 
Parte I

Notícias do Front 


\section{Capítulo 1}

\section{Considerações sobre as "Novas" migrações: as impressões do contexto}

Abordando-se apenas circulações e fluxos, gestão de entradas ou de controle dos excessos, não apenas se despolitiza a questão dos Sem-Estado, mas se desumaniza $a^{9}$. (Michel Agier)

A partir de 2015, os grandes meios de comunicação em massa, assim como alguns discursos políticos, passaram a falar em uma "crise" migratória vivida predominantemente pela Europa. A noção de crise vem sendo profundamente problematizada por especialistas e ativistas no contexto diante dos números, que evidenciaram não só o baixo contingente recebido pelo continente europeu, proporcionalmente ao território, como o fato de que ao longo do tempo sempre houve diversos fluxos humanos em movimento. Igualmente, em toda sua história, o Brasil foi destino de distintos fluxos migratórios, externos e internos, continentais e intercontinentais. Gostaríamos, no entanto, de sublinhar um período recente para o recorte da pesquisa, e adotamos o termo "novas" migrações para abordar determinado fluxo de pessoas, sendo as aspas reveladoras da complexidade da questão.

A presente pesquisa parte predominantemente do encontro com migrantes recémchegados ou recém-instalados na cidade de São Paulo, entre os anos de 2012 a 2017, período que foi marcado pelo aumento substancial de novos fluxos migratórios para o país, oriundo de uma rota Sul-Sul, e pelo aumento de solicitações de refúgio em diversas regiões do mundo. Paralelamente, como vimos, parte do campo da pesquisa também foi realizado entre os anos de 2017 e 2018. Por isso, ao longo de nossa discussão, abordaremos tanto o contexto internacional das políticas de acolhimento e integração, quanto à realidade brasileira nos últimos anos.

Para tratarmos essa problemática, em um primeiro momento, realizaremos uma discussão sobre as distintas terminologias utilizadas no contexto migratório para fazer

\footnotetext{
9 Tradução livre do original: En ne parlant que de circulations et de flux, de gestion des entrants ou de contrôle des encombrants, on ne dépolitise pas uniquement la question des sans-État, on la déshumanise (p.33. 2008).
} 
referência às pessoas em deslocamento, seus distintos significados e as consequências de seus usos. Pretendemos, assim, tanto problematizar o emprego de categorias e distinção dos fluxos migratórios atuais, como nos posicionarmos diante desse contexto.

Em seguida, faremos uma discussão sobre as modalidades de gestão da questão migratória predominantemente adotadas pelos países mais ricos. Nesse ponto, tomaremos fundamentalmente o exemplo do contexto europeu, e mais precisamente a realidade francesa para compreender as formas pelas quais são produzidos os discursos hegemônicos em torno da figura do migrante - que na mesma medida dizem da produção dessa mesma figura na contemporaneidade. A partir dessas reflexões, pretendemos fundamentar bases para discutir o posicionamento do analista na clínica com sujeitos vivendo processos de deslocamento geográfico e cultural.

Tendo em vista essa discussão, concluiremos o capítulo tratando do contexto brasileiro, atravessado por uma nova geografia migratória nos últimos anos, e de algumas das iniciativas e políticas de acolhimentos e integração para as novas populações recém-chegadas na cidade de São Paulo, ressaltando o papel, na pesquisa, de instituições atuantes nesse campo: o abrigo Casa do Migrante, gerido pela Missão Paz, e o Centro de Referência para Refugiados, da Caritas Arquidiocesana de São Paulo.

\subsection{Imigrantes, migrantes, refugiados, exilados: tentativas de saída para um impasse}

Para começar - gostaria de me confiar a palavras que sejam, se possível fosse, nuas

(Jacques Derrida)

Impasse, em português, diz de uma "situação cuja saída ou resolução é praticamente impossível ou muito difícil [...] Aquilo que não tem saída [...] tudo o que pode dificultar ou impedir a realização de alguma coisa" (FERREIRA, 1999). Em francês, além desse mesmo sentido figurado, de impasse são chamadas todas as ruas sem saídas, os becos com começo e sem fim. Sendo assim, é a partir de um certo impasse que iniciamos nossa reflexão. Como nomear os sujeitos de nossa pesquisa sem fazermos emergir todos os discursos em torno de cada categoria e sem nos emaranharmos nessa mesma teia? Se nomear é instituir, trata-se também de limitar e reduzir. Dessa forma, como nos posicionarmos diante da guerra 
discursiva de categorias que pretendem homogeneizar experiências? Como botar relevo no que são as experiências singulares dos sujeitos sem perder de vista o contexto em que eles mesmos estão imersos? Ou, em seu inverso, como abordar o contexto sem perder de vista a singularidade de cada experiência?

A partir da definição de algumas das categorias para nomear pessoas em deslocamento geográfico pelo globo atualmente e da discussão de algumas das consequências do emprego desses mesmos discursos, trataremos não somente de contextualizar nosso campo de pesquisa como nos posicionaremos diante dessa questão.

Migrantes, refugiados, solicitantes de refúgio, imigrantes, exilados, deslocados internos, imigrantes econômicos, menores desacompanhados, refugiados ambientais, migrantes regulares, migrantes irregulares, clandestinos, errantes, viajantes, párias, apátridas, imigrantes indocumentados, sem papéis, imigrantes ilegais, devolvidos, retidos, repatriados, reassentados, retornados. Muitos são os termos atualmente empregados para referir populações mais pobres em deslocamento pelo globo. Diferentes são seus usos e empregos: do humanitário aos discursos políticos, dos acadêmicos aos meios de comunicação de massa, dos movimentos sociais à sociedade civil, não cessam as disputas entre discursos que pretendem abordar tanto o fenômeno contemporâneo dos deslocamentos como os sujeitos ativos nesse processo.

Se, por um lado, os diferentes termos pretendem abordar distintas naturezas de deslocamento e diferentes situações, seu emprego não é sem consequências. Trataremos de compreender algumas distinções entre essas categorias e seus efeitos. A partir dessa reflexão, justificaremos em seguida a escolha de algumas dessas denominações para nos referirmos aos sujeitos de nossa pesquisa, pois pensamos que não se trata de renunciar a todas essas categorias, senão de fazer um uso crítico delas, avisado de algumas de suas consequências e desdobramentos.

Em 1943, Hannah Arendt (1943), já exilada nos Estados Unidos, abriu seu texto "Nós, os refugiados" com a seguinte frase: "Em primeiro lugar, não gostamos de ser chamados 'refugiados'. Chamamo-nos uns aos outros 'recém-chegados' ou 'imigrantes'” (p.1). Primeiramente, podemos pensar que o termo Refugiado não se refere precisamente a nenhuma identidade étnica, cultural ou nacional, trata-se de uma condição provisória ou, ainda, de uma categoria daqueles que lograram obter reconhecimento institucional em determinado momento. 
Desde o ano de 1951, a Convenção de Genebra estabeleceu o Estatuto do Refugiado, definindo o direito para migrantes em determinadas condições de perseguição. A partir da Segunda Guerra Mundial, a Europa estabeleceu critérios de elegibilidade para acolher as populações em êxodo, mas tratava-se de uma convenção, em um primeiro momento, feita por e para os próprios europeus. Com as novas configurações históricas e novos fluxos, não só a convenção sofreu modificações, como sua interpretação e uso. Mas antes de abordarmos essa questão, passemos brevemente pela história e algumas das consequências da elaboração de um tratado internacional de reconhecimento e proteção de vítimas de perseguição. Para isso, tomaremos como mote introdutório a referência de Freud sobre a guerra e sua crença em uma instituição capaz de garantir sua regulação, para em seguida pensar em alguns de seus efeitos contemporâneos.

O comentário de Freud (1932) é sobre da Liga das Nações, entidade que precedeu as Nações Unidas como instituição regulatória da paz e da proteção da humanidade. Sua referência é de que a instituição falhou em seu propósito e sugere que outra coisa possa substituí-la, sem saber que, anos depois, seriam criadas não só a ONU como a Convenção de Genebra, estabelecendo os direitos internacionais do refugiado.

Em 1915, no segundo ano da Primeira Guerra Mundial, Freud introduz sua obra "Considerações atuais sobre a guerra e a morte" dizendo a respeito da violência e das perdas infligidas pela guerra: “jamais um acontecimento destruiu tantos bens preciosos da humanidade, jamais confundiu tantas inteligências das mais lúcidas e degradou tão radicalmente o que era elevado". A partir dessa repugnância à guerra, Freud dedicou um ensaio interrogando aquilo que considerou como a miséria psíquica dos não combatentes através de duas questões centrais: a desilusão causada pela guerra e a diferente atitude também provocada pela guerra - diante da morte.

Pessoalmente atingido pelo acontecimento, Freud teve três filhos ingressantes na guerra - Martim, que aos 25 anos serviu voluntariamente, Oliver, através da realização de projetos de engenharia, e Ernest, o caçula, também como voluntário no front italiano. Além disso, perdeu um sobrinho nessa mesma guerra, filho de uma irmã, e teve o genro, marido da filha Sophie, ferido em 1916 na França e, logo em seguida, afastado por invalidez.

Sobre a desilusão causada, Freud ressaltou o fato de a guerra ter transgredido todos os limites em direito internacional impostos em tempos de paz. Segundo ele, a guerra: 
não reconhece a prerrogativa dos feridos e dos médicos, a distinção entre a parte pacífica e a parte lutadora da população, nem os direitos de propriedade. [...] Ela destrói todos os laços comunitários entre os povos que combatem uns aos outros, e ameaça deixar um legado de amargura que por longo tempo tornará impossível o restabelecimento dos mesmos. (FREUD, 1915/2015, p. 234).

Em 1932, dezessete anos depois, em resposta às indagações de Albert Einstein sobre os problemas da paz mundial e a prevenção da guerra, em "Why war?", Freud sublinha o ponto que gostaríamos de tratar. Para ele, somente haveria uma segura prevenção contra a guerra na medida em que uma instância central superior pudesse reunir o poder necessário de decisão em todo conflito de interesses. Isto é, para ele, além da atribuição de legitimidade a essa instância superior, seria preciso que ela detivesse o poder necessário de intervenção. É nesse ponto, que, segundo Freud, o projeto da Liga das Nações falhou.

Para que haja uma transição da violência para o Direito, isto é, em uma perspectiva freudiana de evolução da violência para a lei, se faz necessário que uma condição psicológica seja satisfeita, a do sentimento de pertença:

A comunidade precisa ser mantida de forma permanente, precisa se organizar, criar preceitos que previnam as temidas rebeliões, estabelecer órgãos que velem pela obediência aos preceitos - às leis - e cuidem da execução dos atos de violência legítimos. O reconhecimento de uma comunidade de interesses produz vínculos afetivos entre os membros de um grupo unido de pessoas, sentimentos comunitários que são a base de sua autêntica força (FREUD, 1932/1976, p.421).

Dito de outra forma, trata-se da renúncia à violência pela transferência do poder a uma instância superior - que, por sua vez, se mantém através dos laços identificatórios de seus membros. Mas voltemos ao projeto da Liga das Nações e seu objetivo frustrado. Implementada em 1919, ao final da Primeira Guerra Mundial, a Liga das Nações reuniu as potências vencedoras para um acordo de paz. Em 1939, com a eclosão da Segunda Guerra Mundial, o objetivo da Liga das Nações de evitar novas guerras fracassa e ela se dissolve. Em 1946, suas responsabilidades são assumidas por um novo organismo, a ONU.

Depois dos horrores da Segunda Guerra e do estarrecimento do mundo com a revelação do Holocausto, estabelecia-se novamente um consenso internacional sobre a importância do exercício e cumprimento dos direitos humanos. Dessa vez, era necessário criar algo que pudesse garantir, a nível mundial, esses direitos. É assim que a Carta das Nações 
Unidas compele todos os países membros da organização a promoverem os direitos humanos. Em 1948, foi proclamada pela Assembleia Geral das Nações Unidas, em Paris, a Declaração Universal dos Direitos Humanos, como uma norma comum a ser atingida por todos os países. Pela primeira vez, parecia existir um dispositivo de proteção dos direitos humanos considerado universal.

Elaborada por representantes de diversos países e etnias, a Declaração foi traduzida para centenas de idiomas e expandiu consideravelmente o corpo do direito internacional. Nos anos que se seguiram, diversas convenções foram criadas, e são até hoje, com o objetivo de ampliar e modificar esses direitos, como por exemplo: a Convenção para a prevenção e a repressão do crime de genocídio (CONVENÇÃO, 1948), e, aquela sobre a qual nos debruçaremos a seguir, a Convenção de Genebra (CONVENÇÃO, 1951).

Vale destacar, ainda, que o intento de universalização dos direitos humanos tinha como concepção a noção de uma comunidade internacional para além das particularidades e limitações dos interesses e realidades de cada Estado-Nação. A partir de 1948, cada pessoa física passou a adquirir a qualidade de sujeito do Direito, estabelecendo assim o que o jurista Lindgren Alves (1998) considera como uma substituição da eficácia da força dos governos pela força da ética. Brevemente, podemos considerar que a declaração de 1948 estabelece os seguintes direitos universais aos indivíduos: direito à vida, à liberdade, à segurança pessoal; de não ser torturado nem escravizado; de não ser detido ou exilado arbitrariamente; à igualdade jurídica e à proteção contra a discriminação; a julgamento justo; às liberdades de pensamento, expressão, religião, locomoção e reunião; à participação na política e na vida cultural da comunidade; à educação, ao trabalho e ao repouso; a um nível adequado de vida, entre outros.

No entanto, Hannah Arendt (1951), no mesmo ano da Convenção, em sua obra As origens do totalitarismo, em capítulo dedicado à questão dos refugiados, infere a seguinte reflexão:

Nenhum paradoxo da política contemporânea é tão dolorosamente irônico como a discrepância entre os esforços de idealistas bem-intencionados, que persistiam teimosamente em considerar 'inalienáveis' os direitos desfrutados pelos cidadãos dos países civilizados, e a situação de seres humanos sem direito algum. Essa situação deteriorou-se, até que o campo de internamente - que, antes da Segunda Guerra Mundial, era exceção e não regra para os grupos apátridas - tornou-se uma solução de rotina para o problema domiciliar dos 'deslocados de guerra.' (p.311). 
Isto é, aquilo que era exceção e estava resguardado no âmbito do Tratado das Minorias $^{10}$, paradoxalmente, depois da Segunda Guerra Mundial e da declaração acerca da universalização dos direitos, tornou-se uma realidade vivida massivamente. Estabelece-se, portanto, segundo Arendt (1951), o paradoxo contemporâneo entre a jurisprudência que considera os direitos humanos inalienáveis dos cidadãos, e aqueles sujeitos que não portam direito algum. Mas tratemos de situar as diretrizes da Convenção que institui, então, pela primeira vez, o estatuto do refúgio.

A Convenção Internacional sobre o Estatuto dos Refugiados de 1951, realizada em Genebra, adicionada às retificações do Protocolo de $1967^{11}$, compreende que todos os países signatários desse acordo devem reconhecer como refugiado o indivíduo que:

devido a fundado temor de ser perseguido por motivos de raça, religião, nacionalidade, pertencimento a grupo social específico ou opinião política, encontre-se fora de seu país de nacionalidade (ou, no caso de apátridas, de seu país de residência habitual) e não possa ou, devido a tal temor, não queira retomar a ele (PROJETO, 1967, p.1).

Novamente, um paradoxo parece se apresentar no mesmo momento: na medida em que há diretrizes de reconhecimento para a solicitação de refúgio - ou seja, a garantia legal de proteção a um indivíduo por um Estado - estabelece-se, imediatamente, o contingente de pessoas sem nenhum estatuto legal, ejetadas, portanto, de qualquer direito de cidadania. Sem direitos a ter direitos. Se o reconhecimento da solicitação de refúgio garante o direito pela vida, os que não são reconhecidos estão à margem desse direito. Eis uma das problemáticas centrais da questão do refúgio.

A partir do estatuto de refúgio, cada país signatário tratou de desenvolver dispositivos de controle e reconhecimento. Triar os verdadeiros dos falsos (PESTRE, 2010) solicitantes de refúgio passa a ser uma tarefa não isenta de violência e arbitrariedade. Mais ainda, a partir da instituição do Refúgio como dispositivo de reconhecimento operando em torno da

\footnotetext{
${ }^{10}$ Sobre o Tratado das Minorias, Hannah Arendt completa: “Os apátridas e as minorias, denominados com razão 'primos em primeiro grau', não dispunham de governos que os representassem e protegessem e, por isso, eram forçados a viver ou sob as leis de exceção dos Tratados das Minorias - que todos os governos (com exceção da Tchecoslováquia) haviam assinado sob protesto e nunca reconheceram como lei -, ou sob condições de absoluta ausência da lei." (As Origens do Totalitarismo, 1951, p.302).

${ }^{11}$ Que inclui as cláusulas de reconhecimento para "grave ou generalizada violação de Direitos Humanos", como situações Guerra. A título de exemplo, atualmente os sírios têm sido reconhecidos através dessa resolução.
} 
necessidade ou da suspeição o sujeito tem que convencer ou dissimular sobre seu sofrimento para obter direitos. Segundo Hannah Arendt (1951),

como o homem sem Estado - um fora-da-lei por definição - era uma 'anomalia para a qual não existia posição apropriada na estrutura da lei geral', ficava completamente à mercê da polícia, que, por sua vez, não hesitava muito em cometer atos ilegais para diminuir a carga de indésirables no país. Em outras palavras, o Estado, insistindo em seu soberano direito de expulsão, era forçado, pela natureza ilegal da condição de apátrida, a cometer atos confessadamente ilegais" (p.316).

É da existência da figura jurídica do refugiado que se instaura seu alter ego negativo (AGIER, 2008), o clandestino, o sem papéis. Ser refugiado stricto sensu é depender da construção de uma narrativa correspondente ao previsto no estatuto - ou de sua interpretação. A todos os outros: a margem do direito de viver, ou de se instalar regularmente no país de refúgio. Iniciam-se assim, as modalidades de reconhecimento do sofrimento daqueles que logram convencer as instâncias competentes através de suas narrativas.

Para Hannah Arendt (1951), o mundo europeu sofreu um grande choque com o surgimento da figura do refugiado, choque que decorria daquilo que considerou uma dupla constatação: a "de que era impossível desfazer-se deles e era impossível transformá-los em cidadãos do país de refúgio, principalmente porque todos concordavam em que só havia duas maneiras de resolver o problema: repatriação ou naturalização " (p.324). É então, logo após os horrores do Holocausto na segunda guerra mundial, que se consolida, através do estatuto do refugiado, o reconhecimento jurídico do fazer viver alguns, e deixar morrer (FOUCAULT, 1976) outros tantos. Em "repatriação ou naturalização?", que vimos problematizado por Hannah Arendt, uma outra pergunta se anuncia, a de como resolver o problema. Em outras palavras, justamente aquilo que viria a se consolidar nos anos seguintes: instauram-se as modalidades de gestão dos indesejáveis.

Refugiados, portanto, de acordo com a Convenção de Genebra, são todos aqueles que lograram provar sua perseguição ou seu fundado temor no país de origem e foram reconhecidos e regularizados no novo país, gozam assim do direito de instalação e de proteção do país de acolhimento. São solicitantes de refúgio todos aqueles que, uma vez no novo país, solicitam às autoridades locais e instituições competentes o reconhecimento como refugiados, baseado nas experiências de perseguição que viveram em seus países de origem, pedido que, se acatado, será investigado, analisado e julgado pelas instâncias jurídicas. Ambas 
as categorias são compreendidas pela ACNUR como pertencendo às migrações forçadas ${ }^{12}$. Trata-se, como vimos, dos deslocamentos motivados por razões de perseguição ou por grave e generalizada violação de direitos humanos.

Podemos pensar que, diante dessas categorias, apresentam-se concomitantemente dois discursos complementares, o da imigração escolhida, e o da discriminação legítima (FASSIN, 2010), ou seja, políticas de integração de imigrantes operam, simultaneamente, como medidas restritivas de controle e triagem. Só há integração de imigrantes legais na medida em que houver mais restrição, controle e expulsão daqueles considerados ilegais. Estabelecer critérios de escolha para a migração é estabelecer, igualmente, parâmetros de discriminação considerados legítimos. Assim, a regulamentação do estatuto de refúgio também opera como uma certa fronteira - não menos imaginária do que qualquer outra - que instaura populações indesejáveis em uma sociedade normalizadora.

Nesse mesmo sentido, podemos pensar que, progressivamente, a função de proteção que havia sido exaltada no âmbito do estatuto do refúgio pela Convenção, passa a ser acompanhada pela de controle. Controle e gestão dos indesejáveis, eis o novo paradigma instituído. Dessa forma, a regulação dos sujeitos em deslocamento passa a estar, sobretudo, a cargo da polícia, instância que atua através de duas estratégias: identificando os indesejáveis através de nomenclaturas de populações específicas; e sua subsequente contenção sempre à margem (AGIER, 2008).

Sobre as definições e nomenclaturas que identificam e distinguem os corpos em trânsito enquanto população, uma reflexão de Hannah Arendt (1951), sobre esse tema, se faz pertinente. Citamos:

até a terminologia aplicada ao apátrida deteriorou-se. A expressão "povos sem Estado" pelo menos reconhecia o fato de que essas pessoas haviam perdido a proteção do seu governo e tinham necessidade de acordos internacionais que salvaguardassem a sua condição legal. A expressão displaced persons [pessoas deslocadas] foi inventada durante a guerra com a finalidade única de liquidar o problema dos apátridas de uma vez por todas, por meio do simplório expediente de ignorar a sua existência. O não-reconhecimento de que uma pessoa pudesse ser 'sem Estado' levava as autoridades, quaisquer que fossem, à tentativa de repatriá-la, isto é, de deportá-la para o seu país origem, mesmo que este se recusasse a reconhecer o repatriado em perspectiva como cidadão ou, pelo contrário, desejasse o seu retorno apenas para puni-lo (p.312).

12 “Forcibly displaced population" é o termo empregado pela ACNUR. 
Vemos, assim, que para Arendt, a categoria de pessoas deslocadas carrega de forma intrínseca sua intenção regulatória, assim como o não reconhecimento da condição de "sem Estado" desses sujeitos. Sendo assim, não se trata mais de colocar no centro a problemática de pessoas apátridas e as modalidades adotadas para incluí-las. Para Arendt, a substituição da noção de povos sem Estado por pessoas deslocadas revela a deterioração da terminologia de apátrida. É no surgimento dessa nova categoria que se instaura o desaparecimento das condições - ou o fazer desaparecer - das mesmas que pretendia representar. Nesse mesmo sentido, Jacques Hassoun (1998) se refere ao movimento paradoxal de fazer suscitar o outro enquanto categoria, a fim de negar, precisamente, sua alteridade, na dinâmica dupla de fazer aparecer para desaparecer.

Desse modo, a necessidade de distinção - que podemos considerar aqui como categorização pelas terminologias - que faz do outro seu reconhecimento por insígnias, seja com intenção de proteger ou excluir, produz sempre a diferenciação. Através da regulação, portanto, fazendo aparecer é que se produz o desaparecimento. Nessa mesma lógica, "é preciso situar os inquietantes estrangeiros no espaço. Para preservá-los em sua função de estrangeiros, designá-los, e no mesmo movimento, fazê-los desaparecer" (HASSOUN 1998 apud KOLTAI 1997, p.92). Assim, instaura-se o que Hassoun (1998) intitula de dupla enunciação contraditória, modo pelo qual cada época trata de fundar, em função de seu próprio imaginário, os contornos de um outro odiável.

Categorizações são, nessa perspectiva, modos pelos quais se produzem dinâmicas de invisibilização. A designação produz, no mesmo movimento, a diferenciação e os contornos do que se apaga, tanto da singularidade, como do contexto político de produção do fenômeno.

Dessa forma, vimos como as categorias utilizadas culminam por responder, finalmente, à mesma intenção regulatória de proteção e controle. Traduzidas institucionalmente, proteção e controle representam atualmente os dois principais atores de regulação de estrangeiros: organizações humanitárias e instâncias de segurança - realizando a intricada união que Dider Fassin (2017) nomeou como sécuritaire (humanitário + segurança). Preocupação humanitária e inquietação securitária produzem, nesse sentido, tecnologias bastante extensas de gestão dos estrangeiros. A proliferação dessas categorias para gerir o fluxo de pessoas torna cada vez mais obscuros tanto os verdadeiros números, como as condições de vida e todas as razões de deslocamento dessas mesmas pessoas. Temos então 
categorias, pessoas reagrupadas em função de condições estritamente delimitadas e de graus de vulnerabilidade. Temos delimitadas as populações de indesejáveis.

Sobre a categoria dos migrantes econômicos, devemos nos concentrar brevemente em alguns pontos. Na lógica instituída a partir do estatuto da figura do Refugiado, o sentimento de suspeição das autoridades gira em torno da seguinte questão: se a narrativa do solicitante de refúgio não for verdadeira, trata-se de um refugiado mentiroso, de um migrante econômico 'travestido' de refugiado. Diante dos mecanismos de elegibilidade, a partir dos critérios estabelecidos pelas instituições, temos a palavra do sujeito.

Espectro do refugiado, o imigrante econômico é aquele que, no imaginário institucional regido pela suspeição, pretende simular suas narrativas para obter direito de instalação. Com migrações cada vez mais restringidas ao longo do tempo, os deslocamentos motivados por razões econômicas ocupam um lugar menor, não só na obtenção de direitos e reconhecimento, quanto diante das instituições regulatórias que em caráter policialesco buscam justamente triar os verdadeiros (refugiados) dos falsos (migrantes econômicos).

Entretanto, haja vista as evidências ilustradas pelos números, diante das imensas populações em êxodo ao redor do globo, como é possível diferenciar estritamente pessoas que se deslocam por razões de guerra, perseguições, condições de miséria, pobreza extrema, catástrofes naturais, ou motivados pela pura errância? Ou ainda, em um mesmo Campo humanitário, como separar os migrantes que são refugiados por perseguições os viajantes, errantes ou migrantes econômicos? Distintas populações em deslocamento compartilham o mesmo fenômeno em que, mais do que tênue, a fronteira entre cada uma das categorias é construída.

Globalização, neoliberalismo, crises econômicas e políticas, período pós-colonial, guerras, catástrofes da natureza, podemos enumerar alguns fatores que giram em torno de um movimento bastante próprio do funcionamento capitalista que se caracteriza por dispor constantemente de algo de fora de si mesmo para se estabilizar. Segundo o geógrafo David Harvey (1989),, por um movimento dialético, o sistema capitalista depende, no interior de sua cadeia acumulativa, das próprias massas que trata de expulsar, e, desta forma, não faz nada menos que engendrar crises que lhe são intrínsecas. Em outras palavras, diante desses números, se nos ativermos a esse movimento, podemos constatar a produção social do deslocamento no mundo contemporâneo. 
A acumulação de capital na contemporaneidade se configura, também, pelas relações entre o capitalismo e os modos de produção não capitalistas. Ou seja, é internalizando práticas predatórias e fraudulentas de espoliação que o capitalismo cria seu próprio outro, e assim, a custo muito baixo, recicla o conjunto de ativos (força de trabalho) que tratou de ejetar. Segundo Harvey (1989), em uma perspectiva de retroalimentação, a acumulação por espoliação gira a economia e produz mais capital. Nesse sentido, são a massa de desempregados - as antigas colônias, e por que não pensar, as ondas de sujeito em deslocamentos - as reservas latentes de populações expulsas do modo de produção capitalista, para serem, em alguma medida, absorvidas novamente.

Desse modo, pobreza e perseguição são dois elementos propulsores de deslocamento no mundo e de difícil separação, pois geralmente encontram-se intrincados. No entanto, os critérios de elegibilidade que garantem os direitos de proteção e instalação no país de refúgio são claros e a necessidade de forjar uma narrativa crível e adaptada às injunções institucionais passa a ser um imperativo de sobrevivência. Nessa lógica, segmenta-se a noção do migrante econômico como a figura de maior suspeição, essa que no imaginário xenófobo viaja aos países mais ricos para "roubar" o trabalho dos nacionais, "onerar" os serviços públicos e "usurpar" os Estados de bem-estar social desenvolvidos. Considerar migrações como escolhidas, ou desejadas, implica em criar dinâmicas de invisibilização dos processos estruturais do capitalismo de produzir exclusão, violência e deslocamento. Pois nas condições de pobreza, assim como nas de perseguição, os mesmos direitos humanos são infligidos. E tomando isso por base, não só migrar é um direito como também a possibilidade de se instalar em qualquer parte.

Sendo assim, a separação entre refugiados e migrantes econômicos frequentemente é arbitrária, produz distinção moral sobre o reconhecimento de direitos, assim como dinâmicas de exclusão e violência. Trataremos mais longamente (capítulo 4) sobre o posicionamento clínico diante dessa problemática, mas gostaríamos de sublinhar que, ao longo da pesquisa, quando utilizamos da terminologia refugiados para nos referir aos sujeitos da pesquisa, não estamos levando em conta essa distinção moral com migrantes econômicos, a partir de um reconhecimento jurídico. Apartados da lógica institucional regida pela suspeição, para nós, na clínica, refugiados são todos aqueles que nomeiam a si mesmos dessa forma, ou que decidiram se refugiar em um novo país por condições extremadas de vida no lugar de origem. 
Diante de todos esses impasses colocados, a nomeação de pessoas em deslocamento no contexto dos fluxos atuais como simplesmente migrantes é uma saída alternativa para alguns autores às injunções de uma economia moral de produção de sujeitos indesejados. $\mathrm{O}$ emprego do termo migrantes opta por não ter que definir, de antemão, entre imigrantes e refugiados. Segundo Agier (2016), a opção pela terminologia migrante para se referir a populações em trânsito apresenta-se como uma saída à categorização arbitrária entre refugiados, migrantes econômicos, viajantes ou errantes, pois por migrante entende-se a condição de movimento dos sujeitos em deslocamento, isenta de julgamento.

No entanto, outros pensadores são enfáticos em discordar desse posicionamento. Para Alexis Nouss (2016), por exemplo, o emprego do termo migrante remete puramente às estatísticas, aos relatórios econômicos e, portanto, à objetificação e invisibilização dos sujeitos e suas trajetórias. Falar em migrante não é fazer referência a um sujeito, nem às suas vivências ou percursos, pois trata-se de um vocabulário quase animal que retira a condição humana dessas populações. Assim, a saída adotada por Nouss é pelo termo exilados, léxico que se refere não só a uma condição humana inexorável, como um termo que, de certa forma, responsabiliza toda a humanidade pelo fenômeno.

No mesmo caminho teórico, a antropóloga Alexandra Galitzine-Loumpet (2014) sustenta o potencial heurístico da noção de exílio e seu emprego no campo das migrações. Nesse sentido, falar em exílio implicaria em uma inversão do paradigma espaço-temporal utilizado quando referimo-nos às migrações. Isto é, muito mais do que fazer menção à condição humana, o termo migrante marca somente a relação do sujeito com o tempo e espaço ao redor. Sendo assim, exílio:

é a experiência no tempo, no atemporal do tempo, que constitui o núcleo existencial comum - de Ovídio aos naúfragos de Lampedusa. A experiência do exílio é fundada sobre a descontinuidade e a coexistência, isto é, sobre uma temporalidade movida pelo espaço, mas que a submete lhe multiplicando e lhe agregando, inclusive no imaginário. A migração mascara as rupturas dos percursos migratórios em uma homogeneização do sujeito, um fato classificatório; a experiência do exílio transforma essa descontinuidade como permanente do sujeito, fazendo igualmente aparecer o "alhures" como um antes ou um depois suscetíveis de se cavalgar. A experiência de exílio torna-se narração - com seus buracos e silêncios e, como tal, pode ser reivindicada por diferentes gerações fora de qualquer ligação territorial (p.190). 
Exílio, ou exilados para os sujeitos, é a categoria utilizada por aqueles que pretendem adotar uma outra denominação dos sujeitos em deslocamento. Falar em migrações em vez de exílio, nessa perspectiva, implica numa assignação que mascara tanto as rupturas como as complexidades das trajetórias de deslocamento, homogeneizando a experiência do exílio em classificações e nomeações redutoras. Portanto é como exílio e enquando exilados que podemos resguardar a potência da experiência humana de deslocamento ao redor do globo.

Exílio é também, para a psicanálise, a condição inexorável. Desde Freud, com a conceitualização do inconsciente, tudo o que fora produzido até então passou a ser questionado e uma perspectiva radical foi revelada: sujeito dividido, a verdade não é mais relativa ao conteúdo manifesto, mas ao latente. Ou, em outras palavras, pensamos com Rosa e Nogueira (2017) que "a dimensão trágica do migrante encena algo comum a todos, pois todos somos sujeitos exilados, desenraizados de nós mesmos, constituídos pelo desconhecimento enigmático da dimensão inconsciente" (p.1). Exílio é, assim, condição humana marcada pela divisão de sua própria dimensão inconsciente. Exilados são todos os sujeitos.

Finalmente, em relação a esse debate, veremos que ao longo da pesquisa serão empregados alguns desses termos, pois, uma vez problematizados, pensamos que não se trata de renunciar a eles, mas de fazer um uso que leve em conta a ordem dos discursos em jogo. Por esse motivo, ao longo da escrita da tese empregamos os termos de refugiados, exilados, migrantes, imigrantes, recém-chegados e deslocados para nos referir a sujeitos que em suas trajetórias recentes de vida se deslocaram pelo globo nos últimos anos. Mais do que as nomeações enquanto categorias cristalizadas e redutoras, o que nos interessa são as possibilidades de botar em relevo as experiências singulares narradas pelos sujeitos. Assim, o deslizamento entre algumas dessas categorias permite pensar mais na singularidade dos casos do que nos discursos institucionais que os circundam. Trata-se, enfim, de narrativas concomitantemente particulares e universais, pois, ainda que circunscritas em um mesmo contexto, revelam toda a complexidade das tramas individuais de cada percurso.

Antes de abordarmos a perspectiva clínica da pesquisa, tendo em vista a presente discussão sobre as categorias, gostaríamos ainda de analisar outras injunções sociais presentes na realidade das migrações atualmente, e nesse sentido, abordar algumas das políticas hegemônicas utilizadas no campo dos deslocamentos contemporâneos. 


\subsection{Política do muro, política da indiferença e a necropolítica: modos de governar indesejáveis}

Se o processo de globalização tem sido caracterizado pela circulação quase irrestrita do capital, cada vez mais os corpos submetem-se a uma trama muito bem delimitada. Viajar para além dos muros dos grandes blocos econômicos - é verbo intransitivo exclusivamente para populações de determinados países, classes sociais elevadas ou turistas - todos aqueles que gozam da pretensa liberdade de deslocamento através das companhias aéreas e seus passaportes apropriados ou devidamente carimbados, mas praticamente apenas a título de consumo - aos outros, quase todos, do além-mar, o deslocamento e a deriva parecem ser os únicos destinos possíveis (GEBRIM, 2012; GLEICH, 2015). Transações comerciais, envio e recebimento de divisas, compras de mercadorias (tantas vezes isentas de impostos) de qualquer espécie em plataformas online são operações efetivadas em poucos segundos por meio de qualquer dispositivo eletrônico, tal como um smartphone ${ }^{13}$. Concomitantemente a esse fenômeno, assistimos à proliferação de muros, barreiras e fronteiras construídas para impedir o trânsito livre de pessoas em busca de se deslocarem ou se instalarem. No curso desse processo, também centenas de milhares de pessoas morrem, a cada ano, naufragadas em mares, desertos ou nos perigosos percursos rumo aos países em que buscam refúgio ou instalação.

Nessa mesma linha, Bauman (1998) pensou a globalização como um processo que simultaneamente une e divide, sendo as causas da divisão as mesmas que promovem união em torno do mundo.

Junto com as dimensões planetárias dos negócios, das finanças, do comércio e do fluxo de informação, é colocado em movimento um processo "localizador", de fixação no espaço. Conjuntamente, os dois processos intimamente relacionados diferenciam nitidamente as condições de existências de populações inteiras e de vários segmentos de cada população. $\mathrm{O}$ que para alguns parece globalização, para outros significa localização; o que para alguns é sinalização de liberdade, para muitos outros é um destino indesejado e cruel. ${ }^{14}$

${ }^{13}$ É importante lembrar que todo smartphone é produzido através do metal Coltan, um mineral que é extraído por trabalho escravo na República Democrática do Congo e que ocasiona grande parte dos conflitos e precarizações e violências na região, impelindo grande parte dos deslocamentos do país.

${ }^{14}$ Bauman, 1998. Pag. 7 Zygmunt Bauman Globalização: As consequências humanas. Jorge Zahar Editor Rio de Janeiro 1999. 
Isto é, globalização para determinados setores e localização para outros. Se o mundo dos negócios e das finanças é marcado pela livre-circulação, como tratamos, a de certos corpos tem sido cada vez mais caracterizada por processos de profunda restrição. E, nesse sentido, se permanecer localizado é indício de privação material e degradação social, são esses os corpos restringidos pelos impedimentos de circulação. Entretanto, os números de deslocamento nunca foram tão elevados e a cada ano aumentam. Vamos a eles.

Segundo estatísticas recentes ${ }^{15}$ da ACNUR, a agência da ONU para refugiados, é possível estimar que, em 2017, 44.400 pessoas se deslocaram por dia de suas próprias casas por razões de perseguição. Os números parecem exorbitantes e, a cada ano, atingem novos recordes. Em relação a 2016, as chamadas "migrações forçadas" ${ }^{16}$ aumentaram 2,9 milhões no ano seguinte. Em 2017, foram contabilizadas 68,5 milhões de pessoas em todo o mundo que se deslocaram de suas residências fugindo de violências ou perseguições.

De forma mais abrangente, podemos pensar que a passagem para o século XXI foi marcada pela produção massiva de novas populações em deslocamento. Nos últimos anos, novas configurações sociopolíticas vêm delimitando também novos caminhos migratórios. Os eixos sul-sul, assim como Norte-Sul, passaram a desenhar novas rotas substituindo as tradicionais sul-norte. Para compreender o aumento considerável de novos fluxos migratórios no hemisfério sul e mais precisamente, no Brasil, alguns fatores serão considerados.

$\mathrm{O}$ crescente fechamento das fronteiras nos países mais ricos e endurecimento das políticas de acolhimento a imigrantes na Europa e nos Estados Unidos é um desses elementos. Segundo o economista e cientista político Luis Carlos Bresser-Pereira (2010), a crise global do ano de 2008, oriunda de uma crise bancária no ano anterior, representou aquilo que viria a ser, em suas palavras: "uma virada na história do capitalismo [...] uma crise social que, segundo previsões da Organização Internacional do Trabalho, elevou o número de desempregados de cerca de 20 milhões para 50 milhões ao fim de 2009" (BRESSERPEREIRA, 2010, p.13). Sendo assim, na mesma medida em que os fluxos migratórios se intensificaram para o hemisfério norte, a impossibilidade dada às barreiras políticas e físicas também, impelindo assim que novas rotas fossem traçadas.

Ademais, diversos conflitos a partir do ano de 2010 na África e Oriente Médio impulsionaram o fluxo mais acentuado em relação aos anos anteriores para diversas partes do

\footnotetext{
${ }^{15}$ Referimo-nos à publicação da ACNUR sobre os dados do ano de 2017.

16 Termo empregado pela ACNUR para se referir à refugiados e solicitantes de refúgio, a ser discutido a seguir.
} 
globo. Entre eles, podemos citar a invasão da Líbia pela OTAN em 2010, a guerra da Síria em 2011, a guerra do Sudão, o surgimento do Estado Islâmico, entre vários outros conflitos. Diante desse cenário, diversos setores políticos e dos meios de comunicação passaram a falar em uma "crise migratória" europeia a partir de 2015, termo profundamente questionado por estudiosos, como já abordado, tendo em vista o número de pessoas em relação à população e ao território europeu (BOUAGGA, 2017).

Diante desse cenário, constatou-se igualmente a proliferação de projetos políticos ancorados em discursos xenófobos e, cada vez mais, o tema das migrações passou a pautar não só as principais agendas dos países, como tem sido central nos debates políticos e presidenciais pelo mundo. Em um manifesto de repúdio à atual política de alguns países europeus diante dos novos fluxos de deslocamentos, os intelectuais Michel Agier, Étienne Balibar, Judith Butler, Étienne Tassin (2016) lançaram um manifesto intitulado "Sem alternativa: direito de asilo ou barbárie". No texto, destacam que o conjunto dos países europeus tem não só os meios de acolher os refugiados e os tratar dignamente, como devem fazê-lo para seguir reivindicando os direitos humanos enquanto fundamento de sua constituição política, e a si mesmos como países de liberdade. No entanto, essa parece ser, desde as colonizações, a contradição de alguns países europeus: a de sustentar o ideal da liberdade e da democracia às custas da dominação e subtração dos países do sul.

Dentre os 68,5 milhões de pessoas deslocadas por razões de perseguição no ano de 2017, 40 milhões foram deslocados internos (pessoas que se deslocaram no interior do próprio país) e 5,4 são palestinos sob gestão da UNRWA (ONUBR, 2018). Do montante de pessoas que se deslocaram para o exterior dos seus países buscando proteção, 6,3 milhões eram provenientes da Síria, 2,6 milhões do Afeganistão, 2,4 milhões do Sudão do Sul, 1,2 milhões de Myannmar e 986,400 mil da Somália (Ibid). Nesse contexto, os países que mais receberam pessoas fugindo de situações de perseguições, contabilizadas por esses dados, foram a Turquia, que recebeu 3,5 milhões, o Paquistão com 1,4, Uganda também com 1,4 e o Líbano com 998,900 pessoas. Isto é, na gramática do deslocamento, grande parte dos que migram fugindo de perseguições não logram cruzar fronteiras e deslocam-se apenas internamente. Vemos assim, que quando se consegue atravessar os limites nacionais, são os países mais pobres ou fronteiriços os que mais acolhem pessoas em emergência. 
Aporofobia é um neologismo criado recentemente para designar a aversão a pessoas pobres. Do grego “áporos”, pobre, sem recurso, a filósofa Cortina Orts (2017) nomeia assim o fenômeno de rejeição das populações mais pobres em todo o mundo. Segundo ela, a intolerância de alguns governos e de parte da sociedade civil aos grandes fluxos atuais de pessoas para os países mais ricos não representa somente um caráter de xenofobia, pois não configura uma aversão a qualquer estrangeiro. Estrangeiros ricos, ou turistas que gastam dinheiro, não são somente bem-vindos como estimulados a viajarem. Portanto, trata-se, atualmente, da aversão não a qualquer estrangeiro, mas aos estrangeiros pobres nos países ricos, isto é, das populações do Sul pelas populações do Norte.

Nesse sentido, podemos pensar que os atuais fluxos de pessoas vêm suscitando, dos principais Estados que os recebem, uma ordem de respostas de restrição e contenção regidas predominantemente por três grandes eixos: a política do muro, a política da indiferença e a necropolítica (MBEMBE, 2018). A título ilustrativo, propomos pensá-los brevemente como três distintos discursos e formas de administração, no entanto, partimos da ideia do intrincamento dessas três modalidades para pensar na produção da figura do migrante pobre, visto como indesejável. Trata-se, assim, dos modos de exclusão e de segregação no laço social, que, na mesma medida, também informam sobre as formas de gestão e produção social do deslocamento. Aqui, entendemos a produção desses discursos, predominantemente, a partir de três grandes instâncias institucionais: as políticas governamentais; as práticas do setor humanitário, de assistência e da sociedade civil; e os discursos dos grandes meios de comunicação de massa ou produções culturais. Tomaremos principalmente o exemplo europeu como ilustração ao largo de toda a discussão.

A construção de novos muros, sejam eles de cimento, muros elétricos, ou de arames, alguns deles através de redes informatizadas, monitoradas e altamente militarizadas, tem sido um fenômeno crescente nas fronteiras dos Estados mais ricos e em todos os países que recebem novas populações migrantes. Quanto mais desenvolvido e militarizado o país, mais sofisticadas são as tecnologias de barreira e impedimento de novas pessoas. Assim, através da figura do muro, em seu sentido metafórico e literal, ou ainda, muro como lugar (espaço) ou como objeto (barreira física), podemos compreender certos modos de gestão e administração da questão migratória atualmente. No mesmo sentido com que Bauman (2015) se referiu aos 
"os muros de cimento de quatro metros de altura, cercas, centros de detenção e acampamentos que aguardam os invasores" ${ }^{\prime 17}$, trata-se de dispositivos de defesa que através da contenção física de corpos indesejáveis pelo muro nos informam sobre como o espaço público tem sido concebido.

Como figuras paradigmáticas, pensemos dos nos muros entre a Palestina e Israel, Espanha e Marrocos, Estados Unidos e México, Grécia e Turquia, entre outros. Mas podemos também pensar na fronteira imaginária, e também altamente militarizada e informatizada, instaurada pela União Europeia no Mar Mediterrâneo, ou na construção dos Hotspots ${ }^{18}$ que proliferam em distintos países de entrada, e ainda em outras zonas de retenção e zonas de espera $^{19}$ - espaços de confinamento, contenção e identificação de pessoas em seu livre arbítrio para se deslocar, como também nas políticas de externalização das fronteiras ${ }^{20}$ e na ideia de “países tampões” pela Europa.

Novamente, a mesma ambivalência que tratamos anteriormente. Se a globalização vem produzindo livre circulação para o capital, multiplicam-se os modos de retenção e fixidez de certos corpos. O processo de desterritorilização progressiva das grandes empresas ou outras iniciativas socioeconômicas de exploração vêm acompanhados do reforço das fronteiras como objeto físico (muro) e como lugar (espaço cindido pela barreira) de práticas administrativas de exclusão de indivíduos (MAKAREMI, 2009). Nesse sentido, compreender a figura do muro também como um lugar, nos ajuda a pensar não apenas sobre a produção do espaço público ao seu redor, como nas modalidades de gestão de pessoas tidas como indesejáveis. As fronteiras como lugar de produção de espaço ou como objeto físico de barreira configuram centros de conflito no mundo atualmente.

Segundo o sociólogo Didier Bigo (2014), a ampla abordagem midiática sobre as mortes de pessoas nos naufrágios durante as travessias para se chegar ao continente europeu tem gerado grande controvérsia sobre o atual controle de fronteiras. No entanto, para ele, essa

${ }^{17}$ Bauman, 1998. Pag. 9 Zygmunt Bauman Globalização: As consequências humanas. Jorge Zahar Editor Rio de Janeiro 1999.

${ }^{18}$ Hotspots são centros de retenção para migrantes recém-chegados nas praias europeias vindo de embarcações. Nesses centros, os migrantes ficam por tempo indeterminado para procedimentos de controle, biometria, e em alguns casos, devolução.

${ }^{19}$ Zonas de espera são locais geralmente nos aeroportos internacionais em que pessoas migrantes em situação documental irregular ficam retidas para controle. No aeroporto de Guarulhos, em SP, a zona de espera chama-se "Conector".

${ }^{20}$ Externalização de fronteiras tem sido uma política cada vez mais adotada pela União Europeia de controle dos fluxos migratórios. Trata-se do policiamento e desenvolvimento de dispositivos de controle e barreira em outros países ou continentes para coibir e coagir o fluxo de deslocamento antes de chegar na Europa. 
é só a ponta do iceberg que encobre um fenômeno maior e muito menos abordado: a situação de dezenas de milhares de pessoas que diariamente são detidas, devolvidas e impedidas de entrar na União Europeia. Seja por contenção ou por ações de dissuasão (pelas intervenções militares e policiais), através da filtragem ou triagem (dos centros de retenção e dos mecanismos de controle e elegibilidade), a proliferação das fronteiras informatizadas por dados (fluxos identificados pela inteligência militar, biometria), ou as smartborders ${ }^{21}$, informam sobre a governança biopolítica da construção de categorias de suspeitos e prevenção da entrada de pessoas indesejáveis. Assim, o controle atual das fronteiras opera tanto através da disciplinarização dos corpos (pelos identificadores biométricos, centros de retenção, pela discriminação de determinadas pessoas e nacionalidades através da produção de dados e estatísticas), como representam um refinamento da lógica biopolítica, em que as tecnologias computadorizadas permitem coletar vestígios para organizar a vigilância de entrada de certas pessoas (BIGO, 2014).

Paralelamente à análise sobre o poder disciplinar que se dirige ao corpo com seus mecanismos, técnicas e tecnologias de poder, Michel Foucault (1976) trabalhou a perspectiva da biopolítica como aquela que toma não somente o homem-corpo, mas o homem-vida, o homem-espécie. Que o saber científico, biológico, assuma um caráter político em determinando momento define, para Foucault, seu conceito de biopolítica. Isto é, quando o discurso científico é o que "justifica e mantém práticas segregativas" (FOUCAULT, 1976, p.96) socialmente. O campo da biopolítica, característica da modernidade ocidental, se define pela captura do discurso biológico para regulação dos corpos no registro individual e coletivo. Qualidade de vida passa a ser um registro central, e população seu principal alvo. Como consequência desse campo, a demografia constitui-se como ciência, saber voltado sobretudo para a regulação populacional. Vida, morte e diferentes idades passam a ser também reguladas nesse mesmo âmbito do controle biopolítico. Segundo Birman (2007), em decorrência disso:

estamos lançados assim no campo da higiene social, que dominou o processo de medicalização ao longo do século XIX. O espaço social foi então meticulosamente esquadrinhado, de forma que as categorias do normal, do anormal e do patológico, passaram a definir as ações normativas dos dispositivos biopolíticos. A periculosidade social se enunciou como uma problemática crucial nesse contexto, de maneira que o crime e a loucura foram inscritos neste projeto de normalização infinita do espaço social.

\footnotetext{
${ }^{21}$ Smartborders é um conceito que tem também sido cada vez mais adotado pelas políticas de migração da União Européia de informatizar os sistemas de controle e restrição das fronteiras.
} 
Enfim, as classes perigosas passaram a ser um dos alvos fundamentais da regulação biopolítica (p.4).

As tecnologias biopolíticas de poder instauram, nesse sentido, uma sociedade da normalização, que estabelece mecanismos reguladores com seu novo corpo: a população. No campo da higiene social, são as classes perigosas, segundo Foucault (1976), as que serão objeto maior das técnicas biopolíticas de regulamentação. Se em 1951, por ocasião da convenção sobre estatuto de refúgio e logo após o surgimento da ACNUR, Hannah Arendt já anteviu a situação dos apátridas - os sem Estado - como os indésirables aos países europeus, podemos pensá-los, como continuação - no âmbito da regulação biopolítica - como população representante das classes perigosas.

Partindo da figura do muro, é possível avançar um pouco mais a respeito das tecnologias de contenção e produção de espaço, e pensar em duas perspectivas que se desdobram daí: a extramuros (do muro para fora) e a intramuros (do muro para dentro).

Desde a barreira física muro, dois ângulos se desdobram, portanto. Como vimos brevemente, as modalidades de gestão extra-muros podem ser compreendidas como todas aquelas relacionadas às medidas de segurança das fronteiras, à militarização e ao controle fronteiriço, ao policiamento em diferentes estágios do deslocamento, centros de detenções e zonas de espera, à inibição dos deslocamentos nos locais de trânsito e à gestão dos países tampões, assim como às ações contra o que se considera tráfico humano ${ }^{22}$; em suma, uma ampla gama de práticas que configuram a crimigration $^{23}$, categoria que compreende o processo gradual de criminalização das migrações atualmente. De forma crescente, vemos em medidas governamentais como essas a associação entre formas de migração e crime. Todas essas modalidades de contenção e gestão dos fluxos de populações são mais profundamente analisadas pelos autores Bigo (2014), Makaremi (2009) e Agier (2016, 2017).

Desde a perspectiva intramuros, outras formas de gestão e contenção têm sido também amplamente empregadas no contexto das migrações. Aqui podemos pensar em algumas políticas de integração (GEBRIM, 2012), nos dispositivos de elegibilidade e imigração escolhida ${ }^{24}$, na gestão humanitária dos grandes campos de refugiados, assim como nos dispositivos clínicos de saúde mental voltados para, dentre o conglomerado em

\footnotetext{
${ }^{22}$ Trataremos mais sobre a controvérsia em torno desse tema no capítulo 4 da tese.

${ }^{23}$ Crimigration é o termo que alguns autores adotam para pensar o fenômeno da criminalização das migrações.

${ }^{24}$ Trataremos mais profundamente desse tema no capítulo 4.
} 
deslocamento, os que apresentam mais sofrimento, e o processo decorrente de patologização do deslocamento ${ }^{25}$. Criminalização e patologização, portanto, parecem figurar como dois discursos que se desdobram da política do muro, e que no contexto humanitário são regidos pela lógica compassiva de assistência e ajuda.

Muro como estrutura de defesa, como mensagem de indiferença e recusa, como alegoria de felicidade interna. Para Christian Dunker (2015), trata-se de uma estrutura tal como um véu, que sinaliza tanto a recusa para os que habitam o fora, como a afirmação da unidade e bem-estar para os que estão dentro:

o muro é uma estrutura de defesa contra a falta (pedido), uma mensagem de indiferença contra o outro (recusa), uma alegoria de felicidade interna (oferecimento) e uma negação indeterminada de reconhecimento (não é isso). O muro - ou a estrutura de véu, quando se trata do fetichismo - diz invariavelmente 'não é isso' para os que estão fora e, por consequência, 'é isso' para os que estão dentro (DUNKER, 2015, p.64).

Segundo Dunker (ibid), na homologia entre formas de vida e tipos de sofrimento, ou ainda, entre processos sociais e processos psíquicos, o muro representaria a figura da indiferença, exclusão e segregação, que, através da fronteira, se faz habitado por uma demanda: "e uma demanda implica um circuito entre um pedido (como 'Mantenha a distância - cão bravo'), uma recusa (como 'Propriedade particular - não entre'), uma oferta (como 'Seja bem-vindo à Morada dos Eucalíptos') (ibid, p.65). Para o autor, não por acaso, os muros se tornaram também lugares privilegiados de intervenções gráficas em que novas resistências ou demandas se inscrevem.

Se a instauração da figura do muro em sua produção de espaço, de um lado, restringe e delimita o trânsito e a passagem, isto é, impede que pessoas acessem o espaço em seu interior, não cessam as modalidades de gestão e contenção intramuros, como vimos. Ou seja, políticas de controle e restrição tanto aos indesejados que lograram cruzar as barreiras dos muros, como aqueles retidos e contidos em lugares terceiros - como é o caso dos grandes campos de refugiados nos países mais pobres, e geridos por organizações dos países mais ricos do mundo.

Dentre as modalidades empregadas na perspectiva intramuros, para as populações indesejadas, algumas ações humanitárias no campo das migrações atualmente servem de

25 Sobre esse tema e o alastramento da categoria de trauma no contexto das migrações, trabalharemos mais profundamente no capítulo 3 da tese. 
ilustração. O antropólogo Michel Agier (2008), após longa etnografia em campos de refúgio de diversos países, sustenta a tese de que a gestão de estrangeiros operada pelas instituições humanitárias assume uma forma de governo: trata-se do governo humanitário. Por mundo humanitário no âmbito das migrações, podemos compreender as incontáveis instituições de assistência, ajuda e emergência em diversos contextos do processo migratório. Ou ainda, como define Agier (2008), as EOC (Enormes Organizações de Caridade), encarregadas de manter em vida as populações resto do mundo. Segundo o antropólogo, a nível mundial, a função do dispositivo humanitário pode ser descrita com o que ele define de mão esquerda do império $^{26}$. Isto é, aquela que visa atenuar os efeitos enunciados pelas intervenções militares, ditaduras locais, e explorações econômicas em países do terceiro mundo. Em suas palavras, trata- se de uma lógica em que:

uma mão que bate e a outra que cuida. Vimos de forma grotesca nas duas intervenções militares dirigidas pelo exército americano no Afeganistão em 2001 e no Iraque em 2003: a distribuição de alimentos e de medicamentos acompanhavam o lançamento das bombas; a avaliação do número de sobreviventes e de órfãos potenciais a serem alimentados foi publicado com antecedência; a localização precisa e a cartografia dos futuros campos para um número anunciado de populações deslocadas, assim como instalação de barracas e entregas de militares de cobertas anteciparam os efeitos programados das operações militares (AGIER, 2008, p.297).

O governo humanitário, como descrito, encarna em seu dispositivo as tecnologias de regulamentação das populações que representam simultaneamente categorias tais como as de vulneráveis e indesejáveis, vítimas e suspeitas. Através da retórica da urgência, as intervenções humanitárias tornam, muitas vezes, a barbárie instaurada pelas ações do imperialismo mais suportável.

Através da proliferação de muros e dispositivos de fronteiras constituem-se, dessa forma, diversas “armadilhas locais" (BIGO, 2014) em que pessoas são forçadas a viver onde não querem. Não só a possibilidade de circulação e trânsito de certas populações são cerceadas pela política do muro, como também seu direito de instalação onde desejam estar. Pessoas oriundas dos países do Sul convertem-se, assim, em populações indesejáveis pelos países mais desenvolvidos do globo.

${ }^{26}$ Referência de Agier (2008) à noção de Pierre Bourdieu (1992) de "Mão esquerda do Estado" sobre os assistentes sociais e sua função no aparelho de Estado. Pag 296. 
Nesse contexto, sujeitos que se deslocam dos países mais pobres para os mais desenvolvidos e estáveis são vistos pelos mecanismos de gestão, mais como números, dados, estatísticas, fluxos homogêneos de populações que não são bem-vindas, do que em suas narrativas singulares e suas problemáticas específicas. Assim, podemos pensar em algumas formas pelas quais as razões de buscar um novo lugar para viver são cada vez mais ofuscadas pela difusão excessiva da imagem de contingentes de populações em sofrimento em trânsito, sem rostos, nomes ou histórias. Passemos rapidamente por alguns aspectos do que chamaremos da política da indiferença em torno da figura do migrante.

Imagens de naufrágios no Mar Mediterrâneo, ou de barcos superlotados, caminhões abarrotados de pessoas no deserto do Saara, fotografias de crianças desacompanhadas em campos de refugiados, famílias inteiras empreendendo deslocamentos perigosos e sendo rechaçadas pela polícia, imagens dos trânsitos de pessoas no frio do inverno europeu, ou ainda outras fotografias e imagens que acompanham os percursos migratórios em quilômetros de caminhada. Corpos mortos nas praias europeias, boiando pelos mares, ou apenas alguns coletes salva-vidas simbolizando os corpos desaparecidos. Todas essas tornaram-se, nos últimos anos, cenas ordinárias para o cidadão de qualquer país que tenha acesso a meios de comunicação em massa, e são igualmente imagens que adentram cotidianamente a intimidade do lar de todos aqueles que têm acesso a jornais ou ainda meios virtuais de informação. Basta invocar a figura de barcos no Mediterrâneo, ou do menino Aylan ${ }^{27}$ deitado de bruços na praia, para partirmos de uma mesma representação imagética.

Com a ampla difusão de imagens do fenômeno dos deslocamentos atuais a partir do drama humano de seus protagonistas, podemos nos perguntar sobre os efeitos gerados pela informação nas principais populações consumidoras dessas imagens e notícias. Trata-se de veiculações que geram indignação, engajamento e transformação? Ou precisamente seu oposto, imagens que produzem anestesia, insensibilidade, indiferença e impotência diante do sofrimento? Se, por um lado, podemos pensar que ver de forma nítida e aproximada o drama do terror perpetrado pelos conflitos poderia gerar indignação, assistimos à indiferença

\footnotetext{
27 Aylan é o nome do menino curdo que, após naufrágio no mar mediterrâneo, teve seu corpo morto na praia retratado por uma fotografia.
} 
generalizada, tanto da opinião pública, como das principais políticas governamentais dos países mais ricos sobre a situação das pessoas em deslocamento.

Prolongando esses questionamentos, é possível considerar que essas informações produzem alguma reflexão aprofundada ou crítica em relação ao fenômeno dos deslocamentos? Ou ainda, quais seriam os efeitos de um fenômeno tanto difundido, por um lado, quanto pouco contextualizado por outro, e em seus desdobramentos estéticos nas principais populações consumidoras de informação? Tratemos de compreender melhor, nesse sentido, algumas das formas pelas quais a difusão dessas imagens contribui para produção da figura do migrante como indesejável. De um lado, pelo excesso de difusão de imagens de sofrimento e a produção estética implicada no consumo das informações, e de outro, pela instrumentalização e despolitização do fenômeno dos deslocamentos.

Há quinze anos, Susan Sontag (2003) tratou sobre o efeito de anestesia produzido frente à impossibilidade de suportar, de forma contínua, ser confrontado com a dor dos outros. O que representa o excesso de imagens de carnificinas humanas ou de corpos em extremo sofrimento? Mais ainda, o que a entrada do horror da guerra no espaço doméstico produz, em termos estéticos? São predominantemente dessas perguntas que Sontag parte para sua investigação sobre as reações Diante da dor dos outros:

Ser um espectador de calamidades ocorridas em outro país é uma experiência moderna essencial, a dádiva acumulada durante mais de um século e meio graças a esses turistas profissionais e especializados conhecidos pelo nome de jornalistas. Agora, guerras são também imagens e sons na sala de estar (SONTAG, 2003, p.20).

De forma geral, o contato mediático com o desespero de certas populações é confluente com o processo de invisibilização e indiferença em relação às reais condições de seus protagonistas. Nesse mesmo sentido, a antropóloga Chiara Pussetti (2017) propõe a reflexão de que os fenômenos de hipervisibilização do sofrimento estão na base da produção social da indiferença. Paradoxo entre processos de hipervisibilidade e invisibilização, Pussetti (ibid) sugere a ascensão de uma relação complexa e ambígua entre piedade, curiosidade e indiferença.

Podemos problematizar alguns elementos acerca da banalização do sofrimento de algumas populações em detrimento do vivido por outras. Isto é, por que são tão familiares as imagens de corpos mortos de migrantes náufragos nas praias europeias, ou de africanos, 
árabes ou outros povos asiáticos em guerras e perseguições atuais, e não a dos europeus ou norte-americanos mortos ou feridos em atentados terroristas? Em referência a essa questão, Sontag (2003) nos lembra que nenhuma imagem de corpos em sofrimento foi veiculada na ocasião do 11/9 nos Estados Unidos, enquanto os exemplos de conflitos como a Guerra de Biafra, na Nigéria, ou do Genocídio de Ruanda, da guerra da Síria, entre outros, revelam seu oposto.

Há, nesse sentido, uma dupla função contraditória da fotografia, a de captar o real, mas sempre sob determinada perspectiva. Pois fotografar é sempre escolher um ângulo, e o ato da câmera de enquadrar revela sempre uma exclusão de outras partes. Trata-se, portanto, de uma tomada de posição, de, a cada lado de determinado conflito, se apropriar das imagens que lhe cabem à sua maneira.

O contato com o horror produz, de forma contínua, reações de fascínio diante das imagens tanto indecentes quanto obscenas. E, assim como ocorre com a curiosidade e certa satisfação sentidas ao passarmos de carro após um acidente na estrada, por exemplo curiosidade voyeur quando as vítimas não são nossos familiares - "a fome de imagens que mostram corpos em sofrimento é quase tão sôfrega quanto o desejo de imagens que mostram corpos nus" (SONTAG, 2003, p.38). Nesse sentido, se o fascínio pelas imagens dos corpos estrangeiros parece quase pornográfica, quando os corpos são familiares, a discrição parece ser o modelo que impera.

Indiferença, anestesia e o sentimento de impotência diante do acontecimento e da inevitabilidade da tragédia são afetos dirigidos aos corpos estrangeiros. Afetos dirigidos a tudo o que se passa somente do lado de lá, marcando assim o exotismo e a clara linha entre "nós" e "eles". É nesse sentido que Sontag (2003) considera que as fotos atrofiam a sensibilidade e embotam os sentimentos em relação a tudo que é considerado como não familiar. Ou, ainda, é na difusão excessiva dessas imagens - e na forma como são mostradas que se produz aquilo que não é familiar, pois, na mesma medida, são os conflitos que se tornam cotidianos e familiares a esses corpos indesejáveis. Diante disso, os consumidores de imagens tornam-se profundamente insensíveis e indiferentes.

Talvez as únicas pessoas com direito a olhar as imagens de sofrimento dessa ordem extrema sejam aquelas que poderiam ter feito algo para minorá-lo digamos, os médicos do hospital militar onde a foto foi tirada - ou aquelas que poderiam aprender algo com a foto. Os restantes de nós somos todos 
voyeurs, qualquer que seja nosso intuito. Em cada exemplo, o horripilante nos convida a ser ou espectadores ou covardes, incapazes de olhar (p.39).

A título de ilustração, podemos tomar a recente exposição fotográfica Farida, um conto sírio, em cartaz no MIS (Museu da Imagem e do Som) ${ }^{28}$, em São Paulo, que mostra a jornada de uma família síria durante um mês em seu deslocamento até a Suécia para pensarmos em alguns elementos discutidos. As fotografias da exposição são arrebatadoras e, através das lentes do fotógrafo, vemos a intimidade de uma família ao longo de seu percurso de deslocamento, experiência de incursão que revela perspectivas quase nunca captadas pelas lentes da imprensa. No entanto, as fotografias parecem não bastar e a curadoria da exposição faz apelo a outros recursos: somos convocados a nos afetar através de outros sentidos, para além das fotografias, somos convidados a experenciar um ambiente semelhante ao retratado na foto e, sensorialmente, através do olfato e do tato, caminhamos na palha seca e somos convocados a viver naquele instante o percurso de deslocamento da família de Farida. O impacto é grande, mas a exposição acaba, e a afetação se dissipa em uma estranha e complexa conjunção de piedade, apelo e também da sensação de impotência frente à tamanha catástrofe. Logo saímos da grande sala da exposição, e tornamo-nos pequenos e distantes demais de tudo aquilo que acontece em alguma parte do mundo, supostamente longe de nós, pois nos encontramos novamente na segurança do lar.

Novamente, dois aspectos da produção da indiferença valem uma breve reflexão. O primeiro deles se refere à despolitização dos fenômenos em questão. Na representação do sofrimento através da hiper-visibilização, vemos corpos, rostos, que têm estatuto de idênticos entre todos eles, sem história, sem contexto, sem nenhuma marca de implicação, são pura personificação da figura de vítima, ou ainda representação última daquilo que Hannah Arendt (1951) tratou como a "abstrata nudez de ser apenas homem”, nada mais, nas Origens do Totalitarismo. Sabemos dos corpos em sofrimento, conhecemos as imagens, mas não sabemos nada daquilo que nos implica na produção social do fenômeno. Temos a vítima, mas com o preço da subtração de sua história, de seu contexto, e de sua singularidade.

Nesse sentido, carregando a marca da indiferença, a instrumentalização política das imagens passa a ser um recurso central dos países mais ricos, legitimando as políticas de muro de contenção, controle e dissuasão das populações mais pobres de circularem e se instalarem

${ }^{28}$ Exposição em cartaz no MIS, em São Paulo em 2016 do fotografo brasileiro Mauricio Lima, premiado pelo Pulitzer. 
onde desejam. O segundo ponto é o que vimos também problematizado por Sontag (2003) sobre a obscenidade veiculada nos corpos - sempre estrangeiros - e na discrição reservada ao sofrimento dos que são familiares. Segundo Chiara Pussetti (2017): “o sofrimento de quem é próximo, dos nossos amigos e familiares, merece maior discrição: a morte dos 'nossos' é para ser respeitada e protegida, certamente, não exposta pornograficamente” (s.p.). O excesso de imagens dos corpos em sofrimento revela, nesse sentido, também a obscenidade que não suportaríamos com corpos daqueles de quem sabemos a história, e que temos como caros. $\mathrm{Na}$ esteira dos processos de invisibilização, são os corpos mais visibilizados os menos desejáveis, e os mais matáveis.

Assim, a política da indiferença - ou a produção social da indiferença, é um processo hegemônico tanto na representação e a consequente produção da figura do migrante como indesejável, como um elemento confluente aos modos de gestão e contenção de seus corpos ao redor do mundo. Nesse sentido, poderíamos destacar ainda um elemento a mais em torno dessa discussão, as políticas de morte, ou a necropolítica (MBEMBE, 2018), pois mais do que criação de barreiras e controle, vemos a produção de destruições e de morte em larga escala para determinadas populações.

Dissemos até aqui sobre as inúmeras medidas de restrição, contenção e identificação dos corpos dos sujeitos mais pobres em deslocamento, tratamos sobre o efeito espacial e representacional dessas implementações de controle e gestão. Chamamos de política de muro as medidas que produzem contenção física, seja pela presença militarizada ou de assistência e cuidado - isto é, da perspectiva extra-muros e intra-muros de governabilidade e restrição de trânsito e instalação de migrantes aos países mais ricos. Em seguida, tratamos brevemente sobre os efeitos de anestesia e indiferença produzidos pelo excesso de difusão de imagens e notícias sobre corpos em extremo sofrimento descontextualizados das condições de deslocamento, da história e singularidade dos atores protagonistas nas migrações. Paradoxo entre hiper-visibilização e invisibilização, abordamos aspectos da produção da indiferença em torno da figura do migrante como indesejável.

Intrincada a esses elementos, podemos ainda adicionar uma terceira reflexão e abordar aspectos do que o filósofo camaronês Achille Mbembe (2018) conceitualizou como a necropolítica. Para ele, a noção foucaultiana de biopolítica é insuficiente para compreender algumas das formas atuais de submissão da vida ao poder da morte. Necropolítica e necropoder são as maneiras pelas quais algumas políticas atuam com o objetivo de provocar o 
máximo de morte de pessoas em determinados contextos, e, concomitantemente, criando mundos de morte como formas de existência social, isto é, espaços em que vastas populações são submetidas a condições de vida quase como mortos-vivos (ibid). Os exemplos trabalhados pelo autor se referem historicamente à plantation e aos modos de organização da colônia no período da colonização, e atualmente, à política do Estado de Israel sobre o povo palestino na faixa de Gaza e nas ocupações.

Para fundamentar essas reflexões, Mbembe (2018) parte da noção foucaultiana de poder soberano e biopolítica. Para compreender, façamos um breve retorno aos conceitos. $\mathrm{O}$ poder do soberano, segundo Michel Foucault (1976) caracterizado como "poder absoluto, dramático, sombrio" (FOUCAULT, 1999, p.295), estava baseado na soberania de fazer morrer e deixar viver. Dito de outra forma, a natureza do poder do soberano sobre a vida de seus súditos era fundamentada em seu direito ilimitado e irrestrito de matar quem lhe parecesse necessário: "é porque o soberano pode matar que ele exerce seu direito sobre a vida"(ibid, p.287). Para Foucault, esse é o direito da espada, direito caracterizado pela lógica de fazer morrer e de deixar viver. Assim caracteriza-se o soberano, ou seja, os efeitos de seu poder só se efetuam na medida em que ele detém o poder de matar. Tanto quanto de morte, seu poder é também de deixar os súditos viverem.

Porém, na passagem para o século XVIII, e mais consolidada nas transformações do direito político do século XIX, há uma mudança substancial nessa lógica, e um novo direito, segundo Foucault, virá não “apagar o primeiro, mas vai penetrá-lo, perpassá-lo, modificá-lo, e que vai ser um direito, ou melhor, um poder exatamente inverso: poder de 'fazer' viver e 'deixar' morrer”(ibid, 287). A regulamentação daquilo que Foucault nomeia como o poder biopolítico será, portanto, baseada na lógica contrária, os discursos de poder são o de fazer viver. Surgem então, como vimos anteriormente, através das disciplinas biológicas, médicas, demográficas, epidemiológicas, as tecnologias que intervêm para aumentar e aperfeiçoar a vida; e, consequentemente, o poder de deixar morrer aos que permanecerem às margens - ou totalmente excluídos das intervenções de regulamentação de vida.

Como um poder como este pode matar se é verdade que se trata essencialmente de aumentar a vida, de prolongar sua duração, de multiplicar suas possibilidades, de desviar seus acidentes, ou então de compensar suas deficiências? Como nessas condições, é possível, para um poder político, matar, reclamar a morte, pedir a morte, mandar matar, dar a ordem de matar, expor à morte não só seus inimigos mas mesmo seus próprios cidadãos? Como esse poder que tem essencialmente o objetivo de fazer viver pode 
deixar morrer? Como exercer o poder da morte, como exercer a função da morte, num sistema político centrado no biopoder? (FOUCAULT, 1999, p.304).

$\mathrm{Na}$ tentativa de dar sentido a esses questionamentos, Foucault compreende o racismo como uma das modalidades discursivas que produz o corte necessário entre os sujeitos que devem viver e os que podem ser deixados morrer. Nesse sentido, a noção de raça e os efeitos do racismo são elementos que produzem as "condições de aceitabilidade" (p.306) para deixar morrer alguns no exercício do poder biopolítico. Deixar alguns tantos morrerem consiste, nessa perspectiva, em um poder que garante o fortalecimento da crença biológica de uma raça, ou a unidade de uma população. O paralelo com o discurso xenófobo, ou, como dissemos, aporofóbico, nos aproxima dessa compreensão biopolítica de construção de inimigos potenciais.

Racismo é acima de tudo uma tecnologia destinada a permitir o exercício do biopoder, 'este velho direito soberano de matar'. Na economia do biopoder, a função do racismo é regular a distribuição da morte e tornar possíveis as funções assassinas do Estado (MBEMBE, 2018, p.18).

Assim, o poder trabalha para produzir exceção, emergência e, incessantemente a figura de um inimigo ficcional (MBEMBE, 2018). Necropoder, nesse sentido, corresponde a todas as dinâmicas de fragmentação territorial, do acesso proibido a certas zonas, da expansão dos assentamentos (no caso israelense na Palestina), provocando, com esses movimentos tanto a impossibilidade de circulação como a permanente segregação entre pessoas. Enquanto táticas do necropoder, Mbembe (Ibden) aponta as características de uma guerra infraestrutural, com o exemplo da ação de bulldozers, operações de terras arrasadas, demolições de casas e cidades. E, nesse sentido, como não pensar nas ações diárias de desmobilizações de acampamentos de migrantes nos territórios em que são tidos como indesejados?

Falamos previamente sobre a proliferação de dispositivos de fronteira, controle e identificação, e igualmente abordamos o fenômeno de hiper-visibilização dos corpos de migrantes em sofrimento através de imagens midiáticas. Resta, ainda, um outro elemento a ser tratado por nós: a desmobilização das instalações provisórias de migrantes nas cidades mais ricas. Aqui nos referimos mais uma vez, predominantemente, ao contexto europeu, por 
considera-lo relevante para compreender algumas das modalidades hegemônicas que vêm direcionando as principais políticas migratórias no mundo.

Em paralelo a todo o fenômeno recente de deslocamento que narramos neste capítulo, uma nova modalidade de instalação provisória, mas muitas vezes perene, multiplicou-se nas grandes cidades europeias: os acampamentos de migrantes em barracas. As mesmas barracas desde sempre usadas nos campings de lazer (BOUAGGA, 2017) são as utilizadas por migrantes em deslocamento nas principais cidades. Acampamentos provisórios, não se trata de barracas das organizações humanitárias ou dos contêineres ${ }^{29}$ dos abrigos de instalação, mas de conglomerados espontâneos, autogeridos e desordenados em diferentes pontos das cidades, quase sempre mais periféricos, reunindo dezenas e às vezes centenas de migrantes recémchegados ou no curso de seus deslocamentos. Acampamentos por vezes lotados e que concentram diferentes pessoas provenientes de distintos percursos e nacionalidades, e também motivadas por várias razões e projetos de novos países de instalação. Pessoas que se aglomeram para se proteger e garantir a sobrevivência diária para seguir no périplo da jornada de deslocamento.

Essa presença nova e massiva de uma outra forma de ocupar o espaço público nas cidades - pelos acampamentos nas barracas de campings - parece revelar dois aspectos predominantes: por um lado, a ausência de mecanismos e políticas de acolhimento, instalação e integração efetivas para essas pessoas; por outro, a fabricação desses mesmos campos em detrimento do estreitamento das fronteiras. Uma vez instaladas nesses acampamentos provisórios, as pessoas confrontam-se com uma nova realidade, a dissolução diária dessas estruturas. Com frequência, as polícias locais, geralmente durante a noite, retiram à força as pessoas lá instaladas: seja com gás lacrimogênio e cavalaria (nos casos dos acampamentos maiores), ou jatos d'água e a subtração de barracas e cobertores, a cada noite.

Tática de demolições e desmobilizações, vemos esboçadas aí algumas das tecnologias do necropoder em que a infraestrutura é constantemente atacada como forma de criar zonas de impossibilidade de vida. Em cidades como Paris, é possível ver a ação policial para impedir associações de assistência de distribuírem comida e água, os banheiros públicos constantemente são retirados, e todas as condições de garantia de uma sobrevivência mínima são destruídas. Resta a condição de morto-vivo (MBEMBE, 2018), sem possibilidade de se

\footnotetext{
${ }^{29}$ Nova modalidade arquitetônica de "estocamento" de corpos precários ao redor do mundo. Em São Paulo, podemos vez nos novos CTAs do centro da cidade.
} 
instalar, de se alimentar, ao relento nos invernos europeus mais rigorosos, na chuva, e sujeitos à violência policial constante. Na necropolítica do deslocamento vemos em diversos exemplos $^{30}$ o poder de fazer morrer. À guisa de conclusão desse primeiro capítulo, uma citação de Mbembe sobre a produção social do deslocamento como um necropoder:

A extração e o saque dos recursos naturais pelas máquinas de guerra caminham de mão dadas com as tentativas brutais para imobilizar e fixar espacialmente categorias inteiras de pessoas, ou paradoxalmente, para soltálas, forçando-as a se disseminar por grandes áreas que excedem as fronteiras de um Estado territorial. Enquanto categoria política, as populações são então decompostas entre rebeldes, crianças-soldados, vítimas ou refugiados, civis incapacitados por mutilação ou simplesmente massacrados ao modo dos sacrifícios antigos; enquanto os 'sobreviventes', depois de um êxodo terrível, são confinados a campos e zonas de exceção (MBEMBE, 2018, p.58).

Discorremos brevemente sobre alguns dos principais aspectos que configuram os atuais fluxos de deslocamentos pelo globo e a forma como os países mais ricos têm empregado tecnologias de captura, controle e gestão - e nesse sentido, de governabilidade dessas mesmas pessoas. Novamente, pessoas oriundas dos países do Sul, países mais pobres, muitas vezes antigas colônias dos países europeus, e tidos como presenças indesejáveis. Política do muro, política da indiferença e necropolítica, são modalidades de desumanização de sujeitos reduzidos à necessidade. Desumanizados em seu potencial desejante, veremos mais adiante, são esses mesmos corpos os que insistem nos périplos mais ardilosos provando sua resistência às múltiplas modalidades de captura, exploração e aniquilação.

\footnotetext{
${ }^{30}$ Mbembe (2018) dá o exemplo da RDC (República Democrática do Congo) para pensar algumas estratégias do necropoder. Como já tratamos, há anos, a RDC vive um conflito armado intenso relacionado a exploração de seus minerais. Citamos um trecho aqui: "o fluxo controlado e a demarcação dos movimentos de capital em regiões das quais se extraem recursos específicos tornaram possível a formação de 'enclaves econômicos' e modificaram a antiga relação entre pessoas e coisas. A concentração de atividades relacionadas à extração de recursos valiosos em torno desses enclaves tem, por sua vez, convertido esses enclaves em espaços privilegiados de guerra e morte. A própria guerra é alimentada pelo crescimento das vendas dos produtos extraídos".
} 


\subsection{As "novas" migrações para o Brasil e as rotas Sul-Sul dos deslocamentos contemporâneos}

Utilizamos a expressão "novas" migrações para o Brasil (SAGLIO-YATZIMIRSKY; GEBRIM, 2017) para nos referirmos a um fluxo mais acentuado para o país, a partir de 2011. A nova geografia migratória vem desenhando novas rotas de deslocamento no globo. Veremos, então, como aspectos desse fenômeno vêm impactando a realidade brasileira. No entanto, é necessário se levar em conta que, ainda que tenha havido um aumento considerável de novos fluxos migratórios para o Brasil nos últimos anos, em relação aos países de outros continentes, ou em relação à sua própria população, o montante de pessoas recebidas é muito pequeno.

Números oficiais apontam que as solicitações de refúgio no Brasil cresceram aproximadamente $3000 \%$ em cinco anos. Isto é, se em 2010 foram registrados 566 pedidos de refúgio, em 2014 já eram mais 12 mil, dentre os quais 5.136 de solicitantes residindo na cidade de São Paulo ${ }^{31}$. Por meio desses dados, é possível vislumbrar, portanto, um aumento expressivo de solicitações de refúgio no Brasil a partir do ano de 2010. Tratemos de compreender, então, em que consiste esse aumento e qual a natureza do recente fluxo migratório.

O Comitê Nacional para os Refugiados - CONARE, instância responsável no Brasil por analisar as solicitações de refúgio e deferir os pedidos realizados ${ }^{32}$, é um órgão colegiado e interministerial sob a coordenação do Ministério da Justiça. Segundo dados de 2017 contabilizados pelo Comitê ${ }^{33}$, existem atualmente no Brasil, 10.145 refugiados reconhecidos, dentre os quais, uma maioria de $39 \%$ de nacionalidade síria, seguida por congoleses da República Democrática do Congo, colombianos, palestinos, paquistaneses e malineses.

\footnotetext{
${ }^{31}$ Dados Acnur de 2017: no ano de 2010, o Brasil recebeu 566 solicitações de refúgio, em 2011, foram 1138, em 2012, 2008 solicitações, em 2013, 5882 foram contabilizadas e, finalmente, no final do ano de 2014, foram mais de 12 mil pedidos, dentre os quais, 5.136 solicitantes residindo na cidade de São Paulo.

32 O comitê é presidido pelo Ministério da Justiça, e composto pelo Itamaraty (vice-presidência), Ministério da Saúde, da Educação, do Trabalho e Emprego, pela Polícia Federal e por outras organizações não governamentais como as Caritas Arquidiocesanas de São Paulo, Rio de Janeiro e Manaus, o Instituto Migrações e Direitos Humanos (IMDH), de Brasília, a Associação Antônio Vieira (ASAV) e o Centro de Defesa dos Direitos Humanos $(\mathrm{CDDH})$. É responsável pela análise de reconhecimento da condição de refugiado, em primeira instância, e pelas declarações de cessação e de perda da condição de refugiado.

33 Dados oficiais do CONARE, 2018.
} 
Nesse montante não estão contabilizadas as pessoas de nacionalidade haitiana. Desde o ano de 2010, em consequência do terremoto, houve igualmente uma migração expressiva proveniente do Haiti. No entanto, esses casos são encaminhados diretamente ao Conselho Nacional de Imigração (CNIG) para concessão de permanência por razões humanitárias ${ }^{34}$. Os mesmos dados revelam que desde 1997, 86.007 pessoas solicitaram refúgio no Brasil, considerando que a maior parte se deu nos últimos cinco anos. Da população de solicitantes e refugiados, cerca de $70 \%$ são homens, entre 18 e 39 anos. Além disso, há de se levar em conta outras migrações internacionais, como bolivianos, peruanos, outros fluxos latino-americanos, não contabilizadas entre esses dados, mas que compõem de forma expressiva o fluxo migratório para o Brasil nas últimas décadas.

Para dar sentido às diferentes dimensões dessas "novas" migrações para o Brasil nos últimos anos, é preciso também levar em conta o contexto nacional desse mesmo período. Nesse sentido, os anos que antecederam o início da intensificação de novas chegadas foram determinantes para compreender o fenômeno.

O período do governo Lula, compreendido entre os anos 2003-2010, teve como principal característica no âmbito da política externa, representada pelo Ministro das Relações Exteriores Celso Amorim, a aproximação com os países africanos da costa ocidental, com países árabes, e alguns países asiáticos. Delimita-se desde então um novo desenho estratégico em política internacional. Segundo Pinheiro Guimarães (2012), o Brasil, "exceto o caso especial da China, estreitou relações com os países considerados do Sul, no que o Presidente Lula e o Chanceler Celso Amorim chamaram de uma nova geografia econômica e política mundial".

Se considerarmos, portanto, a adoção de uma nova geografia de prioridades nas relações externas, o Brasil passou a contribuir com novos fluxos de fortalecimento econômico e político em relação aos governos anteriores, em que predominavam trocas com os países da Europa Ocidental, Estados Unidos e Japão. Assim sendo, além do fortalecimento do eixo SulSul de relações políticas e econômicas, o governo desse período também teve como agenda central a estruturação do Mercado Comum do Sul - Mercosul, organização intergovenamental fundada em 1991, que visa à integração entre países da América do Sul. Durante esse período, o Brasil passou a assumir um papel de protagonismo nas decisões e transações empreendidas pela organização.

${ }^{34}$ Resolução CNIG n 08/2006 e Resolução Normativa CNIG n 27/1998. 
Em paralelo a esse contexto das relações internacionais, no que se refere à política interna brasileira durante o governo Lula, diversos programas sociais foram implementados, gerando um considerável impacto na economia interna. Programas sociais de estímulo às camadas mais pobres da sociedade impulsionaram a economia e produziram ascensão social e mais poder aquisitivo para uma parcela da população. Além de figurar internacionalmente como uma economia em expansão, podemos conjecturar que conjuntamente a todas essas políticas, as escolhas do Brasil para sediar a Copa do Mundo de 2014 e as Olimpíadas de $2016^{35}$ contribuíram para aumentar a visibilidade internacional do país nesse mesmo período.

Fundamentalmente por meio desses dos dois elementos, isto é, das medidas do governo empreendidas em política externa e interna, é possível figurar os novos fluxos migratórios, sobretudo no que diz respeito à solicitação de refúgio nos últimos anos. Com a visibilidade internacional e o crescimento econômico, o Brasil passou a representar um destino atrativo de possibilidades e leis regulatórias de migração não tão restritivas.

Ainda na tentativa de compreender a relação da política externa com os países do continente africano e Oriente Médio, podemos explorar alguns elementos. Segundo o próprio Chanceler Celso Amorim, a aproximação das relações com a África representa para o Brasil uma obrigação histórica, pois, nas palavras do ministro: “com 76 milhões de afro-descentes, o Brasil é a segunda maior nação negra do mundo, atrás da Nigéria, e o governo está empenhado em refletir essa circunstância em sua atuação externa” (AMORIM, 2003, p.3). No período dos governos Lula e Dilma, o Brasil passou a ter uma expressiva presença diplomática no continente africano. Das 54 nações africanas, o Brasil contava com embaixadas em 37 países, considerando que 19 foram abertas desde o primeiro mandato de Lula.

Por outro lado, desde 2004, o governo brasileiro assumiu mais uma função que reforçava sua posição de força expressiva na região sul, passou a coordenar a Missão das Nações Unidas para a Estabilização no Haiti, a MINUSTAH. A missão de paz formada pelo Conselho de Segurança das Nações Unidas visava restaurar a ordem pública logo após a deposição do presidente haitiano Jean-Bertrand Aristide. Nesse sentido, a expressiva delegação brasileira de soldados, assim como o papel de liderança do Brasil, aproximou a relação dos dois países. Se a missão tinha como objetivo pacificar e estabilizar as condições

35 É interessante notar que muitos vistos para chegar ao Brasil foram conseguidos no contexto desses dois megaeventos. No entanto, chegando ao Brasil, pedia-se refúgio. 
políticas do Haiti, a controversa permanência brasileira foi justificada também depois do terremoto de 2010.

Outro elemento recente a ser considerado no contexto brasileiro é o caso sírio. Desde a eclosão da guerra na Síria, em 2011, o acolhimento a refugiados dessa nacionalidade se intensificou. Uma resolução oficial do CONARE, em 2013, considerou que em razão dos laços históricos entre Síria e do Brasil, e da crise humanitária de grandes proporções pela guerra, os solicitantes de refúgio sírios no Brasil seriam automaticamente reconhecidos. Além disso, a emissão de visto brasileiro em embaixadas vizinhas à Síria seria facilitada. Essa resolução teve duração de dois anos, e foi suspensa pelo presidente Michel Temer, por ocasião do golpe parlamentar que depôs a presidenta eleita Dilma Rousseff, em 2016.

A partir da conjunção desses elementos, podemos compreender um novo posicionamento estratégico do Brasil no cenário internacional que, na mesma medida, também passou a receber novos fluxos migratórios de muitos dos países com os quais estabeleceu relações políticas e econômicas. No entanto, é preciso destacar que o período de ascensão econômica e visibilidade internacional iniciado no governo Lula e estendido no governo Dilma, vive crise profunda desde o ano de 2014, no Brasil. O segundo mandato da Presidenta Dilma, desde seu início, em 2015, foi marcado por uma grave crise política, acompanhada pela recessão econômica.

Com a crise econômica e o aumento significativo da taxa de desemprego desde 2015, os fluxos migratórios têm diminuído e o Brasil deixou de ser o destino predominante em relação à América do Sul para alguns grupos. Desde o final de 2015, números apontam uma queda sensível em relação à solicitação de refúgio e à chegada de haitianos e outras nacionalidades no Brasil. Contudo, outros fluxos, como o venezuelano, passaram a se acentuar. No entanto, decidimos por não abordar esse aspecto uma vez que o período que compreende a presente pesquisa se refere aos fluxos de migração internacional para o Brasil em um período um pouco anterior.

No contexto brasileiro, a cidade de São Paulo figura como de suma importância. De acordo com os dados recentes do CONARE, 28\% dos pedidos de refúgio em 2017 foram realizados em São Paulo e, entre refugiados reconhecidos e solicitantes de refúgio, 52\% vivem na capital paulista. Trata-se de uma cidade com tradição de acolhimento migratório bastante diversificada, haja vista não somente o contingente proveniente da Europa ao largo do século XIX e XX, mas também as migrações árabes, asiáticas, sul-americanas e todos os 
fluxos internos da região nordeste e norte do país. Assim, veremos a seguir algumas das principais políticas de acolhimento e integração, tanto da sociedade civil como estatais, para a população migrante na cidade de São Paulo

A chegada desse novo fluxo nos últimos anos (2010 a 2017) não foi acompanhada pela implementação substancial de políticas públicas de integração e acolhimento. Algumas experiências governamentais foram empreendidas em cidades brasileiras, mas até muito recentemente, grande parte das demandas de acolhimento e integração institucional eram realizadas por instituições humanitárias. Nesse contexto, é possível constatar a ausência do Estado, substituído pela massiva assistência de instituições e equipamentos gerenciados pela igreja católica em todo o país.

Para compreender algumas políticas de acolhimento institucional dessa população na realidade brasileira, é preciso analisar seu histórico. A legislação vigente até o ano de 2017 sobre assuntos migratórios datava do período da ditadura militar, com a elaboração, em 1980, do Estatuto do Estrangeiro (BRASIL, 1980), que considera a figura do imigrante como ameaça à segurança nacional. Segundo Ventura e Illes (2012), com a vigência dessa lei, permanecia:

\footnotetext{
em vigor no direito brasileiro um florão da Guerra Fria [...] um legado amargo do regime militar. Consagração máxima do paradigma da segurança nacional, a lei vigente garante ao Estado a possibilidade de discriminar, punir ou ejetar, de distintas formas, qualquer estrangeiro que o Poder Executivo considerar como uma ameaça. Além de arbitrária, a lei da ditadura é obsoleta. Incompatível com o rol de direitos assegurados pela Constituição Federal de 1988 e com o direito internacional dos direitos humanos (p.3).
}

De acordo com o Estatuto, imigração e refúgio eram considerados como ameaça à segurança nacional, sendo casos de polícia. É por essa razão que qualquer solicitação de refúgio realizada em solo brasileiro sempre foi tratada pela Polícia Federal, e implicava em um longo e burocrático processo até a obtenção de alguma decisão oficial. Esse mesmo estatuto também vedava ao estrangeiro qualquer atividade de natureza política, tal como manifestar-se por seus direitos.

Em maio de 2017, depois de anos de tramitação e pressões dos organismos da sociedade civil sobre o Legislativo, a Presidência da República sancionou a nova lei de migração (BRASIL, 2017) 
Apesar do veto de 20 de suas propostas iniciais, trata-se de uma legislação moderna e avançada em relação às políticas migratórias. Em vigor, a lei dá ênfase à garantia dos direitos das pessoas migrantes. Segundo Ribeiro de Oliveira (2017), dentre os artigos da nova lei:

\begin{abstract}
Destacam-se, entre outros, os seguintes pontos: a universalidade, indivisibilidade e interdependência dos direitos humanos; o repúdio e prevenção à xenofobia, ao racismo e a quaisquer formas de discriminação; a não criminalização da migração; a não discriminação em razão dos critérios ou dos procedimentos pelos quais a pessoa foi admitida em território nacional; a promoção de entrada regular e de regularização documental; a acolhida humanitária; a garantia do direito à reunião familiar; a igualdade de tratamento e de oportunidade ao migrante e a seus familiares; a inclusão social, laboral e produtiva do migrante por meio de políticas públicas; o acesso igualitário e livre do migrante a serviços, programas e benefícios sociais, bens públicos, educação, assistência jurídica integral pública, trabalho, moradia, serviço bancário e seguridade social; a promoção e difusão de direitos, liberdades, garantias e obrigações do migrante; a cooperação internacional com Estados de origem, de trânsito e de destino de movimentos migratórios, a fim de garantir efetiva proteção aos direitos humanos do migrante; a proteção integral e atenção ao superior interesse da criança e do adolescente migrante; a proteção ao brasileiro no exterior; a promoção do reconhecimento acadêmico e do exercício profissional no Brasil, nos termos da lei; e o repúdio a práticas de expulsão ou de deportação coletivas (p.4).
\end{abstract}

Diferentemente de parte dos países europeus, o solicitante de refúgio no Brasil, munido de seu documento provisório - o protocolo ${ }^{36}$ - não tem nenhuma ajuda de custo específica, mas tem direito à obtenção de CPF e Carteira de Trabalho, isto é, pode ter conta bancária e trabalhar regularmente. Ademais, o sistema público de saúde e assistência brasileiro garante a universalidade de seus serviços, incluindo, evidentemente, pessoas indocumentadas.

A antropóloga Heike Drotbohm (2016), em estudo recente a partir de uma etnografia em serviços de acolhida brasileiros, descreve a realidade paradoxal das políticas de integração brasileira frente aos recém-chegados:

\footnotetext{
${ }^{36}$ Trata-se de um documento emitido pela Polícia Federal após a solicitação de refúgio. Documento oficial até a obtenção - ou não - do RNE (Registro Nacional do Estrangeiro) quando reconhecido o refúgio, o protocolo nada mais é senão um pequeno pedaço de papel impresso, com um número de registro, nome, nacionalidade e uma foto colada do refugiado. Esse será o único documento oficial do solicitante até obter sua resposta, o que pode levar anos. O ponto sensível é que um papel emitido de forma tão precária seja considerado o único registro válido para o sujeito. É o que garante seus direitos, e concomitantemente, desvela a precariedade de sua situação.
} 
No Brasil, como na maioria de outros países latino-americanos, as realidades dos migrantes são moldadas por um paradoxo peculiar. Por um lado, o discurso público implica uma atitude excepcionalmente progressista com relação à migração e aos direitos dos migrantes. Particularmente, na assim chamada crise migratória contemporânea, o Brasil aceitou muito mais refugiados do que qualquer outro país da América Latina. Por outro, a execução de políticas migratórias permanece frequentemente contraditória e arbitrária. Os estrangeiros que conseguem receber um visto e ganhar o acesso ao território brasileiro, aprenderão cedo que as cidades estão especialmente superpovoadas, burocraticamente complicadas e muito caras (s.p.).

Em São Paulo, tradicionalmente, duas instituições católicas humanitárias são referência de atendimento e acolhida a imigrantes e refugiados: a Missão Scalabriniana Nossa Senhora da Paz, conhecida como Missão Paz; e o Centro de Referência para Refugiados, da Caritas Arquidiocesana de São Paulo. As duas intervenções em saúde mental de que iremos tratar na presente pesquisa foram realizadas no interior dessas duas instituições.

Instalada no Brasil desde os anos 1940, e se debruçando sobretudo na acolhida e assistência a imigrantes italianos, a Missão Paz foi também pioneira no desenvolvimento de estudos migratórios ${ }^{37}$. Em 1978, sob sua coordenação, e ao lado de sua igreja, é fundada a Casa do Migrante, um abrigo localizado no bairro do Glicério, com capacidade para 120 moradores. Nesse período, a casa de acolhida compreendia os fluxos migratórios internos oriundos do êxodo rural, e o proveniente das ditaduras da América Latina. Atualmente, a Casa do Migrante segue sendo um abrigo de referência para o acolhimento de migrantes recémchegados na cidade de São Paulo, e a Pastoral da Missão Paz é reconhecida por prestar serviços de orientação jurídica, de assistência social e integração.

A Caritas, com seu Centro de Referência para Refugiados, há mais de trinta anos presta serviços de proteção, assistência social, saúde mental e integração para refugiados e solicitantes de refúgio. Atualmente, grande parte dos projetos do Centro são desenvolvidos em parceria com a ACNUR. No ano de 2015, cerca de 100 pessoas, entre refugiados e solicitantes de refúgio, foram atendidas diariamente no Centro de Referência da Caritas, em seus diferentes departamentos.

${ }^{37}$ Em 1969, a Missão Paz criou o Centro de Estudos Migratórios (CEM), além disso conta, até os dias atuais, com uma biblioteca especializada em migrações. 
Ambas as instituições, a Missão Paz e a Caritas são organizações humanitárias religiosas, católicas, mas não confessionais. Isto é, não têm objetivo de $\operatorname{converter}^{38}$ a população à qual presta serviço, e, por isso, trabalham e acolhem grupos de pessoas das mais diversas religiões ou culturas. Referência em serviços de acolhimento, integração e orientação a migrantes e refugiados, essas duas instituições católicas, como parte integrante da sociedade civil, são fundamentais para se compreender as modalidades de políticas de integração na cidade de São Paulo. Diante do fluxo acentuado nos anos de 2014 a 2016, essas organizações ficaram sobrecarregadas de demandas e sem possibilidade de uma expansão que pudesse responder às novas chegadas, e novas alternativas começaram a ser construídas em diversos níveis.

No ano de 2013, a Prefeitura de São Paulo, sob a gestão de Fernando Haddad, criou a Coordenação de Políticas para Migrantes, submetida à Secretaria de Direitos Humanos. Pela primeira vez, passaram a ser pensadas, no âmbito do Município, políticas públicas específicas para a população migrante na cidade. Como medidas novas, a Coordenação criou um Centro de Referência e Acolhida para Imigrantes - CRAI, visando atendimentos especializados em suporte jurídico, psicológico e oficinas profissionalizantes; assim como parcerias com abrigos públicos especializados para o acolhimento da população migrante. Em 2015, foi sancionada a lei $n^{\circ} 16.478$, de 08/07/2016 (SÃO PAULO, 2016) que instituiu uma política municipal para a população imigrante na cidade.

Essa mesma gestão implementou igualmente um Grupo de Trabalho na Secretaria Municipal de Saúde para pensar políticas de saúde voltadas à população migrante. As iniciativas desse projeto consistiram na realização de cartilhas sobre o funcionamento do Sistema Único de Saúde (SUS) em diversas línguas, tais como o créole, francês, árabe, inglês, espanhol, quéchua; assim como na implementação de rodas de conversas e dispositivos de sensibilização sobre questões migratórias em equipamentos da rede de saúde pública do município.

Paralelamente a essa iniciativa pública, desde 2012, formou-se a chamada Rede de Cuidados e Saúde para Imigrantes e Refugiados. Trata-se de um grupo não institucionalizado que se reúne mensalmente e agrupa representantes de diversos equipamentos de saúde,

\footnotetext{
${ }^{38}$ Todavia, o caráter não confessional não exclui a identidade católica das organizações. A direção de ambos os serviços é a cargo de padres, e símbolos católicos são presentes nas instituições. É importante frisar esse elemento, pois podemos notar que determinados grupos religiosos evitam, de forma sistemática, buscar auxílio nessas instituições, e tendem a recorrer a serviços - por vezes mais incipientes - em sua própria comunidade religiosa.
} 
assistência e pesquisa da cidade de São Paulo para discutir e trabalhar questões relativas à saúde e ao cuidado do imigrante e refugiado. Diante da insuficiência de políticas públicas que implementassem e desenvolvessem estratégias de integração correspondentes ao novo fluxo, profissionais dos diversos equipamentos públicos de assistência e saúde, tocados pela nova realidade que passou a interpelá-los, encontraram no âmbito da Rede um espaço de troca de experiências, discussões de caso, formação profissional e proposições de políticas públicas voltadas à saúde e ao cuidado da população migrante.

Perante esse contexto de implementação de novas políticas públicas, assim como das iniciativas de assistência da sociedade civil, é possível ver as novas formas de acolhimento e integração da nova população residente no país e mais precisamente na cidade de São Paulo se consolidando gradativamente, com alguns avanços e certos retrocessos. Ter em vista o histórico político de desenvolvimento dessas medidas nos informa tanto sobre os direitos e possibilidades de circulação e instalação de migrantes no Brasil, quanto sobre as linhas de governo e interesse de cada gestão política, e das lutas e pressões realizadas pela sociedade civil e militância migrante no país. 


\section{Capítulo 2}

\section{As clínicas e a escuta desterritorializada}

Partimos da experiência clínica em três distintos contextos de trabalho com pessoas migrantes. Distintas intervenções em diferentes instituições e cidades, mas que serviram como base para as experiências de campo da pesquisa. Três grandes contextos que convocam reflexões tanto sobre as especificidades próprias dos espaços, como dos lugares e circulações e posições da escuta do analista. O presente capítulo pretende, portanto, descrever os diferentes espaços clínicos sobre os quais o material da pesquisa está debruçado, para refletir concomitantemente sobre o dispositivo clínico empregado, tendo em vista elementos do encontro e dos posicionamentos clínicos sustentados nas diferentes situações.

Aqui, optamos por descrever o campo da pesquisa através de três cenas. A primeira delas se refere ao contexto de intervenção no seio do Grupo Veredas: psicanálise e migração no abrigo Casa do Migrante, no centro da cidade de São Paulo, entre os anos 2013 e 2014. A segunda cena consiste no trabalho realizado no interior da equipe de Saúde Mental do Centro de Referência para Refugiados da Caritas Arquidiocesana de São Paulo, também no centro da cidade, entre os anos de 2014 e 2016. E enfim, na terceira cena, abordamos a experiência de campo realizado na cidade de Paris, no contexto da cotutela de tese, em campos de refugiados a céu-aberto e centros de acolhida para refugiados recém-chegados, durante cerca de quatro meses entre 2017 e 2018. Três cenas em distintos contextos políticos, institucionais, diferentes enquadres e circulações, mas que se referem todas a intervenções de uma analista nesses espaços.

\subsection{Vivenciando a estrangeiridade na casa dos estrangeiros ou a escuta em uma casa de acolhida: cena 1}

Chegar pela primeira vez na casa de desconhecidos é uma experiência ambígua, pois somos permanentemente confrontados com a curiosidade pelas novas descobertas, mas igualmente com a angústia de vermos de forma tão nítida os contornos de nossa própria presença. Quando vamos à Casa do Migrante, nós que com o tempo passamos a nos chamar 
de Veredas $^{39}$, não levamos muita coisa senão nosso próprio corpo - que não é pouco, e que às vezes se faz sentir pesado nos momentos em que nos percebemos intrusos - aí me refiro aos espaços íntimos da casa, às conversas pelos corredores, aos grupos que se formam por afinidades, e a todos os modos de estar que acontecem espontaneamente e nos quais não fomos necessariamente chamados. Igualmente experenciamos, com frequência, a leveza dos momentos em que podemos flanar pelos espaços da casa, e simplesmente perambulando com nossa presença atenta e desatenta, tornamo-nos isca para qualquer atividade peripatética. Sustentando a estrangeiridade em sua potência, permanecemos disponíveis para o arrebatamento do encontro, para que um novo laço se estabeleça e para que um outro tipo de passagem por lá seja possível.

Para descrever essa primeira cena da pesquisa, gostaria de partir justamente da ambiguidade que se instala - como sentir - em nossa presença. Isto é, do constante sentimento de estarmos deslocados, desubicados de nós mesmos, e disso a possibilidade de fazer do estranhamento um lugar privilegiado de escuta, um ângulo sob o qual instalamos nosso ouvido-corpo e fazemos dessa posição uma presença possível. Posição analítica por excelência ainda que, nesse contexto, com alguns elementos a serem levados em conta. $\mathrm{Na}$ casa dos estrangeiros, somos nós que nos convertemos em estrangeiros sempre recémchegados (portamos outra língua, outra cultura, outros códigos, falamos as línguas estrangeiras com sotaque, titubeamos constantemente sobre nosso modo de agir e de nos portar), e se os moradores da Casa do Migrante vieram algum dia até o Brasil, somos nós que vamos permanentemente até eles.

Se de um lado, a posição analítica se configura pela estrangeiridade do lugar em que ocupa - pois é o analista que ocupa a outra cena, a da dimensão inconsciente - é no encontro com migrantes que esse mesmo lugar passa a ser corporificado pela estrangeiridade do próprio sujeito analista. Dizemos corporificado porque trata-se de elementos enunciados de externalidade que se manifestam através do corpo: língua, sotaque, cor de pele, vestimentas, trejeitos e impressões corporais presentes no corpo. Portanto, na relação que eventualmente se estabelece, são precisamente os traços de estrangeiridade do analista os que emergem através

39 O Grupo Veredas: psicanálise e imigração foi fundado por uma iniciativa de Miriam Debieux Rosa e Taeco Toma Carignato no ano de 2000 como um projeto de intervenção e pesquisa junto à população migrante. $\mathrm{O}$ grupo é coordenado pela Profa. Dra. Miriam Debieux Rosa e tem várias frentes de atuação em distintas instituições da cidade de São Paulo. O eixo de intervenção na Casa do Migrante é composto por um grupo de cerca de 10 terapeutas e 2 estagiários do curso de psicologia da PUC SP. Eu participo desse eixo como supervisora desde 2015, mas a experiência descrita remete ao período de 2013 a 2015, em que atuei como analista no grupo, frequentando a instituição Casa do Migrante semanalmente. 
do encontro com o outro. Esse é um elemento tão somente radicalizado no encontro com um estrangeiro, e que tende a ser uma notícia nova para o próprio analista recém-chegado sobre si mesmo para ser incluída como material de trabalho. Assim, a estrangeiridade vivenciada pelo analista através do encontro é tanto notícia sobre a posição ocupada no laço como ângulo em que uma escuta pode se instalar. Para a escuta de estrangeiros, sustentamos a posição privilegiada de um analista estrangeiro - e aqui, seja ele de qualquer nacionalidade, mas que possa fazer da estrangeiridade corporificada pelo encontro, lugar de sustentação da escuta.

Além disso, em cada ida semanal, uma nova ida se anuncia, isto é, a surpresa de uma outra Casa a ser desbravada, novas pessoas, grupos e famílias, novas nacionalidades, línguas, grupos, histórias e problemáticas. Igualmente, diante do desafio do novo, também lidamos com o durável vazio da possibilidade de nunca mais vermos e sequer termos notícias de alguém de quem vínhamos estando tão perto por algum tempo, daí também o fato de passar a sentir as ausências dos que partem do espaço comum.

Para muitas pessoas, a permanência na Casa do Migrante é só um ponto de parada a mais em um longo percurso errante entre cidades, países e continentes. Para outros, a Casa é espaço transitório de chegada, tempo contingente das primeiras cartografias da nova cidade, das primeiras palavras e frases em uma nova língua, da regularização dos papéis, das buscas de um primeiro trabalho e das possibilidades de viabilizar o projeto de ter uma própria casa. As realidades são múltiplas, mas grande parte dos moradores (passageiros) da Casa do Migrante são recém-chegados em terra de exílio.

Nesse sentido, pensamos nos modos em que nossa presença possa servir duplamente de inscrição das marcas singulares que portam essas presenças: na própria Casa (pois nossa intervenção clínica é na instituição) e na relação, entre nós, analistas, e eles, moradores passageiros. Imprimir marca consiste em pensar nas formas de singularizar a experiência e criar condições para que cada percurso, por mais efêmero que seja, possa ser historicizado, integrado e, portanto, significado, tanto no espaço como na relação.

Às vezes, alguns moradores partem porque entre vislumbres de outras oportunidades que se apresentam com urgência, decidiram retornar ou escolheram empreender-se em novas rotas; outras vezes, são decisões institucionais que impelem uma saída compulsória ${ }^{40}$; em

\footnotetext{
40 Aqui me refiro a situações em que o limite de tempo de permanência é excedido, pois ainda que não haja uma regra tão estrita, a permanência deve ser sempre provisória. Também existem situações em que os sujeitos devem sair devido a alguma infração de regras que impõe uma expulsão.
} 
ambas, nos debruçamos sobre as formas de fazer da passagem um percurso, do caminho uma trilha - aqui, pensando nas marcas, traços e pegadas que se imprimem no trânsito.

Pensamos na inscrição dupla: no espaço (Casa) e na relação que se tece (nós, do grupo, cada analista e morador) porque, de um lado, concebemos a intervenção na instituição, isto é, pensamos nas formas que a própria estrutura física da Casa possa servir de lastro para que os novos sujeitos que lá chegam façam de uma estrutura de passagem, um lugar de acolhida. De outro, pensamos nos mesmos modos de ancoragem e significação da própria história, porém agora tecida nos meandros de uma nova relação que se estabelece entre analista e morador. Nos dois âmbitos, podemos pensar em uma certa função-porto ${ }^{41}$ necessária para que o sujeito desembarque e aporte para chegar em um novo lugar.

Como veremos mais adiante, a chegada física em um novo país não coincide com um outro tempo de chegada do sujeito e seu percurso de deslocamento em terra de exílio. Há uma temporalidade própria do traumático (KNOBLOCH, 1998) em que o sofrimento do sujeito está imerso. Tempo irrepresentável do trauma que não se refere ao recalcamento como operação de defesa, mas à clivagem como modo de sobrevivência diante das experiências extremas vivida nas trajetórias de deslocamento. A presença-porto do analista, como veremos no terceiro capítulo, enquanto figura possível de posicionamento do analista, nos informa sobre o potencial de criar condições de ancoragem tanto de chegada em um novo contexto, como de significação da própria experiência.

Entretanto, poderíamos nos questionar sobre como falar concomitantemente de função porto e de modos de circulação de um analista que flana pelos espaços? Como articular a fixidez que aporta a imagem do porto, com a leveza e fluidez dos vários modos de circular pelo espaço? Pensamos que se trata justamente do diálogo entre os dois, da possibilidade de uma circulação tanto fluida quanto ancorada.

A ideia de porto que tomamos aqui nos serve de metáfora para pensar nas possibilidades de ancoragem, a partir da relação, de o sujeito desembarcar algo de si em terra de exílio. No entanto, não se trata de um porto fixo, imóvel e imutável no tempo e no espaço. Referimo-nos aqui à possibilidade de uma presença que sirva quase como um porto flutuante, esse que contém a fixidez necessária para a ancoragem, mas sem fazer disso presença permanente ou imprescindível. Nesse sentido, tomamos o porto como passagem e atravessamento mais do que como permanência perene. Aqui nos referimos, portanto, aos

${ }^{41}$ Trataremos mais aprofundadamente desse tema através de um caso clínico no Capítulo 3 desta tese. 
portos flutuantes, que dizem da presença-âncora (ou ancorada) do analista, e não dos portos cheios de musgos fixos e imóveis somente à espera de novos viajantes - porto nesse sentido é estrutura de defesa, é barreira e fronteira fixa entre o fora e o dentro. Debruçamo-nos, no presente dispositivo, justamente sobre as possibilidades todas de circulação e deslocamento.

Intervir no interior de um abrigo revela aspectos próprios se pensarmos em relação ao atendimento institucional em outros contextos (como hospitais, associações, etc), pois trata-se de um lugar de moradia e de convivência. Espaço de Eros, a Casa potencialmente figura como lugar de fazer laço. No que se refere a inscrição no espaço é importante sublinhar que os encontros clínicos na Casa acontecem, predominantemente, nos espaços de trânsito dos páteos, jardins e corredores. Nesses corredores, novos encontros, amizades e grupos se formam; na sala de TV, na biblioteca e na brinquedoteca, espaços de entretenimento, lazer e trocas; no refeitório, momento das refeições compartilhadas. De fato, no abrigo, quase tudo é compartilhado o tempo todo, desde as refeições, aos quartos, banheiros e espaços de lazer.

Diante disso, duas realidades nos interpelam com frequência: a das pessoas que, em crise, não conseguem fazer do espaço compartilhado borda possível de um lugar seguro - são os que não dormem (porque gritam a noite com seus pesadelos), os que não comem, ou não suportam estar em espaços comuns, os que deliram em persecuções com outros moradores, os que excedem com sua presença, porque não tomam banho, porque falam alto demais, porque acumulam lixo, porque insistem com modos próprios que destoam da coletividade instaurada; e a dos que uma vez tendo vivido o espaço transitório do abrigo, por vezes, excessivamente compartilhados, passam por ansiar por um espaço próprio, uma casa sua, fora da Casa do Migrante.

Converter o abrigo de passagem em uma casa de acolhida é, também, criar condições para que o espaço possa ser suficientemente seguro e protegido para funcionar como borda possível para que os mesmos persecutores que assaltam os pesadelos não estejam fisicamente presentes na Casa. Do mesmo modo, trata-se de pensar em um espaço em que o sujeito não seja somente mais um número (sem rosto e sem história diante dos fluxos e conglomerados migratórios, em cima de um beliche qualquer, comendo qualquer comida). Uma casa de acolhida, no contexto de sujeitos recém-chegados, é um lugar onde se possa ter um nome, onde se possa tanto aprender como ensinar novas coisas, espaço em que se possa imprimir marcas, singulares e coletivas, e que, desse modo, enquanto espaço, passe a integrar a própria história de deslocamento de cada um. Para isso, sublinhamos novamente que a intervenção é 
dupla, e na mesma medida que atua com os moradores, intervém com a instituição e seus funcionários $^{42}$.

Como vimos no capítulo precedente, a Casa do Migrante é um abrigo no centro da cidade de São Paulo com capacidade para 120 pessoas, entre homens, mulheres e crianças vindos dos mais diferentes países e contextos do mundo. Uma vez acolhidos na instituição, pessoas sozinhas, famílias ou grupos permanecem em uma temporalidade definida caso a caso, mas que varia, atualmente, entre dois a seis meses. Há alguns anos, antes do aumento das chegadas oriundas das "novas" migrações para o Brasil, o tempo de permanência na Casa, para algumas pessoas, chegava a durar até um ano. A mudança na temporalidade de permanência é sempre um fator a ser levado em conta em nossa intervenção, pois informa sobre os modos de presença de nosso grupo nos contratos terapêuticos que se estabelecem entre moradores e analistas. Refiro-me aqui às diferenças entre intervenções que possam durar seis meses ou aquelas que duram um ou dois encontros ${ }^{43}$. Ressaltamos igualmente todas as dimensões institucionais presentes na intervenção, pois, como dissemos, trata-se de uma intervenção com pessoas na instituição. Para compreender melhor, vamos às paredes que a cercam.

A entrada da Casa do Migrante é situada em uma rua quase erma, transversal a outras duas bastante movimentadas. De um lado, o comércio nas calçadas revela as novas presenças de migrantes que passaram a habitar a cidade; de outro, as dezenas de pessoas morando em baixo do viaduto também mostram, imediatamente, a pobreza e a precariedade de uma cidade excludente. Há, dessa forma, um contraste permanente entre aqueles que têm a Casa como moradia provisória e, a um passo dela, todos aqueles que vivem nas calçadas ${ }^{44}$.

Da entrada da rua, não vemos nada senão uma grande porta metálica, não há nenhuma inscrição ou indicação de onde iremos entrar, tampouco nenhuma campainha ou numeração, só uma porta de ferro em que há de se bater com alguma força. Uma vez do lado de dentro, passamos por uma portaria discreta e logo encontramo-nos diante de um grande pátio ligeiramente gramado e todo cercado por corredores que delimitam o quadrilátero de uma construção antiga. Eis o claustro, uma construção arquitetônica típica de conventos e mosteiros em que quatro corredores formam um quadrilátero circundando um jardim.

\footnotetext{
${ }^{42} \mathrm{O}$ grupo também atua com um grupo de funcionários paralelo ao trabalho com moradores.

${ }^{43}$ Questão insistente no grupo: o que se pode produzir em apenas um encontro?

${ }^{44}$ Certa vez, algumas crianças angolanas me contaram assustadas sobre a presença de "gatunos" que viviam vizinhos à Casa debaixo da ponte. Tinham dois medos, de serem roubadas por eles e de viverem como eles.
} 
Nos corredores e nos jardins há bancos e tanto no pátio como nos arredores da casa, os muros baixos onde todos sentam. Aos fundos, um jardim de onde se vê a paróquia, mais bancos, um convite a sentar, espaços de passagem e de troca. Há também um grande salão usado como sala de TV, uma sala para a biblioteca, uma brinquedoteca com jogos e brinquedos para crianças, e uma grande sala de refeitório ao lado da cozinha em que se prepara diariamente o café da manhã e os jantares de arroz, feijão e a mistura do dia. A Casa do Migrante é separada em duas alas de dormitórios, a feminina e a masculina. Cada uma ocupa um extremo do prédio de dois andares, e a entrada de diferentes sexos em cada ala é proibida. No caso de famílias, as crianças ficam na ala feminina, mesmo quando são acompanhadas apenas pelo pai.

Geralmente, nossa circulação compreende os espaços comuns e mistos da casa, mistos entre mulheres e homens, moradores e funcionários. Circulamos, perambulamos, mas também, em função de cada atendimento, elegemos espaços que possam servir de significação. Um determinado banco em determinado dia em determinada hora, um passeio pelo quarteirão, uma volta pelo jardim, alguma circulação pelo bairro, atendimentos individuais, atendimentos em grupo, muitas são as possibilidades. Há vezes que nos convidam a fazer uma refeição por lá, em outras utilizamo-nos da biblioteca ou da brinquedoteca, novamente, várias são as possibilidades de fazer dos espaços e da circulação modos de movimentação do sujeito e do analista. Novamente, perambulamos com uma presença disponível ao encontro e que, através da flanação atenta e desatenta tal como uma atenção flutuante "per via di levare" (FREUD, 1904/1969), tratamos de escutar os atravessamentos entre as estruturas da instituição e as novas presenças que a habitam. Assim, quando podemos nos instalar na inquietante estrangeiridade de estar lá, concomitantemente, instalamos nosso ouvido escuta(dor).

Introduzir o leitor na experiência na Casa do Migrante é um desafio complexo, pois o grupo é grande e tem uma larga história e, por conseguinte, acumula-se, ao longo dos anos, a herança de todos os que passaram por ali e, também, a cada ano, as marcas e impressões singulares que cada nova composição de grupo sedimenta. Começo, então, a tratar do dispositivo com um caso clínico.

Conheci Sandra na primeira vez em que fui à Casa, no início de 2013. Enquanto eu me apresentava junto com outros colegas a um grupo de pessoas, Sandra se aproximou de nós para contar de alguns problemas de saúde que estava tendo. Problemas no corpo, dizia que 
estava com uma ferida no braço, que aquilo lhe dava febre, que não estava bem. Esse foi nosso primeiro contato, fiquei imaginando que Sandra devesse saber pouco sobre a função de um analista, pensei, no entanto, que talvez o mais importante ela soubesse, havia ali, com aquelas pessoas, um espaço para falar de dor, de mal-estar, do que não estava bem. Isso já havia sido estabelecido antes de minha entrada, algum tipo de escuta específica estava garantida, e eu vinha desse lugar. Sandra vinha de Angola, chegara há pouco de Luanda com seu marido e três filhas ainda crianças. Falava o português das antigas colônias portuguesas da África. Do meu lugar, também de outra antiga colônia, contudo, pouco pude diferenciar as singularidades daquele sotaque. Mas foi sempre em português, esse português apropriado e apreendido, que nos comunicamos. Comecei a atender Sandra alguns meses depois, antes disso, apenas algumas poucas conversas sobre suas filhas que eu acompanhava paralelamente no grupo de crianças.

Um dia, enfim, entendi que havíamos começado um atendimento. Uma mulher que eu atendia há alguns meses havia ido embora da Casa, e Sandra vinha então me comunicar sua partida, e dizendo dessa partida, me disse sobre a dor de uma partida, da dor das partidas, de dores e de partidas - que estranha coincidência de sentidos tem o verbo partir em português. Foi quando então, pela primeira vez, Sandra me falou sobre um outro sentido, sobre o que era a dor da imigração e a dor de ter partido, falamos de perdas, e dessas novas, agora já no Brasil. E assim, a partir da narrativa de sua história em Angola, das dificuldades na Casa, no Brasil, das dificuldades de conseguir vir a ter uma casa, foram se configurando os atendimentos.

Aos poucos, através da circulação pelos espaços da Casa foram se construindo as aberturas de outros espaços na relação. De pé nos corredores, sentadas nos bancos da Casa, no vestiário em volta de muitas outras moradoras, em seu quarto, o espaço mais íntimo, foi se abrindo na relação um outro espaço, lugar em que se pôde falar de alguma coisa que não podia ser dita antes, e que, sobretudo, não podia ser dita a qualquer um. Paradoxalmente, vivendo em uma Casa onde tudo é compartilhado, pude logo entender que algo não podia ser - no entanto, comigo, que vinha de fora e, que ocupava um certo lugar na transferência, fora possível. $\mathrm{O}$ endereçamento tem aqui um lugar interessante e podemos pensar que qualquer palavra terapêutica parte de um endereçamento prévio, questão que retomaremos mais adiante. "Tenho muita dificuldade em guardar os nomes das pessoas, sempre me esqueço o nome de todos. Mas o seu eu nunca esqueci. Ana é o nome da minha tia, uma tia muito 
querida", disse-me Sandra assim que me viu um dia na Casa. Curioso dizer que não se lembra dos nomes. Com o passar do tempo, à medida que fui podendo adentrar em sua intimidade, descobri a existência de outros lugares, de outros personagens, de outros papéis. Sandra, em sua carteira de identidade, não se chamava Sandra, mas Sandrina. Sua filha caçula, de três anos, que todos conheciam por Laila, chamava-se, oficialmente, Lília Gisela; Clarice, a filha do meio, de sete anos, era Clarissa. Sandra também não era sempre chamada de mãe por suas filhas. Pedia insistentemente que a chamassem de Mana Sandra. "Mana de irmã?", lhe perguntei certa vez. "É assim que se chama as pessoas em Angola”, me respondeu. De fato, eu não sabia quase nada sobre Angola. A literatura de Pepetela, que era tudo o que conhecia até então, muito pouco me dizia sobre o que eu imaginava ser a realidade de Sandra em seu país de origem. Se no atendimento com pessoas da mesma cultura temos a impressão que estamos sob um solo comum, a partir do encontro com estrangeiros, vemos que o solo é tão somente uma ilusão. A diferença cultural parece assim radicalizar o desencontro repousado em cada encontro.

À medida que os atendimentos foram acontecendo, fui podendo perceber que diversos lugares não estavam tão claramente delimitados em volta de Sandra. Era ela irmã ou mãe? Sandra ou Sandrina? Era eu analista ou amiga? Essas perguntas foram retornando em diversos momentos e também a partir daí pude entender melhor sobre seu contexto. Até os dois anos de idade, Sandra morou na casa de seus pais. Até os sete viveu com a avó, e depois mudou-se para a casa de uma tia com quem viveu até ficar adulta. E por que tantas passagens, tantas casas? "Porque em Angola é assim. Quem tem muito filho entrega alguns para outras mães, que têm menos filhos, ajudarem a criar". Na casa de sua tia, longe de seus 11 irmãos biológicos, Sandra vivia com as primas, filhas dessa tia. "Em Angola não tem diferença quem é tia ou quem é mãe, é tudo igual, é como se todos fossem filhos". No entanto, Sandra me conta de situações vividas com muita mágoa em que sim, havia diferença entre os que eram filhos e os que eram sobrinhos. Ela, como sobrinha, por exemplo, não tinha o direito de entrar no quarto da tia, coisa que as filhas faziam.

Sandra já havia me contado da situação precária que viviam em Luanda, das terríveis condições na casa situada na periferia, sem luz, água encanada e numa realidade de profunda violência, a ameaça era constante. Um dia contou-me sobre roubos, assaltos, invasões de casa e homicídios em sua vizinhança. Ela e seu marido, no entanto, não eram militantes políticos, nem engajados em nenhuma organização, mas decidiram vir ao Brasil esperando escapar das 
condições de precariedade e violência no país e ansiando a possibilidade de viverem melhor.

Um outro dia em que cheguei para atendê-la, Sandra estava com muita dor de dente e, a partir disso foi me contando de como ela era forte, de como gostava de ser autossuficiente, e me dizia que não queria nunca depender de ninguém. Contou-me de seus 3 partos. $\mathrm{O}$ primeiro, de Mari, foi sua mãe que o fez. No segundo, de Clarice, como não pôde ser atendida no hospital, pariu sozinha, na calçada, em frente ao hospital. Disse que estendeu uma toalha e pariu, simples assim. "Foi melhor desse jeito, assim eu economizei", me disse. No terceiro parto, o de Laila, Sandra também deu à luz no meio da rua, mas dessa vez na estrada, a caminho para o hospital. Quando estava no trajeto, junto com seu marido, os dois brigaram e decidiram se separar no meio do caminho, foi então que ela teve as dores e pariu, completamente sozinha. Disse que diferente de suas irmãs, ela teve seus partos sozinha porque nunca gostou de pedir nada aos outros.

A ideia de ser sozinha era um elemento presente em sua história. Da infância e adolescência conta apenas de uma vivência solitária, sem amigos, sem poder compartilhar nada com ninguém, Sandra relatava diversas cenas em que chorava sozinha, pelos cantos da casa, sempre sofrendo muito. Se por acaso alguém perguntasse porque estava chorando, ela negava, dizia que na verdade alguma coisa tinha entrado nos olhos, e não estava chorando. Dizia ser muito tímida, e não queria, não conseguia compartilhar nada nem com os pais, nem com irmãos, nem com ninguém, sempre sofreu sozinha.

"Minhas filhas são diferentes de mim. Elas não são como eu era. E com elas eu converso". Mãe muito jovem, mana Sandra dizia que compartilhava todos os assuntos com suas filhas. E, de fato, muitos de nossos atendimentos se davam com as crianças em volta de nós, indo e vindo, participando ainda que deitadas em nossos colos, dormindo. Paralelamente ao atendimento que seguia com Sandra, mantive minha participação no grupo de crianças da Casa em que estavam também suas filhas. Em diversos momentos, os atendimentos atravessavam-se de distintas formas.

Em Luanda, Sandra exerceu diversas atividades ligadas ao comércio, trabalhava como vendedora ambulante e vendia alimentos e objetos. No Brasil, desde que chegara, não havia buscado trabalho. Esperava a carteira de trabalho, esperava regularizar sua situação, esperava conseguir matricular sua filha caçula, Laila, na escola, e, finalmente, esperava ter sua própria casa. No entanto, toda essa espera era vivida com muita apatia, desânimo e preguiça. Não podia arrumar uma casa porque só o salário do marido não era suficiente. Não podia trabalhar 
porque Laila não estava na escola. Sandra passava parte do dia deitada em sua cama, ou sentada nos bancos da casa, ou nos degraus em frente à paróquia quando a Casa passou a determinar a saída de todos os moradores durante o dia. Dizia não ter energia e nem vontade, passava o dia todo muito cansada e nos momentos em que não estava deitada e amparada pelas filhas mais velhas, ocupava-se de Laila.

Em um atendimento em que a filha mais nova estava entre nós, perguntei: "Laila, você tem vontade de ir para a escola?". Ao que ela, de pronto, respondeu: "Não". Fiquei intrigada com aquela resposta, pois ainda que vendo todas as irmãs e outras crianças da Casa na escola, Laila insistia em dizer que não queria ser matriculada. Era como se ali Laila respondesse pelo inconsciente materno. Sandra ainda não havia feito a travessia do luto de perder seu bebê para ganhar uma filha maior, já criança. Nesse sentido, Laila parecia responder à dificuldade de Sandra se estabelecer no Brasil e de poder pensar em seus projetos também individuais. Laila respondia a essa dinâmica se comportando de forma regredida, encenava constantemente a brincadeira de ser um bebê, deitava-se no colo da mãe durante os atendimentos, e simulava a tentativa de mamar nos peitos e chorar como um bebê, e constantemente colava-se ao corpo de adultos como se fosse um anexo. Era interessante notar que à medida em que íamos tentando elaborar uma separação, nos atendimentos, Laila tapava meus ouvidos, meus olhos, minha boca e dizia claramente que não queria que eu conversasse com sua mãe.

Em certa ida à Casa, Sandra contou-me que teve um sonho importante. Sonhou com uma mulher mais velha, não conseguia ver seu rosto, mas esta lhe dizia que alguém de sua família estava doente. Para Sandra, sonhos são presságios. Disse-me que tinha medo de sonhar. Diante desse aviso, contou ficar constantemente pensando quem de sua família que pode estar doente, sua mãe, seu sobrinho, algum irmão. Desde que chegara ao Brasil, nunca havia falado com seus pais. Apenas uma vez conseguiu fazer uma ligação e falou muito rapidamente com um irmão. Sobre esse temor, diz que tem uma saída: viver no mundo da fantasia. "Gosto de viver na fantasia. Não aguento lidar com os problemas, não aguento ficar muito tempo pensando nos problemas, então finjo que não está acontecendo nada e fico na fantasia", me contou. Quando estava muito preocupada, com medo, com problemas, comia compulsivamente. Quando estava mal, engordava. Se estava bem, quando não estava nervosa, conseguia administrar melhor a comida e comer apenas o que tinha vontade. Diante da possibilidade iminente de ter que sair da Casa (pois a família já estava na instituição há mais de 6 meses), Sandra preferia não pensar no assunto, mas passava quase todo o tempo na cama 
ou cuidando de sua filha como se fosse um bebê justificando assim a presença na Casa. Com todas as filhas na escola, ela não poderia passar o dia todo na Casa e teria que procurar um trabalho, pois marido e mulher trabalhando, poderiam fazer planos para uma casa da família.

É curioso notar que para Sandra sonho não era fantasia, mas presságio. No entanto, sonhar acordada é o que lhe permite escapar do que retorna nos sonhos, a realidade. Seriam esses outros nomes atribuídos a ela e suas filhas uma possibilidade de viver outra realidade? Fariam parte da fantasia que ela contava tecer? Essas eram algumas das perguntas que rondavam minha cabeça enquanto ouvia sua narrativa.

Eis que então, nesse mesmo atendimento, lhe fiz uma pergunta despretensiosa, sem esperar que isso reverberasse em uma revelação. Perguntei-lhe sobre escola, sobre sua vida escolar em Angola. Então ela me disse: "Isso é uma coisa muito difícil". E suspirou fundo. Sandra contou então que não foi à escola, era semianalfabeta, sabia apenas escrever seu nome e de suas filhas. Nesse momento, fui me dando conta de que aquilo que Sandra contara sobre ser analfabeta, havia operado quase como uma revelação. "Tenho muita vergonha disso. Ninguém sabe aqui na Casa. Você é a única pessoa que estou contando isso". E ela me disse sobre o sonho de um dia poder estudar. Disse, então, pela primeira vez, sobre seu grande sonho de vir ao Brasil, trabalhar, para poder estudar.

O analfabetismo era vivido por ela com muita dor, e frente a essa vivência envergonhada, Sandra disfarçava. E disfarçava bem. Fico pensando no quão custoso deveria ser o esforço em esconder algo tão presente, isso que diz da profunda incompreensão do mundo escrito. Terminamos nossa sessão ali. Estávamos, ambas, diante dessa revelação e da consequente possibilidade de sustentar um projeto de um dia poder estudar e voltar à escola. Fazer da terra de exílio a possibilidade de um lugar desejante parece ser uma passagem importante, pois não só permite ao sujeito se desidentificar com um lugar cristalizado de vítima das situações que lhe interpelaram, como da possibilidade de se reinventar, pelo desejo, de ser outro com novos projetos em nova terra. A passagem delicada entre migração forçada e desejada é um pano de fundo que nos remete às possibilidades de que o sujeito possa se apropriar das condições limites impostas pelas circunstâncias como potência criativa.

Na semana seguinte, quando voltei à Casa, Sandra não estava nos corredores, como de costume dos últimos meses. Encontrei-a num lugar inabitual, e ela me disse que estava com muita dor de dente, com dificuldade de falar e preferiria que nos víssemos outro dia. Na outra semana, também não a vi no lugar de costume. Estava na sala de TV, sentada em um canto. 
Propus irmos para o lugar de sempre e ela me responde: "Conversar o quê??". Disse que estaria lá fora, esperando-a e ela não apareceu. Na terceira semana, quando Sandra me viu chegando na Casa me disse: “Oi Ana, estou muito cansada, vou para meu quarto dormir". Respondi que tudo bem, mas consegui falar rapidamente:

EU: Sandra, fiquei pensando que naquele dia que a gente conversou, se não foi muito difícil para você falar tudo aquilo...

SANDRA: Difícil não, mas... eu não quero repetir.

EU: Tudo bem. Só quero te dizer que eu vou estar aqui, vou continuar vindo. E se você quiser falar comigo, me procure, tá bom?

SANDRA: Tá, eu sei, eu sei que você vem toda quartafeira. Eu também estou sempre ali no fundo. Tchau, vou subir.

Sandra foi embora do pátio, mas Laila e Clarice continuaram por ali. Curiosamente, pela primeira vez consegui ficar bastante tempo só com Laila, que me viu de longe e falou:

LAILA: Julia, Julia!

EU: Ah, quer dizer que eu sou Julia? E você? É a Clarice?

LAILA: Não.

Então começamos a brincar de nomes. Comecei a dizer vários nomes perguntando se algum deles era dela.

EU: Lucia? Maria? Julia? Cristina? Laura? Joana? Renata?

Josefina?

LAILA: Não. Não. Não.

EU: Laila?

LAILA: Não.

EU: Seu nome não é Laila? 
Quando perguntei isso, Laila SUBIU no meu colo, deitou em mim e continuou a brincadeira:

\section{LAILA: Meu nome é Gisela. \\ EU: Gisela. E quem é a Laila?}

LAILA: Não é ninguém.

Clarice se aproximou de nós. Ouviu um pouco o que falávamos e logo saiu.

CLARICE: E meu nome não é Clarice é Clarissa (e foi embora brava).

Laila desceu do meu colo, começou a desenhar em um caderno. Descobri que Laila tinha agora uma mochila de rodinhas cheia de materiais, e embora ainda não fosse para a escola, passava o dia arrastando a mochila pelos corredores da casa, e abrindo e fechando seu interior, brincando com as folhas e canetas do estojo. Agora Laila dizia querer ir à escola. Desenhando, começava a cantarolar a melodia de uma canção que me parecia familiar. Falava algumas palavras da música e cantarolava o resto. Então, eu me recordei da música e comecei a cantar junto. Quando cantei trechos que ela não estava cantando ela se surpreendeu:

EU: No ventre da mãe, bate um coração de Clara, Ana e quem mais chegar. Água, terra, fogo e ar.

LAILA: Ana?

EU: $\operatorname{Sim}$

LAILA: $E^{\text {v }}$ você

EU: Você sabe como é a história dessa música?

LAILA: Sei.

EU: É de uma mãe que canta para suas filhas, Clara e a Ana, quando elas estão na barriga.

LAILA: Ana? (e deu risada) 
Depois disso, se levantou e foi brincar com as outras crianças. Quando chegou o momento em que tive que ir embora, Laila não aceitou, começou a me morder, chorou muito, ficou com raiva, prendeu minhas mãos e pés e não me deixava partir. Só se tranquilizou quando a peguei no colo e fomos para um canto conversar. Sentadas em um banco, expliquei para ela que nosso tempo aquele dia tinha acabado, que ela poderia ficar brincando com as outras crianças, e que eu agora tinha que ir embora, que voltaria na próxima semana. Laila ouviu atenta, se levantou e saiu brincando com as outras crianças.

Algumas semanas depois, quando cheguei à Casa, Sandra veio até mim sorridente e disse: "Quero muito te contar uma coisa. Vem comigo". E foi me levando para seu quarto. "Voltei a estudar. Entrei na escola. Quero te mostrar meus cadernos". Sandra havia se matriculado no curso noturno de alfabetização de EJA (Educação de Jovens e Adultos). Mostrou-me todos seus cadernos, exercícios, contou dos colegas de classe, da professora, das dificuldades desafiadoras de letra cursiva, da ajuda que recebia de Mari, sua filha mais velha.

A partir de então, Sandra voltou a me procurar semanalmente para dividir preocupações sobre o que se passava na escola, sobre as novas pessoas que tinha encontrado, e sobre os planos de alugar uma casa, consolidava-se, enfim, o projeto de a família ter um espaço fora da Casa do Migrante. Poucas semanas depois, Sandra e sua família anunciaram a mudança. Despedimo-nos. A família havia encontrado uma casa, iam se mudar em poucos dias. Estávamos emocionadas, Sandra me deu um abraço, e também seu telefone e endereço em um pedaço de papel que atestava um lugar, uma nova casa e, agora, escrito por ela mesma.

Assim encerrou-se o atendimento com Sandra e suas filhas na Casa. Tratemos de pensar alguns elementos presentes no caso. É possível pensar que, em determinado momento, o sintoma de Sandra começou a exceder nos espaços da Casa: o tempo de permanência da família na instituição, o fato de ela não deixar os espaços da Casa durante o dia, ficar deitada o dia todo deixando suas filhas desassistidas, tudo isso interpelava a convivência na coletividade. Esses são geralmente os momentos em que a própria instituição convoca o grupo para uma atenção sobre determinado morador. Mas no caso de Sandra não foi exatamente assim, e foi somente ao longo dos meses de atendimento que fomos podendo dar sentido às formas de estar daquela família na Casa. Diante de uma presença que começava a ser excessiva na instituição, durante algum tempo, duas posições pareciam titubear constantemente, Sandra como mãe ou como amiga-irmã de suas filhas, e Laila como um bebê, 
ou com uma criança já de cinco anos.

Em um primeiro momento, Laila, a filha menor, parece ter vindo se anexar precisamente nesse ponto. Estar regredida era muito mais do que uma justificativa para Sandra ficar em casa se ocupando de seu "bebê", mas dessa forma Laila respondia também ao inconsciente materno sobre a impossibilidade de se haver com aquilo que era propulsor de seu deslocamento: o desejo de novos projetos, uma nova vida, os estudos, a escrita. É justamente quando a separação mãe/bebê começou a acontecer, que Laila vai podendo esboçar o desejo de brincar com outras crianças, ir à escola, ter sua mochila, desenhar em cadernos e, então, Sandra pôde enunciar um não-dito importante.

Aqui nos somamos à compreensão de Debieux Rosa (2001) daquilo que se opera à revelia do que é dito. Em uma dinâmica familiar, conteúdos não-ditos comparecem na subjetividade da criança, uma vez que a transmissão não está calcada somente na palavra, mas no desejo. Assim, a repetição revela não só um desejo inconsciente não elaborado, como algo presente do não-dito do discurso dos pais. Nessa compreensão, o silenciamento passa a ter “função de dupla alienação: mantendo o sujeito no refúgio narcísico e mantendo-o suspenso a um significante próprio e submetido a uma ordem instituída como condição para pertencer ao grupo familiar (p.131)".

Nesse sentido, Laila parece portar a vergonha de sua mãe analfabeta em um movimento em que não se autoriza ela mesma a ir à escola, pois trata-se de um sonho inconfessável de Sandra que, em um primeiro momento, não pode nem dizer e nem frequentar as classes. A partir da nomeação de Sandra sobre um projeto conflitivo, não só algo da ordem familiar se reacomoda em lugares mais apropriados de desejo, como o próprio lugar da mãemana Sandra passa a ser mais possível. Laila só se autoriza a dizer que deseja ir à escola quando sua mãe encontra uma via educativa para si própria. Mais apropriada de seu próprio projeto e, da possibilidade de converter a terra de exílio em lugar também propulsor de desejo, Sandra pode ser tanto mãe quanto mana, a seu modo. Em contrapartida, minha presença estrangeira à família dá lugar a um terceiro que possibilita tanto Sandra terminar de gestar para então parir seu projeto, quanto de sua filha Laila também poder deixar de ser bebê para desejar ser uma criança maior.

Podemos pensar que, ainda que recém-chegadas em terra firme, algo não tinha sido desembarcado e, encontrava-se quase como embargado, interrompido, e como se estivesse à deriva da possibilidade de aportar, Sandra passava seus dias na cama, apática e sem forças 
para se movimentar e Laila pretendia ser um bebê ansiando quase que voltar à barriga da mãe. Aqui retomamos novamente a ideia da função porto do analista. A presença de um terceiro cria condições de ancoragem, através do discurso e na relação, tanto de chegada quanto de significação e apropriação do próprio desejo.

Assim, pensar a intervenção na Casa permite não só a compreensão da dinâmica familiar, como no manejo da relação entre mãe e filha, Casa e família. O trabalho de nomeação do não-dito edificado na relação entre Sandra e Laila é realizado concomitantemente, e na medida em que o desejo de recomposição em nova terra pode emergir, mãe e filha podem retomar seus lugares e seus projetos. Diante disso, podemos ainda levantar mais uma pergunta acerca da questão do endereçamento: o que permitiu Sandra fazer aquela revelação para mim? Em um primeiro momento, uma resposta talvez óbvia: pela própria possibilidade de se produzir uma fala. Podemos pensar que o elemento que autorizou a emersão de certos conteúdos foi precisamente a possibilidade de que essa fala pudesse ecoar, ressoar. Mas não qualquer fala, e também não para qualquer pessoa. Transformar um relato em uma narrativa é inscrever a vivência na cadeia de uma história singular. Antes de tudo, para que haja narrativa, é necessária uma escuta. E isso diz de nosso lugar na instituição.

É possível pensar que justamente o fato de ter podido falar produziu uma mudança, pois falar para um outro, para esse escutador, (que na transferência não é qualquer outro) é também se ouvir, é disparar a experiência na cadeia de significação do mundo compartilhado, é inserir-se no espaço da narrativa para um terceiro e recompor, através do laço, um lugar coletivo. Nesse sentido, é possível pensar mais no efeito da fala de Sandra para si mesma, do que na intervenção da analista. $\mathrm{E}$ isso nos remete precisamente ao nosso lugar de escuta: o da possibilidade de fazer emergir uma narrativa.

Quando Sandra pôde me falar da experiência, e igualmente, se ouvir, houve uma mudança fundamental em relação a seu posicionamento. Isto é, a experiência transforma-se em narrativa, o acontecido inscreve-se em sua história singular. E essa mudança de posicionamento diz respeito à possiblidade que Sandra teve de dar voz, escuta e espaço para o que era silenciamento mortífero (ROSA, 2012) do vivido aprisionado sem significação.

Assim, de certa forma, Sandra pôde se reapropriar desse vivido, como responsável/narradora da própria história, para então, reassumir seus lugares a partir de suas próprias marcas. Ou, em outras palavras, para poder se relançar na vida, nesse país estrangeiro de exílio, sem que o medo do aniquilamento pela experiência sem significação fosse 
demasiadamente paralisante - ou simplesmente, a possibilidade de aportar para começar uma vida nova. Para além do encerramento ou condução de um caso, o atendimento de Sandra ilustra a aposta clínica na dimensão do desejo, de um trabalho na perspectiva das reinvenções e recomposições identitárias dos sujeitos no país estrangeiro. Vivenciando a estrangeiridade na Casa dos estrangeiros, partimos de uma intervenção que se faz valer dos múltiplos modos de circulação e externalidade do próprio analista para criar condições de deslocamento, circulação e desejo do sujeito em novo país.

\subsection{Entre necessidade e desejo, a escuta dos modos de resistência diante das retóricas da vítima e da temporalidade da urgência: cena 2}

"Ça va un peu" era uma frase comum de se ouvir em cada novo encontro com um refugiado na equipe de saúde mental da Caritas. Algum tempo depois, entendi que em países africanos francófonos essa é uma expressão para se dizer que as coisas não andam nada bem. De fato, se algo podia caracterizar nossos encontros naquele contexto era a gravidade e urgência dos casos. Ali parecia ser o lugar físico de enunciação da crise. Colapsos, gritos, choros convulsivos, com frequência nossa sala era submergida pela angústia.

No Centro de Referência para Refugiados da Caritas, nós que nos chamávamos de equipe de saúde mental, tínhamos uma sala, tínhamos horários e dias fixos a serem cumpridos, mas também toda a liberdade para inventar nossos modos de intervenção e circulação dentro e fora da instituição. Diariamente recebíamos pessoas através de encaminhamentos de outros profissionais da instituição, advogados, assistentes sociais, voluntários, mas também pessoas que procuravam um atendimento psicoterapêutico. Em média, recebíamos cerca de quinze a vinte novos casos por mês, de diversos países da África, Oriente Médio, alguns países da Ásia e da América Latina, alguns que atenderíamos semanalmente, durante muitos meses ou anos seguidos. Nossa equipe de saúde mental também era multidisciplinar e entre psicólogos, psicoterapeutas, psiquiatras e oficineiros pensávamos em intervenções criativas e conjuntas nas mais diversas línguas e contextos.

Dentre toda a complexidade institucional e o trabalho diversificado da equipe dentro e fora de nossa sala, pelos corredores e outros espaços da instituição, pelas ruas e pela região de centro de São Paulo, gostaria de eleger um ponto para desenvolver a reflexão sobre nosso 
dispositivo de intervenção. As modalidades de endereçamento da angústia pareciam se dar de uma forma distinta da cena anterior relatada na pesquisa. O nível de gravidade enunciado pelos casos se apresentava de uma maneira diferente. No âmbito dessa cena da pesquisa, partimos de um contexto de atendimentos de crise, de pessoas vivenciando o extremo da angústia e podendo enunciar a gravidade de suas situações na relação com nossa equipe. Assim, diante dessa nova forma de endereçamento, podemos nos aprofundar sobre alguns aspectos de nossa intervenção. Em relação ao dispositivo anterior, os atendimentos de nossa equipe na Caritas se configuravam como um lugar em que os migrantes vinham buscar um espaço de escuta.

Diferentemente da descrição da cena anterior, os modos de circulação das pessoas nesta instituição não eram de moradia, convivência, e estritamente um lugar de fazer laços e encontros em espaços de descanso, moradia, troca ou lazer. Evidentemente encontros se realizavam nas salas de espera e em alguns outros espaços, mas há uma questão a ser levada em conta; tratava-se de uma instituição em que as pessoas se dirigiam para demandar, no modo da urgência, coisas necessárias à subsistência: encaminhamentos para moradia, alimentação, assistência jurídica, auxílio financeiro, etc. Nesse sentido, dois elementos eram permanentes na circulação dos espaços da instituição; o lugar da vítima e o tempo da urgência.

Diante da gravidade da condição de vítima de situações extremas e também guiados pela temporalidade de uma urgência em responder às demandas, uma problemática importante parece se apresentar, portanto, a do sujeito reduzido à condição de necessidade. Isto é, a noção de necessidade (instaurada pelo lugar da vítima e pelo tempo da urgência) revela certa complexidade pois é tanto a condição para obtenção de assistência como uma forma de redução do sujeito em sua condição desejante. Vamos nos debruçar brevemente sobre cada um desses elementos.

Como vítima, aqui, tomamos a noção de um sujeito em condição extrema, elidido pela violência de um acontecimento, ou desamparado diante da precariedade de recursos e acolhimento, ou seja, de um sujeito instalado em um lugar de exceção e de demanda de elementos que se apresentam como necessários à reparação de um bem-estar de direito.

A noção de vítima é complexa e poderíamos problematizá-la ${ }^{45}$ através de diversos autores (FASSIN \& RETCHMAN, 2007); (CERRUTTI, 2007), mas elegemos em um

${ }^{45}$ Trataremos mais sobre a noção de vítima sob a questão do traumatismo no Capítulo 3 desta tese. 
primeiro momento esse termo por ser precisamente a forma como os próprios sujeitos tanto enunciam suas experiências, como a condição jurídico-moral-institucional ${ }^{46}$ em que são reconhecidos. Sendo assim, vítima é a forma pela qual grande parte dos sujeitos que, vivenciando as precariedades das condições de migração, nomeiam sua própria condição, e em contrapartida, a única modalidade em que podem ser reconhecidos - aqui pensamos no reconhecimento tanto no sentido de ter a experiência legitimada moralmente, como no reconhecimento jurídico institucional da presença no país de exílio. Portanto é como vítima que os sujeitos se nomeiam e são nomeados como possibilidade legítima de receberem assistência e direito. Problemática complexa - a de delegar aquilo que seria da ordem do direito à lógica da compaixão, esse parece ser um grande impasse em que as práticas humanitárias estão colocadas.

Sobre a urgência, pensamos nos modos em que a gravidade do sujeito instalado na posição de vítima convoca de uma temporalidade própria para aquele a quem se endereça. Diante da crise, trata-se de uma temporalidade de emergência. Paradoxalmente, diante da temporalidade da urgência, sempre longas esperas, filas intermináveis e em diversos contextos humanitários, vemos como a espera, diante da emergência, é sempre uma constante. Em referência à obra de Ticktin (2011), Saglio-Yatzimrsky (2015) aponta que as intervenções que exigem resposta rápida e de emergência instauram uma temporalidade específica que fomenta mais a lógica do caring (cuidado), do que aquela do curing (cura) de um trabalho de longo prazo. Isto é, centrado mais na permanência de uma condição de necessidade e demanda do que na perspectiva de uma intervenção longa visando uma resolução integral das questões apresentadas. Estruturadas enquanto retórica, intervenções de urgência, nesse sentido, prolongam em nome de um imperativo moral (SAGLIO-YATZIMIRSKY, 2015, p.179) a produção da assistência regida pela lógica compassional e não pela garantia de direitos.

Se a noção de vítima impõe ao sujeito certos impasses em relação à cristalização nessa posição e sua redução à condição de necessidade, também ela permite ao sujeito a obtenção do reconhecimento de suas experiências e o cumprimento de direitos (FASSIN \& RETCHMAN, 2007). Igualmente, as intervenções regidas pela temporalidade da urgência, na mesma medida em que reduzem as possiblidades de uma intervenção a longo prazo e tecida na singularidade de cada caso em perspectiva mais aprofundada, figuram também como

${ }^{46}$ Discussão a ser aprofundada no Capítulo 4 desta tese. 
possibilidade de responder a situações que efetivamente se apresentam como emergência. Segundo Knobloch (1998) crise é uma experiência em que o sujeito tende a se perder justamente naquilo que o diferencia entre a condição de sujeito e objeto, sendo assim intervenções de urgência também proporcionam condições de sustentação para a subjetivação em determinados contextos.

Desse modo, o ponto que gostaríamos de levantar para descrever essa cena da pesquisa diz respeito a uma intervenção clínica que possa colocar em relevo a sutileza do seguinte aspecto: ainda que as dinâmicas da lógica humanitária regidas por um ethos compassional venham corroborar, em alguma medida, com um lugar de redução do sujeito à condição de necessidade - e portanto cristalizado na posição de vítima e reduzido nas possibilidades de significar sua experiência - igualmente, essas mesmas dinâmicas podem vir a se tornar também instrumentos e modos pelos quais os sujeitos façam valer a reivindicação de direitos, justiça, assim como uma posição desejante no laço e em terra de exílio.

A questão parece então se formular a partir da seguinte problemática: até que ponto conseguimos pensar em uma intervenção clínica que produza efeitos de subjetivação - em que o sujeito possa ter recursos de significação da experiência e que possa se reapropriar de sua condição desejante em terra de exílio? Isto é, como pensar em significação da experiência em vias de reencontrar destinos mais criativos para a própria angústia, diante das modalidades humanitárias de assistência à vítima e regidas pela temporalidade da urgência? Ou ainda, como podemos escutar o sujeito para além do enunciado de pura angústia sem nos encerrarmos na mesma lógica que reduz o sujeito à necessidade?

De forma geral, pensamos que nos contexto de crise, as modalidades humanitárias de assistência e cuidado, regidos pela lógica compassional (FASSIN, 2010), parecem se desdobrar, com frequência, em dois extremos: em intervenções hiper-implicadas em que o analista (ou qualquer outro agente) se encerra no próprio fascínio ou horror presentificado pelo sujeito enquanto pura vítima; ou em intervenções automatizadas e desimplicadas como estratégia de defesa diante da excessiva carga de afeto no encontro com sujeitos em sofrimento extremo.

Tendo em vista essas questões, iremos ilustrar através de uma pequena situação clínica alguns dos direcionamentos suscitados nesse contexto. Partimos de um sentimento de malestar. Desde o princípio, a equipe de saúde mental foi tomada por um grande incômodo e que passou a gerar uma ordem de respostas das mais variadas, todas respondendo a esse 
sentimento de mal-estar. Passamos a observar uma situação que se repetia com frequência: agendamentos de horários com os analistas da equipe como forma de "furar a fila" de espera para outros setores da instituição. A fila de espera para demandas de assistência, demandas jurídicas e de integração, em alguns momentos, era muito grande, e podia significar, dependendo do caso, dias ou mesmo semanas de espera para sanar assuntos urgentes como: uma dúvida jurídica, a obtenção de algum documento, uma ajuda financeira, uma cesta básica, um encaminhamento para algum abrigo, etc.

Diante disso, passamos a observar, com frequência, pessoas que solicitavam agendamentos com a equipe de saúde mental como forma de adiantar o processo de demanda do que se apresentava como urgente. A aposta de alguns sujeitos parecia ser a de que nós, analistas, sensibilizados com a necessidade que se apresentava ali, iriamos interceder diretamente para agilizar o processo, junto aos outros funcionários da instituição, para que aquelas demandas fossem respondidas imediatamente. No entanto, frente a esse fenômeno, a equipe passou a expressar um grande mal-estar: em um primeiro momento, sentíamo-nos quase como instrumentalizados, diminuídos e usados para um outro fim. Como recusavam nossa oferta? Como nossos recursos de intervenção pareciam ser não só dispensáveis como reduzidos a uma manobra para obter outra coisa?

"Não podemos responder a essa demanda", pensávamos com frequência. Sentimo-nos logo ultrajados, e quase como se fôssemos enganados, lançávamos mão de respostas variadas que pareciam atuar o sentimento de mal-estar: anunciávamos que nenhuma possibilidade de furar fila existiria, tornávamos tiranos dos agendamentos ou abríamos exceções arbitrárias para determinados casos (sempre em função do quanto éramos tomados pela retórica da vítima e da temporalidade da urgência). Ainda que reconhecêssemos a urgência e necessidade das demandas que eram realizadas, através dessa "manobra" que passava por nós, sentimonos, em um primeiro momento, reduzidos à dimensão da necessidade e instrumentalizados para outras finalidades.

Algum tempo depois, em um trabalho de supervisão ${ }^{47}$ pudemos construir novas significações para esse fenômeno. Primeiramente, é importante sublinhar que aquilo que passamos a sentir, enquanto analistas, no interior de nossa equipe, como mal-estar, parecia se referir precisamente a um sentimento experenciado pelos sujeitos migrantes diante das

\footnotetext{
${ }^{47}$ Refiro-me aqui precisamente aos encontros de supervisão na ocasião da vinda da psicanalista Marie-Caroline Saglio-Yatzmirisky na instituição e sua intervenção.
} 
modalidades humanitárias de assistência. Demoramos a significar esse movimento. Aqui, referimo-nos às dinâmicas de instrumentalização, de redução dos sujeitos à condição de necessidade e objeto, tema que tratatamos mais longamente no Capítulo 1 da pesquisa. Assim, de algum modo, passamos a nos sentir, nós mesmos, em condição reduzida e objetificada diante da lógica instaurada pelas modalidades institucionais regidas pela retórica da vítima e da urgência. E sentindo-nos objetificados e instrumentalizados, atuávamos um mal-estar que também se expressava contratransferencialmente como raiva - pensávamos que talvez esses que pareciam nos enganar não fossem vítimas legítimas, pois a verdadeira vítima não simula nem protagoniza, ela apenas espera, suplica e recebe. Engolfados na lógica compassiva passamos a reproduzir, por atuação, a mesma retórica calcada na noção da vítima e da urgência sem conseguir vislumbrar intervenções que pudessem não só incluir essa dimensão em seu interior, como avançar para além dela.

Nos demos conta, assim, de um movimento particular: na própria "manobra" de fazer do agendamento de saúde mental uma forma de aceder mais rapidamente a um outro fim, um movimento interessante de agência e potência desejante do sujeito parecia despontar. Deslocamento importante de uma condição passiva para outra ativa, alguns sujeitos pareciam revelar possibilidades de agência diante das dinâmicas institucionais de redução à condição de necessidade, enquanto vítimas. Onde parecia haver a pura vítima que somente espera, suplica e recebe ${ }^{48}$, passava a existir um sujeito que não só circula nas malhas institucionais que produzem efeito de silenciamento e redução à condição de necessidade, como sujeitos que se utilizam ativamente desses mesmos recursos.

Pensamos que, ainda que envoltos pela retórica humanitária de assistência, nada nos permite dizer que as vítimas se considerem efetivamente enquanto tais (FASSIN \& RETCHMAN, 2007), e que não possam fazer das mesmas dinâmicas que seriam de redução, possibilidades criativas de potência e insistência da condição desejante do sujeito. Aqui, não nos interessamos somente às formas com que os sujeitos possam encontrar destinos mais criativos do que o unicamente o lugar da vítima diante da retórica da urgência, mas igualmente às possibilidades ativas de uso dessa mesma condição.

Sendo assim, tomamos o exemplo das filas e das "manobras" feitas por alguns sujeitos do serviço de saúde mental para a obtenção de direitos, mas podemos pensar em múltiplas

\footnotetext{
${ }^{48}$ E sempre deve receber tudo que vem como caridade na lógica compassional, quase nunca é possível negar sem que seja recebido como uma desfeita, o não quase não pode existir.
} 
formas de resistência e insistência do sujeito diante de dinâmicas totalizadoras e redutoras. Propomos pensar nas modalidades de intervenção que possam incluir tanto a temporalidade da urgência, como a retórica da vítima, mas precisamente nas formas em que o sujeito possa fazer disso não só uma circulação ativa de garantia de direitos, como a possibilidade de significação e desejo.

Nesse sentido, poderíamos nos perguntar: o que tem a psicanálise a propor como intervenção diante das demandas que se apresentam na ordem da necessidade (que frequentemente são materiais)? Como pensar em uma escuta diante de alguém que sente fome ou frio? Aqui pensamos justamente na escuta através da necessidade. Em intervenções que possam incluir não só as demandas materiais de urgência como elementos centrais, como em nos modos em que o sujeito possa se valer dessa mesma condição para insistir em um projeto de seguir vivo e resistindo à revelia das lógicas de aniquilação. Necessidade e desejo não são, portanto, dimensões dicotômicas e apartadas para o sujeito, mas modos dialéticos de insistência e resistência e que podem encontrar destinos mais ativos diante das redes de dominação.

Quando nos propomos a essa nova circulação diante dos mecanismos institucionais e das formas como o sujeito se apresenta nesses contextos, podemos pensar no que o psicanalista Georges Gaillard (2011) caracterizou como a criação de "pequenas ilhas de desaceleração" no trabalho institucional que permita espaços de autorreflexão e de autorepresentação do próprio trabalho. Esse foi precisamente o movimento de nossa equipe ao refletir diante do mal-estar sobre as possibilidades de outras significações do trabalho.

Interessamo-nos, portanto, por todos os modos de intervenção que possam se valer da escuta do sujeito para além do encerramento no fascínio ou no horror materializado na vítima. Pensar as modalidades de resistência às malhas de dominação ou do assujeitamento aos discursos que vedam a condição de sujeito (ROSA, 2012a) é nosso fio condutor, portanto. Assim, diante da crise trabalhamos na imediate $z^{49}$ da urgência da angústia e da necessidade, mas tratamos de não nos encerrarmos aí e de sustentarmos os modos de resistência e insistência do sujeito em seu desejo.

49 Sf. Relativo ao adjetivo imediato. Relação particular com o tempo-espaço na intervenção de um analista no front, diante das condições extremas do contexto. Registro relativo ao tempo de urgência convocado pelas condições do campo. Nas situações em que o analista se instala no front, trata-se da capacidade de incluir as situações de emergência como tempo de intervenção e operando através desse registro. Origem: Immediacy (Thomas Salmon, 1917) e Imédiatété (Davoine; Gaudillière, 2003). 


\subsection{Notas inquietantes das andanças em campos de refugiados em Paris: cena 3}

A terceira cena do campo da pesquisa se refere as minhas andanças pela cidade de Paris, tanto em campos de refugiados à céu aberto - isto é, barracas de camping montadas provisoriamente nas calçadas, embaixo das pontes ou viadutos, ou pequenos conglomerados de pessoas reunidas em espaços minimamente protegidos da chuva ou da passagem excessiva de transeuntes - como em visitas a um centro de acolhida da prefeitura da cidade para exilados recém-chegados ${ }^{50}$. Durante alguns meses, visitei semanalmente esses espaços, encontrei-me com pessoas, ouvi histórias, conheci pessoas e entrei em contato com uma realidade nova para mim, até então.

Já há tempos, eu vinha acompanhando pelos jornais e também por algumas publicações a situação dos exilados na Europa e particularmente na França. No entanto, a circulação por esses espaços me permitiu ver de perto alguns desses fenômenos amplamente noticiados. Assim, pude tanto observar o funcionamento de uma estrutura institucional de acolhimento e das instalações urbanas de pessoas sem-teto, como em paralelo, a partir das conversas com exilados recém-chegados, também compreender um pouco de seus percursos até alí.

O contato com essa realidade não se fez, todavia, sem fortes impactos. A cada nova incursão era possível sentir no corpo, no meu próprio corpo, o peso do atravessamento das questões que estavam permanentemente em jogo naqueles espaços. Com frequência, após essas incursões era preciso desmarcar todos os meus compromissos seguintes no dia. Ao sair desses espaços, eu sentia uma exaustão profunda e muitas vezes só conseguia responder a um impulso forte como um imã de ir para casa e dormir para me restabelecer das poucas horas passadas em cada dia. A partir dessa experiência, pude realizar pequenos diários de campo que me serviram de recurso, tanto de registro como de elaboração de incursões que mobilizavam afetos. Diferentemente dos outros casos relatados, os que apresentarei a seguir não se realizaram com uma finalidade terapêutica, no entanto, se referem às vivências de uma analista imersa no contexto das migrações. Para abordar, então, a terceira cena da pesquisa, insiro alguns trechos de notas realizadas durante o campo:

\footnotetext{
${ }^{50}$ Como dissemos previamente, essas visitas foram realizadas no contexto de uma pesquisa do grupo LIMINAL (https://liminal.hypotheses.org) no Centro de Acolhida. Durante alguns meses, nesse contexto, acompanhei o grupo de pesquisa nessas visitas e lá pude encontrar-me com pessoas e observar todo o contexto.
} 
Paris, entre outubro, novembro e dezembro de 2017: hoje conheci Camara, um jovem da Guiné que estava no Centro há três dias, conversamos no contexto de um translado ${ }^{51}$ para outra cidade, bem cedo em uma manhã muito fria já de quase inverno. Camara estava há três meses em Paris e todo esse tempo ele havia passado na rua. Na Guiné seu apelido era Rivaldo, como o jogador de futebol brasileiro dos anos noventa, e achando graça de eu ser brasileira, ele se aproximou para contar mais de si. Camara só tinha uma jaqueta e uma pequena mochila com todos seus pertences, e na mão uma pasta com todos seus papéis. Sempre os sem papeis com suas pilhas de papeis. Ali, ele estava esperando um ônibus junto a outras dezenas de pessoas sem ter a menor ideia de para que lugar da França ele seria transferido. Até subir no ônibus, depois de ter seu nome chamado, Camara não sabia para onde iria. Depois que o ônibus saiu, perguntei a um funcionário e me disseram que o ônibus iria para a região de Marseille. Está sendo levado em direção de onde veio, de onde chegou na França. Provavelmente nunca mais terei nenhuma notícia dele. Penso no périplo de ida, e depois a volta para o mesmo lugar, quase um Sísifo exausto.

Depois de três meses nas ruas de Paris, Camara só havia podido passar três dias no centro. Antes desses três meses na rua - onde conta ter sido agredido por moradores de rua que tentavam roubá-lo - ele esteve um ano no Marrocos, lugar em que viveu nas piores condições de trabalho até conseguir juntar dinheiro para pagar a travessia. Desde uma praia do Marrocos, às 4h da manha, Camara embarcou em um pequeno bote com capacidade para 50 pessoas, mas onde viajaram mais de 90 . Superlotado e sem um piloto que conhecesse de navegação, o barco se perdeu no Mediterrâneo e eles passaram mais de $14 \mathrm{~h}$ em alto mar, perdidos, à deriva. Camara conta que algumas pessoas se desesperaram e pensaram em se jogar, até que uma grande embarcação de alguma organização humanitária os encontrou e foram todos resgatados. Foi daí que ele chegou à Espanha, e, de lá, veio vindo de ônibus até Paris. Como essa história tenho ouvido muitas outras. Relatos de solidão e desamparo. Figuras do trauma e desespero. Relatos das travessias nos mares e no deserto, relatos dos abusos e explorações na Líbia e no Marrocos, na Hungria, na Itália, na Grécia, na França. Percursos de muita violência.

Em Paris, onde essas pessoas chegam com suas mochilas nas costas, os sacos de dormir (objeto de valor nesse contexto) e seus smartphones - os telefones parecem ser tanto o

51 Translado é o nome dos deslocamentos diários de migrantes que o centro promove para outros abrigos no interior do país. Deslocamentos, esses, sim, forçados em uma política de gestão migratória. 
meio de registro, compartilhamento e testemunho da experiência, como a possibilidade de fazer contato com os que ficaram e se referenciar nos novos espaços, item indispensável, e que, no entanto, causam certa confusão às populações locais insatisfeitas com as presenças que julgam indesejáveis e vem aí um objeto de luxo que não deveria pertencer àqueles reduzidos só à condição de necessidade. Smartphones nesse contexto parecem figurar nessa complexa confluência entre objeto de necessidade e de desejo que incide como os próprios deslocamentos.

Noutro dia, uma jovem eritréia me disse algo como: "não consigo nem contar o que se passou comigo na Líbia tamanho o absurdo que se passa por lá, depois disso nunca mais voltarei a ser a mesma". Os sudaneses e eritreus relatam com frequência seu percurso de deslocamento passando por esse trajeto. É extremamente árduo e muito longo. De seus países, as pessoas contam viajar em caminhões superlotados que atravessam todo o deserto do Saara. Hoje o deserto é considerado o maio cemitério a céu aberto, mais até que o Mediterrâneo. No cálculo do transporte de caminhão já se estima quantos morrerão. Os que sobrevivem - por sorte ou pelo quê? (pergunta que sempre vai insistir, como culpa e como enigma) - veem seus companheiros morrendo, de sede, de fome, e sendo deixados no deserto.

Após a travessia de semanas, chega-se principalmente à Líbia. Um novo capítulo. Pessoas escravizadas, violadas, extirpadas, gente convertida em coisa. Dos que conseguem sobreviver e insistir com seu projeto revolucionário uma nova travessia: a de barco pelo Mediterrâneo. Pequenas embarcações precárias, o mesmo cálculo dos que devem ficar pelo caminho. Há que se contar com a sorte? Contar com o resgate humanitário incerto? Na melhor das hipóteses, aporta-se em uma praia grega ou italiana. De lá, encarceramento, controle, digitais tomadas, violência policial.

Com sorte, mais uma vez, alguns saem depois de dias ou semanas ou meses, nova travessia: as fronteiras físicas. Leste europeu. Violência policial, frio, fome, barreiras, muros, cercas-elétricas, interdições de circulação. Alguns logram chegar a Paris, depois de muito caminhar. Enfim, o destino sonhado, o grande El Dorado: Londres. Nova travessia: Calais e o Canal da Mancha. Nas grandes capitais europeias, os recém-chegados encontram um novo tipo de violência: a da ostentação da riqueza, das noites passadas nas barracas em acampamentos urbanos, da polícia que rouba seus pertences a cada noite, os jatos de água, a hostilização dos residentes europeus, o frio, a instrumentalização humanitária, a espera sem fim, a impossibilidade de voltar. E Camara, recém-chegado a Paris, depois de três dias 
dormindo em um teto, é forçado a voltar pelo trajeto de onde veio, e sem saber, parte rumo à Marseille. Essas, sim, me parecem ser as migrações forçadas.

A natureza com que essas políticas migratórias europeias estão se constituindo tem marcado profundamente toda a trajetória dos exilados que conseguem se deslocar. Essa foi a realidade nova com a qual entrei em contato. Tudo isso me faz pensar nos exilados como sujeitos que, através de seus corpos, e reduzidos a seus corpos, desafiam sua própria sorte, e que diante da solidão e do desamparo se arriscam no limite da morte para não morrer no destino que lhes foi previamente oferecido. Insistem com presença furando uma lógica que quer fazer com que desapareçam. Insistem tal como um sintoma. Insistem com seus corpos que se fazem notar pelas lógicas invisibilizantes, com suas mochilas nas costas e seus smartphones. Nesse sentido, os percursos de deslocamento e a chegada aos países de acolhimento vêm marcar um segundo tempo de violência no significado de ser exilado na Europa: de um lado os fatores que impeliram à migração de seus países de origem, de outro os longos percursos e a chegada nos países europeus.

No capítulo precedente, tratamos dos discursos hegemônicos que culminam na produção da figura do migrante como indesejável. Discursos marcados pelo intricamento das políticas do muro, da indiferença e da necropolítica, os relatos e encontros com os exilados nas ruas de Paris trouxeram rostos, nomes e histórias das trajetórias vividas amplamente pelas populações que tentam chegar nos países mais ricos do globo. A miséria humana cruzou as fronteiras marítimas e veio desvelar nas capitais ricas e desenvolvidas o avesso de seu próprio funcionamento. A situação catastrófica dos exilados nas ruas de Paris parece funcionar como uma fotografia do fenômeno pós-colonial, da exploração dos países mais pobres e do racismo. A partir do relato de profundo desamparo e desespero dos exilados recém-chegados vemos a política sobre os corpos que não tem valor e que são tratados não só na lógica do deixar morrer mas deliberadamente - através da externalizações das fronteiras, das barreiras que não findam e de outras políticas - do fazer morrer desses mesmo corpos-restos. No entanto, na mesma medida em que essa presença tem efeito de denúncia de um funcionamento político da Europa com os outros países, também é prova da insistência e resistência de vidas que se fazem existir para além da exploração e das políticas de aniquilamento. Diante desses contextos, finalmente, nos perguntamos sobre as possibilidades de intervenção clínica. 


\subsection{Errâncias clínico-teóricas}

A partir dessas experiências clínicas, erramos por outras leituras e reflexões clínicas para tecer sentido aos dispositivos. Como vimos, a primeira cena se refere a uma intervenção nos corredores de um abrigo, a segunda a atendimentos em uma sala, já a terceira, às perambulações e encontros nos espaços comuns de ocupações de migrantes na cidade. O que norteia as três cenas é a escuta psicanalítica, porém, em contextos desterritorializados do setting tradicional, as diferentes situações demandam a fabricação permanente de elementos clínicos de intervenção. Por isso, outras leituras e elaborações clínico-teóricas nos servem como reflexão sobre os dispositivos empregados. Vamos a algumas dessas errâncias a partir de outros autores. São eles as figuras do clínico peripatético, do flâneur e do antropólogo.

O psicanalista Antonio Lancetti (2011), em sua clínica peripatética, apontou os modos de atuação de uma clínica praticada em movimento, fora do setting do consultório. Descrevendo sua larga experiência clínica em contextos urbanos com usuários de drogas, crianças e adolescentes em conflito com a lei e moradores de rua, Lancetti segmenta uma teoria clínica sustentada tanto sob a leveza da possibilidade de perambulação e movimento pela rua e por diferentes espaços, como na seriedade convocada pelo contexto de urgência dos casos. Assim, tomando de empréstimo a perspectiva aristotélica da ação peripatética, podemos lembrar sua etimologia: passear, ir e vir conversando. Trata-se, portanto, dos modos de fazer clínica em movimento.

Para Peter Pal Palbert (2008), a clínica peripatética proposta por Lancetti (2011) se refere às possibilidades de intervenção "fora dos espaços de reclusão convencionais, com o que se inauguram outras formas de engate terapêutico, bem como de conexão com os fluxos da cidade e da cultura" (p.12). Desse modo, através da perambulação em diferentes contextos, o setting analítico convencional é desterritorializado, e o analista passa então a habitar, com sua presença, o limite e a tensão (Ibden, 2011) das situações em que está inserido. Na clínica peripatética, não só o analista se desterritorializa de seu espaço de origem, como sustenta em todo seu movimento aquilo que Lancetti chama de trunfo da surpresa, o da possibilidade de ser constantemente interpelado - e, por que não, arrebatado - pela potência da imprevisibilidade do espaço e do sujeito fora da contenção intramuros.

Nas três cenas sobre as quais o material clínico da pesquisa está baseado, ainda que situado no interior de diferentes instituições, tratamos de refletir sobre a prática analítica que não tem como setting precisamente uma sala configurada como consultório, ou a própria 
instituição. A circulação por diferentes espaços da instituição, ou o trânsito pela cidade compõe o cotidiano de trabalho e ressoa nos modos de intervenção próprios do dispositivo. Mais ainda, movimento que se desdobra em outros modos de engate ${ }^{52}$ terapêutico e formas pelas quais a transferência se constitui. Clínica em movimento a partir da circulação e perambulação, pensamos nas diferentes posições do analista nas relações e espaços em que ocupa.

A partir das possibilidades peripatéticas de movimentação, podemos também pensar, nesse mesmo sentido, no Flâneur, amplamente conceitualizado por Walter Benjamin (1975) em seu texto "A Paris do segundo império em Baudelaire". Flâneur é a figura da perambulação que na modernidade, segundo Benjamin, a partir de sua postura diante da cidade, protesta contra a divisão do trabalho que não cessa de transformar pessoas em especialistas. Enquanto todos estão em seus postos de trabalho bem definidos, cumprindo suas funções e tendo uma circulação limitada e restrita à divisão do trabalho na cidade, o flaneur perambula pelos espaços públicos e pela multidão de outro modo. Nesse sentido, também não pensamos nossa intervenção clínica como especificidade ${ }^{53}$; fora dos muros do consultório, desvestimo-nos das insígnias que imediatamente indicam o lugar que ocuparíamos nos modos convencionais do setting.

O psicanalista peruano Miguel de Azambuja (2010), em Le detective-flâneur, estabelece paralelos interessantes entre a figura do flâneur e a posição do analista. Segundo ele, flâneur é aquele que realiza atividades quase clandestinas ou mesmo suspeitas, mas que permitem abrir novos espaços e passagens de fluxos na cidade. Relação particular à gravitação, o flâneur é aquele capaz de se desprender ou se desgarrar da fixidez do solo, guardando, no entanto, a firmeza necessária para sua circulação. Sobre isso, Benjamin nos fala sobre como o flâneur transforma a rua em seu próprio apartamento, e, dessa forma, sentese em casa diante das paisagens urbanas e das fachadas dos imóveis, assim como um burguês entre as quatro paredes de sua residência. Fora de nossos consultórios e espaços convencionais, pensamos aqui no dispositivo clínico que faz da circulação em diferentes espaços seu posicionamento específico e seu habitat de trabalho.

\footnotetext{
52 Como no livro "O engate" da sul-africana Nadine Gordimer (2004) podemos associar "engate" àquilo que engancha, que produz amarração e possibilidade de transferência na relação.

${ }^{53}$ Rosa (2001) fala na saúde mental não como especificidade, mas como direito.
} 
Flâneur é aquele que escapa à fixidez da residência, mudando a relação natural de gravitação com o solo, assim, não pesa no chão, ele flana: "leve como um pássaro e não como uma pluma [...] a pluma é às vezes levada pelo vento, submetida à sua força, enquanto que os pássaros traçam sua rota invisível aos nossos olhos" (AZAMBUJA, 2010, p.134). Figura porosa, o Flâneur está, dessa forma, constantemente em contato com o fora e o dentro (ibid). Assim como a clínica-peripatética, a porosidade do flâneur em sua circulação pela cidade (ou pelo páteo e pelos corredores da Casa do Migrante), também instaura um modo de circulação que permite a surpresa e o arrebatamento pelo encontro, pela imprevisibilidade, e nesse mesmo sentido, novas formas de engate em que o analista possa se tornar isca flutuante para uma nova relação terapêutica que venha a se estabelecer.

Em continuação a essas reflexões, há um outro elemento importante a ser levado em conta. Diferença cultural é elemento central na clínica em contato com pessoas migrantes de outros contextos. Trabalharemos alguns aspectos sobre as diferenças culturais e de línguas no capítulo 4 da pesquisa, mas no que se refere à discussão sobre o dispositivo, podemos pensar nas interpelações e diálogos entre a posição do antropólogo, ou etnólogo e a do analista nesse contexto. Diante da diferença cultural, somos interpelados pela curiosidade sobre outros modos culturais e pela dúvida constante em relação a se determinado traço que se apresenta se refere a fatores culturais de inscrição do sujeito no laço ou a modos singulares de sua própria história. Sendo assim, é diante da diferença cultural como elemento que radicaliza a diferença de qualquer encontro entre dois sujeitos, que algumas questões se colocam no que diz respeito a essas duas posições.

No sentido dessa clínica, antropologia e psicanálise parecem encontrar-se de alguma forma, porém em uma aliança não pouco controversa. Diversas são as abordagens clínicas que pretendem justificar essa aproximação. Marie-Cécile e Edmond Ortigues (1989) em seu estudo clássico sobre a experiência de um dispositivo analítico implementado por franceses em Dakar, no Senegal, sustentam a tese de que etnologia e psicanálise são disciplinas submetidas a exigências opostas:

O etnólogo busca informações. Com relação às populações a quem se dirige, o etnólogo é demandante. Para o psicanalista, pelo contrário, é a demanda emanando do sujeito que é a condição primeira indispensável para que se estabeleça uma situação analítica. O psicanalista recebe a demanda, escuta-a e tenta entendê-la, isto é, procura deixar que, pouco a pouco, da demanda manifesta surja o desejo latente (ORTIGUES, 1989, p.16). 
Nesse sentido, em o Édipo africano, a experiência dos psicanalistas franceses no Senegal é justificada por uma prática que dizem nunca haver ultrapassado as demandas clínicas, isto é, nunca movidos por uma curiosidade cultural, antropológica no andamento dos casos. Segundo os autores, as perspectivas psicanalítica e etnológica são incompatíveis na prática clínica, ainda que, muito frequentemente, em um segundo momento, sejam necessárias pesquisas etnológicas que enriqueçam o repertório do clínico sobre a realidade de sua escuta.

Em uma outra perspectiva, o psicanalista francês Olivier Douville (2014), em relação a sua prática clínica com sujeitos de outras culturas, sustenta a tese de que no interior da psicanálise freudiana repousa um projeto antropológico. Em seu livro Les figures de l'autre, Douville desenvolve a idéia de uma antropologia clínica, e sua tentativa é a de uma articulação profunda da epistemologia da psicanálise e suas possibilidades de diálogo com a antropologia.

\begin{abstract}
A técnica do cuidado psíquico com imigrantes e seus filhos afunda numerosos clínicos em um grande embaraço. Como acolher e ouvir as relações dos indivíduos ao mágico religioso nos corpos. Como ajudar os pais a se situar como sujeitos transmissores da lei e da proibição? Como se situar em relação à língua chamada "língua materna"? Trata-se de ultrapassar as polêmicas usuais associadas à redução da etnopsiquiatria a uma psicologia étnica, a fim de nos abrir a uma real clínica antropológica dos efeitos das migrações e dos exílios na vida psíquica e na transmissão dessa vida psíquica de uma geração a outra (DOUVILLE, 2014, p. 178).
\end{abstract}

A partir dessa articulação, alguns questionamentos são colocados pelo autor a fim de iniciar uma reflexão. Até que ponto é possível, enquanto clínico, situar-se em sua escuta para compreender os referenciais culturais do outro sem perder a atenção aos efeitos de linguagem próprios à fantasia singular? Se em um primeiro momento, os autores Marie-Cécile e Edmond Ortigues (1989) defendem uma prática clínica distanciada da perspectiva antropológica do pesquisador, para Olivier Douville (2014) a própria concepção de psicologia contém em si uma mitologia particular de cada sociedade. Portanto, não há psicanálise sem antropologia. Nesse sentido, a antropologia forneceria para a prática clínica elementos sobre a história das idéias: "nos ensinando muito sobre os contextos sociais e políticos que produzem as representações da vida psíquica, assim como as formas de sofrimento psíquico ou a dita doença mental são socialmente e politicamente determinados" (DOUVILLE, 2014). Na compreensão de uma antropologia clínica, toda a escuta em uma psicoterapia está 
condicionada a compreender os elementos culturais determinantes das representações psíquicas.

Em relação às duas abordagens, se para os autores franceses Ortigues (1989), psicanálise e antropologia marcam uma fronteira intransponível na prática clínica, uma vez que as disciplinas respondem a condições opostas: o antropólogo, ou etnólogo, é aquele que busca informações, e o clínico o que recebe demandas de pessoas que se dirigem a ele; para Olivier Douville (2014), em sua proposição de uma antropologia clínica, reduzir a psicanálise apenas a uma prática psicoterapêutica ou ao estudo de psicopatologia clínica seria negligenciar o projeto freudiano de "agregar elementos de verdade no plano da vida psíquica e da economia libidinal dos grupos instituídos, das multidões e das massas"(ibid).

Essas são, portanto, algumas das errâncias clínico-teóricas que compõe as reflexões sobre a prática nas clínicas desterritorializadas e a posição do anaista nos diferentes contextos do front. Como dissemos previamente, compreendermos o analista precisamente como aquele que ocupa o sítio do estrangeiro (KOLTAI, 1997). Assim, fazendo-se valer dessa posição, propomos a vivência da estrangeiridade como lugar de escuta, e nesse sentido, lançamos mão das figuras do clínico peripatético, do flâneur e dos diálogos com a antropologia para pensar alguns elementos sobre os modos estrangeiros de movimentação do analista nesses contextos. Nas clínicas desterritorializadas é o analista que se desterritorializa de seus próprios referenciais primeiros, buscando lançar-se em movimento a novas formas de engate a partir do encontro. 
Parte II

$O$ instante do front 


\title{
Capítulo 3
}

\section{Os estilhaçamentos do sujeito e alguns destinos}

\author{
Pesadez \\ conduzida pelo silêncio. \\ (Paul Celan)
}

No instante do front, pensamos a imediatez como o modo de intervenção para operar no tempo da urgência. É partindo dessa noção que pretendemos disparar a reflexão sobre as possibilidades de intervenção do analista diante da urgência convocada pelo contexto. Influenciados pela leitura de Davoine e Gaudillière (2006), partimos de um dos quatro princípios terapêuticos propostos por Salmon e Benbenishty (1986) em sua intervenção na guerra. Princípios que operam como pilares para se pensar o lugar e a intervenção de um clínico com sujeitos que se confrontaram com a catástrofe do estilhaçamento do laço, são eles: 1) Proximidade; 2) Immediacy; 3) Expectancy; 4) Simplicidade. Na dinâmica da transferência, a partir desses quatro princípios, Salmon define não só o sentido da intervenção, como o lugar do clínico diante do sujeito.

É, portanto, de Immediacy, um desses princípios resgatados por Davoine e Gaudillière (2006) como Immédiateté, como ato do analista que opera em sua intervenção tal qual uma "flecha linguagera que acerta na coisa Real ${ }^{54}$ lhe contraindo a entrar nas palavras" (p.324), que extraímos a noção de Imediatez para pensar a relação com o tempo de urgência convocado pelo front.

Desse modo, propomos Imediatez como uma relação particular com o tempo-espaço na intervenção de um analista interpelado pelas condições extremas do contexto. Registro relativo ao tempo de urgência convocado pelas condições do campo. Nas situações em que o analista se instala no front, trata-se da capacidade de incluir as situações de emergência como

\footnotetext{
${ }^{54}$ Não vamos desenvolver aqui o conceito de Real e seus vários desdobramentos na teoria lacaniana, no entanto nos serviremos de autores que se referem a essa conceitualização.
} 
tempo de intervenção e operando através desse registro. Se o traumático funda uma outra temporalidade, sem passado ou futuro e na suspensão do presente do acontecimento, a imediatez revela o modo pelo qual o analista atua precisamente no momento da crise e através da urgência. Trataremos de desenvolver essa perspectiva através dos casos e da discussão sobre o traumático como uma modalidade de sofrimento presente na clínica em contextos extremos.

\subsection{Cecil diante do desastre}

Era noite e eu andava pelos corredores do pátio da Casa do Migrante, quando vi uma mulher sentada sozinha em um banco, nossos olhares se cruzaram por um instante e fui saudada com um tímido "bonsoir", sem que eu tivesse anunciado que falava francês. Respondi o cumprimento e me sentei ao seu lado. Só fiz sentar - e em um gesto emprestei meu corpo à escuta ${ }^{55}$ - e logo Cecil encadeou longamente a primeira narrativa de todo o acontecimento que impelira sua vinda. Relato de desespero, Cecil ainda nem sabia quem eu era. Me perguntei se aquilo acontecia daquela forma pela natureza de transbordamento da angústia que fazia não haver nenhuma possibilidade de encontro com outra pessoa que não fosse marcada pelo relato do acontecimento, ou se pelos elementos enigmáticos da transferência, ela já havia identificado o suficiente para fazer da minha presença a possibilidade de compartilhar sua narrativa. Tratava-se de me contar sobre sua vinda junto a seu filho de oito anos para o Brasil havia poucos dias, desde Kinshasa.

Ali, Cecil me contou que na noite do 30 de dezembro de 2013, seu marido fora a um culto da igreja acompanhado dos três filhos mais velhos do casal, duas meninas e um menino, todos ainda crianças. Essa foi a última data em que Cecil viu seus três filhos e o marido. Essa também foi a data do massacre que produziu centenas de mortos e desaparecidos em todo o país; dos sobreviventes atingidos pelo evento, algumas dezenas puderam refugiar-se no Brasil. Empreendido pelas forças armadas do regime do presidente Joseph Kabila, o massacre visava responder a uma pretensa tentativa de golpe liderada pelo pastor Mukungubila. O marido de Cecil pertencia a essa mesma igreja protestante de oposição ao regime, e estava presente, junto com seus três filhos mais velhos, na ocasião do massacre na sede da igreja.

\footnotetext{
${ }^{55}$ Saglio-Yaztimirisky (2018) fala sobre a escuta como uma necessidade humana básica; tal qual comer, dormir, e nesse sentido sustentamos a intervenção nessa perspectiva.
} 
Diante das notícias que relatavam os acontecimentos mais atrozes e do desaparecimento de sua família, Cecil decidiu refugiar-se com seu filho mais novo, Fidel, na casa de vizinhos. Sabemos, repetidamente, através de inúmeros relatos, que mulheres cujos maridos foram presos ou desaparecidos frequentemente tornam-se alvo das mais diversas violências policiais e de milícias. Cecil foi rápida e bastante sagaz em se proteger a si mesma e a seu filho menor. Depois de alguns dias escondida na casa de vizinhos, e sem notícias de sua família, conseguiu através da ajuda de amigos do marido ir para o interior do país, onde pôde permanecer por cerca de três meses, escondida, até obter documentos e passagens para ela e seu filho embarcarem para o Brasil. Aterrorizada pela ideia de ser identificada, Cecil narrou, em seguida, o que sentira no aeroporto, coberta por um véu e óculos escuros, até conseguir embarcar no avião. Quando questionada pelas autoridades, disse que ia ao Brasil visitar a família e que retornaria em poucas semanas.

Cecil tinha os olhos estralados de medo, de pavor, exalava um hálito forte e engatava uma palavra na outra como quem procurava livrar-se de um peso implacável. Tive a sensação de nunca ter visto tanta angústia. Via uma mulher em desespero frente à suspensão produzida pelo acontecimento. Estávamos em março de 2014, três meses haviam se passado e a presentificação do acontecimento pela angústia reatualizava a cena naquele instante.

Depois dessa primeira narrativa, fez-se uma pausa. Decidi me apresentar, disse meu nome e o que fazia ali. Cecil me ouviu atenta e disse: "bom, então agora posso falar do que está acontecendo, não durmo há mais de uma semana, a cada vez que fecho os olhos me vêm cenas de tudo o que aconteceu, não paro de pensar em tudo, não consigo dormir, não consigo comer. Minha cabeça vai explodir. Estou enlouquecendo".

Loucura é a designação proposta por Davoine e Gaudillière (2003) para se referir aos sujeitos que se confrontaram com o extremo de si mesmos. Experiência de perda de si pelo colapso do laço, trata-se de sujeitos que enlouqueceram diante de situações de destruição. Mais além das estruturas psíquicas da psicanálise ou da gramática diagnóstica psiquiátrica, pensamos aqui nas vicissitudes da experiência de sofrimento de sujeitos que bordearam os limites do humano.

Nesse primeiro encontro, loucura é a forma pela qual é possível antever algo do estilhaçamento de Cecil diante do acontecimento. A imediatez do terror de Cecil em seu desastre convocou o próprio encontro a tornar-se também um lugar físico - a partir da relação - de continência da angústia. É a partir desse primeiro encontro, portanto, que se inauguram as 
condições para tornar a angústia algo palpável com algum outro. Assim, Cecil elege a mim na mesma medida em que eu mesma me empresto à imediatez convocada pela gravidade de seu relato. É disso que partimos.

Frente ao desaparecimento de sua família e à possibilidade de terem sido vítimas do massacre noticiado, Cecil escolhe pela sua vida e de seu filho, de quem não tira os olhos em nenhum instante enquanto estamos juntas, de quem precisa se assegurar a todo momento que está ao lado, em segurança. Cecil não podia dormir, não podia deixar de lembrar e de presentificar o horror a todo instante, impossibilidade marcada por uma dupla injunção: a de garantir a sobrevivência de seu filho mais novo em um novo país - sem tirar os olhos dele - e de garantir que a sorte dos outros três filhos não tinha sido abandonada.

Com o tempo, ao longo de nossos encontros, uma pergunta foi podendo ser formulada: e se eles estiverem vivos? E se ao menos um deles sobreviveu ao massacre e está perdido? Pergunta que fazia retornar o acontecimento, pois qualquer tentativa de averiguar essa possiblidade fazia eclodir crises de angústia que beiravam a dissociação ou culminavam em adoecimentos físicos graves. Averiguar se algum dos filhos estava vivo era também lidar com a possibilidade real de que podiam estar mortos. Intervenção delicada, o trabalho na imediatez remete a um fio - que na mesma medida que diz daquilo que liga um ponto ao outro, também expõe sua dimensão tênue. Entre a vida que resiste diante da morte, a crise parece irromper na relação como um fio que convoca o analista a trabalhar na delicadeza da escassez de recursos que se apresentam.

Cecil faz a escolha de refugiar-se, escolha que salva também Fidel, seu filho mais novo. Escolha que o salva, mas que naquele ponto ainda era preciso um passo a mais para não lhe aprisionar no acontecimento. Cecil não tirava os olhos dele, não podia permitir nenhuma distância, o que fazia com que Fidel estivesse todo o tempo ao seu lado em nossos primeiros encontros - momentos em que ela falava da família, dos três irmãos mais velhos de Fidel e de seu pai, desaparecidos. Nesses primeiros momentos, o menino ainda ouvia tudo aquilo calado, invadido também pelo excesso da mãe, mas gradativamente ia se distanciando com o corpo. E à medida que cada encontro ia se passando, cada vez mais que se consolidava um espaço entre mim e Cecil, Fidel ia ganhando mais espaço físico. Logo passou a brincar com as crianças em volta de nós - sempre à vista de Cecil, mas podendo estabelecer, lentamente, laço e convivência com outras crianças da casa. 
O enlouquecimento pelo colapso do laço convoca o analista a intervir diante de um contexto em que o sujeito se perdeu justamente naquilo que o amarra em seu entorno. É a relação com o outro que parece ter sido estilhaçada. Assim, pela ruptura do laço, a imediatez opera através da característica tênue que é o fio - esses fios esparsos, rotos e esfarrapados que tanto insistem e retornam como angústia e como denúncia da precariedade do sujeito em seu desamparo. Nessa perspectiva, é interessante notar como, na medida em que se consolida algum vínculo entre mim e Cecil, é Fidel quem ganha espaço físico em sua volta. Distanciarse fisicamente de sua mãe podia significar, enfim, construir seu próprio território em volta de si sem o medo aniquilante de desaparecer. Distanciar-se para poder brincar, para estar com outras crianças, para desbravar a nova casa em novo país, desbravar para, enfim, chegar.

Aos poucos, Cecil e Fidel foram podendo então chegar no novo país. Como já dissemos, os registros de tempo da chegada física em um novo país (no país de acolhimento) e o tempo de sentir-se efetivamente em um novo lugar não coincidem. A intervenção com Cecil encontrou lugar justamente nesse desencontro entre os dois tempos. Entre dois países, entre dois tempos, entre duas culturas e entre algumas línguas, o analista se vê aí convocado a se instalar, permanentemente, numa posição de entre dois. Desde o meu lado, a constância de minha presença fazia função de ancoragem, presença-porto, criando condições psíquicas para que fosse possível chegar subjetivamente a um novo lugar, em paralelo a possibilidade de fazer com que o tempo excessivamente presente e literal do acontecimento-extremo pudesse ceder espaço para aportar em um novo lugar.

Ancoragem é uma noção potente para esboçarmos algumas direções da intervenção. $\mathrm{Na}$ perspectiva do deslocamento, o instrumento âncora é aquele que permite fixidez temporária na posição que o navio pretende aportar para desembarcar. Não há desembarque minimamente seguro sem ancoragem. Provisoriamente, a âncora imobiliza a flutuação para aportar o barco. Dissemos sobre a presença-porto do corpo do analista, mas podemos pensar também sobre a função de ancoragem - que em português se faz ouvir (an)coragem, pela homofonia- do encontro entre analista e analisando tecido na transferência. Trata-se de criar condições de chegada para sujeitos recém-chegados que, acometidos pela presença transbordante do acontecimento-extremo, se veem sem possibilidade de uma chegada que urge por traçar uma nova cartografia de cidade, de língua, de cultura, de vida.

Os encontros com Cecil passaram a ser marcados pela constância semanal de uma oferta à escuta. Presença de corpo, todas as semanas nos encontrávamos no mesmo horário, 
quase sempre no mesmo banco, lado a lado sentadas no corredor do pátio da Casa do Migrante. Nosso contrato era de nos vermos uma vez por semana, sempre no mesmo horário, e de que aos poucos Cecil pudesse fazer dali um espaço possível de endereçamento para que aquilo que acometia todas as esferas de sua vida - os dias e as noites, a possibilidade de comer, de dormir, de estar nos lugares - tivesse um lugar de ex-istir, com alguma exterioridade possível.

A presença física dos atendimentos parece ter aí uma função importante, e aqui nos remetemos novamente a alguns aspectos da imediatez. Antes que uma demanda possa ser formulada, há uma oferta de escuta. Oferta que parte de diferentes dimensões: antes de mais nada, escuta como presença de corpo, um corpo que sustenta e que suporta ouvir a dor do indizível do outro, um corpo que não cede diante do horror, e que pela insistência e pela permanência, dá condições de emersão da palavra bordear o acontecimento. Um corpo que dá condições de reconhecimento do sofrimento em vias de se endereçar. Esse é o corpo do analista. Lembremos aqui de Ítalo Calvino, que, em "As cidades invisíveis", nos alerta que quem guia uma narrativa não é a voz, mas o ouvido, uma bela fórmula para pensar na potência do endereçamento. Para que se fale, antes de tudo, é preciso de um ouvido. E o ouvido está situado na presença do corpo-orelha-olhar do analista nos atendimentos diante do que a precariedade e a urgência do campo convocam.

Primo Levi nos contou de seus pesadelos em Auschwitz, em que ele ainda preso sonhava que estava em casa, junto à família e amigos numa mesa contando todas as experiências que lhe aconteceram e ninguém prestava atenção, pois todos estavam conversando, comendo, falando alto - e depois de nos disse que foi o que de certa forma aconteceu: quando ele se deu conta, ao sair do campo de concentração, que ninguém suportava ouvir seus relatos. O lugar do analista, fora do ordinário, é justamente o que suporta e sustenta essa escuta (não sem custos, traremos disso no capítulo 5).

Os atendimentos com migrantes, sobretudo os recém-chegados, portanto, trazem a peculiaridade de que antes que haja uma demanda de atendimento formulada, há, muitas vezes, a oferta de escuta do analista. Se voltarmos à cena inicial, veremos que narro minha perambulação (esse certo flanar-peripatético a que já nos referimos) pelos corredores da Casa. Perambulação atenta e desatenta, concomitantemente, essa que se deixa interpelar de forma cuidadosa e responsável por um sujeito em seu próprio extremo, mas sem fazer da interpelação captura bruta ou fascínio em que se cede diante do horror presentificado pelo 
outro. Assim, a partir da oferta de escuta, abrem-se as vias de possiblidades de endereçamento do traumático da experiência vivida. A partir da oferta de presença-porto do analista que coloca seu próprio corpo-setting em cena é que se dão as condições de ancoragem para algo do sujeito desembarcar e chegar. Ou ainda, que, em alguma medida, o sujeito possa se haver com a parte de si que escolheu por se deslocar e permanecer vivo.

É através do endereçamento que a angústia da efração do "por que", próprio do traumático, e da demanda de: como é que eu faço para apagar esse acontecimento? - pode se transformar na formulação de uma pergunta: "por que isso aconteceu comigo?" Pergunta sempre enigmática em alguma medida, mas que pode ser relançada. E, do: "por que isso aconteceu comigo?" para um sentido coletivo do acontecimento. “O que é que se passou em volta de mim para acontecer isso comigo?" É quando o acontecimento dá sinais de readquirir seu potencial político que diz do tempo presente.

Podemos pensar, a partir disso, em três momentos próprios dessa intervenção. Se em um primeiro tempo a vivência do trauma produz estilhaçamento e são as bordas do que faz unidade no eu que se elipsam, a categoria do 'por que' é refratada, o sentido é perdido. Invasão pelo acontecimento-extremo, são as palavras que se eclipsam através do silenciamento. No deslizamento entre o 'por que isso aconteceu?' para o 'por que isso aconteceu comigo?' parece haver uma nuance importante, essa que proponho considerar de um segundo momento, o de re-situar o sujeito no contexto do acontecimento.

Diante do excesso do acontecimento-extremo, é o sujeito que perde unidade para sobreviver. Lembremos aqui da metáfora ferencziana da Largatixa que, em perigo, renuncia a parte de seu corpo para seguir viva ${ }^{56}$. No deslizamento de uma pergunta que devolve o sujeito à cena: 'por que isso aconteceu comigo?', um lampejo de unidade do eu em vias de dar sentido ao acontecimento. Ainda que inexorável - pois parece sempre haver um resto enigmático em relação ao externo e à imprevisibilidade - a pergunta que o sujeito pode fazer sobre si mesmo na cena, dá condições para aquilo que poderia ser um terceiro tempo em relação ao vivido: 'o que é que se passou para isso ter acontecido comigo?'. Aqui podemos pensar na potência da reinscrição da dimensão coletiva para o sujeito outrora ejetado do laço, isto é, trata-se, de distintos modos, de dar significação política ao acontecimento.

Dissemos anteriormente sobre a outra temporalidade em que figura a perspectiva do traumático, tempo do irrepresentável, da clivagem e não do recalcamento. No entanto, através

${ }^{56}$ Trataremos adiante do conceito de atotomia de Ferenczi para pensar a problemática da sobrevivência. 
da figura de três momentos da intervenção: o primeiro do arrombamento da dimensão do sentido (o por quê), para a pergunta, "por que isso aconteceu comigo?", até um terceiro tempo em que é possível pensar em uma reinscrição coletiva do acontecimento em torno do sujeito; podemos pensar em modos de intervenção que sustentem a perspectiva da restituição do laço e da potência desejante de sujeitos outrora refratados pelas dinâmicas totalitárias de violência. Três momentos que operam na temporalidade suspendida pelo traumático e que convoca o analista a instalar-se no campo através da imediatez. Ou ainda, é a partir da possibilidade de intervir na imediatez que se criam as condições para que se instaure uma temporalidade de um trabalho mais longo.

Aos poucos, Cecil ia se integrando a uma nova vida. Fidel começou a frequentar a escola, Cecil aprendeu português, e alguns meses depois arrumou um emprego. Com o tempo, também foi tecendo um círculo de amizades e, a partir dessa rede, começou a procurar uma casa para alugar. Eis que surge então uma demanda, Cecil já não aguentava mais a vida do abrigo, estava cansada de comer todos os dias o mesmo arroz e feijão, passou a ansiar por cozinhar seu próprio foufou, para ela e para Fidel, e passou a desejar novamente ter um espaço seu. Espaço onde poderia ter suas próprias coisas, para, enfim, voltar a ter uma casa.

No entanto, com frequência, algum elemento do cotidiano fazia irromper a cena traumática novamente, como quando descobriu nas redes sociais que sua casa no Congo tinha sido destruída e no lugar havia sido construído um posto policial. De fato, agora, Cecil não tinha mais para onde voltar. Mas como ter forças para sustentar um projeto de uma vida nova, em terra de exílio, com a dúvida sobre o destino de sua família ainda em aberto? Ir atrás de sua família, saber o que tinha acontecido, apurar sobre o desaparecimento ainda não era possível.

Os caminhos para fazê-lo, no entanto, estavam dados. Mas simplesmente Cecil não conseguia ainda entrar em contato direto com essa questão. Fio delicado, sustentar o desejo de ter uma casa parecia significar a renuncia à casa que tinha no Congo, desejar um novo projeto era trair ou abandonar a sorte de sua família desaparecida. Era Fidel quem cumpria um papel central nessa transição. Por ele, Cecil decidiu se refugiar, foi também por meio dele que a integração em terra de acolhimento começou a se dar, foi levando ele na escola, que Cecil começou a conhecer o funcionamento de uma instituição brasileira e foi através das primeiras palavras que Fidel aprendia de português que ela viu a necessidade de aprender uma nova língua. Mas para que esse "por ele" não se convertesse em um peso implacável sobre Fidel, 
também era necessário garantir que distância e desaparecimento não incidissem como iguais, e de alguma forma, a presença-ausência dos encontros com a analista serviam de metáfora para esse movimento.

Passado algum tempo, Cecil conseguiu encontrar uma casa junto a outra família de congoleses. Decisão que revela uma escolha não fortuita, no país de exílio, Cecil restitui uma casa com uma família de congoleses. Essa notícia me foi dada por ela junto com a proposta de que seguíssemos os atendimentos em sua casa. Penso sobre esse pedido, não respondo imediatamente, mas sigo pensando que o trabalho de uma primeira transição estava em vias de se concluir. Uma demanda havia sido formulada, um sujeito de potência desejante voltava a dar sinais. O tempo da imediatez parecia ter se concluído.

Volto em outro momento para dizer que meu trabalho com ela na Casa me parecia ter sido o de acompanhá-la até aqui, e sinalizando, como uma cartografia, vamos traçando os tempos e espaços percorridos por nós. Novamente, penso no trabalho da ancoragem, importante para que algo da ordem da chegada possa ser desembarcado. Trabalho de criar referência, espaço simbólico, possibilidade imaginária de integração e algum tempo de esquecer. Cecil agora tinha um projeto, e estava mais apropriada do desejo de permanecer viva e proporcionar um projeto para seu Fidel. Conversamos sobre tudo isso, e ela me diz: "você é como se fosse uma pessoa da minha família... Como se diz a palavra que quero dizer? Que droga, é verdade, você não fala Lingala, esquece." E nesse último atendimento, me dou conta de que, pela primeira vez, Cecil fez uma pergunta sobre mim, quando me olhando fundo nos olhos, com um olhar de quem estivesse olhando ou reconhecendo pela primeira vez, ou um olhar de como quem agora olhava e me via, me perguntou: "Ana, você é brasileira?".

Trabalho de ancoragem através do reconhecimento, a direção da intervenção é a de fazer de uma palavra estilhaçada a possibilidade de enunciação de um sujeito desejante. Trabalho, portanto, de chegada entre dois tempos no registro da imediatez. Entre o tempo excessivamente presente das experiências mortíferas e destrutivas no país de origem e o dos imperativos de sobrevivência no país de acolhida. Temporalidade de uma intervenção clínica que não exclui a temporalidade psíquica do trauma. Trabalho necessário para que sejam constituídas as condições mínimas de integração em um novo contexto, trabalho de possibilidade de responsabilização do sujeito pelo desejo de permanecer vivo. 
É importante sublinhar que o movimento de saída do extremo da angústia não é o da perspectiva de silenciar o sintoma, mas o de escutar a crise em sua potencialidade. Ou em outras palavras, encontrar o que a loucura tem a dizer. Trata-se da possibilidade de emersão de alguma unidade subjetiva onde havia rombo e estilhaçamento. Que dos fios rotos, surjam novos laços e amarrações que permitam o sujeito tanto ficar, quanto circular. De que o sujeito possa se haver com seu desejo de permanecer vivo e reconstruir sua vida, de sustentar um projeto possível, sem que ele seja aniquilado pela culpa de estar vivo.

\subsection{Levy e o apequenamento pela culpa de estar vivo}

Comecei a ver Levy a partir de uma situação incomum: certo dia, recebo um telefonema de uma advogada da instituição me pedindo um suporte. Na ocasião da entrevista da assistente de proteção com o solicitante de refúgio, o que deveria ser o registro comum da narrativa de deslocamento, tornou-se insuportável. Ao escutar o relato, uma crise de choro irrompe na advogada, fazendo com que ela interrompesse a entrevista. Ao final, surpresa com sua própria reação, decide me ligar para pensar em como proceder para dar continuidade ao trabalho. Conversamos um pouco sobre o que se passou e me ofereço para estar junto na próxima entrevista. Foi então que conheci Levy. Sentei-me ao seu lado, me apresentei como psicoterapeuta da instituição e disse que estava ali para auxiliar no decorrer da entrevista.

Vi um homem apequenado por um acontecimento que não tinha lugar para ser, um homem esmagado pelo susto e siderado pelo evento que se fazia transmitir por outras vias que não pela palavra. A irrupção do choro da advogada testemunhava o irrepresentável no discurso dele. Levy só olhava para baixo, quase não sustentava o olhar face a face, falava com muito custo e muito baixo, era preciso se aproximar fisicamente para tentar decifrar as poucas palavras que saíam. A narrativa era difícil e seu corpo contorcido imprimia a dor de suas experiências. Com esforço e tempo, os fatos foram relatados e a entrevista chegou ao fim, sugiro a Levy nos vermos, agora só os dois, em um contexto de psicoterapia, digo a ele que as coisas que ele estava vivendo pareciam ser muito difíceis e que uma conversa em um outro enquadre talvez pudesse ajuda-lo.

Vimo-nos alguns dias depois. Levy também vinha da Republica Democrática do Congo, único filho homem entre muitas irmãs mulheres, órfão de pai desde muito cedo, vivia com a mãe, algumas irmãs, sua mulher e uma filha ainda bebê na periferia de Kinshasa, até se 
mudar sozinho para o leste do país para um trabalho provisório. Levy tinha estudado engenharia, mas depois de formado não encontrava trabalho. Único homem na casa, sentia o dever de prover o sustento de todos. Quando a situação financeira da família começou se agravar, Levy se mudou para Goma - notadamente conhecida por ser uma região muito violenta no leste do Congo - para um trabalho informal.

Instalado na nova cidade, Levy foi morar com um tio e dividia o trabalho com alguns de seus primos. Ainda nos primeiros meses de trabalho, Levy começou a presenciar desaparecimentos e assassinatos perpetrados por uma milícia local. Colegas de trabalho começavam a desaparecer estranhamente, até que Levy testemunha, de longe, o assassinato de um colega. Assustado e indignado com o que vira, e também temendo pela sua segurança e de sua família, Levy decide fazer uma denúncia sobre o que havia presenciado na delegacia de polícia local.

Atitude tanto irresponsável quanto ingênua, Levy parecia responder a uma ética que em nada condizia com as instituições do país, na atual situação política. Ato quixotesco, Levy denuncia o crime aos próprios criminosos, e o apelo àquilo que parecia uma instância de segurança passou a ser quase uma atitude suicida. Polícia e milícia naquela região representavam o mesmo grupo, um bando de homens que aterrorizavam toda a comunidade local através da violência. Na ocasião de sua ida para prestar queixa, Levy foi bem recebido pelos policiais que garantiram tomar providências sobre o que contara.

Pouco tempo depois dessa ida, sua casa é invadida. Levy estava no quarto quando ouviu o som de homens gritando seu nome. Escondido, consegue ouvir o que se passa no resto dos cômodos. Seu tio está na cozinha e um primo na sala. Novamente Levy testemunha um crime, e dessa vez como retaliação à sua denúncia. Do quarto, escondido em um pequeno compartimento, Levy ouviu seu primo ser morto e em seguida seu tio, que se recusava a dizer onde ele estava. Escondido até a madrugada, Levy consegue fugir de casa e deixar a cidade a pé. Após uma perigosa e clandestina viagem de volta a Kinshasa, Levy vai até a casa de um amigo que lhe aconselha a não voltar para casa. Poucos dias depois, Levy descobre que está sendo perseguido em Kinshasa por um grupo ligado à milícia de Goma. Sua família passa a ser ameaçada e o amigo que o abriga provisoriamente ajuda a esconder a família em outro local enquanto providencia a documentação para que Levy possa deixar o país o quanto antes. É nesse contexto que Levy chega a São Paulo, através da ajuda desse amigo e sem mais contato com a família que estava escondida em outro local e sem comunicação. 
Aterrorizado pelas mortes de seu tio e seu primo, e totalmente petrificado diante da possibilidade de sua família em Kinshasa: mulher, filha, irmãs e mãe serem vítimas de qualquer violência, Levy chega ao Brasil sem nenhuma possibilidade de se instalar. Alguns meses já haviam se passado quando comecei a ver Levy, às vezes mais de uma vez por semana. Nos primeiros encontros eu seguia com muita dificuldade de ouvir o que ele falava. Era uma voz embargada, um relato que saía como um canto chorado. Eu me via a cada vez tendo que me aproximar fisicamente para tentar decifrar cada palavra que saia com custo.

Quando começamos a nos ver, Levy morava em um pequeno quarto no extremo leste da cidade de São Paulo, trabalhava como faxineiro em um restaurante e não tinha força para mais nada além disso. Levy havia preservado uma funcionalidade que lhe permitia tão só permanecer um morto-vivo. Dormia mal, comia mal, buscava incessantemente, mas sem sucesso, notícias de sua família, as poucas palavras que sabia em português eram apenas o suficiente para manter seu trabalho noturno e não ter que contar nada de si para ninguém. Levy vivia isolado, passava todo o tempo livre deitado em sua cama, dizia não ter força para nada, não tinha estabelecido nenhum laço significativo com ninguém e passava todo o tempo martirizando-se por tudo o que havia acontecido. Levy sentia culpa por estar vivo. Culpa por ter partido, por estar vivo, por sentir que havia deixado sua família sem proteção, desse modo, mão se permitia aportar efetivamente em um novo lugar e sentir-se vivo com o excesso da ausência de todos que ficaram no país, os mortos e os desaparecidos.

As semanas iam passando, o vazio era permanente, mas Levy sempre retornava, vinha e tentava pronunciar palavras que bordeavam algo da dor que lhe esmagava. Certa vez, uma questão me ocorre: como era Levy antes de tudo isso? Do que será que ele gostava antes? Quais seriam seus prazeres e algumas de suas atividades que lhe proporcionavam alguma satisfação? Penso, intrigada, sobre isso, penso também no meu desejo em reativar o que via como zonas mortificadas em um sujeito apequenado pelo peso da culpa de estar vivo. Certo dia, relanço a questão. Uma hesitação, um tempo para pensar e ele me diz: "futebol, meu maior prazer era jogar futebol". Curiosamente, um novo capítulo entre nós se abre. Um homem aparece, o corpo se descurva e, aos poucos, a voz começa a sair, frases inteiras passam a ser pronunciadas.

Passamos a nos falar olhando olho no olho, não preciso mais me curvar para tentar decifrar cada palavra, pois Levy me conta com fluência em seu francês toda a história do futebol brasileiro. Vemos que o Brasil não é só terra desconhecida de exílio, e também figura 
em uma rede imaginária de desejo. Dessa minha intervenção, algum tempo depois, proponho um passo a mais, digo para que ele busque naquela semana algum lugar em seu bairro em que pudesse jogar futebol, sugiro tal qual uma prescrição médica, que dali uma semana voltasse tendo tentado jogar futebol algum dia.

Para minha surpresa, Levy encontrou em poucos dias uma quadra de futebol de várzea perto de sua casa, de onde passou a jogar assiduamente no grupo. A mudança foi rápida, e notavelmente um homem com vida, energia física, saberes, imaginação e algum desejo de viver voltou a aparecer. A transformação se fazia notar em como portava seu corpo. Passei a escutar uma voz forte no lugar do silêncio e dor de antes, e de novo Levy havia reencontrado a possibilidade de retomar alguma satisfação em estar vivo. Uma zona antes mortificada fora colocada em movimento. Agora ele dizia sentir com mais certeza de que deveria estar vivo para ainda poder ajudar sua família que poderia precisar dele. Levy pensava em voltar ao Congo, mas não tinha recursos e também tinha medo. Mas a partir daquela mudança, Levy passou a se aproximar da comunidade congolesa e tecer contatos que pudessem auxiliá-lo em sua busca.

A partir desse pequeno fragmento, gostaria de refletir sobre dois aspectos: em um primeiro momento, sobre o sentido de minha intervenção e, em seguida, pensar sobre o elemento de crise que irrompe no momento da chegada de alguns migrantes em terra de exílio.

Do ponto de vista da técnica, podemos igualmente nos perguntar: o que fazer diante dos chamados casos difíceis? Como pensar, por exemplo, nos conceitos pilares de neutralidade e abstinência frente ao extremo da angústia de um paciente? Casos graves, difíceis e tantas vezes considerados inanalisáveis, configuram situações que convocam o analista a pensar intervenções fora do ordinário. Profundamente comprometido com a cura e a compreensão dos chamados casos difíceis, Sándor Ferenczi revolucionou a técnica psicanalítica ao questionar alguns dos pressupostos da época. Em 1932, em seu Journal clinique, o psicanalista húngaro já expressava seu profundo mal-estar com um certo ethos analítico da época que em nada condizia com a realidade dos casos atendidos por ele:

Acolhe-se o paciente amavelmente, procura-se assegurar a transferência e enquanto o paciente se atormenta, fuma-se tranquilamente seus cigarro em uma poltrona, faz-se sob um tom entediante observações convencionais com efeito de frases prontas, ocasionalmente, dorme-se. No melhor dos casos, faz-se enormes esforços para não bocejar de tédio, ou ainda, esforçam-se 
para serem amáveis e compassionais (FERENCZI, 1932, p.34, tradução livre).

De forma irônica, o autor se dirige a uma psicanálise rigidificada pela teoria. Evitar que a análise seja uma nova repetição do trauma do paciente é uma preocupação central para Ferenczi. Os riscos parecem estar dados pela frieza, pela distância, pela falta de compreensão ou empatia. Para Ferenczi, o sofrimento do paciente pode se tornar mais agudo diante de uma intervenção não comprometida na singularidade que os casos de trauma trazem consigo. Isto é, trata-se da questão de que uma análise possa retraumatizar um paciente.

Debruçado sobre o atendimento dos casos que poucos analistas se comprometiam a receber, o analista húngaro teceu reflexões que modificaram a técnica psicanalítica e a forma como a teoria era concebida até então. Para Ferenczi (1932), o trauma tem caráter real, isto é, não se trata mais de afirmar apenas a realidade da fantasia, mas de pensar num trauma psíquico a partir de um conflito com o mundo externo. Em outras palavras, trauma seria a reação a uma excitação exterior ou interior de um modo autoplástico, que modifica a subjetividade, e não aloplástico (que modificaria a excitação). É, portanto, por reação à excitação externa que uma nova formação psíquica se dá, nova formação justamente através da destruição de partes de um eu anterior. Segundo o autor:

Um novo eu não pode ser formado diretamente a partir do eu precedente, mas a partir de fragmentos, estes produzidos mais ou menos elementares da decomposição deste (explosão, atomização). A força relativa da excitação 'insuportável' marca o grau e a profundidade da decomposição do eu. (FERENCZI, 1932, tradução livre, p.37).

É então sobre os estilhaçamentos do sujeito ou, segundo Ferenczi, do processo de atomização subjetiva, que se trata esse modo próprio de sofrimento. Dito de outra forma, traumatismo é um processo de auto clivagem narcísica, movimento de destituição subjetiva de parte do eu em detrimento da sobrevivência diante da ameaça de destruição. Uma parte do eu é mortificada e outra parte sobrevive ao traumatismo, parte essa que desperta tal como uma lacuna tanto na memória como na subjetividade, daí a clivagem, pois segundo o psicanalista húngaro, não somente a lembrança da agonia, mas todas as associações referentes a ela desaparecem de forma seletiva (FERENCZI, 1932). É nesse sentido, novamente, que podemos conceber o traumatismo como uma problemática narcísica, pois são os fundamentos do eu que estão ameaçados nesse modo próprio de sofrer. 
A partir dessa referência clínica, Felicia Knobloch (1998) se põe a pensar no que seria um tempo próprio do traumático, e dessa forma investigar em que ordem estaria registrada essa vivência no psiquismo. Traumatismo psíquico não é experiência inscrita no inconsciente, portanto não se refere a uma experiência recalcada, trata-se de algo que está fora do campo da representação. O traumatismo é, portanto, aquilo que é da ordem do irrepresentável e, nesse sentido, expressões corporais e manifestações psicossomáticas têm valor de recordação, pois exemplificam ou reatualizam o movimento de uma experiência não recalcada e, portanto, sem inscrição inconsciente.

Assim, a função do analista, através de uma presença compreensiva, benevolente e que favoreça o reconhecimento, é a de criar condições para que o paciente possa reviver os fragmentos mortificados que, em um segundo momento, passariam a ser integrados em um campo de representação. Preocupado com a técnica, Ferenczi vê os riscos de uma psicanálise que ignora o acontecimento real propulsor da vivência traumática.

Em sua polêmica conferência de 1933 “Confusão de línguas entre os adultos e a criança”, o psicanalista húngaro denuncia o quanto o fator real do acontecimento violento foi negligenciado pela psicanálise. É quando não há reconhecimento da experiência patogênica que uma sessão de análise pode se tornar uma repetição do trauma. Desmentido é, portanto, a noção Ferencziana para dizer do processo de negação da experiência vivida: ou do adulto que diz à criança que nada aconteceu, ou do analista que não reconhece a experiência. $\mathrm{O}$ desmentido, assim, não é apenas a negação do acontecimento, mas também a suspensão e dúvida da própria existência daquele que o experenciou (KNOBLOCH, 1998).

É nesse sentido que Ferenczi se propõe a pensar em uma intervenção clínica ativa que vise sobretudo o alívio do paciente em sofrimento. É a partir da urgência de seus casos graves que as proposições clínicas ferenczianas estão calcadas. Para isso, a noção de contratransferência é central em sua obra e, nesse sentido, o psicanalista húngaro é audaz em insistir na importância da análise do analista. Em sua clínica, ao se dar conta de que os pacientes percebem com extrema fineza e perspicácia aquilo que é da ordem dos humores, tendências, anseios, simpatias ou antipatias inconscientes do analista, Ferenczi propõe integrar no centro de sua intervenção a análise das resistências do próprio analista.

Admitir os próprios erros, analisar as resistências do analista junto ao paciente práticas consideradas inadmissíveis até então - são propostas clínicas de Ferenczi para uma 
intervenção que proporcione o alivio através do reconhecimento do sofrimento, e não de seu desmentido:

\begin{abstract}
A situação analítica, essa fria reserva, a hipocrisia profissional e a antipatia ao paciente que se dissimula por detrás dele, e que o doente sente com todos seus membros, não difere essencialmente do estado de coisas que outrora, isto é, na infância, lhe adoeceu. Nesse momento da situação analítica empurra-se o doente a reprodução do trauma (FERENCZI, 1933, p.38, tradução livre).
\end{abstract}

Comprometido em promover alívio ao sofrimento extremo de seus pacientes, preocupado em evitar intervenções violentas e que produzissem mais desamparo, Ferenczi se dirige a uma psicanálise ortodoxa e baseada nas reservas de neutralidade e abstinência do analista. Sinceridade, confiança e benevolência são, portanto, noções ferenczianas centrais para pensar uma posição analítica comprometida com a cura. Nesse sentido, para o autor, elementos como confiança são o que permite a construção de uma relação em que o passado traumático possa ser revivido, não mais como uma reprodução alucinatória, mas como uma lembrança objetiva. É, portanto, através de uma relação íntima de benevolência e do que Ferenczi chama de simpatia autêntica que se pode pensar em uma intervenção ativa junto ao sujeito.

Diante dos estilhaçamentos daquilo que faz função de narcisismo na tópica do eu, sustentamos uma intervenção que de um lado suporte a fragmentação subjetiva como modo de existência possível (KNOBLOCH, 2018), e, concomitantemente, possa também promover efeito de presença desejante do analista. Presença desejante em vias de reativar zonas mortificadas no sujeito. Com Levy, a questão que me ocorre sobre a possibilidade de ele desejar, na transferência, faz função de empréstimo de desejo. Empréstimo ou autorização, trata-se de uma intervenção enredada na transferência.

Na lógica da atotomia, o paradoxo em que o sujeito se encontra é o de manter-se vivo através da própria mortificação. Zonas mortificadas operam, concomitantemente, como zonas de resistência, mas não sem custos. Diante do abrupto do acontecimento-extremo, vemos os sujeitos que não só permanecem vivos, como têm a força de se deslocarem. Nesse ponto, uma consideração: tal como o processo de atotomia descrito por Ferenczi, pela clivagem ou fragmentação, o sujeito abre mão de uma parte de si em detrimento de outra para seguir tendo recursos de sobrevivência. O processo de deslocamento físico nos percursos migratórios impelidos por acontecimentos-extremos ilustra precisamente esse movimento. 
Percursos longos, árduos e profundamente perigosos, mas por meio dos quais grande parte dos sujeitos consegue, por estilhaçamento e fragmentação, manter-se no grau necessário de organização psíquica para sua realização. Sabemos disso justamente porque em tantos relatos diz-se de que parecia que havia um outro ali. Relatos dos percursos de deslocamento, não raro, são relatos que revelam o processo de clivagem pelo acontecimento.

Chegar fisicamente em terra de exílio poderia ser a representação de, enfim, haver alcançado alguma segurança e proteção diante do todo vivido. No entanto, é quando tudo parece estar normalizado e o sujeito poderia então empreender-se de fazer do deslocamento e da sobrevivência a possibilidade de ter um projeto de uma nova vida - novo país, nova língua, novo trabalho, novo eu em terra nova - é que a crise psíquica irrompe. Aqui chamamos de crise os momentos de dissociação, de adoecimentos somáticos graves, da angústia extrema e do sofrimento que invade todas as esferas e não permite ao sujeito nenhuma unidade para qualquer grau de pragmatismo necessário: suportar a convivência nos espaços comuns de acolhimento, aprender uma nova língua, estar em uma sala de aula, ir a uma entrevista de trabalho, caminhar na rua, dormir, comer, etc.

Referindo-se às reflexões do sociólogo Abdelmalek Sayad (1999), Saglio-Yatzmirisky (2018), sugere a existência de uma dupla ausência na experiência de chegada em uma terra que é simultaneamente terra de acolhimento e terra de exílio. Assim, inúmeras vezes, vemos que a eclosão da crise coincide com o momento em que o sujeito se instala no novo espaço, espaço de falta. Nesse sentido, a culpa sentida pelos sobreviventes que migram instala o sujeito em uma posição paradoxal: a de ao mesmo tempo ter logrado escapar da morte e de sentir-se culpado por essa mesma razão.

Culpa do sobrevivente é um tema amplamente trabalhado por Bruno Bettelheim (1989), que após a experiência de ter sido deportado para os campos de concentração de Dachau, e depois Buchenwald, passou a se questionar sobre as estratégias de sobrevivência em situações limite. Para ele, a sobrevivência consiste em dois processos que são estreitamente relacionados: o trauma original do impacto desintegrador do sujeito atravessado por uma experiência extrema e os efeitos posteriores ao acontecimento subjetivo de submissão ao terror. Diante da luta pela sobrevivência instaura-se a luta implacável com um mistério insolúvel: o de "Por que fui poupado em detrimento de outros?". Pergunta anexada à culpa irracional do sujeito ter sido poupado em vida, enquanto outros tantos, às vezes amigos e familiares, morreram no curso dos acontecimentos (BETTELHEIM, 1989). 
Referindo-se à experiência de sobreviventes de campos de concentração durante o nazismo, Bettelheim ilustra o conflito do sujeito culpado em vida:

\begin{abstract}
Uma voz, a da razão, tenta responder à questão de 'Por que fui salvo?' com 'Foi pura sorte, simples casualidade, não há qualquer outra resposta para a pergunta'; enquanto a voz da consciência replica: 'É verdade, mas a razão de você ter tido a chance de sobreviver foi que algum prisioneiro morreu em seu lugar'. E por trás disto em um sussurro poderia ser ouvida uma outra acusação ainda mais grave, crítica: 'Alguns dele morreram porque você os retirou de um trabalho mais fácil; outros porque você não lhes deu qualquer ajuda com comida, sem a qual você poderia possivelmente ter sido capaz de passar'. E há sempre a acusação final para a qual não existe uma resposta aceitável: 'Você se alegrou de que fosse um outro que tivesse morrido, e não você' (p.36).
\end{abstract}

Culpa de ter sobrevivido, culpa pelos que morreram pelo caminho, culpa pelos que ficaram, culpa por poder, enfim, estar a salvo e encontrar-se diante da possibilidade de uma nova vida. Em alguma medida, a irrupção da crise para muitos sujeitos parece ir de encontro com a possibilidade de então apropriarem-se do fato de estarem vivos e nesse processo fazer da sobrevivência, vida. Esmagados pela culpa de estarem vivos, pela vergonha do que precisou ser feito para sobreviver, a intervenção tem como sentido retomar a possibilidade de fazer da fragmentação novos modos de existência mais criativos e não congelamento, silenciamento ou paralisia diante do terror.

Sobre o sentido da intervenção, podemos pensar na presença do analista como aquela que cria as condições necessárias para a reconstituição do laço. Presença desejante, o analista faz aí função de mola que relança as significações do sujeito no sentido de recompor um lugar discursivo (ROSA, 2012a) outrora estilhaçado. Há, nesse sentido, uma intervenção que aposta na possibilidade de reconstituir, através dos modos de resistência do próprio sujeito, seu lugar no mundo. Autorização para seguir vivo, presença desejante do analista, trata-se dos modos de intervenção diante da crise.

Com Levy, Futebol pareceu figurar como um pequeno fio que, puxado, começou a esboçar o alinhavamento de novas montagens narcísicas possíveis. Também pelo futebol, Levy pôde não só retomar alguma dimensão de prazer e movimento em estar vivo de forma menos culpada, como reviver o exílio no Brasil em uma dimensão não só faltante, de impossibilidade, mas de alguma significação e reencontro com a representação do que era o Brasil antes do exílio. Brasil terra do Futebol, Brasil de Sócrates e Pelé, mas também terra do exílio marcada pela impossibilidade de retorno e suspenção da experiência, novos modos de 
significação puderam ser colocados em movimento. Na perspectiva da crise, diante do que Levy vive como a culpa de estar vivo, pensamos na direção de uma intervenção que possa dar sustentação à existência, para que de estar tão somente vivo, venha a se recompor um lugar possível, onde do estilhaçamento novas montagens de moisaicos sejam possíveis.

\subsection{Trauma e experiência}

Considerados casos difíceis, como Cecil e Levy, trata-se de mulheres e homens invadidos pelo extremo da angústia, pela eclosão do acontecimento no corpo, por alucinações. Perturbados por revivescências repetitivas que invadem o tempo presente ou perseguidos por seus torturadores de dia e de noite. Mulheres e homens cujos gritos noturnos de horror emergem assim que vencidos pela exaustão - como chamar de sono essa experiência que Freud (1900/1987) considerou sendo o sonho seu guardião? Sujeitos, enfim, portadores de uma memória sem trégua, memória que não se esquece, memória literal e sem seleção, tratase da pura insistência do acontecimento.

Enredados em uma constante paradoxal, referimo-nos aqui ao enlouquecimento próprio da destruição do laço e da transmissão humana: loucura que procura ininterruptamente - e por isso, enlouquecidamente - uma inscrição possível. Experiência fadada à repetição justamente pela inscrição ter sido impossível. Na mesma medida em que o laço é eclodido, não cessam, sem embargo, as modalidades que buscam sua reinscrição - mas que, no entanto, não advém à nenhuma forma possível se o sintoma não encontrar endereçamento. Se na insistência pelas vias de inscrição vemos também a resistência à aniquilação do sujeito, podemos pensar que a postura psicanalítica diante disso é a de escutar o que a loucura tem a dizer. Ou ainda, partimos da compreensão da loucura como experiência do sujeito.

Nesse sentido, para Davoine e Gaudillière:

Quaisquer que sejam as escalas: doméstica, pública ou política, a loucura traça o campo do Real que rompe o contrato social em um ponto não simbolizável, ao mesmo tempo em que nos oferece as ferramentas para sua exploração e sua nominação (p.75). 
Se o sujeito enlouquece diante da eclosão do laço social, é através da loucura que se apresentam as vias de significação possível. Loucura como resistência - tal como Bartleby e seu insistente : "I would prefer not" - trata-se de encontrar as vias pelas quais a experiência pode encontrar significação, trata-se da tentativa de restituir o laço diante dos modos de resistência e insistência da vida na ameaça de morte.

“Como é que eu faço para borrar esse evento da minha história?”, "como é possível apagar tudo o que aconteceu?", "quero voltar a ser quem eu era antes disso se passar", "quero esquecer tudo". Essas são algumas das frases proferidas com frequência nos atendimentos com migrantes recém-chegados. São sujeitos se referindo a situações precisas em que foram confrontados ao horror. Sujeitos que em suas trajetórias de vida foram atravessados pelo inexorável de uma violência. Sujeitos sobreviventes de situações em que não só estiveram diante da possibilidade iminente da morte, como também expostos a condição de objeto de crueldade da violência de outro homem sobre eles, ou situações em que estiveram eles mesmos diante de sua própria crueldade sobre um outro. As marcas indeléveis do acontecimento-extremo têm igualmente efeito na linhagem transgeracional subsequente pela sua natureza de repetição, que tal como uma pedra atirada em um lago, tende a ressoar e amplificar na cultura e na hereditariedade.

Acontecimento como desastre é a dimensão de que partimos para refletir sobre aquilo que chamamos de estilhaçamentos do sujeito e alguns dos seus destinos. Tal como a "noite à qual a escuridão falta, sem que a luz a clareie" (p.92), desastre é o acontecimento que irrompe fora da experiência e fora do fenômeno (BLANCHOT, 1980). Sem registro possível na ordem de significação, trata-se dos momentos em que a História em sua face mais extrema vem incidir em um outro registro, o da história, com h minúsculo. Somos todos sujeitos de nosso tempo até que História não venha esmagar a história, daí, tal como um meteoro, se dá a catástrofe e, eis que, paradoxalmente, esmagados pela História, os sujeitos são arrancados de seu próprio tempo.

Sujeitos estilhaçados, estraçalhados em decorrência do desastre, trataremos das vicissitudes do enlouquecimento do laço pelas guerras e violências que, em determinado momento, impeliram os deslocamentos em busca de sobrevivência e as possibilidades de resistência e de restituição de novos laços. Partimos da compreensão de Blanchot (1980) e Knobloch (1998) para pensar uma temporalidade do irrepresentável, um outro tempo instaurado pelas vicissitudes do desastre no sujeito, um tempo próprio das vivências 
traumáticas. Assim, compreendemos o sofrimento de um outro tempo que não o da representação. Acontecimento, portanto, que estilhaça, que rasga a temporalidade da representação e introduz novos modos de sobrevivência e resistência. Diante disso, propomos a imediatez como o registro temporal do analista em sua intervenção no espaço.

A partir desses dois casos clínicos, podemos refletir, portanto, sobre a dimensão do traumático como uma modalidade de angústia do sujeito diante do acontecimento vivido como desastre. Situado em outra temporalidade (KNOBLOCH, 1998), abordamos, através dos casos clínicos, trauma como terror, como enlouquecimento do sujeito pela ruptura do laço, assim como a problemática do sentimento de culpa pela sobrevivência, e dos modos de resistência e insistência diante da aniquilação pelo acontecimento.

Em um segundo momento, trataremos da questão do alastramento do conceito de trauma na contemporaneidade e algumas considerações sobre sua instrumentalização por via da patologização do sofrimento de sujeitos migrantes e da decorrente despolitização do acontecimento. Nesse sentido, pretendemos levantar, de forma geral, algumas indagações sobre as direções e o sentido da intervenção clínica com sujeitos imersos nesse contexto para pensarmos mais adiante algumas das direções da posição do analista instalado no front.

De saída, parece importante sublinhar algumas nuances das naturezas contingenciais daquilo que chamamos de acontecimento-extremo. É sobre a inferência do acontecimento na subjetividade que trata essa investigação, sobre o choque da transversalidade entre a (H)istória com h maiúsculo, esse da grande história social da humanidade em seu tempo, e a (h)istória com h minúsculo, da pequena história singular de cada sujeito, tecida na fantasia de seu romance familiar e comunitário. Nesse sentido, compreendemos como extremo a irrupção de um evento com potencialidade de desorganizar os referenciais simbólicos de um sujeito. A grande história faz marca, produz cultura e imprime o simbólico da subjetividade, porém, há os excessos. Excessos que também produzem cultura e imprimem marcas na subjetividade, mas justamente através da implosão de seus referenciais. Se os acontecimentos históricos podem ser compreendidos por seu potencial de invadir [no dicionário: penetrar em; assenhorar-se] (FERREIRA, 1999) a singularidade, os acontecimentos-extremos são aqueles que fazem da invasão um arrombamento. Trata-se daquilo que faz rombo no sujeito, daquilo que estilhaça as bordas do que faz unidade no eu. Em arrombar vemos a definição de: arruinar, humilhar e reduzir ao silêncio (ibid). 
Se em catástrofes ambientais tais como terremotos, furacões, tsunamis e enchentes, os sujeitos se veem confrontados à destruição e também à perda, são em eventos tais como a guerra, a tortura, massacres, genocídios, o estupro, que a violência se apresenta como um ato cometido por um sujeito diretamente contra outro sujeito. Trata-se da violência humana sobre outro humano. Se considerarmos essas situações de violência como acontecimentos extremos, podemos pensar na condição de extremidade humana a que se é levado frente a tais situações.

A separação entre as duas naturezas contingenciais do acontecimento extremo não é total, e aqui serve mais a fins didáticos ${ }^{57}$, pois, ainda que tangenciado por condições acidentais, catástrofes ambientais e seus impactos subjetivos nos atingidos estão inscritos na política do tempo histórico em que se produzem. No entanto, diferenciar minimamente duas naturezas de um acontecimento-extremo nos aproxima da dimensão traumática própria de uma violência humana perpetrada sobre outro humano e seus desdobramentos na subjetividade e no laço social. Nesse sentido, Marie-Caroline Saglio-Yatzmirisky (2018) propõe a diferenciação entre a vivência de um trauma acidental e de um trauma intencional. Como abordamos, eventos tais como o estupro, a tortura, vivências de guerra, perseguições e massacres são acontecimentos que, segundo a autora, quando incididos sobre o sujeito, põe em questão sua própria cultura. Isto é, trata-se de situações caracterizadas pela inversão ou destruição de regras geracionais e sexuais que são fundamentais e organizam o funcionamento da sociedade e a da família (SAGLIO-YATZIMIRSKY, 2018). É a eclosão da própria cultura.

Assim, podemos situar a dimensão política no interior do acontecimento que incide na esfera singular. Ou, em outras palavras, acontecimentos-extremos são os que se caracterizam pela colisão entre o íntimo e o político (D’ELIA, 2014) na vivência subjetiva. São, como vimos, acontecimentos que ameaçam as edificações simbólicas da cultura, pois tocam em seus interditos fundamentais. O extremo de uma violência perpetrada por um humano sobre outro tem impactos subjetivos indeléveis e, na clínica com migrantes, frequentemente estamos diante de sujeitos vivenciando o caos psíquico produzido como desdobramento do acontecimento.

Partindo da ideia de que não há homogeneidade naquilo que traumatiza (COSTA, 2013), situamos a compreensão do traumático não como o evento por excelência, mas por

${ }^{57}$ Pois, se tomarmos certos eventos como o de populações atingidas por barragens, enchentes, ou, à título de exemplo, a recente tragédia em Mariana- MG, vemos o quanto as condições materiais e históricas são preponderantes na produção destes acontecimentos, e mais ainda, nas condições de resgate ou recuperação das populações atingidas. Esses são casos em que vemos o resultado da ação humana em um sistema capitalista que visa a acumulação de capital em detrimento da precarização humana. 
seus desdobramentos psíquicos singulares decorrentes do acontecimento-extremo. Isto é, mais do que entender o trauma como evento, tratamos de compreender as vicissitudes pelas quais um sujeito foi elidido em decorrência do acontecimento. Essa tomada de posição frente ao traumático nos situa diante de uma acepção largamente difundida pela psiquiatria contemporânea e algumas correntes da psicologia, que iremos tratar a seguir, de compreender o trauma puramente como o evento violento, subtraindo, dessa forma, a singularidade de cada sujeito nos efeitos decorrentes ao fato, e, dessa forma, delegando ao sujeito uma posição cristalizada unicamente na figura da vítima de suas circunstâncias. Assim, podemos situar essa dimensão do traumático como um acontecimento psíquico derivado de vivências de situações extremas.

Compreendendo o trauma como acontecimento psíquico, portanto, nos interessa compreender as formas pelas quais determinado evento incide sobre cada um, perspectiva que ressalta de forma central a trama singular de cada sujeito: sua herança cultural, e as vicissitudes pelas quais alguma significação será possível ou não. Nesse sentido, parte-se de uma problemática narcísica, pois o traumático está situado na dimensão da ruptura dos laços sociais do sujeito e, dessa forma, o que está em questão são as funções subjetivantes do eu. Trata-se da eclosão, por clivagem, dissociação, ou desorganização, da dimensão subjetiva que faz unidade na tópica do eu.

Para Ferenczi, trata-se de uma experiência que vai de encontro ao corpo ou ao psiquismo sem que tenha havido uma preparação anterior, ou, nas palavras dele, sem 'contrainvestimento'; por isso sua ação é destrutiva, resultando em uma fragmentação subjetiva. $\mathrm{O}$ autor anota em 25 de março, em seu Diário Clínico, que, no plano psíquico, “a irrupção da violência, ou a ausência de um investimento sólido, provoca uma espécie de explosão, uma destruição das associações psíquicas entre sistemas e conteúdos psíquicos que pode estenderse até os elementos de percepção mais profundos" (1932/1990, p.23)..

Situações de barbárie tais como a guerra ou destruições em massa estão inseridas na ordem dos acontecimentos com potencialidade traumática (PESTRE \& BENSLAMA, 2011), e, que, nesse sentido podem desorganizar as fundações narcísicas do sujeito. Isto é, o traumático, enquanto vivência psíquica, vem elidir aquilo que produz unidade do narcisismo. Assim, segundo Pestre e Benslama (2011), são geralmente elementos exógenos, como os eventos históricos, os que incidem na singularidade de cada sujeito como tentativas de desumanização, justamente no sentido de ejetar o sujeito do laço. A partir dessa compreensão, 
procuramos destacar as formas pelas quais cada sujeito vai se haver com aquilo que em dado momento lhe foi cabido, pelas intempéries de sua trajetória.

Paradoxalmente, como vimos, trata-se do enlouquecimento próprio de uma busca de garantir a sobrevivência psíquica frente aquilo que visou destruí-la. Para o psicanalista Paulo Endo (2016), aquilo que funda o traumático: "não raro, é a urgência da tarefa de manter-se vivo diante de forças que impõem (e desejam) o aniquilamento do sujeito. Aniquilamento que está longe de se esgotar na ameaça física da morte"(p.9). Assim, podemos pensar no paradoxo em que está situado o traumático como problemática narcísica: a sobrevivência é garantida justamente através da desorganização das bases das funções subjetivantes do eu.

Desse modo, o enlouquecimento próprio do traumático como acontecimento psíquico pode ser compreendido como uma resistência extrema do sujeito à sua aniquilação. Para Miriam Debieux Rosa (2013), o "excesso de consistência do acontecimento - ou o embate com a violência obscena do Outro"(p.4) lança o sujeito fora da política e retira-o da experiência compartilhada que escreve a história do sujeito e da comunidade. É dessa perspectiva que partimos em nossa intervenção clínica. Direção que vise favorecer os modos de resistência à instrumentalização social (ROSA, 2012b) do sujeito na perspectiva de restituir a dimensão de experiência do acontecimento.

Sofrimento como resistência, pensamos nas modalidades de sofrimento do sujeito diante das tentativas de aniquilação. Assim, o corpo do analista faz função não só de continência, por sua unidade, mas é também presença desejante que investe narcisicamente (SAGLIO-YATZMIRISKY, 2018) o sujeito em sofrimento. No entanto, mais além do investimento narcísico pela presença do analista, pensamos de forma geral nas formas de restituição do laço e da dimensão coletiva do acontecimento, isto é, que o sujeito estilhaçado em decorrência do desastre possa recompor sua dimensão de experiência. Que o acontecimento possa readquirir sua dimensão de experiência no laço social.

$* * *$

Tendo em vista nosso posicionamento sobre a noção de trauma como uma modalidade de sofrimento de um sujeito diante de uma catástrofe, gostaríamos agora de nos situar em relação a outra concepção empregada com frequência em contextos semelhantes aos nossos. Tratando de outra perspectiva, abordaremos a problemática do alastramento da categoria de 
trauma no contexto humanitário para pensar em seus desdobramentos de despolitização do acontecimento e do esvaziamento da dimensão de experiência do sujeito.

No campo das migrações, a categoria de trauma é largamente utilizada para nomear as experiências de deslocamento. Quase consenso na literatura da área de saúde mental humanitária, trata-se da compreensão de que as experiências de precariedade às quais estão sujeitas pessoas em deslocamento aumentam as chances da incidência de um transtorno psiquiátrico:

Sabemos que ser um requerente de asilo, refugiado ou deslocado à força tem um impacto profundo na saúde mental, com um risco aumentado de desenvolver transtornos psiquiátricos comuns, como depressão, ansiedade, transtorno de estresse pós-traumático (TEPT), transtornos psicóticos, e também sintomas incapacitantes do estresse psicossocial. (ROSSEAU \& KIRMAYER, 2017, p.565). ${ }^{58}$

De forma geral, os processos de patologização da vida cotidiana acompanharam as formas pelas quais as experiências de deslocamento são compreendidas. Experiência, nessa concepção, não é mais tomada enquanto fonte de transmissão, tal qual Walter Benjamin (1936) formulou sobre a figura do narrador: “'quem viaja tem muito o que contar', diz o povo, e com isso imagina o narrador como alguém que vem de longe” (p.8). Tampouco experiência como o que Todorov desenvolveu em sua discussão sobre as descobertas que o eu faz do outro (TODOROV, 2008) abordando o verbo descobrir como ação intransitiva, e nesse sentido, compreendendo a noção de experiência e o relato da viagem como centrais nas vivências de deslocamento. Experiência como fonte de transmissão, consiste, para Benjamin ou Todorov, em pensar no movimento de trânsito próprio das migrações também como uma vivência que produz encontro, descoberta e que é, portanto, produtora de história e laço.

Nos discursos humanitários em que a categoria de trauma vem sendo cada vez mais adotada, a acepção é bastante distinta da que apresentamos anteriormente. Presença indesejável nos países mais ricos, não só grande parte dos migrantes passaram a ser tomados como ameaça e suspeição, mas a própria experiência do deslocamento passou a ser compreendida de forma hegemônica como experiência subjetiva de perda e falta. Mais ainda, migração tem sido cada vez mais tomada como evento traumático, nessa perspectiva.

\footnotetext{
${ }^{58}$ We know that being an asylum seeker, refugee, or forcibly displaced has a profound impact on mental health, with an increased risk of developing common psychiatric disorders, such as depression, anxiety, post-traumatic stress disorder (PTSD), psychotic disorders as well as disabling symptoms of psychosocial stress.
} 
Sobretudo em função da proveniência, mas também do momento histórico, os diferentes fluxos migratórios convocam diferentes reações e reflexões. Entre os anos 1930 e 1960, o mundo presenciou grandes migrações de refugiados italianos, húngaros, espanhóis e russos da Segunda Guerra mundial e Guerra Fria para diversas partes do globo. No entanto, foi a partir dos anos 1980 e 1990 que o deslocamento de populações africanas sobretudo para as antigas metrópoles, fez com uma nova percepção imperasse, e segundo o antropólogo Michel Agier: "as solidariedades políticas foram substituídas pelas inquietudes difusas suscitadas pelas imagens de massas em movimentos, africanos e orientais, indivíduos em errância, aterrorizados, vítimas anônimas percebidas também como excessivos e indesejáveis" (2012, p.31).

Tendo em vista esse contexto, podemos pensar que os processos de patologização da experiência migratória são confluentes com as novas modalidades de percepção das migrações como ameaça e excesso. Isto é, trauma, nesse contexto, é utilizado como diagnóstico e se inscreve, precisamente, na produção de discursos patologizantes sobre a migração na ordem de uma economia moral que essencializa sujeitos provenientes de determinadas partes do globo. Nesse sentido, podemos nos perguntar, a propósito do alastramento da categoria de trauma no campo humanitário, o que a produção desses discursos revela e esconde em um mesmo processo? Isto é, o que a proliferação da noção de trauma como diagnóstico da experiência migratória - diferentemente da concepção trabalhada por nós anteriormente - produz em termos de discurso sobre o sujeito migrante? Guiados por essas perguntas, trataremos de desenvolver algumas reflexões.

De um lado, pensamos na dimensão traumática vivenciada pelos sujeitos como modalidades de sofrimento face aos acontecimentos-extremos aos quais foram submetidos, eventos disruptivos de exclusão dos sujeitos do laço. De outro, assistimos à proliferação da categoria de trauma como modos de patologização das vivências migratórias de populações tidas como indesejáveis. Diante dessas duas perspectivas, pensamos nas formas de favorecer a restituição da dimensão coletiva de experiência no contexto das intervenções clínicas com essa população. Se a própria vivência traumática produz estilhaçamento subjetivo e exclusão do laço, entendemos que os discursos hegemônicos de alastramento da categoria de trauma nos contextos humanitários como patologia vêm sobrepor a mesma violência de exclusão na medida em que despolitizam o acontecimento em sua dimensão coletiva e esvaziam a própria noção de experiência. Veremos com mais atenção esse ponto. 
Como tratamos no primeiro capítulo, as políticas imperialistas pós-coloniais, assim como as medidas e intervenções tanto de fronteiras quanto de externalização das fronteiras e as ausências de mecanismos de salvamento e acolhimento produzem sistematicamente uma degradação nas condições de vida e nas possibilidades de deslocamento das populações mais pobres. Sabemos que as experiências de precariedade e violência produzem sofrimento psíquico e têm desdobramentos diretos na subjetividade. O que nos interessa nesse momento, no entanto, é pensar nos desdobramentos de um alastramento da percepção do deslocamento como produtor de perda, de falta, e consequentemente na produção da figura do refugiado ou migrante como vítima através, também, dos discursos de patologização.

Um exemplo ilustrativo dos discursos que compreendem as vivências migratórias sempre em sua dimensão de falta - através de noções como dificuldade de integração, dificuldades linguísticas, desenraizamento, processos de aculturação - é a recente categoria proposta pelo psiquiatra espanhol Joseba Achotegui (2012) de "Síndrome do imigrante com estresse crônico e múltiplo", conhecida como "Síndrome de Ulisses". Através de uma sintomatologia que abarca elementos como sentimento de solidão, tristeza, ambiguidades no processo migratório, culpa, reações de insônia, estresse, dores de cabeça, fadiga, entre outros, o psiquiatra Achotegui (2012) sugere que a migração é um fator de risco, sobretudo em vista dos fluxos atuais de deslocamento, o que poderia vir a ocasionar uma situação de saúde pública nos países de acolhimento.

Perda é o elemento mais central nessa categorização sobre o sofrimento do sujeito migrante, e segundo Achotegui (2012), são sete os fatores de risco da migração: a perda da língua, da cultura, da terra, do círculo social e familiar, dos grupos de pertencimento e os riscos por sua integridade física. Em suma, compreender a vivência migratória a partir da proposição da Síndrome de Ulisses compreende o sujeito migrante como uma figura de extrema vulnerabilidade, quase como “alguém muito vulnerável que irá desenvolver problemas psicológicos que deverão ser medicalizados" (KNOBLOCH, 2015, p.172). Avaliação de risco patológico profícuo às mesmas dinâmicas totalizadoras que visam interditar a circulação de populações pobres pelo mundo. Isto é, patologização e criminalização como dois grandes discursos de segregação do laço.

A proliferação da categoria de trauma nos últimos trinta anos fez com que essa denominação passasse não só a compor o léxico do senso comum saindo do campo estritamente médico, como também fundou uma nova linguagem do próprio acontecimento. 
Os antropólogos e psiquiatras franceses Didier Fassin e Richard Rechtman (2007), na obra "L'empire du traumatisme: enquête sur la condition de victime", dedicaram-se a investigar profundamente essa problemática através de duas perspectivas: a de reconstituir uma genealogia do trauma, isto é investigar seus aspectos morais; e a de realizar uma etnografia, analisando os impactos da utilização dessa categoria em alguns campos específicos, tais como a dos refugiados.

Nas últimas décadas, em paralelo à concepção psicanalítica sobre o traumático, vemos uma diversidade de tecnologias terapêuticas, sobretudo inscritas no campo da psicologia comportamental e cognitivista que utilizam amplamente essa categoria para propor intervenções. No campo humanitário internacional, na ocasião de uma catástrofe, já é possível se estimar um montante de pessoas traumatizadas, e consequentemente ofertar os recursos de intervenção. Nesse sentido, trataremos de problematizar os desdobramentos do emprego atual da categoria de trauma no que se refere aos contextos de migração.

Com os Fassin e Rechtman (2007), partimos de um questionamento inicial:

A intervenção de psicólogos e psiquiatras no teatro das guerras e catástrofes, das violências extremas ou ordinárias tornou-se coisa normal aos olhos de nossos contemporâneos. Ninguém se espanta que esses profissionais de saúde mental saiam de suas instituições de cuidado e de seus consultórios para se colocarem diante dos 'feridos psíquicos'. Admitimos com a mesma facilidade que eventos trágicos e dolorosos, individuais ou coletivos, imprimem no espirito marcas que, por analogia com as que são produzidas no corpo, são também pensadas como 'cicatrizes'(FASSIN \& RECHTMAN, 2007, p.245).

Categoria amplamente utilizada a partir dos anos 1980, trauma passou a significar uma nova linguagem do acontecimento, fato que levou Fassin e Retchman (2007) a considerarem o traumatismo como uma chave de interpretação do mundo contemporâneo. Assim, os autores propõem uma leitura crítica do traumatismo que recusa sua naturalização ou emprego indiscriminado.

A disseminação da categoria de trauma na contemporaneidade diz de uma reconfiguração da economia moral de nosso tempo, na medida em que o sofrimento dos sujeitos considerados traumatizados só passou a ter legitimidade a partir de determinado momento histórico. É, portanto, de dois tempos que parte a análise dos autores, de um primeiro tempo do traumático como elemento de suspeição, a um segundo momento de produção de verdade. Nesse sentido, é possível compreender uma mudança substancial no 
regime de veridição em torno da noção de trauma. Isto é, trata-se de compreender como o falso se tornou verdadeiro, pois um dos desdobramentos desse deslocamento foi o de instituir, através dessa compreensão do traumático, uma nova condição de vítima. Trauma é assim compreendido como uma produção social concomitante à instituição da figura da vítima na contemporaneidade.

Sabemos da geração de psicanalistas que combateram ou atuaram nos fronts desde a Primeira Guerra Mundial. Abraham, Ferenczi, Simmel, Tausk são pioneiros nos primeiros estudos psicanalíticos sobre o trauma. É também influenciado por esses discípulos que Freud desenvolve seus estudos sobre a neurose de guerra e o traumático. No entanto, esse ainda era o momento em que o trauma era tomado sob o regime da suspeição. Diferentemente do que vinha sendo pensado pela psicanálise na época, a medicina psiquiátrica durante a Primeira Guerra Mundial caracterizou-se predominantemente pelos métodos de brutalização terapêutica, de eletrochoques e outros procedimentos semelhantes aos de tortura, todos a cargo dos serviços de saúde dos exércitos: tratava-se de implementar tecnologias que fizessem os soldados voltarem o mais rapidamente ao front. A lógica era a da suspeita de que por detrás da complexa sintomatologia apresentada pelo soldado houvesse uma simulação de adoecimento para escapar do front de batalha. Por covardia ou falta de patriotismo, o soldado de guerra traumatizado era uma vítima ilegítima.

No entanto, um novo regime de veridição passa a operar em detrimento do anterior, e onde havia suspeita, passa a haver verdade sobre um acontecimento. Assim, ocorre a mudança de uma cultura que suspeitava da autenticidade do sofrimento, para um segundo tempo em que, legitimado como acontecimento traumático, passou a ser suficiente para conferir verdade ao sofrimento das vítimas de uma situação extrema.

Foi justamente em 1980 que o TEPT (Transtorno de Estresse Pós-traumático) foi descrito pela primeira vez na terceira edição do Manual diagnóstico e estatístico dos transtornos mentais (DSM-III). A partir de um grupo de trabalho de pesquisadores que se debruçavam sobre o sofrimento de sobreviventes da guerra do Vietnam, se estabeleceu a primeira sintomatologia daquilo que passou a ser considerado como um diagnóstico psiquiátrico fora do comum: trava-se de manifestações normais diante de um evento anormal. Uma nova era do traumatismo se inicia, não se trata mais de buscar as origens de um trauma inaugural do sujeito, a etiologia da patologia passa a ser o próprio acontecimento. 
O conjunto dos sintomas do transtorno de estresse pós-traumático é caracterizado sobretudo por lembranças invasoras que fazem reviver o acontecimento, tais como pesadelos, sonhos diurnos ou flashbacks; inibição significativa com o mundo externo ou situações que se refiram ao evento; assim como sintomas de hiper-vigilância. Nos manuais seguintes, o diagnóstico se complexifica e essa compreensão sobre o traumático é largamente difundida.

Podemos nos perguntar sobre algumas consequências dessa nova concepção sobre o trauma instituído pela psiquiatria. Por um lado, com a mudança no regime de veridição, aquilo que pairava como suspeição passa ser levado em conta, isto é, agora, vítimas de determinado adoecimento psíquico podem ser tratadas (clinicamente) ou reparadas (moralmente ou financeiramente) sem que se suspeite de sua veracidade, o sofrimento passa a ser legítimo. No entanto, é possível pensar que essa nova concepção - ao compreender o trauma como um adoecimento normal, previsível e esperado diante de um acontecimento que é extraordinário - produz consequências subjetivas importantes. Vamos a algumas delas.

O primeiro ponto é o de pensar que traumático é o próprio acontecimento real e não a vivência subjetiva diante do acontecimento, concepção que toma o trauma a partir de uma homogeneidade. Assim, são os próprios sintomas do sujeito que deixam de ser interrogados. Se pensarmos com Freud nos sintomas como formação de compromisso entre duas instâncias, a intervenção clínica se dá justamente através da escuta da singularidade dos sintomas de cada sujeito em relação a seu adoecimento. Produto do recalque, para Freud, o sintoma responde tanto à satisfação de um desejo inconsciente quanto à instância de defesa. Trata-se, portanto, de uma "formação de compromisso que amalgama na sua rede a defesa (o agente do recalque) e o recalcado" (OCARIZ, 1999). Isto é, enquanto sintomas normais diante de um evento anormal, não é o adoecimento que é despatologizado, mas o sujeito que deixa de ser tomado estritamente em sua singularidade, na malha em que teceu sua própria problemática. Desse modo, não se trata mais de colocar em relevo os benefícios secundários da doença, como pensou Freud.

Por ganhos secundários da doença, Freud não pensou o adoecimento no regime da suspeição, o sofrimento é legitimo e os sintomas são autênticos, mas um passo a mais também é dado pela psicanálise: trata-se de escutar, na constituição subjetiva de cada sujeito o modo próprio de adoecer diante de alguma situação. A nova concepção sobre o traumático alastrada pelo diagnóstico psiquiátrico produz por consequência uma nova figura de vítima. Sujeito passivo da situação a qual esteve exposto, não se trata mais de se abordar as formas de 
enunciação de seu sofrimento. Ou ainda, a experiência é esvaziada e o acontecimento é despolitizado de sua dimensão coletiva. Assim, segundo Fassin e Rechtman:

\begin{abstract}
A produção social do trauma e o reconhecimento moral das vítimas tiveram um custo. Não somente todas e todos não tiveram acesso a esse status e aos benefícios eventuais que daí poderiam extrair, mas mesmo aqueles que eram suscetíveis de se reclamar como tais perderam uma parte de sua história e muito de sua capacidade de contá-la (p.237).
\end{abstract}

Tomando a citação dos autores, podemos pensar que a nova produção social sobre o traumático e o consequente reconhecimento moral das vítimas teve primordialmente dois efeitos: 1) na economia moral sobre o traumático, nem todo mundo acede ao mesmo estatuto de vítima - podemos pensar aqui na diferença entre aqueles que são ou não considerados vítimas em determinada situação, ou ainda, como dizem os autores, sobre a produção de um reconhecimento seletivo; 2) enquanto vítimas, muito da possibilidade de enunciar a própria experiência é apagada em detrimento da categorização, ou da patologização. Tratemos de compreender melhor o segundo ponto.

Se, por um lado, a categorização psiquiátrica do traumático produziu reconhecimento do sofrimento de pessoas que vivenciaram situações extremas e que anteriormente poderiam ficar à margem de qualquer cuidado; por outro, algo da possibilidade de contar e significar a própria história - ou experiência - pelos sujeitos parece ter sido apagada. Fenômeno que revela duplamente aquilo que uma categorização pode fazer aparecer e suprimir em um só movimento. Se a instituição e alastramento dessa categoria psiquiátrica produz a figura da vítima, tratemos de pensar o quê, no movimento de nomeação das vítimas, deixa de ser enunciado.

Antes de percorrer algumas pistas, podemos ainda reformular essa questão, utilizando de um exemplo largamente trabalhado por Fassin e Rechtman (2007) nessa mesma obra: a emissão de certificados psiquiátricos para solicitantes de refúgio na França. No contexto de políticas cada vez mais restritivas e de taxas de reconhecimento de refúgio muito baixas, o certificado médico atestando um transtorno psiquiátrico passa a ser um instrumento a mais de reivindicação de um direito diante das instâncias de elegibilidade. Segundo os autores: "quando o certificado médico que atesta o TEPT tem mais crédito que a palavra do solicitante, que concepção de sujeito e de direito está em jogo?” (FASSIN \& RECHTMAN, 2007, p.20). Isto é, qual o lugar da palavra e da narrativa do migrante sobre sua própria 
experiência? Quais as possibilidades de um refugiado poder enunciar sua própria história? Ou ainda, na medida em que uma categoria revela uma condição, o que ela também apaga?

O alastramento da categoria de trauma coincide com as lógicas hegemônicas de controle e restrição de circulação de determinadas populações em direção aos países mais ricos. Nesse sentido, as modalidades de gestão do trauma estão em consonância com as múltiplas tecnologias terapêuticas em questão. Os exemplos são vários: desfusão cognitiva que visa instaurar uma distancia psicológica entre pensamentos e sentimentos, dessensibilizando a experiência; flexibilidade psicológica; terapias de aceitação e compromisso, tratamentos medicamentosos, tecnologias de eliminação da memória e desafetação. A instauração de uma nova linguagem do acontecimento enquanto trauma reverbera no apagamento da dimensão política da experiência migratória. No alastramento dessa categoria e na patologização da experiência é a dimensão política do sofrimento que parece ter sido extorquida nesse mesmo movimento.

No interior de cada nova intervenção clínica no campo da saúde mental, a realidade psíquica mais singular também é confrontada pela reprodução social atual. Nos contextos de hiper-medicalização psiquiátrica, patologizações das experiências migratórias e técnicas psicoterapêuticas que têm como fim o silenciamento dos sintomas, é a patologização da diferença (KNOBLOCH, 2015) nas experiências migratórias que passa a operar como forma de reconhecimento, e dessa forma, a linguagem psiquiátrica passa a assumir o lugar do malentendido que o encontro com o diferente tende a provocar (Ibid). Compreendemos esse movimento como dinâmicas de despolitização do sofrimento pelas mesmas malhas de dominação (ROSA, 2012b) que enredam os sujeitos migrantes em sua circulação.

Tendo em vista esse debate, não se trata, no entanto, de renunciar ao uso do conceito de trauma. O que propomos, simplesmente, é situar a compreensão do traumático em relação aos discursos hegemônicos no campo das migrações. Em relação ao alastramento do conceito e seus efeitos patologizantes sobre o sujeito e de despolitização do acontecimento, pensamos nos servir do conceito de trauma a partir da compreensão dos efeitos de sofrimento do sujeito em função de seu contexto, e, nessa perspectiva, como vimos, entendemos que diante do acontecimento-extremo de violência, traumático se refere às modalidades de angústia e sofrimento do sujeito.

Sendo assim, frente aos discursos patologizantes inscritos em uma economia moral que produz segregação, gostaríamos de propor uma outra reflexão sobre a noção da 
experiência migratória atualmente. Seguindo também o fio daquilo que insiste como vida diante da ameaça constante de morte, vamos seguir pensando nessa questão a partir da perspectiva pulsional e, a partir daquilo que Nathalie Zaltzman (2011) nomeia como pulsão anarquista, pensar os modos de sobrevivências e as zonas de resistência diante da morte. Para seguir na discussão das noções de trauma e experiência, abordaremos a partir da questão pulsional as saídas políticas do sujeito para a restituição de laço.

\subsection{A vida que insiste: reflexões sobre a sobrevivência e as zonas de resistência}

Quando comecei a trabalhar com refugiados e ouvir suas narrativas, as categorias de migrações forçadas e migrações desejadas passaram a ressoar seu caráter, tanto arbitrário quanto revelador, de um processo bastante singular dos deslocamentos contemporâneos e, nesse sentido, uma questão passou a insistir: o que move as pessoas a se deslocarem apesar das mais profundas destruições? Trataremos de abordar essa questão sob alguns aspectos.

Sobre as arbitrariedades das categorias, duas me parecem ser as razões preponderantes: 1) porque, como vimos, pretendem separar as chamadas migrações motivadas por fatores econômicos das migrações que justificam a solicitação de refúgio de acordo com a Convenção de Genebra - separação mais do que tudo moral, entre necessidade, urgência e legitimidade de instalação em função de fatores determinados; e, 2) porque reduzem dicotomicamente a experiência de deslocamento entre, de um lado, só a um anseio de migrar e, de outro, a um caráter unicamente forçado, quase que sem agência do sujeito.

Ambas são categorias do direito internacional, mas que nos interpelam diretamente, uma vez que vêm nomear a experiência de deslocamento dos sujeitos. Deixar de considerar a dimensão forçosa de deslocamentos motivados por razões econômicas e considerá-las somente como desejadas é revelador de uma lógica que ignora a precariedade social engendrada pelas lógicas do capital ao redor do mundo; na mesma medida em que deixar de considerar a dimensão desejante dos deslocamentos motivados por razões de perseguições e destruições ignora toda a potência de resistência dos sujeitos confrontados com condições extremas, delegando a eles somente uma posição quase cristalizada de vítima.

Diante de tantos relatos de horror, perda, destruição e urgência das diversas formas de migração, a dimensão da sobrevivência parece ser elemento preponderante, mas sobretudo em seu caráter de potência da insistência de vida. Morrer sempre me pareceu ser uma escolha 
possível, e é nesse sentido que essa questão passou a ressoar: como depois de tantas perdas e destruições a eles infligidas, alguns sujeitos não só permanecem vivos, como têm a força de se deslocar, e uma vez em um novo país, mesmo que atravessados por um profundo sofrimento, logram reconstruir suas vidas e refazer laço? Reconstrução marcada pelo trauma do acontecimento, mas que adquire dimensão de resistência e luta face às condições extremadas da vida. De que ordem então se trata essa insistência de vida que segue pulsando à revelia das dinâmicas mais totalizadoras?

Do ponto de vista pulsional, podemos relançar a pergunta: relação particular entre Eros e Thanatos (DAVOUDIAN, 2014), em que conjunção de pulsões poderíamos compreender o fenômeno de permanecer vivo diante de situações de destruição alastradas? Ou ainda, como abordar uma migração como sendo forçada se sua maior condição foi a de se deslocar? Tendo como disparador esse conjunto de perguntas, a simples divisão entre migrações forçadas e desejadas é reveladora de uma determinada economia moral e profundamente redutora de um processo mais complexo de insistência da vida.

Como vimos anteriormente, as trajetórias dos deslocamentos atuais muitas vezes são marcadas por longas e árduas jornadas nas condições mais extremas. O périplo perseguido por milhares de pessoas diariamente em uma geografia mundial cada vez mais marcada por fronteiras muradas faz com que a insistência pela vida esteja permanentemente confrontada pela ameaça de morte. Loné foi uma jovem eritréia que conheci nas ruas de Paris dois dias após sua chegada na capital francesa. Loné era muito jovem mas tinha no seu semblante o cansaço e as marcas dos meses de deslocamento. De confissão cristã, passou a ser perseguida na Eritréia, de onde decidiu emigrar junto a um grupo pequeno de mulheres. Lomé me conta de sua jornada, muitos meses, muitos acontecimentos, muito medo e muito risco empreendido, sempre a vida por um fio, mas fio que permanece insistindo. Conta-me da travessia do deserto do Sahara, de todos os mortos pelo caminho, os meses em cativeiro escravizada na Líbia: “disso não posso dizer nada, não tenho palavras para falar do que me aconteceu, nunca nenhum ser humano deveria saber o que se passa na Líbia”, a travessia pelo Mar Mediterrâneo, a chegada à Itália, as fronteiras europeias terrestres. Medo, fome, desamparo, frio, violência policial, hostilização nas cidades, esperas incessantes, muita suspensão. Mas Lomé insiste e chega a Paris ainda sem saber muito o que esperar ou o que buscar. Procurava naquele dia garantir a sobrevivência em um dia de inverno, ter um lugar onde dormir e auxiliar suas companheiras de viagem, algumas doentes e com dores de tanto 
andar. Penso ininterruptamente: o que faz tantos sujeitos, como Lomé, empreenderem percursos como esses à revelia de tudo que pretender barrá-los ?

Se pulsão de vida se refere a todo movimento humano que faz laço, constrói e cria unidade, e, em outra via, pulsão de morte de tudo o que separa, desconecta e destrói unidade, como pensar a sobrevivência diante de condições extremas? Nesse mesmo sentido, a psicanalista francesa Nathalie Zaltzman (1974) formulou uma questão semelhante:

As situações limites existem. Alguns seres humanos as afrontam, as vivem ou as transpõem, enquanto outros a elas sucumbem, desagreagam-se na psicose, na apatia, submissos à fatalidade de seu extermínio. Como resistem os que as vivem? A partir de que fonte de energia? (p.64).

É dessa interrogação que ela propõe o conceito de pulsão anarquista, a pulsão revolucionária, essa mesma que insiste com vida diante da iminência da morte. Conceito profícuo para pensarmos na dinâmica pulsional própria dos contextos de migração em situações limite. Energia da pulsão de morte, a pulsão anarquista é aquela que sustenta transformação através do desligamento, que mantém a vida nas condições mais extremas, que proporciona manutenção de vida, mas também mudança e deslocamento quando morte representa ligação.

Isto é, em face da perda de todos os mais queridos, morrer não seria a continuidade das forças de ligação de Eros? Morrer diante da destruição massiva de todos os seus pode ser, nesse sentido, pulsão de vida - em seu sentido de ligamento e unidade. Permanecer vivo mas não só, pois migrar implica na renovação permanente de insistir com o projeto de deslocamento - é sustentar o desligamento de forma constante a tudo aquilo que outrora representava unidade, e aqui podemos pensar no deslocamento geográfico, na língua, cultura, e outros referenciais.

Ainda segundo Nathalie Zaltzman, sobre a pulsão anarquista:

Numa relação de forças sem saída, só uma resistência nascida das próprias fontes pulsionais de morte pode afrontar a ameaça de perigo mortal. Chamo este fluxo da pulsão de morte mais individualista, mais libertário, de pulsão anarquista. A pulsão anarquista guarda uma condição fundamental da manutenção em vida do ser humano: a manutenção para ele da possibilidade de uma escolha, mesmo quando a experiência-limite anula ou parece anular toda escolha possível (p.64). 
É da investigação sobre a sobrevivência em estados-limite, que Zaltzman pretende mostrar uma história da pulsão de morte que não seja somente de agressividade ou de finalidade mortífera, mas de vicissitudes úteis à vida. Isto é, trata-se de um trabalho psíquico de Thanatos sem efeitos mortíferos, pulsão de morte que cria condições revolucionárias de mais vida, de outra vida. Condições para a transformação de uma vida em outra vida. Que outro movimento representa esse deslocamento tão bem senão as migrações? No deslocamento, não só a possibilidade de salvar a própria vida mas também a de se fazer outro em outro lugar.

A pulsão anarquista, energia da pulsão de morte, é revolucionária justamente por seu caráter de resistência à aniquilação. Sobreviventes que migram hoje, resistem com sua insistência de vida igualmente a todas as lógicas hegemônicas que visam destruir, anular e aniquilar seus corpos, suas narrativas e seus modos de existência. Desse modo, o movimento pulsional é revolucionário porque "surge quando toda forma possível de vida desmorona, ele extrai sua força da pulsão de morte e a remete contra ela e sua destruição." (ZALTZMAN. 1974, p.66). Assim, só a energia dissociativa de Thanatos é capaz de produzir o ímpeto libertário de permanecer vivo.

Trata-se, portanto, da insistência da vida em zonas de resistência do sujeito. Zonas de resistência diante dos mecanismos destrutivos de um poder que executa o deixar morrer fazendo morrer nas fronteiras, a partir do próprio mortífero pulsional. Isto é, perante da maquinaria mortífera de aniquilação das populações-resto, da necropolítica (MBEMBE, 2018) a resistência de permanecer vivo provém de fonte de Thanatos. Insistência e resistência, dois significantes possíveis para pensarmos em um dos destinos pulsionais de sujeitos diante de sua própria aniquilação. Se, de um lado, as dinâmicas totalizadoras não cessam de reduzir os sujeitos a seus corpos, é com seus corpos que, implacavelmente, eles resistem e insistem com suas presenças. Trata-se, portanto, de uma pulsão política.

Sabemos que a fonte da pulsão anarquista é de morte porque, como nos diz Zaltzman: "cada vez que Thanatos ocupa o primeiro plano na cena psíquica, o objeto libidinal se impõe como um objeto de necessidade" (p.47). Assim, trata-se da necessidade de permanecer vivo e insistir em chegar onde querem chegar à revelia de todas as dinâmicas mortíferas de aniquilar esses mesmos corpos. Zaltzman, com a pulsão revolucionária, se propõe a pensar no destino e nas possibilidades de travessia da experiência-limite para o sujeito. Ao apropriar-se da morte a serviço da vida, a pulsão anarquista obtém energia de luta nas zonas de resistência do 
sujeito. Assim, migrações em contextos extremados da vida são tanto forçadas quanto desejadas: uma relação dialética que permanentemente relança o sujeito em movimento.

Isto é, muito mais do que optar por uma categoria ou por outra, ou mesmo de propor uma nova categoria, pensamos na dinâmica dos deslocamentos contemporâneos como a relação permanente entre a dimensão forçosa e desejada. No trânsito, o sujeito pode se fazer valer dos dois extremos, ou ainda, fazer valer a dimensão do deslocamento lançando mão da significação das duas categorias. Compreendida enquanto dimensão forçosa, os sujeitos fazem da categorização também o reconhecimento de uma condição real vivida e da possibilidade de fazer valer um direito: o do refúgio. Em sua dimensão desejante, também pode-se fazer significação, movimento e reinvenção de vida em terra de exílio. Isto é, a chegada em novo lugar só é possível na medida em que algo singular, mas também coletivo, for mantido.

Com o caso de Levy, vimos em seu percurso duas modalidades de migração, seu deslocamento interno de Kinshasa para o leste do Congo em busca de trabalho e melhores condições de salário para sustentar sua família, e seu deslocamento para o Brasil, em fuga, para garantir a sobrevivência. A partir dos desdobramentos do caso, vimos também as possibilidades de ressignificar a experiência de exílio a partir dos modos desejantes de existência em um novo contexto. Nesse sentido, é em uma relação dialética entre a dimensão forçada e desejada que podemos compreender os movimentos, também pulsionais, de migração pelo globo tanto em busca de sobrevivência como de resistência aos mecanismos hegemônicos de dominação e aniquilação das populações mais pobres.

Também com o caso de Cecil, desenvolvemos algumas das direções clínicas diante do sofrimento extremo de sujeitos que se confrontaram com a ruptura do laço para pensar em seguida a noção de trauma como modalidade de sofrimento em decorrência da catástrofe. Desse modo, pensamos, a partir da noção de imediatez, nos modos de intervenção que recomponham a dimensão de experiência do acontecimento no instante do front. 


\section{Capítulo 4}

\section{Nas fronteiras entre línguas, culturas e papéis: o analista-coiote}

Ser dois para mim é a única unidade concebivel

(Romain Gary)

Diante das múltiplas fronteiras entre línguas, culturas e papéis das burocracias de regulamentação e reconhecimento nas trajetórias de deslocamento, pensaremos nas possibilidades de intervenção clínica. Como analista-coiote compreendemos um modo de posicionamento diante das cisões operadas no deslocamento. Posicionamento que promove a passagem e o atravessamento visando a própria circulação e instalação dos sujeitos na possibilidade de tanto transitar quanto em habitar o duplo, trataremos através de algumas vinhetas clínicas algumas dessas problemáticas.

Passeur é o termo que Jacques Hassoun (1994) se utiliza para nomear a figura de um agente que, pelo encontro, proporciona o deslocamento necessário para que algum outro se aproprie de sua própria cultura, história ou de sua transmissão, ou, em outras palavras, para que haja a passagem entre o indizível e sua nomeação. Em clara referência à ideia do passe lacaniano, o passeur não é só a figura que autoriza o sujeito a se haver com seu próprio legado, mas faz também função de ponte e passagem de uma geração à outra, na lógica da transmissão. Passador seria uma tradução possível para o português, no entanto, passeur, em francês, é também o nome dado ao que, em português, chamamos de coiote ou atravessador.

Coiote é nome asteca dado a um animal da família dos lobos que vive tanto na região do deserto como na zona tropical entre a América Central e a América do Norte. Coiote é também o nome dado ao agente de migração ilegal, figura fortemente criminalizada pelas leis migratórias internacionais, trata-se de pessoas que auxiliam o cruzamento clandestino das fronteiras entre países. Coiotes, smuglers, traficantes de pessoas, são para as leis das migrações internacionais agentes criminosos que burlam os dispositivos de fronteira 
enriquecendo através da travessia ilegal. No entanto, coiotes, em alguns contextos, também são pessoas que presenciando a situação criminosa da política dos muros, auxiliam migrantes a se deslocarem, fazendo valer o direito humano básico de poder migrar e se instalar.

Reconhecemos que diversas pessoas, grupos organizados e redes mais complexas enriquecem às custas de um sistema migratório que prolifera muros e barreiras entre os países, e assim, submetem pessoas a condições de exploração e precariedade. Conhecemos igualmente inúmeras histórias de situações de violência vivenciadas por pessoas em seus percursos de travessia e perpetradas pelos agentes de deslocamento. Redes criminosas internacionais existem, porém, a retórica da criminalização do chamado tráfico de pessoas, tem sido igualmente problematizada por pesquisadores que defendem tratar-se de uma falsa questão migratória. Segundo Guilher Mansur, em entrevista (FARHAT, 2016), no discurso de criminalização do chamado tráfico de pessoas, encontram-se também os mecanismos de governabilidade, gestão e controle de populações para os países mais ricos. Isto é, a proliferação de dispositivos de controle dos agentes atravessadores nas fronteiras ofusca as reais motivações que levam as pessoas a se deslocarem e criminaliza uma figura menor em todo o processo de controle do fluxo de pessoas. Se fizermos um paralelo a título ilustrativo, poderíamos pensar que a criminalização dos coiotes é semelhante à realizada no Brasil aos chamados "aviõezinhos" nas favelas ou do vendedor de droga mais precarizado em detrimento dos grande produtores e traficantes de droga no país. Trata-se da ponta do iceberg de um fenômeno muito maior, fenômeno esse, no caso das migrações, fruto das políticas de muro ${ }^{59}$ e da produção social do deslocamento.

Em paralelo a isso, na Europa, vimos até recentemente iniciativas como a do pequeno agricultor Cedric Herrou, sido criminalizadas como delito de solidariedade ${ }^{60}$ - forma como foram conhecidas algumas leis que criminalizavam pessoas que auxiliam o trânsito ou acolhem migrantes nos países Europeus. Até pouco tempo, na França, pessoas que ajudavam migrantes a atravessar fronteiras podiam pegar até cinco anos de prisão e pagar trinta mil euros de multa. Cédric Herrou era um pequeno agricultor instalado na região do Vallée de la Roya, na França, fronteira com a Itália, que, de sua janela, começou a ver o périplo de

\footnotetext{
${ }^{59}$ Tema abordado no item 1.2 da tese.

${ }^{60}$ Delito de solidariedade não existia enquanto tal na lei, tratava-se apenas da forma como eram chamadas as medidas de criminalização de pessoas que ajudam migrantes a cruzarem fronteiras ou hes acolhendo em suas casas. Porém, em julho de 2018, o Conselho Constitucional francês anulou a medida conhecida como 'delito de solidariedade' descriminalizando esses atos em detrimento do 'Princípio de fraternidade', grande vitória obtida por Cédric Herrou.
} 
centenas de pessoas que diariamente tentavam cruzar a fronteira e sofriam as mais diversas violências policiais e impossibilidades de deslocamento. Tendo livre acesso à fronteira, com seu pequeno furgão, Herrou começou a auxiliar migrantes na travessia, e, sem cobrar nada por isso, também passou a hospedar pessoas em sua casa e auxiliar outras de diferentes formas. Quando descoberto, Cedric foi condenado a pagar uma multa de 3 mil euros, em seguida foi preso e por algum tempo não pôde deixar o território nacional. Preso em seu próprio país por ajudar outros a saírem dos deles, exemplos como esse proliferam em toda Europa. Recentemente, o Conselho Constitucional francês, em uma grande vitória para a população migrante, pôde reconhecer gestos como o de Herrou, como "atos de fraternidade", descriminalizando, sob algumas condições, ações como essas.

Passador para Hassoun (1994) é a figura que, tanta vezes clandestinamente, por contrabando, é o que promove o encontro do sujeito com seu próprio legado interrompido e, nesse sentido, o autor se pergunta: "não seria o estrangeiro um passador de culturas que vem dar sentido ao insensato de uma tradição morta e de uma banalização impossível?” (p.64).

Instalados em uma posição estrangeira, seja pela escuta do inconsciente, ou por ocuparmos um lugar estrangeiro pela língua e pela cultura, nós analistas não seríamos, portanto, possíveis agentes do atravessamento entre as fronteiras do deslocamento entre línguas, culturas e experiências? Falamos previamente (capt. 3) da função porto da presença do analista, sublinhamos a importância da ancoragem como elemento para desembarcar em terra de exílio; agora abordaremos a perspectiva desde um outro lugar possível: o do analistacoiote entre línguas, culturas e fronteiras, que muitas vezes também são jurídico-institucionais (veremos no 4.4).

Aqui, salientamos outro caráter da figura do coiote, não o das redes internacionais de enriquecimento às custas da precarização humana, mas o da intervenção que, pelo encontro, proporcione $\mathrm{o}$ atravessamento de fronteiras interditadas seja pelas barreiras dos nacionalismos, dos interesses do capital, da necropolítica, mas também das transmissões interrompidas, das experiências limites próprias do traumático. Nesse sentido, trata-se de um engajamento, de uma tomada de posição diante das políticas de muro, trata-se do caráter clandestino (HASSOUN, 1994) do analítico ${ }^{61}$.

\footnotetext{
${ }^{61}$ Como não lembrar aqui da frase atribuída a Freud (1909), em outro deslocamento, na ocasião da viagem de navio para os EUA: "mal sabem eles que estamos levando a peste".
} 
Nesse capítulo iremos trabalhar a partir de alguns casos e fragmentos clínicos a questão da língua nos atendimentos, os elementos culturais, as injunções institucionais e seus desdobramentos subjetivos para pensarmos nas intervenções que proporcionem precisamente o atravessamento de fronteiras e pertencimentos.

Tomamos a questão das diferentes línguas e culturas presentes nos atendimentos não como especificidade na clínica, mas como recursos do sujeito, no sentido das possibilidades de remontagem de si em contexto de desterritorialização. Assim, é justamente através dos atravessamentos entre línguas e entre culturas que pensamos a direção de uma intervenção clínica. Novamente, estrangeiro é o lugar do analista, esse que pelo encontro, cria condições de passagem para a possibilidade de habitar o duplo como lugar de enunciação.

\subsection{Entre língua materna e a língua estrangeira: reflexões sobre a língua do analista}

Durante um atendimento com uma menina boliviana, que nos primeiros meses vinha sendo feito em português, decido, em dado momento, lhe falar em castelhano, língua que habito com proximidade. Carla então deita no meu colo e começa a mexer no meu cabelo (penso no bebê no colo da mãe tocando em seus cabelos). Castelhano é para Carla, de certa maneira, uma língua esquecida. Esquecida? Certamente recalcada. Pois ao ouvi-la, de pronto, outros registros são acessados. No curso desse fragmento clínico que narro, algo nos interpela. Nosso acento não é o mesmo. "Por que você fala assim?", ela me pergunta. Pela sonoridade e entonação distinta do meu sotaque, de certa forma, eu apareço, mas também e, sobretudo, ela aparece. Carla ri um pouco, pergunta coisas sobre mim, tenta me imitar, mas o fato é que me imitando, me ouvindo, pode também perceber as particularidades de seu próprio acento. Pode perceber novamente sua própria língua que emerge pela familiaridade estrangeira de uma outra/mesma língua. Castelhano é língua materna, a língua que falava antes de perder sua mãe, na Bolívia, e migrar com o pai e três irmãs para o Brasil. Junto ao país, a família deixou também o castelhano pelo português.

"Para de falar desse jeito, fala comigo em português", me pediu, certa vez, sua irmã mais nova. Ou também, em outros atendimentos: "Você fala francês. Então podemos conversar. Você pode me entender". No campo das migrações, como analistas, somos permanentemente interpelados a circular entre algumas línguas, línguas que não nos são 
necessariamente maternas, línguas com as quais temos as mais distintas transferências, línguas que habitamos com mais ou menos fluência. O deslocamento permanente entre línguas é, portanto, condição de trabalho, para analista e analisando. Nesse sentido, muitas questões se colocam. Vamos a algumas que giram em torno da possibilidade de colocar em relação, a partir do atravessamento, a língua materna com as línguas estrangeiras.

Utilizar-se de uma epígrafe para iniciar um texto, para Jacques Hassoun (1979), pode ser um recurso que revela tanto a presença de uma autoridade inspiradora, como também limitante: "Situar um escrito sob a autoridade de um outro, marca a escolha deliberada de apenas se autorizar a avançar e a defender uma ideia quando cercada de algumas garantias de respeitabilidade" (p.34). Autoridade inspiradora e limitante que nos precede. De que outra ordem seria a língua materna senão essa? Alguns veem aí a língua dos afetos, dos prazeres, de tudo aquilo que rodeia para expressar a própria vida. Modelo da inscrição simbólica no corpo, a lei é introduzida através da língua materna. Língua que deixa traços, marcas, pegadas, vestígios quase anatômicos, é a inscrição no próprio corpo, ou mesmo, a própria pele, diria Freud sobre essa mesma língua.

É sabido que língua materna para os gregos foi durante muito tempo não uma língua, mas a única língua. Não por acaso a palavra para designá-la era logos, razão. A todos aqueles que não falavam grego, apenas uma designação: bárbaros, onomatopeia para dizer, em grego, "blablabla", aquilo que não se entende. Foi na guerra contra os persas, na Grécia antiga, que então essa nova designação foi capaz de dividir a população mundial em dois: gregos e bárbaros; nós e os outros. E a maneira mais eficaz para distinguir, perceber e identificar a presença do estrangeiro era através do manejo da língua grega, pois bárbaros eram aqueles que não falavam grego, ou que se falavam, falavam mal, com o que chamamos em português de sotaque. É interessante ter em conta a racionalidade presente nessa lógica de distinção. Todorov (2008) nos lembra sobre a coincidência de sentidos da palavra logos em grego: "um ser que não pode falar aparece como incompletamente humano" (p.75).

Desde a confluência entre logos e língua, para parte dos linguistas, língua é, também, o que determina a forma de pensar o mundo e, nesse sentido, Jacques Hassoun (1979) também nos oferta a bela imagem de um "discurso que é carregado por uma língua”. Mas para além do discurso, da forma de pensar, como ignorar a também coincidência de sentidos que não nos permite dissociar a língua (discurso) falada pela língua (corpo)? E rapidamente podemos pensar no espanhol, italiano, francês, português e inglês que provêm essa mesma 
equivalência. O que, finalmente, faz com que não possamos deixar de viver a língua como atravessada pelo paladar, falar, comer, beijar. E, então, podemos nos perguntar: quais os limites que separam cada um desses verbos uns dos outros? Mais do que logos, língua é talvez uma das mediações mais radiais entre o corpo e todo o mundo externo.

Segundo Yankelevish (1993), é desde o século XVI que língua materna é chamada de língua da mãe. Essa que se refere à língua da mãe com seu bebê, em uma profunda variação de tons e pronúncias, ritmos e acentuações que vão muito além da inteligibilidade necessária para a comunicação básica de uma língua. Segundo o autor, é dessa forma que:

a mãe retoma as lalações do bebê e devolve-as e mostra todas as variações possíveis dos sons que este bebê está produzindo. Essa língua materna não é apenas a condição para que a criança possa incorporar a língua, mas a criança faz a prova de que os sons que ela emite são sensatos, já que há resposta (p.43).

De outro ângulo, só podemos tomar uma língua como materna, na medida em que também nos depararmos com outras línguas, as estrangeiras. Quem nunca se angustiou diante de uma língua estrangeira? Essa angústia do que pode ser a aventura de falar outra língua. Do que é a aventura de fazer uma viagem. Do que é poder encarnar (ou encarar), no próprio corpo, a experiência de ser estrangeiro. No próprio corpo porque, na grande maioria das vezes, nos defrontamos brutalmente com a limitação fonética que nos impõe outra língua, que nos impõe nossa própria língua. Essa limitação que, então, impede até às últimas consequências, de deixarmos de ser estrangeiros, que imprime nosso pertencimento originário à língua materna como uma marca indelével, inexorável, quase que como nossa carcaça.

Em "Budapeste", Chico Buarque fala: "devia ser proibido debochar de quem se aventura em língua estrangeira" (2003, p.5). De fato, nem todo mundo se arrisca no que pode ser a aventura de falar uma outra língua, essa própria também de uma viagem, essa que desvela, finalmente, para nós mesmos o lugar de uma inscrição primeira. Duas anedotas correntes tocam a problemática sobre o risco que se empreende na aventura de uma nova língua: nas ciências sociais, é conhecida a história de que em uma tribo, certa vez, um etnólogo observando aquela população, aprendendo seus hábitos e registrando tudo o que via, fora interpelado pelas crianças do grupo, que, ao lhe ver falando a língua da tribo perguntaram: por que você fala assim, como criança pequena? Deslocamento inquietante entre o lugar do cientista para o lugar da criança. Ou ainda, uma piada russa que diz algo 
como: "se eu pudesse me expressar em minha própria língua e você entendesse, você veria como sou inteligente". Falar uma língua estrangeira não é só confronto inquietante com o familiar, como Unheimlich (FREUD, 1919/2010), é também, constantemente se empreender em uma certa renúncia do lugar de onipotência, para poder, eventualmente, suportar o lugar infantilizado ou desinvestido pela cultura autóctone que toma língua como logos.

Aprender uma nova língua é, assim, nunca poder passar impune por ela, é carregar de forma implacável os resíduos do materno impressos no próprio corpo. Acento, sotaque, signos impressos no corpo. Eis o próprio corpo da língua, segundo Barbara Cassin (2012). Para a filósofa francesa, podem existir, para cada sujeito, línguas mais maternas que outras, e essas são às que somos convocados imediatamente a entender, essas que, em suas palavras, fazemos corpo. No entanto, em torno dessa discussão há uma tese fundamental defendida pela filósofa: a uma língua não se pertence, se aprende. Ao que poderíamos acrescentar: também se habita, ainda que provisoriamente, ou só de passagem, como em uma viagem.

No romance "O esquizo e as línguas", o estudante esquizofrênico (forma como se apelida o escritor estadunidense Louis Wolfson) narra sua relação peculiar com as línguas. Wolfson (1970) não pode mais falar sua língua materna, muito menos ouvi-la. Dói demais, invade demais, é como se cada palavra dessa língua entrasse rasgando em seu tímpano e permanecesse ecoando em uma intensidade insuportável. É demasiadamente enlouquecedor para o louco que pretende aniquilar sua língua materna. Para evitar o desconforto, para criar uma zona habitável no mundo, Wolfson se cerca de línguas estrangeiras que passa a estudar, compulsivamente, na tentativa de se armar, se instrumentalizar, se vestir, de algo que lhe permita, então, um pouco mais de contorno. Tomando as estrangeiras como referência, Wolfson pode até mesmo neutralizar a força monumental de cada palavra da língua materna. Como nem sempre é possível tapar os ouvidos apertando com toda a força seus tímpanos, o estudante de línguas esquizofrênico constrói uma nova gramática capaz de desconstruir qualquer palavra da língua materna, tornando-as estrangeiras através de sua própria estrangeirice muitas vezes etimológica. Podemos também pensar em Becket, que desde seu exílio na França não pôde mais escrever em língua materna. Ou também em todos os poetas que, como nos sublinha Caterina Koltai (2011), fazem recurso da possibilidade do exílio da língua.

Tendo em vista as reflexões sobre o trânsito e os diferentes pertencimentos às línguas, a questão sobre as possibilidades de uma análise em língua materna e em língua estrangeira se 
colocam de diferentes maneiras. Duas parecem ser as posições mais extremadas: de um lado, a ideia da impossibilidade de realizar uma análise em língua que não seja materna e, de outro, os benefícios de um processo analítico em língua estrangeira. Vamos à discussão de alguns autores da psicanálise que circulam por esses dois pensamentos, para em seguida, nos situarmos em relação ao debate.

Para Bernard Casanova (1982), psicanálise é a experiência da palavra em língua materna por excelência, uma vez que significantes são intraduzíveis. Nessa perspectiva, se levarmos em conta a noção freudiana do sonho como um rébus, poderíamos nos perguntar: como traduzir a compreensão hieróglifa do sonho de uma língua a outra? Todas as formações inconscientes, como nos lembra Casanova: "esquecimentos, lapsos, atos-falhos, trocadilhos e sintomas têm a mesma estrutura que o sonho e se referem à um certo funcionamento dos significantes da língua, em uma dada língua, não em todas” (p.29).

Ainda nesse pensamento, Judit Szekacs-Weisz (2004) nos coloca a seguinte questão sobre o processo analítico em língua estrangeira: "Simples palavras. Podemos encontrar as mesmas palavras em diferentes línguas - mas elas realmente têm o mesmo significado?” (p.76). Se partirmos da compreensão da intraduzibilidade do significante - havendo inclusive, para Casanova o risco de sua quebra no momento da tradução - é possível considerar as dificuldades de se empreender um processo analítico em língua estrangeira. Assim, para esses autores, língua materna imprime a formação inconsciente em uma intraduzibilidade que faz com que um processo analítico seja dificilmente possa ser levado à cabo em língua estrangeira.

No entanto, se língua materna é, por excelência, a língua em que se opera o recalque, Charles Melman (2000) defende, em contrapartida, outra posição:

Se falamos uma língua de empréstimo, participamos evidentemente do recalque próprio ao meio no qual estamos inseridos. Ou seja, como em geral, somos bem educados e procuramos não nos singularizar demais, é evidente que se trata, aí, de um recalque que podemos chamar de emprestado (p.15).

É desse postulado que esse autor propõe uma outra compreensão acerca do processo analítico em língua materna. Ainda que o recalque tenha se operado em um primeiro momento em língua materna, novos empréstimos podem se dar através das línguas estrangeiras, pois ao falar uma nova língua, passamos a participar, igualmente, do recalque próprio ao novo meio. Nesse sentido, se em país estrangeiro, o sujeito empreende uma análise 
em língua materna, dispõe-se a um forte risco de um efeito de cumplicidade com o analista, constituindo-se assim um obstáculo ao trabalho. Língua materna é para Melman também, de certa forma, a língua que favorece o incesto, a indistinção dos sexos e, portanto, a dimensão em que o outro não apareceria como radicalmente outro ao sujeito. Para Melman, a análise é possível em outra língua, sobretudo porque somos bilíngues em nossa própria língua: "cada língua organiza esse lugar Outro, que seria, portanto, no interior desse dispositivo que o problema do imigrante vem a se colocar” (p.21). Língua estrangeira é, assim, condição de estrangeridade para o processo analítico.

Todavia, em relação a esse debate, gostaríamos de pontuar também um terceiro lugar possível, esse justamente da passagem, do entre-dois do encontro entre línguas, esse auxiliado pelo atravessador no processo analítico. Aqui, a questão é menos sobre a necessidade de falar ou não a língua materna do analisando e mais sobre a escolha que daí pode ser feita, escolha, sublinhamos, tomada em função da transferência. Aqui, é importante pontuar que tomamos como transferência a dinâmica estabelecida na relação com o analista, isto é, um conjunto de afetos, palavras, vivências e experiências reeditadas no novo vínculo tecido entre dois. Com Nasio (1999), pensamos na transferência em seu caráter pulsional, que em referência aos destinos da pulsão, é possível compreender como a atividade do sujeito dirigida à figura do analista: tal como "um traçado pulsional que sulca a uma terra deserta que se tornará progressivamente um lugar, um vínculo: o vínculo da análise” (p.40).

Voltando à nossa discussão, sob a perspectiva da transferência, da mesma forma que uma língua estrangeira pode impossibilitar a transmissão de uma narrativa pela escassez de recursos da própria língua (ou pela impossibilidade de se acessar determinados sentimentos e experiências), também a língua materna pode nos deixar, muitas vezes, perto demais da experiência, por que não, tantas vezes mortífera.

Nesse sentido, por que não aproveitar dos recursos criativos venturosos que pode oferecer uma outra língua? Esse da possibilidade de reelaborar outramente. Falar do mesmo por um outro recurso. Voltar ao mesmo sítio, com outras roupagens. Se com nossas línguas maternas fazemos corpo, com as estrangeiras novas performances se oferecem. Trata-se, portanto, de se perguntar, em cada novo encontro, sobre a escolha da língua de atendimento. Muitas vezes, o analista escolhido é aquele que não fala (que não pode falar) a língua materna do sujeito - e é interessante notar como o desconhecimento de uma língua é vivido profundamente como a impossibilidade de falá-la, de compreendê-la. Mas o fato é que se por 
um lado a escolha da língua materna pode ser decisiva para o andamento e a permanência em um processo analítico, igualmente pode ser um fator de impossibilidade.

Certa vez, em um atendimento com um menino francófono, enquanto me contava suas histórias de aventuras, de repente ele me diz, em francês: "e então eu mergulhei dans la mèr(e)" - e simulou um mergulho com as mãos em direção a minha barriga. A homofonia da palavra Mèr(e), em francês, faz com que possamos ouvir ao mesmo tempo: mar e mãe. Mas, para além desse pequeno fragmento, há um outro elemento do caso que gostaria de sublinhar. Yerodin, recém-chegado ao Brasil, com seus 5 anos de idade, recusava-se a falar em língua materna, o lingala. Falava somente a língua do pai, o francês, que tampouco era sua língua materna, mas a língua que escolheu para se comunicar com seu filho, dentro de casa. "Yerodin é como seu pai, é muito inteligente, ele só fala francês, não sabe falar lingala, não fala nem uma palavra", me disse certa vez sua mãe. O pai de Yerodin está preso, ninguém sabe onde, nem por quanto tempo, muito menos se voltarão a vê-lo um dia. Sua mãe pensava que Yerodin não soubesse o que tinha acontecido com o pai, mas ele sabe muito bem: "o presidente Kabila prendeu o papai”, me contou um dia, em francês. É então habitando com unhas e dentes a língua paterna que Yerodin pode de alguma forma reatualizar a presença do pai, em seu próprio corpo. Já há quase dois meses no Brasil, e mesmo em contato com crianças lusófonas, Yerodin praticamente não falava português, insistia com seu francês, como se utilizasse de um recurso que lhe permitisse algum tipo de ancoragem para que o desaparecimento do seu pai não se convertesse em seu próprio desaparecimento agora em terra estrangeira.

É interessante notar a partir desse pequeno fragmento que aquilo que poderia ser lido como uma certa impermeabilidade de adaptação em um novo país - isto é a dificuldade de falar português como nova língua, adquire uma outra dimensão: a de recurso de sustentação de uma criança em terra de exílio. Esse é precisamente o ponto que gostaríamos de marcar como uma terceira via em relação ao debate entre as línguas do analista, isto é, sobre a importância da escolha da língua em função da transferência. Nesse sentido, em relação ao caso de Yerodin, podemos pensar que sem um manejo que levasse em conta a relação singular do sujeito com suas próprias línguas, a tentativa de ensinar ou impor uma língua fixa de atendimento parece ser uma violência com consequências psíquicas importantes. A recusa do português, em um primeiro momento, era o recurso possível de revestimento ao desamparo da chegada no exílio - exílio do próprio pai. Yerodin sabia que português era a minha língua 
materna, com frequência ele me via falar com outras crianças lusófonas, mas naquele momento, se dirigir a mim em francês era um recurso importante, que permitia ancoragem na transferência no contexto de uma família recém-chegada em uma nova casa. Anos depois, encontrei-me por casualidade com sua mãe, que me contou como Yerodin já com alguns anos a mais, frequentava com facilidade a escola e manejava fluentemente o português.

A intervenção do analista-coitote nesses contextos é o de possibilitar a passagem de uma língua a outra, para que do estanque, possa haver ponte e fluxos de trânsitos. Com Miriam Chnaiderman (2015), pensamos que em análise sustentamos a possibilidade de aprender uma outra língua, para que o sujeito possa deixar, então, de ser somente falado pela língua materna. Nesse contexto, o analista, falando ou não língua materna, sua ou do analisando, se situa precisamente nesse lugar da língua estrangeira, esse do encontro com o familiar mais estrangeiro. Há, nesse sentido, uma coincidência de lugares, e, nesse mesmo sentido, pensamos com Caterina Koltai (1997) em sua reflexão sobre o analista como o estrangeiro por excelência. Em nosso trabalho com migrantes, em alguma medida, somos nós que nos convertemos, de fato, em estrangeiros.

É importante sublinhar também que em todos os casos trabalhados até aqui e nos que virão a seguir, nos referimos, quase sempre, à encontros em línguas estrangeiras tanto para a analista como para os pacientes. Trata-se de uma língua terceira, portanto, tanto o francês, como o espanhol e o inglês. A título de exemplo, o francês falado no Brasil com pacientes congoleses, não é o mesmo francês falado na França. Aqui, pensamos nas vicissitudes do encontro entre um francês abrasileirado com um outro francês congolês. E não é só ao sotaque que me refiro, mas à todas as expressões empregadas, aos vocativos utilizados, e em tudo que é carregado pela língua. O mesmo com o inglês e também com o espanhol. Dois estrangeiros de uma língua, quase sempre língua colonizadora, mas que se encontram através dessa como um recurso possível de encontro.

Apostando então em um tratamento que possa se fazer valer de uma relação em que são reeditadas as experiências passadas, mas com novos recursos, sobretudo com a possibilidade de revisitar o vivido sem ser deglutido, mastigado, e triturado pelos tentáculos maternos da língua, nem do analista, nem do analisando. Fazer das línguas movimento e das fronteiras atravessamento é o que o analista-coiote pretende no contrabando (HASSOUN, 1994) de uma língua a outra, a passagem possível para fazer do duplo pertencimento, também dois lugares de enunciação para o sujeito. 
Duplo lugar de enunciação, a função do analista-coiote é de fazer do duplo pertencimento movimento e não barreira. Tendo em vista essa discussão sobre as línguas, seguiremos uma reflexão sobre a possibilidade de passagem e trânsito entre dois a partir de outro caso clínico.

\subsection{Cultura e desenraizamentos como problemáticas do deslocamento: o caso L.}

Muitas plantas, mesmo que em seus vasos, quando mudadas de lugar, morrem. Não suportam o deslocamento geográfico e a mudança de incidência da luz. Pessoas não são plantas, não têm raízes (TODOROV, 2008) fixas, por isso, sobrevivem e se reinventam nas possibilidades do deslocamento. Toda cultura, em alguma medida, é híbrida e mestiça, sua subsistência depende do encontro com outras, pois o encerramento em si mesma destina a tradição à museificação reificante ou à mimetização esvaziada de sentido. Nessa compreensão, a cultura e sua transmissão estão contidas no seguinte paradoxo: o de concomitantemente fundar e libertar cada sujeito forjado em seu interior, ou, ainda, trata-se daquilo que é imprescindível para se poder prescindir. Para Todorov (2008), ainda que todo ser humano sempre nasça no seio de uma cultura, isso não significa que ele esteja a ela destinado ou seja dela prisioneiro.

Sendo assim, o encontro entre diferentes culturas não implica na dissolução de nenhuma delas, mas na permanente possibilidade de novos deltas (HASSOUN, 1994), como um rio que se expanda com novas irrigações. No entanto, a relação com a cultura originária e seu pertencimento quase sempre operam em uma lógica filial. Isto é, trata-se de um rapport de natureza filial, em que os sentimentos são referidos, quase sempre, com o mesmo apego emocional que ao parental: pátria, língua mãe, país natal, o léxico empregado para se referir ao pertencimento cultural originário é revelador do tipo de laço. Por isso, fidelização e traição são elementos presentes nas formas de significar o deslocamento, o encontro com novas culturas e a fantasia de dissolução e perda da cultura originária em detrimento de outra. Mais ainda, a renúncia às insígnias fundantes do pertencimento originário, seja ele familiar ou cultural, não se dá sem custos. O caso L. ilustra nossa discussão. 
Em uma ocasião bastante inusitada, o funcionário responsável pela portaria da instituição me procurou para falar sobre um homem que estava no portão dizendo ter muita urgência de falar com algum psicoterapeuta. Fiquei surpresa, era a primeira vez que eu presenciava uma demanda espontânea de um refugiado à instituição, buscando diretamente o atendimento psicológico. Prontifiquei-me e fui ao seu encontro. Seu nome me tinha sido anotado em um pedaço de papel. Chegando na entrada, em meio a dezenas de pessoas, chamei seu nome e sobrenome, nenhuma resposta imediata, falei novamente, e, depois de um certo tempo, surgiu um homem grande, muito alto, impecavelmente vestido e de óculos escuros. Convidei que me acompanhasse até à sala, nos sentamos, me apresentei rapidamente e ele começou a falar, em francês:

"Estou muito mal, vou explodir, não estou aguentando mais, quero me matar. Estou querendo me matar. Disse a alguns amigos que estava a ponto de ceder, de me matar, e eles me disseram que eu viesse ver um psicólogo antes de tomar qualquer decisão. Não posso mais aguentar isso. Agora há pouco, quando você chamou meu nome, esse nome, eu...

Meu problema é o seguinte: não posso ouvir esse nome, cada vez que o ouço, sinto uma coisa horrivel, tenho vontade de vomitar em alguns momentos, em outros penso que vou cair no chão, às vezes me sinto como se fosse um assassino, alguém procurado, um bandido mesmo, mas muitas vezes, simplesmente, não respondo a esse nome, não me reconheço nele. Agora há pouco, quando você disse esse nome, eu demorei um tempo para me dar conta de que se tratava de mim.

Vou te contar minha história. Esse nome é falso, não é meu nome. E, por isso, viver com ele para mim hoje é insuportável. Não posso mais trabalhar por causa disso, não posso me inserir em um ambiente com esse nome. No meu passaporte consta esse nome e diz que sou do Benin, mas isso é falso, esse passaporte é falso. Sou do Togo, não do Benin. Cheguei no Brasil há dois anos, fugindo de problemas que tive com meu pai, no meu país...

Meu pai é um chefe de Voodoo, um homem muito importante, um grande líder espiritual. Um homem de muito poder e muito reconhecimento. Atualmente, ele está velho, tem mais de oitenta anos, e todo o problema começou quando ele decidiu que eu deveria substituí-lo como chefe de Voodoo. Não aceitei, nunca aceitaria, não posso fazer isso. Não quero isso para minha vida. Não acredito nessa religião. Sou cristão. Veja só, até baixei a 
bíblia aqui no meu celular, estou sempre perto dela. Mas meu pai nunca aceitou isso, e então começou a me ameaçar. Ele matou minha filha. Minha terceira filha, que tinha um ano e meio, morreu de repente, de uma parada cardíaca. E dias depois, ele me confessou, tinha sido ele. Meu pai matou minha filha. Sim, foi um feitiço. Meu pai pode, por exemplo, estar aqui com a gente nessa sala, e de repente, desaparecer. Ele tem esses poderes, ele tem muitos poderes. Depois da morte da minha filha, ele me disse que eu teria sete dias para aceitar a nova função senão eu também seria morto. Foi quando fugi. Fui até o Benin, consegui esse passaporte falso e embarquei para o Brasil. E chegando aqui, já logo no começo, passei a sentir essas coisas. Nunca tive isso, eu era um homem normal, cheio de energia, vivo, e agora, penso que vou enlouquecer, não sei”.

Pergunto seu nome verdadeiro, descubro que são três, e que em Ewé - sua língua materna e etnia de pertencimento - compostos na seguinte ordem: sobrenome da família (ele, em sua ascendência paterna, representa o oitavo da geração de seu sobrenome), um nome próprio e um nome que indica seu pertencimento étnico. Seu nome próprio traduzido para o português é algo como: rei supremo, ou o rei dos reis.

Peço que L. fale sobre sua configuração familiar, e ele me conta sobre ser o caçula da família, o menino mimado e querido por todos, o filho mais amado por sua mãe e também pelo pai. Antes de L. nascer, sua mãe era casada com um homem que não era seu pai, e que depois de seu nascimento, passou a ser seu padrasto. Juntos, já tinham quatro filhos. Certo dia, esse homem, marido da mãe, partiu em viagem de trabalho a outros países africanos, o tempo passou, ele não retornou, e chegaram à mãe noticias de que ele nunca mais voltaria. É quando a mãe conhece o pai de L., que durante a juventude havia sido seminarista, mas anos depois, decidiu romper com o cristianismo e resgatar a religião de seus ancestrais, tornando-se o maior chefe de Voodoo da região. De um encontro apaixonado, nasce L. Mas quando sua mãe ainda estava grávida, quase como surpresa, o padrasto retorna ao Togo.

Nesse momento da narrativa, L. diz, assim como se tivesse sido pego de surpresa: “ $A h$, olha só, não te disse, esse nome falso que escolhi é o nome do meu padrasto". Assim, como se nunca tivesse feito antes essa ligação tão evidente. Voltando logo à narrativa, contou que naquele momento, sua mãe e todos os filhos voltaram a viver com o marido, e suas outras três mulheres, e outras dezenas de filhos. "Vocês eram quantos?", pergunto com certo espanto. E ele me responde, gargalhando, que eram muitos. Então, me olha novamente e diz: "Nossa, há quanto tempo que não dou uma risada. Nem sabia mais o que era isso. Me sinto mais leve". 
Desenraizamento, desfiliação, desfidelização, L. narra sua trajetória entre dois pertencimentos, duas famílias, duas religiões e o transtorno gerado ao se refiliar, em fuga, com o outro nome, em outro país, e com outro pai. Criado por seu padrasto, por quem conta sempre ter sido considerado como filho, L. foi criado no cristianismo, mas sempre manteve contato com seu pai, de quem, entre a centena incontável e desconhecida de filhos que têm, era o preferido, o escolhido. Nas visitas frequentes à casa de seu pai, L. aprendeu diversos rituais, viu pessoas serem curadas, viu com admiração e temor a onipotência do pai, com fascínio, mas também com muito medo de tudo o que considerava o lado maligno dessa religião, isto é, os sacrifícios e o poder de fazer mal aos outros.

Em uma mesma fala, L. era capaz de dizer: "Não acredito nessa religião, não acredito em feitiço. Isso tudo não existe. Mas sei que vou morrer disso um dia.”. Ou, então: “Eu não posso substituir meu pai, não quero, não posso, sou cristão. Aprendi muita coisa com meu pai, observando seus rituais. Certa vez, salvei meu filho do meio. Durante a noite, ele teve um ataque epilético e, quando fiz o ritual, o ataque foi interrompido imediatamente". Quanto mais L. tratava de negar sua filiação, mais a presença de seu pai se intensificava. Como feitiço, pelo pavor de ser vítima de uma magia, ou de ele mesmo vir a manipular alguma magia para o mal. Mas o fato é que na tentativa defensiva de se desfiliar, L. escolheu justamente portar o nome de seu padrasto. E isso, efetivamente, não foi possível, e L. entrou em uma crise aguda de angústia.

É importante sublinhar o fato de que essas problemáticas ligadas à transmissão do sujeito tornem-se lugar de eclosão do traumático precisamente no exílio. Isto é, no caso L. foi no exílio que se toda sua problemática de duplo pertencimento e filiação veio se reatualizar em sua dimensão mais disruptiva. Podemos pensar, desse modo, que é sobretudo nos movimentos de desterritorialização que a problemática singular de cada sujeito vem se remontar, revelando, assim, precisamente nesse deslocamento, os limites, esgarçamentos e possibilidades dos seus próprios recursos.

Sobre a possibilidade de remontagem a partir de um duplo no processo de desterritorialização, Robert Neuburger (2009), comentando sobre a vida do etnopsiquiatra húngaro Georges Devereux, conta a seguinte passagem:

Georges Devereux, quando nasceu, chamava-se Gyorgy Dobó, e depois dos vinte anos, já na França, em 1932, ele se converte à religião católica e passou a ter o nome que é conhecido até hoje. A escolha deste patronímico é 
ainda mais tocante quando pronunciada em húngaro, significando: Judeu! Podemos ver aí a marca de um interesse precoce pela questão de mascarar a identidade e de sua função, que seria justamente a de se revelar mascarando (p.6).

$\mathrm{Na}$ tentativa de fugir de sua identidade terrorífica referida ao pai, L. também revela mascarando-se, pois, para fugir do pai, elege nada menos que a identidade de seu padrasto. Ao longo dos atendimentos, L. descreve com frequência todas as suas semelhanças com o pai: "Nós somos fisicamente iguais, todos os homens da família do meu pai são assim, como nós dois, somos carecas, temos a mesma cara, temos todos os dentes perfeitos, veja só meus dentes, todo mundo me pergunta se são de verdade e meu pai com mais de oitenta anos nunca perdeu nenhum um só dente".

Mas a identificação é também aterrorizante, quase como se lhe desse um poder que ele não pudesse conter: "Vou te dar um exemplo sobre o poder do feitiço. Estava lá na sala de espera agora há pouco e do meu lado tinha uma mulher deficiente e que estava muito comprometida. Em volta dela, algumas crianças estavam fazendo piadas, caçoando ela, provocando, e, nitidamente, aquilo a incomodava, mas ela não fazia nada. Eu fiquei lá olhando aquilo tudo e pensando que se eu fosse um chefe de Voodoo jogaria um feitiço imediatamente naquelas crianças, para que tudo o que estavam fazendo com aquela mulher voltasse contra elas algum dia. Percebe como funciona?".

Presença massiva e ambivalente, o pai de L. era tanto figura temida como admirada. Ao longo das primeiras sessões, percebo que um dos elementos que desencadearam a crise mais aguda de angústia em L. foi o fato de sua atual mulher, uma brasileira, estar grávida. Aí a questão da transmissão e da filiação parece ter também se reatualizado. "Como posso transmitir esse nome falso à minha filha? Nunca poderia fazer isso". Nome falso, sim, mas não qualquer nome, o nome que remetia a uma filiação ideal, fora da traição de sua mãe com seu pai, o nome de sua criação cristã com aquele que fora por toda a vida de sua mãe seu legítimo marido, e também o pai de todos seus irmãos, mas não o seu. Um nome impossível de se transmitir. Ao largo das sessões, L. quer retomar seu nome verdadeiro, nome pelo qual desde o nosso primeiro encontro me pediu para que o chamasse.

Passados alguns meses, L. consegue mudar de nome e retomar seu - verdadeiro patronímico. Adquire novos documentos e escolhe dar à filha o nome de sua mãe. Quase como que de volta a seu verdadeiro nome, L. pode conceber outra vez. É nesse momento que L. diz sentir-se "desinchado" por dentro, e, passado algum tempo, depois do nascimento de 
sua filha, decide procurar seu pai, a quem telefona certo dia. É quando seu pai, aliviado de saber que está vivo em alguma parte, lhe pede desculpas e diz que mentiu sobre a morte de sua filha, e pede insistentemente que volte ao Togo, diz que ele não irá mais exigir a substituição.

L. opta por ficar no Brasil, diz querer investir em sua nova família e planeja trazer os outros dois filhos um dia para o novo país. Entre a diversidade de seus duplos pertencimentos: duas religiões, dois pais, dois países, L. pareceu ter feito de um terceiro a possibilidade de revistar e circular entre os dois. Certo dia, em sessão, L. diz: "Esses dias eu fiquei pensando: por que não confrontei meu pai quando estava lá? Sabe, eu pensei realmente que fosse morrer. Mas se minha decisão foi vir para cá, penso agora que tenho que confrontar os problemas aqui, todos eles, os de lá e os daqui. Essa é a conclusão que tenho no momento".

Pelo terror de um pai impossível de substituir, a transmissão de L. estava interrompida. Ao se mascarar com o nome do padrasto, L. revela uma filiação ideal, mas que não lhe pertence, e, mais ainda, filiação que trai sua própria tradição, e se converte em crise, pela impossibilidade de transmitir. Por acreditar demais na onipotência de seu pai, pela presença excessiva em si, L. precisou ser outro, precisou cruzar o oceano, até que no exílio, experenciando seus próprios confins, pôde voltar a se haver com o que lhe tinha sido transmitido, mas desde um outro lugar, para, então, poder ser outro em nova terra. Da possibilidade de conceber e voltar a transmitir, L. fez do Brasil o país terceiro para circular entre seu duplo pertencimento.

Com esse caso, gostaríamos de ilustrar a potencialidade da crise em um contexto de desterritorialização. A partir das problemáticas singulares do sujeito, a crise eclode no exílio, mas diante disso, se dão as mesmas possibilidades de remontagem em um novo contexto. Isto é, justamente a partir da conflitiva, a possibilidade de sua remontagem e de trânsito, deslocamento e passagem para fazer do deslocamento geográfico também um deslocamento do próprio sofrimento, instaurando, assim, a dimensão do duplo pertencimento, também como duplo lugar de enunciação. Seguindo nessa problemática, abordaremos a seguir, através de um outro caso, algumas dessas questões. 


\subsection{Obi entre dois}

Obi já estava no Brasil há mais de seis meses quando nos vimos pela primeira vez. Nesse primeiro encontro, contou-me ter passado os seis meses praticamente sem sair de casa, sem sair da cama. Chegando em São Paulo, depois de alguns dias em um hotel, Obi alugara uma pequena quitinete na zona leste da cidade, e, de lá, só saia para comprar algumas comidas e voltava para a cama. Dizia-me não ter força para nada, só se mantinha vivo, ainda sem saber direito para quê. Também tinha bastante dificuldade em falar, era preciso de tempo para ouvi-lo. Algum tempo depois, vim a entender que sua dificuldade de falar naquele momento era dupla e revelava tanto a presença implacável de sua experiência de perda, como da vergonha em anunciar, para um outro, sua orientação sexual.

No início, custei também a entender o inglês de seu país, e, ele mais ainda o meu. Já logo ficava claro que havia entre nós uma forte disponibilidade, das duas partes, pelo menos de nos fazer compreender. Parecia que depois de seis meses, Obi tivera alguma força a mais, suficiente para sair da cama e vir pedir ajuda, ainda sem saber direito como. Reconhecia que estava mal demais. Com Rosa (2016), pensamos que já no ato da demanda de atendimento há algo de um mínimo de narcisismo operando, esse que é capaz de reconhecer que se está sofrendo demais, que é preciso de ajuda.

Obi era um homem enorme, muito forte, com uma beleza delicada, e, com isso, me pegava pensando que talvez tivesse tido uma infância confortável, cercado de carinho e proteção. Algum tempo depois, me contou que apesar de viver perto dos pais e irmãos, havia sido criado na casa de sua avó. Neto mais próximo, aos nove anos mudou-se para casa da avó, onde viveu toda sua juventude. Aos trinta e três anos, Obi era agricultor e possuía algumas propriedades no oeste africano onde produzia alimentos junto com seu marido. Tinha uma vida confortável, viajava muito e passava todo o tempo gerenciando suas fazendas em diversos países. Por quase dez anos, tinha vivido uma relação amorosa com um homem, um amigo de infância, que havia reencontrado quando adulto.

Obi vinha da Nigéria, do interior do país, e pertencia à etnia Igbo, que dá nome à sua etnia, ao seu povo, e à sua língua. Trata-se de uma das três etnias mais importante da Nigéria. Foi com a literatura de Chimamanda Adichie que meu universo sobre os Igbo se ampliou para além daquilo que me narrava Obi. Com os livros de Chimamanda e com as narrativas de Obi sobre seu povo, soube um pouco mais sobre a guerra de Biafra, sobre a perseguição aos Igbos pelos outros povos, do papel dos colonizadores ingleses no conflito, e da luta desse povo 
separatista para ter um Estado. Nas sessões, quando começava a me contar sobre sua etnia, desatava a falar com a fluência que justamente eu não via quando chegou. Quando se tratava de seu povo, Obi fazia questão de me contar o máximo de detalhes, me contava sobre histórias, valores, me mostrava fotos, músicas, vídeos, traduzia palavras, provérbios, contavame de hábitos e costumes. Mas tudo isso só apareceu depois. Voltemos ao início.

Obi contou-me que durante dez anos viveu sua relação amorosa de forma clandestina. Tomavam todas as precauções para não passarem muitas noites juntos no mesmo local e não chamarem a atenção de vizinhos, assim como não deixavam transparecer aos empregados e muito menos às famílias. Obi e seu companheiro sonhavam em viver juntos no Brasil, país em que acreditavam poder, um dia, viver livremente sua relação. Já tinham acumulado bens e dinheiro suficiente para sair do país, vender algumas fazendas e gerenciar outras à distância. Juntos conseguiram o visto brasileiro e planejavam viajar durante a Copa do Mundo.

Poucos meses antes do projeto de viagem do casal, Obi recebeu um telefonema dizendo que a polícia havia invadido sua casa e levado seu companheiro e um amigo para a delegacia, e o aconselhavam a não voltar para casa naquela noite. Em seguida, foi para a cidade de sua família, e dois dias depois, o amigo que tinha sido também detido conseguiu avisar que seu companheiro fora morto pela polícia. Na ocasião, a relação do casal é revelada, Obi passa a ser procurado pela polícia e sua família o expulsa de casa, dizendo que ele havia transgredido o que de mais essencial havia em sua cultura. Mãe e tios ameaçam entregá-lo à polícia. Obi chega ao Brasil sozinho, tendo perdido um amor pela brutalidade de um crime considerado legal em seu país, e rechaçado pelas leis de sua etnia.

A dor pela perda do marido transbordava em um silenciamento que, durante seis meses, o deixara praticamente sem sair da cama. Em nossos primeiros encontros, Obi contava-me sobre seu amor, sobre sentir-se sem seu maior ponto de referência, sobre estar sozinho no país em que sonhava viver plenamente a vida de um casal. Contava-me também sobre a vida de troca e companheirismo que tinham, da experiência de terem se conhecido e vivido intensamente uma relação apaixonada. Como viver sem ele, como viver o sonho em comum pela metade? Eram perguntas implacáveis que, com o desenrolar das sessões, também se desdobraram em questões acerca de sua homossexualidade. Experiência ambivalente de luto, concomitante a essa narrativa, Obi passou também a questionar: "sou doente? Como posso me curar? Me curar de ser gay. Você consegue me curar disso?" 
Nessa circunstância, passou a ter sonhos repetidos que variavam em torno de uma cena comum: ser flagrado transando com um homem, e em seguida ser perseguido pela família. Em um dos sonhos, Obi está na cama com um homem, quando sua mãe abre a porta e flagra a cena de sexo entre os dois. Assustado, o casal começa a se cobrir enquanto a mãe grita e chama a atenção de toda a família na casa, e assim mobilizando todos - tios, primos, irmãos, para uma perseguição que resultaria em sua morte.

Em outra sessão, Obi chega contando que assistiu a uma notícia que o abalara especialmente. Conta ter se impressionado com uma criança que, após ter sobrevivido a uma queda de um avião no meio de uma região deserta, de estar ferida e ter perdido todos seus familiares, correu sozinha por mais de dez quilômetros até conseguir ajuda. Obi se diz impressionado com sua força, se pergunta como uma criança tão pequena pôde ter feito tanto. A fuga pela sobrevivência é algo que Obi conheceu de perto, vivência, no entanto, marcada duplamente pela culpa de estar vivo. Estar vivo e poder construir o projeto de viver livremente sua homossexualidade - em um país que, pelo menos legalmente, não criminaliza essa prática - mas sem seu amor; e estar vivo perante sua família e toda sua etnia, que havia lhe condenado à morte por ser homossexual.

Assim, na medida em que Obi começava a recuperar forças e o trabalho de luto acontecia, uma nova questão passou a tomar corpo: a de como ser um homem gay e igbo concomitantemente? Para ele, esses dois pertencimentos diziam de mundos irreconciliáveis. Contava-me que dentre todos os crimes, a homossexualidade era o único em que não havia nenhuma pena prevista de punição ou regulação interna em sua etnia. Para os crimes de homicídio, roubo, adultério, todos esses, havia a pena de prisão, ou alguma forma de restituição ou regulação; para a homossexualidade, o crime hediondo em Igbo, apenas a morte ou o exílio - como fuga da morte. Assim, ser um homem igbo e gay dizia de um abismo em que Obi não via possibilidade de transitar.

Vivendo sua relação amorosa clandestinamente, era possível (em uma montagem frágil e delicada) ser socialmente um homem igbo, mas na medida em que sua homossexualidade se tornou pública, o exílio passou a ser destino. E precisamente essa cena reatualizou-se no Brasil, na medida em que Obi voltou a ter forças para retomar os cuidados de sua vida.

Com o passar do tempo, a militância Igbo tornou-se um recurso para voltar a cuidar de si. Assim, passou a ocupar-se disso em todos os seus dias e noites, tornou-se ativo em um 
grupo que promovia sua etnia em todo o mundo, e passou a trabalhar incessantemente. Seu telefone nunca parava de tocar, e ele sempre me pedia para atender durante as sessões. Funcionamento cindido, para ser Igbo novamente, Obi precisava voltar sua homossexualidade para o armário, e como militante, passou novamente a se esconder.

Concomitante a esse movimento, Obi começou a falar do desejo de telefonar para sua mãe. Desejo atravessado por muito medo de ser rejeitado, e pelo ressentimento de nunca ter recebido nenhuma mensagem, nenhum email, nem de suas sobrinhas ou irmãs mais próximas. É quando já um pouco mais distante do terror de ser morto, Obi passa a enunciar: "não é possível que em nenhum momento elas não queiram saber onde estou, como estou...”. Após semanas de muita hesitação e falando, nas sessões, do universo de medos envolvidos, toma coragem e liga para a mãe. "Ela não desligou o telefone, e sei que isso significa muito", me disse. 'Liguei, falei: 'Alô, sou eu' ela respondeu: 'alô', não falou mais nada, mas não desligou o telefone, ficou na linha, me ouvindo por algum tempo. Pude sentir que ela não me rejeitou. Voltarei a ligar novamente”.

A militância figura para Obi como um processo profundo de politização, foi quando começou a se dizer novamente conectado com seu povo, com as causas de sua etnia. Nesse contexto, passou a estudar história, geografia política e ser ativo em diversos meios. No entanto, esse movimento se dá em continuação à clivagem anterior. Em seus grupos, Obi é apenas um homem Igbo, sua homossexualidade é mantida em absoluto segredo, e todos os cuidados são tomados. Nas sessões, ocupadas pela narrativa quase maníaca de suas atividades, também cada vez menos trazia questões ligadas à sexualidade. Esse tema desaparece, eu o faço notar, e quando surge, é apenas para responder o que lhe pergunto.

Passado algum tempo, Obi começa a circular na vida noturna em São Paulo, passa a ter seus primeiros encontros após a morte de seu companheiro e acaba consolidando um grupo de amigos. Movimento eclipsado, agora Obi parecia poder circular nessa dimensão e voltar a se haver com o próprio erotismo. Alguns meses depois, tem um encontro marcante com um rapaz a quem passa a namorar. Obi dizia que esse moço era capaz de compreender o que ele havia vivido, e isso bastava para um profundo respeito e admiração recíproca.

Algum tempo depois, Obi deixa de vir às sessões. Despede-se grato por ter podido atravessar um momento de crise, mas diz que agora é tempo de viver, e nos despedimos. Obi restitui seu funcionamento entre dois: reencontra seu pertencimento Igbo, longe da família, e refaz um laço afetivo e erótico com outro homem, no âmbito privado. Assim, também se 
apropria do projeto de viver no estrangeiro, e faz do exílio não só destino forçado, mas também deslocamento propulsor de desejo. A dimensão entre dois que Obi parecia operar, através de seu duplo pertencimento, com a experiência-limite do assassinato de seu marido e a rejeição de sua família, tornou-se estanque. Depois, à medida do trabalho de luto, foi possível revisitar seus pertencimentos fazendo circulação e duplo lugar de enunciação na vida: homem Ibgo e homem gay, Obi deixou de estar entre dois para poder ser os dois, entre todas as possibilidades de novas remontagens.

Através dos dois casos trabalhados, é importante sublinhar que em um primeiro momento, a função da escuta parece operar pela via da ancoragem - isto é, a de um endereçamento que, ancorado na escuta do analista, cria condições para que o sujeito diante de seus próprios recursos, se responsabilize pela dimensão de escolha do deslocamento; por outro lado, podemos sustentar a escuta como mola de significações (ROSA, 2009), elemento propulsor de desejo, trata-se não só dos destinos criativos de reinvenção do sujeito, mas da possibilidade de trânsito e circulação. Assim, pensamos concomitantemente a posição do analista nesse contexto pela figura do atravessamento e da passagem para fazer do duplo potência de desejo e não estanque. Isto é, intervenções que possibilitem que cada sujeito faça uma escolha, a seu modo.

Tendo em vista essa discussão, através da ilustração do caso de Obi, abordaremos a questão das injunções institucionais presentes na clínica e o lugar do analista em face dessa problemática. Dissemos sobre as línguas e culturas presentes nos atendimentos, agora nos debruçaremos sobre a problemática dos papeis presentes na clínica.

\subsection{Elegibilidade, a questão da verdade e as injunções institucionais: o caso dos solicitantes de refúgio por orientação sexual}

A elegibilidade e a questão da verdade na narrativa dos sujeitos solicitantes de refúgio são elementos centrais nos atendimentos nesse contexto. Como vimos, a decisão das instâncias de elegibilidade sobre as solicitações de refúgio utiliza, como principal critério, a coerência da narrativa do demandante acerca das razões que o impeliram ao deslocamento. De saída, um impasse moral está colocado: a necessidade de forjar e adaptar narrativas críveis pelos dispositivos de elegibilidade de cada situação. Em outras palavras, trata-se de construir uma narrativa passível de garantir a própria sobrevivência. No primeiro capítulo, tratamos 
sobre os critérios de elegibilidade para a solicitação de refúgio que estão estabelecidos pela Convenção internacional e a jurisprudência de cada país. No entanto, a singularidade de cada caso faz com seja necessário adaptar aquilo que é de natureza rígida e objetiva da lei para a complexidade das vivências subjetivas.

Com esse impasse estabelecido, várias problemáticas se apresentam: a regência da lógica da suspeição em torno da narrativa do refugiado; a necessidade de adaptar a própria história (nunca sem custos) a fim de garantir sua credibilidade - com supressões ou adições de passagens ou elementos que muitas vezes terminam por fazer o sujeito perder-se mais ainda sobre si mesmo; o condicionamento à elegibilidade por empatia, isto é, quanto mais eloquente, ou quanto maior a capacidade em transmitir e emocionar o oficial de elegibilidade, ou ainda, quanto maiores forem os compartilhamentos culturais comuns, mais fácil a aceitação; entre outras. Sobre esse tema, Didier Fassin (2017) comenta:

Progressivamente, a verdade como coerência tomou um lugar mais importante. A maneira pela qual a pessoa se apresenta diante daqueles ou daquelas que irão decidir sua sorte, as vestimentas que ela porta, as atitudes que ela adota, as emoções que ela manifesta se tornaram significantes [...]. Oficiais e magistrados não hesitam, inclusive, a recorrer, para interpretar esses signos, à teorias culturalistas profanas que eles possam ter adquirido em uma experiência pessoal, uma viagem turística, um livro lido (p.26).

É o magistrado que decide sobre a verdade acerca da narrativa do solicitante de refúgio e, nesse sentido, cabe também a ele decidir sobre seu direito de se instalar onde pretende. Assim, a separação entre imigração e refúgio é própria da jurisprudência, não da clínica. Portanto, ainda que eventualmente inserido em equipamentos que respondam à lógica legal de concessão de refúgio somente para aqueles que logram provar uma perseguição, ou seu fundado temor, o trabalho clínico opera em outro registro.

Se diante dos oficiais de elegibilidade, da corte, do tribunal, ou de sua defesa, no caso de outros países, a permanência dos sujeitos depende, em grande medida, da credibilidade e coerência de sua narrativa, na relação analítica que se constrói em espaços de trabalho próprios da clínica, tratamos de fazer com que a verdade dos fatos - essa que, paradoxalmente, é fiadora da possibilidade de permanência ou não no novo país - possa estar suspensa. Nesse sentido, a verdade que levamos em conta é a do discurso, enredado nas tramas da fantasia e que se faz chegar até nós, na maioria das vezes, transbordado pelo sofrimento psíquico. É através da dimensão da experiência que, segundo Ana Costa (2013), 
pode ser tomada "tanto no sentido dado por Walter Benjamin, no da possibilidade de sua transmissão, quanto amparada nos fundamentos da psicanálise, na produção de condições possíveis para que o sujeito se situe na relação à falta" (COSTA, 2013, p.1), que tomamos a vivência dos sujeitos que chegam até nós.

A narrativa que nos é endereçada - tenha ela ocorrido ou não da forma como enunciada - é nosso material de trabalho, e mais do que a verdade dos fatos (novamente, se aquilo ocorreu concretamente ou não) nos debruçamos sobre as formas como cada sujeito se conta para um outro. Poder se oferecer, na transferência, como figura apartada da lógica de suspeição cria não só condições de estabelecimento da confiança e da possibilidade de emersão da palavra, como a chance de o sujeito contar suas "verdades" ou "mentiras" (e eventualmente poder circular entre elas) sem que isso tenha efeitos jurídicos em sua permanência no novo país.

Porém, não raro, psicoterapeutas são convocados pelas instituições em que estão inseridos para atestar de alguma forma a verdade dos discursos. Geralmente, as demandas são feitas através de perguntas sobre a possibilidade de que a narrativa consista em um delírio, evidenciando a condição patológica do solicitante, ou numa "mentira". Em face disso, insistentemente recusamos o lugar forense da psicologia.

Entendemos, no entanto, que não se trata de nos isentarmos inteiramente da questão. Se, de um lado, não podemos fazer com que nossos espaços de trabalho clínico se tornem delegacias policiais (DOUVILLE, 2014), que operam sob a lógica da suspeição, de outro, não podemos fazer como se essa questão não nos interpelasse. As formas pelas quais cada sujeito vai se haver com a própria história e transformá-la em narrativa coerente para os dispositivos de elegibilidade incidem como injunções institucionais nas vivências e percursos das pessoas em deslocamento. Por isso, o tema é caro para pensarmos nas formas como se dão as experiências de deslocamento em país de exílio e as possibilidades de intervenção clínica.

A rebote do caso de Obi, tomemos a questão dos refugiados reconhecidos por sua orientação sexual, para nos aprofundarmos em alguns pontos sobre as injunções institucionais presentes nesse contexto e seus desdobramentos subjetivos. Como vimos anteriormente, na Convenção de 1951, não há nenhuma menção sobre aspectos de gênero ou sexualidade. No bojo das mobilizações dos movimentos feministas e homossexuais dos anos 1990, alguns países da Europa Ocidental e Estados Unidos passaram a aceitar cada vez mais pedidos de refúgio por orientação sexual. Segundo a antropóloga Norma Mogrovejo (2006), casos assim 
configuram-se como o que ela cunhou como sexílio, isto é, a alternativa política para dissidentes sexuais, a possibilidade de um exílio sexual. Segundo Mogrovejo, trata-se de uma “estratégia que preserva as garantias de transformação social, direito à escolha, autodeterminação das pessoas, liberdade individual, direito à diferença e à dissidência, bases para uma democracia” (p.5).

Desde então, diversos países, como é o caso do Brasil, vêm sistematicamente reconhecendo solicitantes de refúgio por questões de sexualidade e gênero como perseguição por grupo social. No Brasil, a prática de reconhecimento pelo CONARE de solicitantes em função da orientação sexual é corrente. Vitor Andrade (2017) contextualiza os casos em que têm sido reconhecidas as solicitações de refúgio. Segundo o pesquisador, tanto os sujeitos que se identifiquem como homossexuais em países em que a prática é criminalizada, como em países em que não é, se o temor de perseguição for fundado, há a possibilidade de reconhecimento da solicitação de refúgio. O mesmo é previsto para os sujeitos que não se reconheçam ou tenham práticas homossexuais, mas sejam vistos pelos perseguidores como tais ou como tendo práticas não-heterossexuais, e igualmente para sujeitos que tenham desejos por pessoas do mesmo sexo, sem nunca terem tido nenhuma experiência precedente. Trata-se, então, do reconhecimento pelas instâncias de elegibilidade da perseguição ou do temor em função da orientação sexual ou identidade de gênero. No entanto, o estabelecimento de critérios de verdade e elegibilidade nesses casos não parece ser evidente.

Ainda segundo Vitor Andrade (2017), em alguns países são exigidas provas sobre a orientação sexual dos solicitantes que resultam em critérios bastante arbitrários de elegibilidade e de busca pela verdade:

Há relatos de que a Inglaterra já pediu que 204 solicitantes lésbicas mostrassem fotos íntimas com suas companheiras a fim de provar sua lesbianidade. Na República Tcheca, até pouco tempo atrás, eram exibidos filmes pornográficos a fim de se realizar testes de excitação com solicitantes homens que alegavam serem gays. Há relatos também de testes médicos a fim de verificar o ânus de solicitantes homens que afirmam serem gays. Evidentemente, essas formas de se exigir um teste físico, uma prova médica, acerca da orientação não-heterossexual violam os direitos humanos dessas pessoas, além de possuir um entendimento fisiológico da sexualidade, descartando seus aspectos subjetivos (as situações, por exemplo, que apesar de as pessoas possuírem desejos por outras do mesmo sexo, não manifestaram esses desejos); ao invés de lhes garantir proteção, esses Estados lhes colocam em uma situação de maior violência (p.199). 
Nesse sentido, como não pensar as modalidades de jurisdição do íntimo (KOBELINSKY, 2012) como desdobramentos dos discursos moralizantes das práticas homoeróticas? O caso de sujeitos bissexuais ou de solicitantes de refúgio perseguidos por sua orientação sexual, mas que têm filhos, e todo o universo de homossexualidades (PORCHAT, 2015) são ainda mais passíveis de serem julgados em função de critério arbitrários. A antropóloga Carolina Kobelinsky (2012) em etnografia sobre a elegibilidade de casos de solicitantes homossexuais na França com juízes propõe a seguinte reflexão:

\begin{abstract}
Nos casos fundados na orientação sexual, os juízes põem geralmente em questão a homossexualidade do solicitante e esperam ver na audiência um gay" [...] "A ideia de que a homossexualidade é algo visível, que se pode detectar facilmente durante a audiência é compartilhada por muitos juízes da corte [..] De fato, costumam recorrer a estereótipos no momento do encontro cara a cara com o solicitante. A imagem do "gay afeminado", ou em todo caso, a redução da homossexualidade ao afeminado, mobilizada por alguns juízes da Corte cristaliza um conjunto de percepções e valores a partir dos quais se constrói o que os atores do universo jurídico francês e seu conjunto denominam de intime conviction (íntima convicção) do juiz (p.25, tradução livre).
\end{abstract}

A expectativa dos juízes franceses de ver um gay na figura do solicitante de refúgio, relatada por Kobelinky (2012), configura a parcialidade de se recorrer a insígnias não só estereotipadas como culturalmente circunscritas, ou, em outras palavras, trata-se de não ver o sujeito que se apresenta diante do magistrado. Muitos dos que se deslocam por razões de perseguição por sua orientação sexual, vindo dos rincões mais remotos do globo, por vezes, desconhecem a relação de suas práticas homossexuais com signos do movimento LGBTI internacional, e mais ainda, orientação sexual não define um comportamento social padronizado. Assim, a chamada convicção íntima dos juízes para decidir sobre os casos, figura como um conjunto moral regido pela lógica da suspeição do refugiado.

Objeto, portanto, sempre de suspeição, o solicitante de refúgio é tomado pela coerência de sua narrativa aos olhos do magistrado, e como desdobramento, duas categorias morais se impõem junto à interpretação de seu discurso: a da produção da vítima ou do suspeito. Pois se o que o sujeito diz é verdade, trata-se de uma vítima de perseguição, se é mentira, estamos diante de um suspeito que pretender forjar uma narrativa para se instalar no país. Particularmente, no caso dos solicitantes de refúgio por orientação sexual, vemos as modalidades de jurisdição do íntimo capturadas por discursos moralizantes da norma heterossexual e cultural que não cessam de produzir violência. 
O caso dos solicitantes de refúgio por orientação sexual nos dá elementos para pensar a problemática da elegibilidade e da questão da verdade das narrativas como injunções institucionais que incidem nas vivências dos sujeitos que trabalhamos. Somos convocados a problematizar essas definições e funcionamentos institucionais sobretudo pelos efeitos de subjetividade que produzem. Nessa mesma compreensão, a questão da documentação, ou simplesmente dos papéis, tem valor semelhante para sujeitos em deslocamento ou recémchegados em terra de exílio.

Sujeitos sem-papéis ${ }^{62}$, mas sempre fornidos de calhamaços de papéis (DAVOUDIAN, 2015). A documentação que regularize a permanência, nesse contexto, parece ter uma importância considerável: é tanto o que produz reconhecimento institucional da condição vivida pelo sujeito - de tudo o que viveu para chegar até a terra de exílio, como o que garante sobrevivência e condições dignas de vida. A inscrição dos sujeitos pela obtenção de documentos, portanto, concomitantemente atesta a experiência e garante a sobrevivência. Assim, na instalação das condições necessárias para a localização subjetiva (ROSA, 2012a) que norteia a intervenção clínica nesses contextos, está presente a dimensão institucional também dos papéis e documentações.

Com o caso L., vimos diversas sessões serem permeadas pela presença física dos calhamaços de papéis, das cópias de documentos que presentificavam a problemática identitária vivida por ele. Com Obi, igualmente, o temor pela entrevista e as dificuldades em como anunciar a orientação sexual vivida com tanta culpa e com poucas insígnias de comportamento que o identificassem com o estereótipo homossexual. Em suma, injunções institucionais interpelam a clínica na medida em que são reveladoras dos modos pelos quais os sujeitos são marcados em sua chegada e permanência no novo país, assim como em relação a de que podem se servir como inscrição para seguir no projeto de deslocamento. Duplamente, trata-se daquilo pelo que o sujeito é marcado e daquilo que ele faz uso.

Língua, cultura e injunções institucionais são elementos que fazem parte do contexto em que os sujeitos em deslocamento estão imersos, e, nesse sentido, somos convocados não só a incluir essas dimensões nas reflexões e intervenções sobre os casos como elementos analíticos, como a nos posicionarmos diante de algumas delas. Criar condições para que a palavra possa emergir, para que o solicitante possa se apropriar de sua própria narrativa, e

\footnotetext{
62 Sans-papiers (sem papéis) é como são conhecidas as pessoas em situação irregular, sem documentação que legalize a permanência, na França.
} 
fazer de sua experiência fragmentada de uma memória que não cessa, a construção de uma narrativa coerente, norteiam as possibilidades de intervenção nesse campo.

Então, novamente, pensamos aqui em uma intervenção do atravessamento de fronteiras, nesse caso preciso, do jurídico institucional, dos papéis, mas também entre línguas e culturas, em que o analista-coiote possa criar condições, através do encontro, de trânsito e circulação do sujeito com seus próprios recursos e em direção ao próprio desejo. Diante dos mecanismos de elegibilidade regidos pela lógica da suspeição, a escuta analítica adquire um posicionamento privilegiado.

Reformulemos essa questão diferentemente: por que falar de um analista em sua função coiote nesse contexto? Diante da arbitrariedade de uma lei que pretende regular quem tem ou não direito de se deslocar e de se instalar, posicionar a escuta em settings que se convertam em delegacias policiais, tribunais ou dispositivos de controle humanitário não nos parece uma saída possível. Aqui pretendemos retomar a origem pestilenta da psicanálise, seu caráter clandestino e também irreverente. Nesse sentido, nossa posição, muito além da obediência às leis, é a que responde a uma ética, trata-se da ética "do insconsciente, que abarca a potência do desejo que faz valer o saber criativo" (ROSA \& DOMINGOS, 2010, p.6).

Assim, circundando elementos da posição analítica e suas adjacências, no mesmo movimento, também sublinhamos a tomada de posição empreendida, essa que diz precisamente da dimensão em que não compactuamos nem com as políticas de muro, de indiferença e a necropolítica, e tampouco com a jurisprudência internacional que regula o deslocamento e a livre-circulação. Através da sustentação do posicionamento, tal qual um pilar, respondemos a uma ética das possibilidades do desejo, do livre trânsito e deslocamento pelo globo, das formas criativas de desterritorialização e da possibilidade irrestrita de circulação e instalação em qualquer parte. 
Parte III

Os mensageiros das más notícias 


\section{Capítulo 5}

\section{O analista descobridor do próprio íntimo}

Contemporâneo é aquele que mantém fixo o olhar no seu tempo para nele perceber não as luzes, mas o escuro.

(Giorgio Agambem)

Mensageiros das más notícias é como Bertold Brecht se referiu aos refugiados, desde seu próprio exílio nos Estados Unidos. Sobre essa definição, Hannah Arendt (1968), também exilada, sublinhou a potência contida na ilustração. De quais más notícias são esses mensageiros os portadores, podemos nos perguntar. Para Arendt, não se tratava dos infortúnios individuais que levavam um refugiado a se deslocar de país para país, mas a grande miséria de todo o mundo. Sobre os refugiados, a filósofa se pergunta: "se a maioria tendia a esquecer sua mensagem, antes mesmo de perceber que ninguém gosta do portador de más notícias - bem, não foi sempre esse o problema com os mensageiros?” (p. 321). Mensageiras dos infortúnios do mundo, as populações mais pobres exiladas portam com suas presenças o indesejável que repousa no íntimo de cada um. Nesse sentido, podemos nos perguntar, qual mensagem? O que eles trazem? Quais as más notícias? Essas serão nossas questões norteadoras do presente capítulo.

Vimos até aqui o quanto as próprias presenças de recém-chegados anunciam (ou denunciam) a problemática dos desdobramentos da produção social dos deslocamentos atuais. Trabalhamos igualmente as migrações como modos de existência, resistência e insistência de sujeitos diante dos discursos e dispositivos de exploração, exclusão e aniquilação das populações mais pobres e vulneráveis ao redor do mundo. Nesse sentido, como indesejáveis, migrantes e refugiados são mensageiros das más notícias da contemporaneidade repousada em nosso tempo.

Tratemos de compreender melhor esse ponto. Por contemporâneo, Agambem (2009) define a capacidade de ver o escuro nas luzes de cada tempo. Tomada de distância 
intempestiva, contemporâneo é aquele capaz de, tanto dissociar do próprio tempo, quanto enxergar as trevas contidas na luminosidade de cada momento histórico. Ver o escuro, nesse sentido, não é uma forma passiva ou inerte de ausência de luz, mas uma atividade potente de ver além das luzes de cada época, para então descobrir seu escuro inseparável (AGAMBEM, 2009).

Desse modo, é partindo dessas duas noções que disparamos nossa reflexão. Mensageiros das más notícias, os migrantes da atualidade vêm interpelar a clínica, mas também nosso tempo, apontando o obscuro que repousa na luminosidade de nós mesmos. Dessa discussão, pensaremos igualmente nos posicionamentos do analista a partir do encontro com esses sujeitos. Aqui tomaremos o significante descobrimento para pensar no encontro com o outro.

Descobrir como ação intransitiva é uma investigação sobre o imenso assunto das descobertas que o eu faz de um outro (TODOROV, 1982). De fato, o assunto é imenso e mais ainda porque na descoberta repousa o encontro. Do encontro, também muitos destinos: a colonização, a aniquilação, a assimilação, a integração, o compartilhamento. Dois desdobramentos radicais podem ser paradigmáticos, a redução ou dissolução de um no outro, na dominação; ou, então, a possibilidade de que um e outro se encontrem em uma alteridade que, concomitantemente, possa afirmar a exterioridade e reconhecer a humanidade. Para Todorov (Ibden), a descoberta da América pelos espanhóis é cena inaugural do extremo que um encontro radical pode atingir em sua estranheza. Trata-se do encontro extremado ${ }^{63}$ que o eu faz de um outro, pois trata-se também do maior genocídio da história da humanidade.

Poderíamos cunhar rapidamente dois dos extremos da descoberta do outro como o de um encontro colonizador e de um encontro do compartilhamento. Sendo o da colonização todo aquele que, na descoberta, desconhece o outro em sua alteridade, tal como a descrição de Todorov, que podemos retomar a título de exemplo, sobre a carta de Cristóvão Colombo ao reino da Espanha, em 1492, referindo-se aos povos nativos que encontrara na América: "Se Deus assim o quiser, no momento da partida levarei seis deles a Vossas Altezas, para que aprendam a falar" (TODOROV, 1982, p. 42). Aqui fica claro que, para Colombo, não é que os indígenas falassem outras línguas e, portanto, trataria de ensiná-los o espanhol, eles

\footnotetext{
${ }^{63}$ Encontro extremado aqui não em sua compreensão de estranheza em relação à diferença, mas em relação à objetificação perpetrada pela dominação dos espanhois aos povos autoctones.
} 
simplesmente não falam, coincidência de língua e logos, vemos aí esboços de uma política de aniquilação do outro em sua humanidade.

Dos encontros de compartilhamento, podemos pensar em todas as descobertas que o eu faz também de si e de seu próprio íntimo através da exterioridade daquilo que se apresenta no encontro com o outro. É disso que iremos tratar no presente capítulo. Analista e analisando em seu encontro a partir da radicalidade dos traços encarnados na figura do estrangeiro. Encontro do próprio íntimo através da exterioridade e da alteridade representados ou suscitados pelo outro. Ou ainda, figuras do contemporâneo, pensaremos no encontro com o migrante que vem desvelar os pontos cegos de um tempo. Nesse sentido, a clínica com pessoas migrantes serve apenas de metáfora para pensar qualquer encontro com o outro, encontro que é sempre radical. Desse modo, pensamos nas vicissitudes da descoberta do outro em si, e trataremos de pensar no encontro como a possibilidade de compartilhamento.

\section{$* * *$}

Há um outro ponto a ser levado em conta antes de pensar nas possibilidades e destinos produzidos pelo encontro: as formas pelas quais, muitas vezes, o estrangeiro é tomado em sua alteridade/ipseidade e uma das funções por ele ocupadas na relação. Dois personagens, um da literatura e outro do cinema, abordam, à sua maneira, um movimento particular que gostaria de me ater a título ilustrativo. Brodeck, personagem do romance Le rapport de Brodeck de Philippe Claudel (2007), e Grace, a protagonista do filme Dogville (2003), de Lars von Trier, interpretada pela atriz Nicole Kidman. Ambos os personagens revelam um aspecto suscitado pelo encontro que chamarei aqui de efeito de denunciação.

No livro Le rapport de Brodeck, Brodeck é um personagem recém-chegado a seu vilarejo depois de ter sido deportado para um campo de concentração. Único não participante de um assassinato de um estrangeiro por todos os homens da cidade, Brodeck é encarregado pelas autoridades locais de escrever um relatório sobre o acontecimento. Por sua estrangeiridade, Brodeck, através do relatório e de seus desenhos sobre os habitantes da cidade, reenvia quase que pelo reflexo de sua mirada a imagem daquilo que os outros não querem saber sobre si, e que estavam encarnados na figura estrangeira assassinada. Figura essa chamada de: 
Mondlich - lunático 'pelo seu ar de estar em nosso lar sem estar verdadeiramente'; ou então 'Gekamdorhin' - 'Este que é vindo de lá'. Mas para Brodeck era simplesmente 'De Anderer' - o Outro - porque além de chegar de lugar nenhum, tinha a impressão de que 'ele é um pouco eu' (Nouchi, 2007).

Já Dogville é uma cidade pobre “onde a estrada chega ao seu final”, de poucos habitantes, e que recebe Grace, a filha de um gângster que não aprova a vida de seu pai e se refugia no local. Recém-chegada, Grace é acolhida por Tom, um jovem rapaz que intercede coletivamente em favor dela, porém os outros habitantes só aceitam escondê-la em troca de pequenos serviços prestados. A partir daí, a trama se estabelece e a presença de Grace passa a reinterrogar a sociabilidade até então instaurada em uma comunidade que se revela como tendo sido fundada através de uma série de não-ditos.

Tanto o livro quanto o filme, cada qual com sua problemática, evidenciam o movimento de chegada de um estrangeiro em espaços de funcionamento endogâmicos e que fazem de sua presença objeto de repulsa, na medida em que a sua estrangeiridade denuncia o funcionamento próprio à comunidade. Espelho invertido, ou ainda, espelho em negativo, a presença do estrangeiro - pelo seu olhar de estrangeiridade - produz efeito de denunciação do modo de funcionamento local. É no reflexo do olhar do estrangeiro, que se revela aquilo que não se quer ver. Nesse sentido, no movimento próprio da alteridade, estrangeiridade é elemento revelador do funcionamento recalcado. Não à toa, vemos aí a confluência etimológica trabalhada por Derrida, entre hospes e hostis da palavra hospitalidade, condensada na figura do estrangeiro.

Efeito de denunciação é, portanto, aquilo que a exterioridade encarnada na figura de um outro suscita ou evidencia de latente em si. Trata-se, portanto, de uma reatualização, na relação, do próprio íntimo recalcado, mas agora exteriorizado nos traços de estrangeiridade do outro. Como reatualização ou repetição, o efeito de denunciação é todo aquele que enuncia a presença de uma representação recalcada. Efeito de espelho de uma imagem em seu negativo, é nisso que consiste o efeito de denunciação da chegada de um estrangeiro em determinados contextos. Efeito de denunciação é também um efeito de enunciação no discurso, e, portanto, de (d)enunciação.

Tendo em vista esse movimento, gostaríamos de abordar um encontro particular. Se Todorov considerou o encontro de Colombo com os indígenas na América como paradigmático de um extremo, trataremos de pensar em algumas das vicissitudes de encontros 
suscitados pelas "novas" migrações no Brasil. E, de algum modo, investigar o que essas novas presenças de pessoas oriundas de determinados contextos acabaram por interrogar da realidade brasileira. Em um primeiro momento, pensaremos nos desdobramentos do encontro entre esses novos fluxos migratórios e a população brasileira para nos atermos, enfim, às possibilidades de encontro e compartilhamento entre analista e analisando, nesse âmbito.

Tomando como disparadora a noção de efeito de (d)enunciação, partimos de uma hipótese central de que as novas migrações, com sua presença, acabaram por interrogar predominantemente dois aspectos fundamentais da realidade brasileira: a violência política e o racismo. Trataremos então de investigar, a partir da perspectiva do encontro, as formas pelas quais as novas chegadas passaram a interpelar elementos que podemos compreender como de certa forma latentes na representação da sociedade brasileira, para em um segundo momento, pensar nas possibilidades de escuta e intervenção do analista nesse contexto.

\subsection{Uma certa "descoberta" tardia do racismo e o seu efeito de (d)enunciação}

Louis era um adolescente recém-chegado ao Brasil quando começamos a nos encontrar semanalmente. Com quinze anos, ele acabara de chegar sozinho desde a República Democrática do Congo. Já em nossos primeiros encontros, Louis expressou seu estranhamento com a lógica bastante peculiar de uma geografia urbana delimitada em função da cor de pele, na cidade de São Paulo. Cidade ainda estrangeira, mas que ele, com seus olhos atentos e assustados, tratava de cartografar e compreender seus códigos. Dirigindo-se a mim, sua psicoterapeuta assignada com a cor branca no Brasil, ele pergunta, em francês: "Gostaria muito de compreender uma coisa; a polícia brasileira tem alguma coisa contra os negros? Eu não consigo entender muito bem, mas todas as vezes que saio nas ruas [próximo ao abrigo onde morava], principalmente à noite, ou com outros amigos negros como eu, a polícia nos para sistematicamente. Não entendo isso. Os outros adolescentes me disseram que quando começa a anoitecer, não posso usar nada na cabeça, nem boné, e nem o capuz do casaco, mesmo se estiver frio, disseram que é perigoso e que posso tomar um tiro, e também tenho sempre que estar com documentos, mas tenho só esse papel amassado”.

Espelho em negativo, a denúncia do racismo emerge de um olhar não familiar que Louis porta sobre o funcionamento institucional nos espaços públicos brasileiros. Ao mesmo 
tempo, ele parece também comunicar algo que é presente em nossa relação: a diferença de cor e nossos distintos lugares de assignação em um mesmo espaço social.

A pergunta, à primeira vista ingênua, de Louis sobre a abordagem policial sofrida sistematicamente nas ruas de São Paulo é impactante, e revela, a uma só vez, a lógica de um racismo institucionalizado presente na geografia urbana das cidades brasileiras, e também seus impactos nos modos de circulação e subjetivação em um laço social deformado pelas marcas da violência do racismo. Vemos repetidamente que, somado às experiências extremas de violência vividas nos países de origem e nos deslocamentos, o encontro com novas modalidades sociais de racismo na chegada ao Brasil vem marcar a relação de alguns dos migrantes recém-chegados e o novo país.

Martin também havia chegado há poucos dias quando nos vimos pela primeira vez. Nessa ocasião, estava assustado, tinha a voz hesitante, não sabia bem a quem podia dizer o quê, ou em quem confiar. Disse que não conseguir dormir, parecia desamparado e encontrar um adulto que falasse francês parecia também ser um grande alívio. Martin tinha 17 anos, era recém-saído do último ano de estudos escolares e vinha também de Kinshasa. Logo contou que quando desembarcou no aeroporto de Guarulhos não sabia em que país estava: pensava que fosse talvez Estados Unidos, Canadá ou algum país da Europa. Estava sozinho, e em São Paulo, logo na chegada, foi encaminhado para um serviço de assistência, e quando acionado o Conselho Tutelar, Martin foi abrigado em uma instituição para crianças e adolescentes.

Ainda em nosso primeiro encontro, contou-me sua história mais recente, essa que havia incidido como acontecimento implacável no curso de sua vida, até seus 17 anos. Filho de um importante advogado congolês, vivia uma vida confortável com seus pais e uma irmã de 12 anos. Martin escrevia poesias, falava cinco línguas, gostava de literatura, estudava latim, e dizia que, embora seu pai sempre tivesse desejado que ele se tornasse também advogado, ainda não sabia qual seria sua profissão. Contou-me que seu pai era um homem livre, crítico e independente, que há alguns meses havia realizado um importante relatório denunciando os crimes do governo de Joseph Kabila e sua tentativa de permanecer em um terceiro mandato, e a denúncia havia sido veiculada em rede nacional. Dias depois, ligações anônimas em plena madrugada, ameaças chegavam de vários lados.

Em uma noite durante a semana, quando Martin estava em seu quarto, ouviu a porta de casa ser invadida por militares. Pai, mãe e irmã estavam na sala e foram imediatamente rendidos. Do quarto, ouviu seu pai gritar na língua de sua etnia - língua materna de Martin e 
que não era inteligível pelos perseguidores - para que fugisse pelos fundos, rápido, sem hesitar, e que procurasse um de seus amigos para auxiliá-lo na fuga. Foi quando Martin escapou da casa e correu sem olhar para trás, correu quilômetros, até chegar a um bairro distante, e, de lá, amigos do pai rapidamente o levaram para o sul do país. Já distante de Kinshasa, aquele a quem chamava de tio designou um homem que passou a se ocupar de Martin durante algumas semanas. Com esse homem desconhecido, e sempre misterioso, chegaram na Zâmbia, e, de lá, sem nenhuma informação, embarcaram em um avião, que depois de algumas escalas e só na chegada, Martin veio a saber que tinha como destino o Brasil. Minutos depois do desembarque, o homem desapareceu e ele nunca mais voltou a vêlo.

Depois de algum tempo no Brasil, Martin passou a denunciar suas primeiras vivências de racismo no novo país. No abrigo em que estava instalado, outros adolescentes lhe proferiam constantemente xingamentos e agressões racistas que beiravam, frequentemente, à ameaça de uma agressão física. É quando, profundamente chocado, Martin diz, em sessão: “Não entendo, eles [os outros adolescentes] são negros também, talvez eles tenham a pele um pouco mais clara que a minha, mas eles também são negros. Será que eles se sentem superiores a mim, por isso?". Pela primeira vez, Martin parecia viver uma experiência de segregação no laço em um contexto com pessoas da mesma idade e passando por uma situação semelhante.

No contexto brasileiro, racismo é uma experiência de violência presente no processo de subjetivação desde a mais tenra infância. A interiorização, desde muito cedo, das lógicas institucionais e estruturais do racismo compõe o cerne das modalidades de Ideal de Eu para os sujeitos negros e brancos imersos nessa realidade social. É do cruzamento entre a pequena e a grande história de cada sujeito que podemos pensar na incidência do traumático da violência racista presente na sociedade.

A partir dos trabalhos da psicanalista Neusa Santos Souza (1983), vimos como a subjetividade atravessada pela lógica racista no Brasil é aquela cujo Ideal de Eu é predominantemente branco. Segundo ela, os sentimentos de: "culpa e inferioridade, insegurança e angústia atormentam aqueles cujo ego caiu em desgraça diante do superego. A distância entre o ideal e o possível cria um fosso vivido com efeito de autodesvalorização, timidez, retraimento e ansiedade fóbica" (SOUZA, 1983, pag. 41). Fosso esse entre o corpo 
negro marcado pelas práticas de violência institucionalizadas e o ideal social com caráter superegóico de um corpo branco.

Se parte dos sujeitos negros e brancos brasileiros parecem haver interiorizado as modalidades de violência do racismo institucional desde seu primeiro processo de subjetivação no laço, para os sujeitos negros africanos ou vindos de outros países, a realidade parece ser um pouco distinta. Através do choque e estranhamento vividos pela primeira vez em função de determinadas práticas racistas, vemos emergir a denúncia de um funcionamento bastante próprio à realidade brasileira. $\mathrm{O}$ confronto já mais tardio de práticas de racismo institucionalizadas e muitas vezes naturalizadas produz efeito de denunciação dos modos de distorção do laço em um mesmo espaço social. Dupla injunção de violência, portanto, trata-se de um processo vivido nos primórdios da formação do eu, e com efeitos deletérios e perenes na subjetividade marcada pelo racismo. Esse mecanismo marca o processo de subjetivação do sujeito negro e do sujeito branco brasileiro.

Uma "modalidade de angústia disparada pelo enigma da desigualdade social", tal é a proposição do psicanalista Gonçalves Filho (1998) sobre o conceito de humilhação social, afeto de determinações econômicas e inconscientes. É possível pensar, assim, na humilhação social como os efeitos de um modo de subjetivação marcado pela deformação do laço em decorrência da acumulação de capital; trata-se de um fenômeno tanto psicológico quanto político (GONÇALVEZ FILHO, 1998), portanto. As formas pelas quais a subjetividade forjada nesse laço se apresenta não são as mesmas em pessoas oriundas de outros contextos sociais, também racistas e desiguais, mas atravessados por outras modalidades institucionais.

Podemos pensar ainda em um outro fragmento clínico, desta vez em Laurinda, também recém-chegada da República Democrática do Congo, fugida com sua filha pequena de uma situação de violência doméstica de seu marido. Os primeiros meses de Laurinda e Aleluia no Brasil foram meses atribulados em função da constante ameaça de perseguição do marido e de que pudessem ser descobertas no novo país de refúgio. Laurinda era enfermeira em seu país, tinha um bom trabalho e ansiava por uma vida profissional em desenvolvimento. Depois da gravidez de Aleluia, a situação de violência em sua casa começou a se degradar, os episódios foram ficando cada vez piores, até que Laurinda decidiu fugir de casa, e com a ajuda de irmãos, veio para o Brasil.

Em São Paulo, depois de um tempo, Laurinda foi adquirindo mais segurança, se fortalecendo na decisão de reconstruir uma nova vida ao lado da filha no Brasil e se 
permitindo constituir novos laços e circular na cidade. Igualmente, as marcas que portava dos repetidos episódios de violência de seu marido começavam a cicatrizar em seu corpo. Nesse movimento, Laurinda arrumou um trabalho em um restaurante e matriculou Aleluia, de 5 anos, na escola. A vida começava a andar, aos poucos, e nos primeiros encontros, um choque. Ainda nas primeiras semanas de adaptação, Laurinda relata assustada, em sessão, que Aleluia chegava diariamente em casa chorando por ter ouvido de outras crianças que ela era feia. Laurinda estava indignada, e com raiva dizia: "que história é essa de minha filha ser feia? Ela é uma criança linda, sempre foi vista como linda, e eu sempre disse isso a ela, é inacreditável ela ouvir essas coisas na escola, já conversei com as professoras, isso é inaceitável. Não entendo o Brasil. O que é isso? Outro dia, eu estava no ônibus, indo para o trabalho, vi um lugar vago e assim que me sentei a senhora que estava ao lado se levantou fazendo uma cara feia e dizendo coisas. É muito revoltante isso que se passa aqui nesse país".

A chegada e a presença de novas populações negras para o Brasil trazem, nesse sentido, uma problemática que merece aqui duas considerações sobre a relação intersubjetiva entre migrantes recém-chegados e brasileiros instalados: a de uma certa "descoberta" de novas modalidades de racismos pela população estrangeira; e o efeito de denunciação do racismo estrutural brasileiro trazido pelas novas chegadas, que trataremos mais adiante.

Sobre a "descoberta tardia" feita pelos migrantes negros recém-chegados, sublinhamos as aspas, pois trata-se de um falso enunciado. Racismo é uma prática hegemônica em todo o mundo, e ainda que certos países ou contextos sociais africanos não tenham exatamente as mesmas modalidades institucionais de racismo, todos os países do continente foram marcados por séculos de colonização europeia, portanto conhecem o racismo enquanto ideologia e prática de violência; no entanto, a chegada em um novo contexto faz emergir, pelo contato, características próprias do funcionamento brasileiro.

Assim, se de um lado, vemos o sofrimento expresso como indignação e questionamento do enigma racista - no sentido laplanchiano das mensagens enigmáticas próprias do traumático - pelos migrantes negros congoleses recém-chegados; vislumbramos igualmente o efeito de (d)enunciação dos mecanismos de violência social presentes no espaço geográfico, nos modos de circulação urbano e sua incidência na subjetividade dos sujeitos negros e brancos brasileiros que interiorizaram, desde muito cedo, essas modalidades de racismo. 
Portanto, se no encontro entre sujeitos recém-chegados das novas migrações e brasileiros vemos o efeito de um espelho em negativo das modalidades de agressão, vemos também o sofrimento em sua forma crua, fruto de uma violência de aniquilação do corpo e da existência em decorrência de um sistema econômico.

\subsection{Negritude, branquitude e violência política como analisadores na clínica}

Como abordamos na primeira parte da tese, tomamos como "novas" migrações para o Brasil o fluxo acentuado de populações de países da África, da América Central e do Oriente Médio nos últimos anos. A trajetória de deslocamentos de pessoas oriundas dessas regiões é marcada por dois eixos de significação que são transversais e incidem de forma confluente na representação sobre o migrante atualmente: o contexto social nos países de origem e a representação imaginária hegemônica pela qual seus corpos e presenças são tomados no mundo contemporâneo. Isto é, trata-se de regiões do globo mais atingidas por contextos de extrema violência política e, simultaneamente, populações representadas como indesejadas pelo discurso hegemônico de valorização da cultura ocidental e do ideal do corpo branco.

Guerras civis, invasões estrangeiras, ditaduras militares, perseguições políticas de diversas naturezas, catástrofes naturais que agudizaram as estruturas sociais, as profundas precariedades sociais e o fechamento das fronteiras ocidentais são elementos centrais na reprodução social dos deslocamentos contemporâneos e das rotas Sul-Sul. Violência política é, como vimos, um fenômeno central nas trajetórias que impulsionam deslocamentos massivos pelo globo. E, num outro eixo, sobre a representação hegemônica dessas populações como indesejáveis, diversos são os elementos que poderíamos tomar como analisadores, tais como religião ou pertencimento cultural, mas, com exceção dos migrantes sírios ou de outros países do Oriente Médio, Ásia Menor ou Maghreb, as populações de recém-chegados da América Central e países da África são marcadas pelo que o antropólogo Kabengele Munanga (JAIME \& LIMA, 2013) chamou de a geografia do corpo negro e sua representação nos países racistas.

Nesse sentido, nos interessa pensar sobre o encontro produzido entre as populações de recém-chegados das "novas" migrações e a população brasileira para refletir sobre as possibilidades de intervenção clínica entre analista instalado no país e analisando recémchegado - intervenção que proporcione o diálogo, a escuta do sofrimento e a emersão dos 
conflitos latentes na relação, e não a invisibilização, o desmentido ou a despolitização. Antes de tudo, devemos partir da constatação de que as novas rotas Sul-Sul e o fluxo de chegadas para o Brasil estabeleceram uma nova relação entre pessoas oriundas de países outrora colonizados pela Europa e a população de um país também colonizado historicamente. Por isso, não se trata de um encontro fortuito, e partimos da complexidade do confronto entre duas populações marcadas pela colonização em diferentes tempos e de diferentes formas para investigar as possibilidades de intervenção clínica. É da presença do colonial como elemento histórico presente nos dois contextos que partimos, portanto, em nossa reflexão.

Para isso, ainda duas considerações sobre a realidade brasileira se fazem necessárias antes de explorarmos a hipótese de que essas novas chegadas culminaram por interpelar elementos estruturantes que permanecem latentes, são elas: racismo e violência política. Isto é, trata-se de compreender o lugar do sujeito negro e do sujeito branco na sociedade brasileira, o racismo como elemento estrutural das relações sociais e a violência política como marca transgeracional na história do país.

Juntamente com Marie-Caroline Saglio-Yatmirisky (SAGLIO-YATZIMIRSKY \& GEBRIM, 2017), lembramos que o regime de escravidão foi abolido no Brasil somente em 1888 , isto é, trata-se do último país do continente americano a ter interditado essa prática. Durante trezentos anos, a população africana foi sujeitada a um deslocamento forçado também para o Brasil que marcou de forma indelével sua diáspora. Depois da Nigéria, o Brasil é o segundo país do mundo em importância numérica de sua população negra. Ainda que majoritários, trata-se de uma população profundamente marcada pela exclusão social e racismo, como revelam as estatísticas sobre as desigualdades e violências. Os traços históricos de uma política de dominação social legitimando submissão, exploração e desigualdade com a população negra atravessam o Brasil contemporâneo. Ao mesmo tempo em que os migrantes negros recém-chegados reatualizam as antigas formas de discriminação pela cor da pele, eles também denunciam as formas do racismo brasileiro contemporâneo. A nova presença negra em território brasileiro faz ressurgir à superfície todo um sistema de representação que parecia estar encoberto (SAGLIO-YATZIMIRSKY \& GEBRIM, 2017).

Concomitante à certa "descoberta" tardia de determinadas modalidades de racismo pela população migrante recém-chegada, também vimos o aumento de manifestações racistas no país, e em particular na cidade de São Paulo, cidade que mais recebeu migrantes. De acordo com dados oficiais, as queixas de atos de xenofobia aumentaram de forma exorbitante 
em pouco tempo. De 2014 a 2015, em um ano, a quantidade de queixas prestadas aumentou 633\% (MACIEL, 2016). Com a chegada dos novos fluxos, assistimos, portanto, a diversas manifestações e atos criminosos de xenofobia e racismo em várias cidades do país.

Se a geografia do corpo negro é lugar de endereçamento da violência racista, a geografia da cidade também reproduz a mesma dinâmica do ódio espacializado. Se, como vimos, para uma parte da população africana e haitiana recém-chegada, o racismo institucionalizado nos espaços urbanos é uma "descoberta" tardia, eles mesmo se veem igualmente confrontados, assim, com as representações brasileiras de negritude. Dessa forma, esse encontro do negro estrangeiro, o radicalmente negro, com a população brasileira não cessa de enunciar as diversas práticas sociais forjadas nos não-ditos da violência histórica do Brasil (SAGLIO-YATZIMIRSKY \& GEBRIM, 2017).

Com Darcy Ribeiro (1995), entendemos que o processo de formação do Brasil foi marcado por diferentes movimentos de embranquecimento da população, e que, ainda que em relação à colonização hispânica, o domínio português tenha sido substancialmente atravessado pela miscigenação, o racismo brasileiro é de natureza assimilacionista porque em distintos momentos históricos sempre estimulou o embranquecimento da população. Trata-se de uma situação em que mestiçagem sempre foi estimulada enquanto fator de embranquecimento da pele. A perspectiva do racismo assimilacionista implica em compreender que as formas de expressão do racismo não são ligadas necessariamente às origens étnicas ou raciais da população, e sim em função da cor de pele. Nessa dinâmica, branquitude passa a ser uma condição adquirida, tanto através da miscigenação, quanto através da incorporação de signos raciais brancos e da ascensão social.

Nesse sentido, segundo Carone (2002), a ideologia do branqueamento foi elemento forjado pelas elites brancas do século XIX e inícios do XX e culminou em distintos processos, tal como o estímulo às políticas imigrantistas que favoreceram de forma expressiva a vinda de migrantes europeus em detrimento de outros continentes de populações não brancas. Sobre a ideologia do branqueamento na formação do Estado brasileiro e seu imaginário social:

Se nos períodos pré e pós-abolicionistas ela parecia corresponder às necessidades, anseios, preocupações e medos das elites brancas, hoje ganhou outras conotações - é um tipo de discurso que atribui aos negros o desejo de branquear ou de alcançar privilégios da branquitude por inveja, imitação e falta de identidade étnica positiva. O principal elemento conotativo dessas representações dos negros construídas pelos brancos é o de que o branqueamento é uma doença ou patologia peculiar a eles (CARONE, p.17). 
Assim, é possível compreender o processo histórico de embranquecimento da população tanto como uma política promovida pelo Estado, como, em um segundo momento, uma condição desejada a ser adquirida em detrimento da valorização do corpo negro, mas atribuída a uma patologia própria do negro. Com Mussatti-Braga (2015), vemos as pistas da complexidade de um racismo estrutural brasileiro:

a expectativa de que os negros desaparecessem numericamente e fossem
assimilados pelos brancos, com seus descendentes cada vez mais claros,
como modo de melhoria racial ou processo civilizatório - e o incentivo para
que isso ocorresse - nos parece um dos elementos chave na sensação de
invisibilidade. Como dissemos, se num primeiro momento tratava-se da
promoção desse branqueamento concretamente promovido como política de
Estado, num segundo momento o branqueamento passa a ser interpretado
como um desejo do povo negro que, supostamente, negaria e desvalorizaria
suas próprias origens, buscando alcançar a branquitude (p.63).

Partindo dessas noções sobre o racismo estrutural presente na formação histórica brasileira e os processos de branqueamento da população e a forma como isso foi interpretado pelo discurso branco sobre o negro, podemos pensar que a nova presença negra em território brasileiro traz à tona o signo sob o qual tentou-se apagar. É possível conjecturar que na mesma medida em que as novas chegadas de populações migrantes negras reatualizam as formas de discriminação através da percepção da cor de pele, em contrapartida, são essas mesmas comunidades que denunciam as formas de expressão do racismo brasileiro. Se, como vimos, o segundo momento do processo de branqueamento se refere à interpretação deformada do discurso branco de que o sujeito negro é o que deseja se embranquecer negando a si mesmo e ao seu próprio corpo, as novas presenças negras migrantes vêm interrogar precisamente esse aspecto em relação à branquitude. Isto é, a negritude como elemento que vem interrogar a branquitude.

Segundo a psicanalista Jo Gondar (2017), o racismo brasileiro opera na ordem do desmentido, no sentido ferencziano do termo. Trata-se, portanto, de um mecanismo de violência social próprio da clivagem, e não do recalque. Segundo ela, o Brasil afetivo e cordial, o mesmo do mito da democracia racial, convive, tal qual uma cisão, com a realidade de segregação presente em todo espaço público. Clivagem é, assim, o modo brasileiro de lidar com o passado (GONDAR, 2017), fazendo conviver em um mesmo projeto social duas 
realidades cindidas. Isto é, o projeto da branquitude de embranquecimento da população e hierarquia do corpo branco convive com o elogio da mestiçagem.

Branquitude, nesse sentido, não é espelho simétrico de negritude (GONDAR, 2017), ou uma simples contraposição em relação a diferentes cores de pele, mas sobretudo um modo de subjetivação calcado na hierarquia e correspondente à desvalorização do ser negro. Racismo é, portanto, um fenômeno desmentido na representação hegemônica brasileira, e como em todo desmentido, segundo Jo Gondar, é o sujeito quem sofre um desmentido, pois ao duvidar do que viveu, passa a duvidar de si mesmo, o aniquilamento subjetivo próprio do traumático não provém somente da violência infligida, mas também de seu desmentido. Sendo assim, podemos pensar que as novas presenças vêm interpelar e enunciar o desmentido da realidade do racismo brasileiro e da violência estrutural constitutiva da realidade social.

$\mathrm{O}$ segundo elemento fundante que penso ser interrogado pela chegada dessas novas migrações é o da violência política no contexto brasileiro. Com mais de 322 anos de colonização, a história do Brasil é marcada por largos processos de genocídio indígena, escravização de populações, proibições linguísticas e apagamentos culturais durante séculos. A história recente do país foi brutalmente atravessada por uma ditadura militar de vinte anos, cuja estratégia política era a tortura, o desaparecimento de pessoas, o massacre de determinadas populações e a censura. Nenhum crime cometido pelo governo militar e seus agentes do Estado foi julgado (diferentemente de alguns países vizinhos, como a Argentina e o Chile), vários dos perpetradores que ainda estão vivos seguem ativamente na vida pública e política do país, e tortura e desaparecimento seguem sendo estratégias cotidianas de uma polícia brasileira ainda militar.

Atualmente, junto ao cenário de violência urbana nas grandes cidades, soma-se o fenômeno da violência policial, com índices altíssimos de homicídio. E, cabe ressaltar, em cada 10 pessoas mortas pela polícia, 9 são negras (GALLI, 2017), dados que têm levado os movimentos sociais a falarem de um genocídio da população negra e pobre no Brasil. Segundo a psicanalista Maria Rita Kehl (2013), por analogia, esse fenômeno pode ser compreendido como uma repetição sintomática da violência traumática dos crimes da colonização e da ditadura militar que nunca foram julgados ou reparados:

O apagamento rápido (e forçado) dos crimes da ditadura lembra os efeitos perversos do esquecimento dos crimes da escravidão (...). Não é absurdo pensar que o Brasil, país do esquecimento fácil, do perdão concedido antes 
por covardia e complacência do que por efeito de rigorosas negociações, seja um país incapaz de superar sua violência social originária. Os sintomas da brutalidade consentida ressurgem nas execuções policiais que vitimam jovens nas periferias de São Paulo, nas favelas do Rio e em todas as outras grandes cidades brasileiras (s.p.).

As novas chegadas de populações migrantes oriundas de países africanos em conflito passaram a interpelar, portanto, esses dois elementos da sociedade brasileira. É possível conjecturar que ambos, o racismo e a violência de Estado, têm caráter paradoxal, isto é, são reveladores da sociedade tal qual ela se representa, mas permanecem fora da representação na medida em que não são reconhecidos institucionalmente. De um lado, o mito da democracia racial segue operando como discurso hegemônico, e de outro, a impunidade e o esquecimento dos crimes da colonização, da escravidão e da ditadura militar. Ambos convivem com a realidade social marcada pela violência política e pela segregação racial.

Militantes políticos congoleses vítimas de perseguição do governo de Joseph Kabila, famílias nigerianas fugidas do Boko Haram, manifestantes encarcerados em Angola, familiares de desaparecidos no Camarões, crianças que foram sequestradas e viveram anos como soldados em Serra Leoa, vemos nas diferentes realidades das trajetórias de migração desses recém-chegados elementos que encontram ancoragem nas formas pelas quais o Brasil não se reconhece. Efeito de (d)enunciação, portanto, são as novas presenças que, em busca de inscrever o acontecimento traumático, desvelam o buraco de significação próprio da realidade brasileira em que cada sujeito é constituído.

\subsection{O inconsciente colonial como o transtraumático: um lugar possível?}

É a guerra dentro da análise, sem metáfora

(Davoine e Gaudillière)

A partir dessa discussão, podemos disparar finalmente algumas questões centrais em torno da posição do analista nesse contexto. Questões que, de antemão, partem de duas dimensões para problematizar a intervenção clínica: a de pensar, por um lado, nas possibilidades de endereçamento, fiabilidade e constituição de laço de um sujeito estilhaçado pelo extremo de uma vivencia traumática para um analista, e por outro, quais as condições de 
sustentação, para o analista, de um lugar passível de escuta de um sujeito imerso em seu próprio extremo. Duas dimensões que dizem, a uma só vez, do encontro analítico entre dois.

Sobre as vicissitudes do traumático e o estilhaçamento do sujeito pela experiência tratamos mais longamente no capítulo 3. Interessa-nos agora, nesse segundo momento, pensar, desde o lugar do analista, as possibilidades de sustentação e fiabilidade de sua escuta e intervenção. Essa inquietação parte sobretudo de minha própria implicação com o tema, isto é, de uma problematização sobre minhas intervenções e sobre a procura permanente de conseguir sustentar um lugar possível de escuta analítica. Da busca incessante de uma boa distância, entre o nem tão longe e nem perto demais, para que o trabalho com o sofrimento extremo possa ser concebido a longo prazo na clínica. Tenho constatado, em diversos meios, que muitos colegas iniciam suas vidas profissionais trabalhando nos contextos limite, nos trabalhos de "ponta", como são frequentemente chamados, para saírem após alguns anos, muitos deles, exauridos, estilhaçados por uma escuta hiper-implicada e que termina por adoecer profundamente seus próprios extremos.

A inquietação parte também de um pequeno mote: meus sonhos de guerra. Durante o período mais intenso de atendimentos com migrantes em situação de refúgio, era frequente a sensação de que parte de mim passava também a viver em guerra. Havia momentos em que a cada novo encontro com um paciente, o front era reatualizado em minha sala, e meu corpo emprestado para a cena de batalha. À noite, no interior seguro de minha própria casa, acendiase o campo de batalha no meu mundo onírico. Estive muitas vezes em destruições massivas na Síria, estive fugindo de grupos terroristas em países da África e do Oriente Médio, presa em cativeiros, perseguida nas condições mais atrozes, também torturada, e colecionei ao longo do tempo uma lista extensa deles. Passei a ter sonhos constantes de guerra.

Nunca estive numa guerra. Nasci três anos depois do fim de uma ditadura militar que marcou profundamente parte da minha família, como também todas as famílias de minha geração, e das anteriores. Sabemos igualmente que esse não foi, nem antes e nem depois, o único evento mais próximo do contexto de violência de uma guerra pelo qual somos atravessados no Brasil. Mas é a partir desse fio que gostaria de disparar a discussão. Isto é, para além de minha identificação com as cenas relatadas por alguns pacientes, o que esses sonhos de guerra diziam das minhas próprias guerras? E mais, até que ponto ter mais notícias das minhas próprias guerras cria condições de escuta para o sofrimento das guerras? 
Se $o$ front se reatualiza na proximidade da transferência (DAVOINE \& GAUDILLIÈRE, 2006), trata-se aqui, portanto, de uma tentativa de poder nomear primeiramente minhas histórias de guerras, para então criar condições de uma escuta sobre o enlouquecimento das guerras - isto é, de sujeitos enlouquecidos pelas guerras, e dessa vez, guerras vividas na carne, por eles mesmos. Nesse sentido, gostaria de propor algumas reflexões em torno da posição do analista. Para isso, partirei novamente do pressuposto de que a dimensão de cruzamento entre a grande história e a pequena história, própria da vivência do traumático, é também fator operante na singularidade do analista, e assim, pode ser tomada como posição de sustentação do trabalho analítico.

Como criar condições de endereçamento e fiabilidade para uma intervenção que vise restituir o laço? Sobre o trauma, nesse mesmo sentido, Françoise Davoine e Jean-Max Gaudillière (2006), nos colocam a seguinte pergunta: “Quando são destruídas todas as garantias da palavra, como então construir um outro a quem se pode falar?” (p.92).

Se o trabalho com o trauma é operado justamente na ordem do reconhecimento, como podemos pensar em uma inscrição simbólica possível sem reconhecer a incidência do traumático que constitui o próprio interlocutor? Como realizar uma intervenção clínica com refugiados recém-chegados de outros contextos sem levar em conta a realidade de violência presente no Brasil? Ou, ainda na dinâmica da transferência, como pensar na possibilidade de instaurar um endereçamento sem que o destinatário (analista) não esteja devidamente apropriado de sua singularidade traumática?

Por singularidade traumática podemos compreender precisamente o que já tanto dissemos até aqui do cruzamento entre a grande e a pequena história, próprio da constituição do sujeito. Assim, o trabalho analítico operado na dimensão do reconhecimento do outro só pode se dar na medida em que o analista, ele próprio, puder se implicar em seu próprio traumático. Não há reconhecimento possível do outro que não passe por um reconhecimento de si. A noção de desmentido de Ferenczi nos convoca a pensar sobre os efeitos de uma escuta que não reconhece sua própria implicação traumática em uma intervenção clínica.

Desmentido para Ferenczi, como vimos mais acima, é a operação de não reconhecimento da realidade do trauma e que produz efeitos traumatizantes para o sujeito. Trata-se, a exemplo do psicanalista húngaro, de um adulto que, ao ouvir uma criança vítima de um abuso relatar o acontecimento, diz que nada aconteceu, ou ainda sugere que a criança tenha imaginado o ocorrido. Ação que coloca em dúvida a própria existência daquele que a 
experenciou (KNOBLOCH, 1998). Posição também passível de um analista que, incapaz de reconhecer a verdade no discurso de um sujeito sobre o acontecimento, produz efeitos de denegação da vivência.

Tomamos de empréstimo essa conceitualização ferencziana para pensar nos efeitos de desmentido de um analista não implicado em sua própria história de guerra. Trataremos desse ponto mais a frente para pensar a minha posição de analista diante de alguns pacientes nesse contexto. Mas partimos da ideia de que não reconhecer sua própria implicação traumática produz efeitos de desmentido para o sujeito traumatizado. Duas considerações: de um lado, posso tomar a dinâmica da transferência tal qual um jogo de luz - me empresto à dinâmica da transferência, e com isso, ganham relevo justamente os elementos que são do outro; no entanto, esse empréstimo me implica a mim, pois é também meu corpo em cena. Mais que isso, é através do meu corpo que posso me emprestar a ser outro corpo, é através do meu próprio corpo que posso me emprestar a ser outra, em vias de restituir e inscrever junto a esse outro uma experiência inscrita no registro indizível do acontecimento-extremo. O que me interessa pensar nesse ponto é a parte em que da minha posição clínica, pela transferência, meu corpo é assim tomado em um mais além da transferência. Que, com Ferenczi, podemos chamar de contra-transferência.

Se a dinâmica da transferência pode ser compreendida como um suporte que visa restituir o laço, a palavra e a confiança na coletividade, outrora estilhaçados pelo acontecimento-extremo, nos propomos a pensar nas condições de fiabilidade desse endereçamento. $\mathrm{Ou}$, ainda, se a catástrofe traumática corresponde justamente à perda de confiança "pontual ou radical, na segurança das leis que regem os homens, o universo ou o corpo" (DAVOINE \& GAUDILLIERE, p,127) do sujeito, nos perguntamos: como restabelecer essa confiança através desse novo encontro? Em seu artigo Elasticidade da técnica analítica, Ferenczi (1928) propõe, entre outros, o tato como uma faculdade do analista de sentir com. Do tato, trata-se da capacidade genuína do analista de, empaticamente, sentir, sonhar e imaginar o sofrimento do paciente, sem com isso padecer das mesmas questões.

Mas aqui gostaríamos de pensar em um outro aspecto, esse que através do tato e da faculdade de sentir com de uma atitude empática que vise a restituir confiança e laço ao sujeito invoca os próprios extremos e traumáticos do analista. Nesse sentido, penso ser profícua a reflexão sobre a minha posição enquanto clínica nesse contexto. 
Se, por um lado, o traumático é caracterizado também pelo arrombamento do "por quê?”, como já vimos, (o 'por que' aqui como elemento que dá sentido ao acontecimento), tentarei abordar o “de onde?” como uma questão central. Dito de outro modo, até que ponto considerar certos elementos do lugar de onde falo pode servir de instrumento para a própria intervenção clínica?

Na possibilidade do endereçamento - próprio da dinâmica da transferência, gostaria de levar em conta as possibilidades de fiabilidade do destinatário, que, em primeira instância, passam pelo questionamento do quanto a escuta do outro remete ao traumático do analista. $\mathrm{O}$ ponto que gostaria de desenvolver é que a apreensão disso passa a ser condição central de uma intervenção que tem como sentido a restituição do político para o sujeito.

Do ponto de vista da contratransferência, não há como pensar em uma escuta do outro que não interpele diretamente a singularidade dos atravessamentos traumáticos do analista. No entanto, é justamente do reconhecimento desse lugar que é possível responder com a oferta de endereçamento de um trabalho que possa restituir o campo político de um acontecimento sem inscrição para o sujeito. Pensamos então, precisamente, sobre a oferta de endereçamento possível. Sobre esse processo, emprestamos do psicanalista Ghyslain Lévy (2012) o conceito de transtraumático. Vamos a sua definição inicial proposta pelo autor:

Como ouvir, escutar e acolher um sofrimento que vai ao encontro do extremo, e lhe dar a possibilidade não de abolição, de anulação, de anestesia, o que seria totalmente mortífero, mas de encontrar com o outro um destinatário possível de uma palavra que possa tocar alguma coisa de um Real frequentemente não dizível? Escutar esse tipo de singularidade em sua própria fixação só pode desmanchar algo desta problemática com a condição que o analista possa ele mesmo colocar em ação algo de seus próprios extremos, de seus próprios confins. Justamente de onde ele frequentou seus próprios confins. Existe aí uma dimensão do transtraumático que torna esse diálogo possível, não pela indiferença ou na confusão das experiências e dos acontecimentos, mas pela possibilidade do compartilhamento (CORIN, 2012, p.89, trad. livre).

Trabalhar com o extremo interpela os extremos do analista. Partindo da noção de transtraumático, portanto, temos mais condições para pensar desde onde se responde clinicamente em intervenções nesse contexto. Utilizando-nos dessa conceitualização, tratemos de avançar um pouco mais. Uma observação, não se trata aqui de problematizar quais analistas estariam ou não autorizados a essa escuta, senão de sustentar a importância de se tomar o atravessamento traumático do lugar em que o analista está situado como elemento 
fundamental, e, nesse sentido, daquilo que se refere tanto à sua história individual, evidentemente, como da história de seus pertencimentos.

Nesse sentido, falar em transtraumático não se refere à identificação do analista com as experiências do paciente, ou da confusão e indissociação a partir da transferência, tratamos aqui de um outro elemento: o da possibilidade de compartilhamento da dimensão traumática como ângulo de posicionamento para a escuta. Tal como o jogo de luz que comentamos acima, o ângulo geográfico em que o analista instala sua escuta promove concomitantemente um posicionamento em relação ao seu próprio extremo da dimensão traumática, criando condições de escuta para o traumático do outro.

Transtraumático, em seu prefixo trans, diz da posição específica de comunicação quase nunca verbal - e atravessamento entre o traumático do analista e traumático do paciente. É nesse sentido que podemos pensar que o não reconhecimento dos próprios extremos e confins do analista produz efeitos de desmentido, da dimensão transtraumática e, portanto, também do traumatismo do paciente. É precisamente o ponto de encontro entre analista e analisando no que tange ao traumático. É através da relação e da interpelação entre os dois sujeitos em comunicação sobre seus extremos que se estabelece uma dinâmica de transferência própria do transtraumático.

Davoine e Gaudillière (2006) ilustram através da metáfora de um espelho, o movimento de triangulação do encontro analítico:

um espelho particular se constitui assim. 'Espelho' da história, onde o cruzamento de duas trajetórias permite uma triangulação. E somente por esse meio torna-se possível retomar fatos essenciais que foram expulsos da transmissão. Sua existência passa a ser então possível, depois de ter sido anulada, somente pelo fato que um outro ateste, de fonte independente, e a partir de sua própria experiência (p.226).

Triangulação na medida em que o encontro de dois produz um terceiro através do reconhecimento da implicação dos dois sujeitos no laço social e na imbricação dos cruzamentos entre a grande e a pequena história. Assim, é desde o inconscient retranché (DAVOINE et al $(2006,4)$ do traumático do próprio analista, que se criam condições de oferta de reconhecimento e espaço de inscrição simbólica para o trauma do outro. Trata-se, portanto, para além do movimento de poder nomear o traumático em si para criar condições de nomeação para o outro, de situar a escuta no espaço transtraumático. 
Aqui, transtraumático se refere ao campo analítico, entre analista e analisando. Evidentemente, colocam-se aí questões sobre projeção, proximidade, mistura e hiperimplicação, mas gostaríamos de poder avançar na reflexão das condições de um lugar possível de escuta para o analista desidentificado com o traumático do paciente, como dissemos, mas implicado em sua escuta através da perspectiva transtraumática.

No Brasil, sou uma mulher branca, de uma classe média intelectualizada e oriunda de uma família afetada diretamente pelo trauma da violência de Estado na ditadura militar brasileira. No entanto, escolho aqui sublinhar a frase de que no Brasil sou uma mulher branca porque a posição de assignação identitária não é a mesma se estou no Brasil e se estou na França, dois países de inscrição dessa pesquisa, e lugares em que não ocupo o mesmo lugar imaginário; e por isso opto por tomar aqui a questão da cor como operador ilustrativo do que quero tratar: minhas próprias guerras.

Um fragmento clínico é revelador, ou descobridor. No início de uma sessão, Louis me diz: "Quando você for me chamar na sala de espera, te peço para você falar meu nome bem alto, ou vir me buscar mesmo, porque não consigo te reconhecer de longe quando você aparece na sala, é difícil, vocês brancos são todos iguais, têm todos a mesma cara, mas também as mesmas roupas e os mesmo cabelos, para mim não é fácil". Referindo-se a mim, Louis põe em cena meu corpo de analista, me implicando, na relação, sobre nossa diferença de cor de pele nesse contexto.

Foi no encontro clínico com solicitantes de refúgio e refugiados africanos que me descobri como sujeito racializado, foi na alteridade do encontro, portanto, que, em alguma medida que não era presente antes, me descobri branca. Efeito de (d)enunciação, pelo olhar de estrangeiridade desde o lugar de um africano negro, pude me ver como uma brasileira branca. Invisível até então, minha branquitude era, para mim, traço de normalidade, neutralidade, não de diferença.

Sobre esse tema, recorro à metáfora de Edith Piza (2002) sobre o choque da descoberta da branquitude:

bater contra uma porta de vidro aparentemente inexistente é um impacto fortíssimo e, depois do susto e da dor, a surpresa de não ter percebido o contorno do vidro, a fechadura, os gonzos de metal que mantinham a porta de vidro. Isto resume, em parte, o descobrir-se racializado (p.61). 
A descoberta da minha branquitude como traço racializado de diferença me inclui na dimensão compartilhada das vivências traumáticas de um país constituído pela violência racial. É através da possibilidade do reconhecimento de, por exemplo, minha branquitude e do lugar de privilégio das condições sociais estruturantes em que fui formada, que se criam algumas condições de escuta sobre as incidências do traumático do outro. Isto é, em alguma medida, me racializando passo a escutar de outra forma aquilo que é da ordem dos atravessamentos de representações raciais do sujeito. Trata-se, enfim, de uma escuta implicada no trauma.

Para atravessar a loucura das guerras é necessário construir um outro a quem se possa falar. Nesse sentido, como construir esse outro se ele mesmo não estiver inscrito em sua própria história de guerras? (DAVOINE \& GAUDILLIERE, 2006). Como pensar, portanto, o traumatismo a partir da transferência?

A implicação da escuta marca, então, um modo particular de distanciação, implodindo assim as noções mais tradicionais de neutralidade, e através de uma certa proximidade, marca o posicionamento político do analista frente ao trauma. Minha branquitude é, assim, história de guerra em um país marcado em suas entranhas pela violência do racismo.

É através da clínica que vemos que o acontecimento traumático torna-se experiência subjetiva na medida em que o sujeito, a partir da relação transferencial, se apropria da repetição como uma problemática que lhe coloca em questão, como vimos, e assim: “convocando algo do pulsional na relação transferencial que o sujeito poderá humanizar o acontecimento e restabelecer afeto e experiência vivida, o que é necessário para uma inscrição psíquica” (D’ELIA, 2014), e nesse sentido, podemos acrescentar, inscrição também política do acontecimento.

Assim, pensamos na distanciação como um modo particular de posicionamento de uma escuta implicada entre a proximidade e o distanciamento necessário com front em uma relação com o espaço. Ângulo do corpo entre o nem perto e nem longe demais, distanciação se refere aos modos de pensar nas implicações do analista inserido no campo de intervenção a partir do encontro. 
Na França, para além da noção de branquitude, a problemática sobre o posicionamento do analista poderia ser reformulada em função de outra questão igualmente presente: a colonização.

Isto é, nesse contexto, como tomar a dimensão histórica da colonização como elemento a ser incluído na intervenção clínica com sujeitos vindo de países outrora colonizados pela Europa? Ou ainda, dito de outra forma, como podemos pensar no lugar que o colonial ocupa em um mundo pós-colonial?

Para Achille Mbembe (2018), colonização e descolonização são duas faces de um mesmo processo. Descolonização, para o autor, é compreendida como um não-acontecimento, pois não representou nada mais senão uma transferência direta de poder aos que antes o detinham, abrindo dessa forma o caminho para o neo-colonialismo atual. Nesse sentido, como compreender os atuais grandes fluxos de pessoas senão como um fenômeno de produção social também fruto das intervenções neo-coloniais? Ou, como não pensar no elemento de denunciação aportado pelos fluxos migratórios mais recentes na Europa? Partindo dessas reflexões, podemos nos perguntar: como o clínico, situado em um país europeu, pode posicionar sua escuta diante de um sujeito de um país outrora colonizado e que segue sendo afetado pelos desdobramentos neo-coloniais dos países desenvolvidos? Como levar isso em conta? Isto é, como incluir na dinâmica da transferência esse componente que é o lugar ocupado pelo analista?

Nesse sentido, trata-se de pensar nos diferentes lugares que um analista ocupa no espaço, na história; lugares imaginários, mas não só, e, em um segundo momento, pensar os desdobramentos clínicos do reconhecimento ou da negação de sua implicação, que acarretaria algo da ordem de um desmentido. Através dessas reflexões, apostamos em uma posição analítica capaz de se apropriar de sua própria história, de seu insconscient retranché, e fazer operar, precisamente desse lugar de reconhecimento, uma intervenção clínica de restituição da confiança, do laço e do político.

Seja no Brasil através da noção de branquitude, ou na França, através da presença da colonização, trata-se de investigar o lugar dos componentes históricos estruturantes das relações sociais na subjetividade e sua incidência transtraumática. Se, como vimos, a 
subjetividade da população brasileira parece ter sido historicamente marcada por uma dupla injunção de violência desde o nascimento: a de encarnar o ideal de eu do corpo branco e o de negar o corpo negro (FREIRE COSTA, 1984); o que dizer da subjetividade do branco brasileiro? Subjetividade essa marcada historicamente - ainda que aparentemente invisível pela condição, não somente privilegiada (no que concerne às condições materiais da sociedade), mas por uma pressuposição de superioridade? Subjetividade, portanto, profundamente abalizada pela deformação do laço constituído pela violência racista.

Aimé Césaire em seu "Discurso sobre o colonialismo" discorre sobre o quanto a colonização descivilizou o próprio colonizador. Isto é, falando de uma civilização doente, Césaire revela o quanto a colonização desumanizou o colonizador, pois no movimento de desumanizar o outro, há um traço de caráter que se deforma. Podemos pensar também na formulação de Todorov (2008), segundo a qual bárbaros são justamente todos os atos que não reconhecem o outro enquanto também humano. Nesse sentido, com Césaire, pensamos que não só a colonização deformou o colonizador, como o tornou bárbaro, ainda que crente de seu lugar civilizatório.

Assim, branquitude, no contexto brasileiro, pode ser tomada como uma problemática colonial. Entre colonialismo e processos de subjetivação, nos propomos a pensar em suas ressonâncias. Tomando novamente a noção de (h)istória e (H)istória como os elementos constitutivos da subjetividade, trata-se de pensar, nessa investigação, dos modos de subjetivação marcados pelas vivências de violência históricas.

O transtraumático enquanto possibilidade de encontro entre analista e paciente no contexto descrito, se refere então a um inconsciente colonial. Nesse sentido, nos interessa pensar as modalidades de intervenção clínica que incluam os aspectos da dominação colonial como elementos também inconscientes na relação intersubjetiva do exílio hoje. Entre exilados já instalados e exilados recém-chegados, entre brasileiros e migrantes, entre europeus e refugiados, entre populações brancas e não brancas, assim como entre analista e analisando, o colonial insiste como dimensão também inconsciente. Mais do que somente um componente histórico presente nas relações sociais, tratamos de compreender a dimensão do poder colonial como um elemento inconsciente na relação intersubjetiva reatualizada pelas novas migrações.

Um pequeno fragmento clínico de uma situação observada pode nos trazer alguns elementos a mais para refletirmos brevemente sobre o contexto europeu. Desta vez em um 
centro de acolhimento público ${ }^{64}$ para refugiados recém-chegados na cidade de Paris, instituição em que alguns profissionais (assalariados e voluntários) também exilados - mas instalados na França já há mais tempo - cumprem funções técnicas de acolhimento, assistência e tradução. O encontro das mesmas nacionalidades culturas, línguas e religiões facilita a execução dos procedimentos, garante uma melhor recepção e reduz alguns dos malentendidos linguísticos e culturais próprios de um contexto de extrema vulnerabilidade.

No entanto, um mal-estar se anuncia de forma evidente nos espaços institucionais. A atividade desses profissionais é constantemente tomada por um sentimento de apatia e impotência na execução de tarefas relativamente simples. Na prática, essa apatia se traduz em longas esperas frente a exigências simples. Profissionais apáticos, executando minimamente e muito lentamente suas tarefas e evitando receber qualquer tipo de solicitação ou demanda, presença ausente, quase como se as próprias atitudes no espaço de trabalho viessem revelar algo do coletivo. Diante dessa constatação, decido tomar a apatia como uma espécie de sintoma institucional, algo que pudesse ilustrar a relação intersubjetiva entre profissionais exilados e exilados recém-chegados naquela instituição.

Nesse sentido, é possível pensar que os profissionais exilados que lá estão parecem exercer um papel profundamente ambíguo, e observando essa situação, vemos que essa ambiguidade é própria do lugar onde eles estão instalados e lhes retorna (aos profissionais, voluntários ou não) de uma maneira ou de outra de forma sintomática. Isto é, a apatia na atividade profissional como uma forma de tradução do desamparo vivido pelos exilados recém-chegados. A partir dessa pequena observação, podemos refletir sobre a ambivalência do inconsciente colonial que produz sintoma e sofrimento. Vamos a ela.

A chegada em um centro de acolhida temporário parece ser, para os exilados recémchegados, atravessada por uma dupla injunção contraditória: o fato de que finalmente foram acolhidos em um lugar com condições mínimas, lugar em que, diga-se de passagem, devem aceitar tudo (não se pode não aceitar, o que quer que seja); e, ao mesmo tempo, a desconfiança de estar diante da institucionalidade de um país que cometeu as mais diversas arbitrariedades em relação a eles e, para alguns, do país outrora colonizador. Isto é, como estabelecer confiança ou como se endereçar a essa instituição onde estão após terem atravessado todo o périplo para chegar até ali?

\footnotetext{
64 Trata-se de um abrigo construído pela prefeitura de Paris para acolher refugiados recém-chegados, mas também triá-los em função de um dispositivo de controle e expulsão. Tratamos melhor desse tema nos capítulos 1 e 2 da tese.
} 
Ao mesmo tempo em que a presença dos profissionais exilados permite um acolhimento mais eficaz - através da comunicação na mesma língua, do compartilhamento da mesma cultura e da identificação, eles mesmos parecem responder, igualmente, a demandas opostas: a da instituição que responde à triagem, ao controle e à expulsão, e a dos exilados, que é a do acolhimento e da resposta às necessidades de instalação e bem-estar. Desta forma, o desamparo vivido pelos exilados recém-chegados é traduzido pela impotência da ação dos profissionais diante dessas demandas. Trata-se, assim, da escuta de um sofrimento que revela um sistema de dominação social que perdura através do tempo. A tensão ilustrada por alguns dos fragmentos clínicos que trabalhamos remete à ambivalência da dominação colonial que é hoje presente também nas relações intersubjetivas do exílio.

Para além da presença histórica da colonização que continua a estruturar as relações sociais no mundo contemporâneo, queremos abordar também a presença inconsciente da relação de poder e da dominação colonial nas relações intersubjetivas. Nesse sentido, podemos falar de uma vida psíquica da história (BENEDUCE 2012, p.4) que deixa seu traços, marcas e pegadas na constituição subjetiva de cada sujeito imerso em seu tempo histórico, e que se reatualiza nas relações intersubjetivas do com o exilado.

Inconsciente, esse conflito se imprime também através de sintomas psíquicos que engendram mais sofrimento para o sujeito. Segundo Roberto Beneduce (2017), a colonização figura ainda como o grande recalcado da sociedade europeia, e assim, podemos nos perguntar até que ponto as novas chegadas de populações exiladas de países outrora colonizados reatualizam esse conflito e vêm interpelar não-ditos fundadores. A constituição subjetiva de cada indivíduo, atravessado então pela grande e pela pequena história, é marcada por essa dimensão colonial na forma de se conceber e se representar no mundo.

Nesse sentido, podemos partir da reflexão de que a dimensão histórica da dominação colonial, baseada na força, na exploração humana e no racismo durante séculos, produz a história das subjetividades contemporâneas. Tentamos pensar assim as possibilidades clínicas, através do transtraumático, de posicionamento e escuta diante desse conflito, uma vez que não se trata se mascarar ou de resolvê-lo, mas de fazê-lo, antes de tudo, emergir no discurso.

Tendo em vista a presença do colonial como um conflito também inconsciente, podemos pensar nos efeitos de invisibilização de uma intervenção clínica que não inclua esse componente. Para evitar, dessa forma, a invisibilização ou o desmentido, trata-se de pensar nas formas de reconhecimento e de intervenção nesse campo. 
Se as novas migrações vieram reatualizar conflitos latentes, propomos, por nossa parte, refletir sobre as formas de nos implicar nessa dinâmica, pensando em vias de encontro possível. Assim, através do transtraumático, quisemos pensar nas modalidades de compartilhamento e encontro do traumático que constitui cada interlocutor instalado na dinâmica da transferência, e fazer disso um lugar de encontro possível. Encontro clínico que tenha como direção a criação de condições para a restituição do político para o sujeito dimensão frequentemente estilhaçada pela violência do trauma.

Para não anular a escuta sobre um conflito que é tanto presente quanto fundador de diversos elementos constitutivos da subjetividade de cada indivíduo, trata-se de insistir sobre um posicionamento político do analista diante do trauma hoje. Ora, se o inconsciente colonial insiste em sua presença, ele deve ser não somente nomeado, mas incluído na dinâmica da transferência e endereçamento que crie condições de restituição do campo político para o sujeito outrora excluído pelas lógicas hegemônicas no mundo. 


\section{CONCLUSÕES OU QUANDO OS INDESEJÁVEIS DESEJAM}

À guisa de conclusão, voltamos ao prêambulo. Foi partindo de um desencontro inaugural que nos debruçamos ao longo da tese sobre as possibilidades de encontro e compartilhamento entre analista e analisando em contextos extremos. Na cena composta por agentes humanitários que preparam uma refeição tida como típica e dos exilados que atiram as mesmas ao mar denunciando o excesso de condimentos, vemos tanto o desencontro entre necessidade e desejo, entre oferta e demanda como, sobretudo, a potência de uma resposta de sujeitos que insistem em não se identificarem por completo ao lugar que lhes é constantemente atribuído. Sujeitos que parecem anunciar que não se reduzem aos lugares pelos quais são tomados. Aqui, humanitário é somente uma figura do discurso que ora homogeiniza, ou patologiza, criminaliza e vitimiza sujeitos que - dentre tantos aspectos, marcas, singularidades e atravessamentos - migram dos países mais pobres aos países mais ricos. O que fazer então quando os indesejáveis desejam? Na cena inaugural o que parece se instaurar é o embaraço, ou mesmo um certo ressentimento.

Ao longo da tese, tentamos refletir sobre as possibilidades de intervenção clínica que pudessem favorecer os modos pelos quais os sujeitos resistem às dinâmicas de aniquilação de sua condição desejante, e insistem em sua existência. Como insistência e resistência, portanto, pensamos nos diversos modos em que os sujeitos fazem das migrações - tanto desejadas quanto forçadas, modos de existência contemporâneos. As marmitas condimentadas atiradas ao mar desvelam, nesse sentido, a outra cena do discurso que produz indesejáveis. Aqui pensamos nos destinos vitais da pulsão de morte ou nos destinos mortíferos da pulsão de vida. Haveria potencial mais mortífero da pulsão de vida do que alimentar vítimas com rações condimentadas que simulam pratos familiares? No mínimo, poderíamos tomar como um insulto. Ao mesmo tempo, haveria potencial mais vital da pulsão de morte do que, mesmo com fome ou com homesick/mal du pays, sustentar a dignidade (SAGLIO-YATZIMIRSKY, 2016) de não ser tomado como um resto pelas mesmas políticas de aniquilação que pretendem deixar as populações tão somente em vida? No mínimo podemos tomar como um ato de resistência.

Com Zaltzman (1994), pensamos na pulsão política, pulsão revolucionária do sujeito diante de um extremo. Assim, as migrações atuais atravessadas pelas extremidades dos contextos a que nos referimos são tanto desejadas como forçadas em função do quanto os 
sujeitos façam valer dessa condição as vias de obter direitos (de trânsito e de instalação), mas também em todos os modos de existir no mundo.

Frente a essa questão que se apresenta, como podemos pensar em uma escuta analítica nesse contexto? Como pensar em intervenções que favoreçam as modalidades de resistência dos sujeitos aos discursos hegemônicos de dominação? Como sustentar uma escuta que não produza efeitos de desmentido nas vivências traumáticas dos sujeitos, nem pelo distanciamento excessivo e tampouco pelo excesso de implicação? Até que ponto o encontro é possível? Esse conjunto de questões foi norteador durante todo o processo da pesquisa que buscou sedimentar aportes clínico-teóricos para uma prática psicanalítica com pessoas em contextos de deslocamento, mas também em situações de sofrimento extremo na precariedade social. Desse modo, como dissemos, estrangeiro não é senão uma figura para pensar as vicissitudes do encontro clínico.

$\mathrm{O}$ front a que nos referimos na pesquisa é o da guerra reatualizada no vínculo com o analista. Um encontro marcado pelo caráter intempestivo dos atravessamentos da História na singularidade de ambos, analista e analisando, e o questionamento sobre as possibilidades de escuta. Portanto, frente aos casos que mobilizam afetos, pensamos na necessidade de fabricar elementos clínicos de intervenção que permanentemente sejam referidos tanto ao analista como ao analisando em uma escuta implicada na dimensão sócio-política do sofrimento (ROSA, 2016). Front é léxico militar para se referir à linha de frente de uma batalha, mas front também remete ao que está imediatamente em frente. Em inglês, temos o "in front of" como o "de frente para", e precisamente nesse sentido, pensamos ao longo da pesquisa nos extremos do encontro entre analista e analisando nesse contexto. Uma tese, portanto, sobre uma analista no front, sua transferência e todos os atravessamentos suscitados pelo encontro.

Frente a sujeitos elididos pelo desastre, enquanto analistas, nos vemos às voltas com formas de sofrimento que se caracterizam por sua gravidade, pelo nível de angústia e desorganização psíquica. Mulheres, homens, crianças, diversas pessoas que, em determinando momento, se confrontaram com a ruptura do laço, com a catástrofe do estilhaçamento daquilo que faz unidade no eu e no sentido de coletividade. Assim, pensamos nas possibilidades de reconstrução narrativa, de reconfigurações subjetivas pela via da experiência e da restituição do laço. Através de casos clínicos, vinhetas, fragmentos, reflexões e observações, nos deburçamos sobre a tentativa de transmitir as próprias fabricações clínicas lançadas mão a partir da experiência. 
Traumático como uma modalidade de sofrimento do sujeito diante de um acontecimento vivido como desastre é a noção de que partimos para pensar nas intervenções clínicas nesse campo, portanto. Como vimos, referimo-nos às formas de enlouquecimento relativas à destruição do laço com o semelhante e com a própria cultura, estilhaçamento da confiança e da transmissão, e a partir disso deparamo-nos igualmente a um paradoxo: o enlouquecimento, que, pela impossibilidade de inscrição do acontecimento como experiência, busca incessamentemente, a partir da repetição, alguma inscrição possível. Nesse sentido, o endereçamento adquire a potência daquilo que pode favorecer destinos de significação da experiência, restituição do laço e reinscrição política da catástrofe, em um tempo particular da imediatez em função da urgência dos casos.

No entanto, em paralelo a essa discussão há uma outra compreensão do traumático em jogo e em disputa no campo das migrações. E para trabalharmos a noção de trauma e experiência foi preciso nos situarmos em relação aos discursos hegemônicos nesse contexo. Isto é, a categoria de trauma também passou a figurar como uma nova linguagem do acontecimento e seu uso não se faz sem consequências. No âmbito humanitário de intervenção em saúde mental com as populações em trânsito pelo mundo, trauma passou a ser amplamente utilizado como uma categoria que tanto imprime uma concepção específica sobre o sofrimento, como define as tecnologias terapêuticas lançadas mão em campo. Desse modo, deslocamento vem sendo cada vez mais tomado em sua dimensão de perda e risco de adoecimento para o sujeito. Trata-se da compreensão do sofrimento como reação normal a eventos anormais e, portanto, nem singularizado nem politizado como experiência subjetiva.

Diferentemente da posição de que partimos, nos processos de patologização das migrações, deslocamento não é mais compreendido como uma experiência fonte de transmissão, produtora de encontros, descobertas, de história e de laço. Tampouco o sofrimento relativo à dimensão traumática é compreendido na singularidade de cada sujeito e na possibilidade de ressignificar o acontecimento como experiência. Tidos como presenças indesejáveis nos países mais ricos, migrantes são cada vez mais criminalizados e excessivamente patologizados em seu sofrimento. É importante pontuar uma vez mais que a proliferação da categoria de trauma no campo das migrações compreende uma determinada economia moral (FASSIN; RETCHMAN, 2007) que reverbera no apagamento da dimensão política dos deslocamentos contemporâneos. Vemos, assim, a patologização da experiência e a despolitização do sofrimento. A partir dessa discussão, propomos não a renúncia ao uso da 
categoria de trauma, senão determinado posicionamento em relação aos discursos dominantes no campo das migrações e seus efeitos para o sujeito, assim como um uso avisado de algumas de suas consequências políticas.

A partir da discussão sobre alguns desdobramentos dos discursos patologizantes acerca das experiências migratórias dos sujeitos, podemos pensar também na dimensão de criminalização desse mesmo fenômeno. Como vimos, as políticas de restrição e localização não cessam de produzir dispositivos de controle e impedimento, tanto do direito de livre trânsito, quanto de instalação. Nesse sentido, pensamos nas possibilidades não somente físicas de deslocamento e permanência, como nas formas em que os sujeitos possam fazer valer o trânsito e a instalação no duplo como possibilidades de enunciação de si e como modos de existência. Portanto, línguas, pertencimentos culturais e injunções institucionais incidem como elementos centrais na vivência de sujeitos migrantes, no contexto de intervenções clínicas e nas possibilidades de significação para o sujeito.

Por meio da figura do passador (HASSOUN, 1994), pensamos na posição de um analista-coiote como agente que favorece o atravessamento, o livre trânsito e a instalação no duplo entre línguas, culturas e fronteiras jurídico-institucionais. Compreendemos a presença das diferentes línguas e culturas nos atendimentos para além de uma especificidade da clínica com sujeitos migrantes, mas também como recurso que possa favorecer a remotangem de si nos contextos de desterritorialização e deslocamento. Tomamos os atravessamentos e a instalação entre diferentes línguas e culturas como elementos pelos quais o sujeito pode fazer do duplo pertencimento um duplo lugar de enunciação e não um impedimento, barreira ou escolha única. O analista-coiote diz, portanto, de uma posição tanto engajada quanto clandestina do analítico no que se refere às políticas hegemônicas de dominação e às possibilidades de resistência do sujeito diante disso.

Juntamente a esses elementos, consideramos as injunções institucionais presentes nas trajetórias dos sujeitos em trânsito ou no país de exílio como aspectos preponderantes a serem também incluídos. Para essa discussão, tomamos a questão da elegibilidade e da verdade nos procedimentos legais de solicitação de refúgio e seus atravessamentos subjetivos para pensar a posição do analista. Se a decisão das instâncias de elegibilidade se utiliza do critério da coerência e verdade da narrativa do solicitante acerca das razões que impeliram seu deslocamento, trata-se, de antemão, de um impasse moral sobre a necessidade de forjar narrativas críveis às institucionalidades para garantir a sobrevivência diante da regência de 
uma lógica da suspeição à palavra do refugiado. Desse modo, tanto as diferentes línguas, culturas e a incidência das injunções institucionais na vivência dos sujeitos são elementos que convocam o analista a incluir novas reflexões e diferentes posicionamentos. Aqui nos referimos às possibilidades de criar condições de emersão da palavra e de apropriação da própria narrativa, assim como à viabilidade de fazer de uma vivência fragmentada, experiência singular e política, concomitantemente. Trata-se, portanto, das possibilidades de atravessamento das distintas fronteiras em direção ao próprio desejo e com os próprios recursos do sujeito em trânsito.

De um lado, dissemos sobre algumas das vicissitudes de sujeitos marcados pela violência vivida em seus próprios fronts, a discussão sobre o traumático, sobre as distintas modalidades de trânsito e instalação entre línguas, culturas e injunções institucionais. De outro, tomamos o próprio analista diante desse encontro e tudo aquilo que lhe faz suscitar de seus próprios extremos. Isto é, pensamos no analista confrontado na estrangeiridade que repousa em seu íntimo. Para tal, tratamos de questionar aquilo que as migrações vêm acordar, revelar, e próprio processo de desalienação do analista diante dessas questões suscitadas. Por isso, discutimos alguns dos elementos que devem ser incluídos na dinâmica da transferência e no processo de elaboração - do paciente e analista, no sentido de não produzir efeito de desmentido da experiência.

Por mensageiros das más notícias ou como figuras do contemporâneo (AGAMBEM, 2009), tentamos mostrar de que forma os sujeitos recém-chegados das trajetórias de deslocamento vêm desvelar, com suas presenças em terra de exílio, modos próprios do funcionamento local, isto é, como efeito da mirada em um espelho em negativo, pensamos no quanto as presenças estrangeiras suscitam da própria estrangeiridade local repousada no íntimo. A chegada de novas populações parece anunciar (e denunciar) tanto a problemática da produção social do deslocamento, como também aspectos do funcionamento local do país de exílio. Nesse sentido, pensamos em dois elementos estruturantes da realidade brasileira que parecem ter sido particularmente interpelados através da chegada das "novas" migrações para o país, são eles: o racismo e a violência política. Ainda que tomemos o fenômeno do racismo como uma modalidade de violência política, quisemos diferenciar esses dois aspectos para abordar com mais contorno e, portanto, de forma mais visível, algumas das problemáticas da segregação em função da cor de pele. 
Desse modo, se nos propusemos a tratar do encontro do analista e paciente, também abordamos as vicissitudes de um outro encontro que parece figurar nesse contexto: o das populações recém-chegadas oriundas das "novas" migrações na realidade brasileira. Assim, quisemos investigar o que essas novas presenças de pessoas provenientes de determinadas situações geopolíticas acabaram por interrogar da sociedade brasileira e, nesse sentido, pensamos na negritude, branquitude e na violência política como analisadores fundamentais para a clínica.

Racismo e violência política são dois grandes elementos suscitados pelas novas presenças e seu efeito de denunciação, na medida em que se trata de sujeitos predominantemente negros e oriundos de países que vivenciam crises políticas agudas e vítimas de perseguições de ditaduras. Se, por um lado, essas parecem ser duas dimensões fundantes da realidade brasileira, também figuram, na mesma medida, como formas pelas quais a sociedade não se representa. Como vimos, tanto o mito da democracia racial quanto a impunidade e esquecimento dos crimes da colonização, da escravidão e da ditadura militar na história do país seguem operando como discursos hegemônicos e institucionalizados. Ambos convivem com uma realidade social profundamente atravessada tanto pela violência política como pela racial. É assim que as trajetórias de migrantes recém-chegados da República Democrática do Congo, de Angola, da Nigéria, do Camarões, de Serra Leoa, do Haiti, entre outros, vêm desvelar as formas pelas quais a própria sociedade brasileira não se reconhece.

É através da discussão de todos esses elementos que pensamos nos componentes que devem ser incluídos tanto na formação de um analista que se propõe a intervir nesse contexto, como nas dimensões que devem ser tomadas em sua própria escuta. Com Ferenczi (1932) pensamos na noção de desmentido para pensar nos efeitos de uma escuta que não é capaz de incluir as dimensões sócio-políticas do sofrimento (ROSA, 2016) e o próprio atravessamento traumático que constitui a subjetividade do analista. Isto é, efeitos na escuta de um analista que não reconhece e inclui, em si mesmo, a verdade do discurso do sujeito sobre o acontecimento.

Se falamos previamente sobre os estilhaçamentos do sujeito pela ruptura do laço, como pensar nas possibilidades de endereçamento no que se refere à fiabilidade e sustentação de sua escuta? É com essa reflexão que concluímos a pesquisa que se pretende investigar a posição do analista e as marcas do trauma na clínica com pessoas migrantes. De um lado, nos propusemos a pensar nas formas pelas quais os sujeitos - que tiveram a confiança em seu 
semelhante elidida pela violência disruptiva do desastre - podem vir a encontrar a possibilidade de se fiar novamente no endereçamento a um outro. De outro, as possibilidades de sustentação, para o analista, de uma escuta instalada no ângulo de uma boa distância entre o excesso de implicação e o distanciamento defensivo.

Partindo da própria clínica, abordamos as possibilidades de intervenção que têm como norteador a dimensão da escuta. Aqui tomamos escuta também em sua relação com o tempo e o espaço no encontro entre analista e analisando, ou seja, tanto em sua dimensão simbólica de emersão da palavra e elaboração do vivido, quanto presença física do corpo-ouvidoescuta(dor) do analista que produz continência, transbordamentos, atravessamentos e/ou pontos-cegos. Assim, pensamos tanto nas possibilidades de intervenção em relação ao tempo, que é o da urgência, a partir da imediatez, quanto ao espaço, que é o do front, para refletir sobre os ângulos de escuta que permitam um encontro de compartilhamento com o outro sem efeitos de desmentido.

É nessa perspectiva que propusemos situar o próprio traumático do analista para pensar nas possibilidades de compartilhamento no encontro com outro sujeito. Para isso, lançamos mão do conceito de transtraumático, que nos serviu para pensar sobre a posição do analista nos contextos extremos. Se concebemos o front analítico a partir da ideia do traumático reatualizado no vínculo da transferência com/do analista, pensamos nas formas de nomeação e reconhecimento da própria singularidade traumática do analista para criar condições de escuta e intervenção. Novamente, partimos da ideia de que dimensão de cruzamento entre a grande e a pequena história é também operante no processo de subjetivação do analista, e o que propusemos foi justamente tomar esse ponto como uma posição de sustentação da escuta.

Assim, transtraumático se refere à dimensão de compartilhamento, na transferência, do traumático que constitui cada sujeito. Oferta de endereçamento que vise tanto a garantir uma sustentação possível para o analista em relação ao seu próprio extremo (evitando assim tanto a indiferença quanto a mistura indissociada do sofrimento) como a restituir o laço e a possibilidade de significação da experiência para o sujeito. Desse modo, para pensar no ângulo do posicionamento transtraumático é necessário levar em conta o lugar em que o analista está situado e de onde ele fala, ou seja, nos atravessamentos da História em sua singularidade. 
Através de minha própria experiência, tomei dois significantes para pensar nessa dinâmica de distanciação do analista em relação aos seus próprios extremos; a branquitude, na realidade brasileira, e o colonialismo, na realidade francesa, dois contextos em que a pesquisa foi inscrita. Nesse sentido, pensamos na dimensão inconsciente das modalidades do poder colonial ainda presentes nas relações intersubjetivas. Por inconsciente colonial pensamos, portanto, nas marcas e atravessamentos das violências coloniais da história da constituição subjetiva de cada sujeito oriundo de seu tempo. Assim, podemos compreender a singularidade como sendo marcada por esse aspecto colonial, tanto na forma de se conceber como de se representar.

Branquitude é a dimensão racializada de meu próprio corpo nesse tempo histórico marcado pela violência contra corpos não-brancos que tanto atravessa a minha própria singularidade no processo de subjetivação quanto a relação com o outro. Trata-se, portanto, também de minha perspectiva traumática das marcas de uma violência que estruturou tanto os privilégios como meu próprio processo de subjetivação. Desse modo, o inconsciente colonial é pensado como o transtraumático na relação entre analista e paciente nesses contextos. Marcas do enigma traumático de uma violência histórica impressa na transgeracionalidade dos processos de subjetivação.

Tendo em vista essa discussão, sustentamos a dimensão do inconsciente colonial como um transtraumático para pensar as vias de incluir, na relação entre analista e analisando, os atravessamentos sócio-políticos do sofrimento psíquico. Processo de desalienação do analista, trata-se de pensar nas formas de levar em conta não apenas os principais discursos políticos, as distintas modalidades de poder e controle, as vicissitudes das diferenças culturais, linguísiticas e as incidências das injunções institucionais nas trajetórias de sujeitos em trânsito pelo mundo, como também as marcas que compõe o próprio analista e sua escuta.

Sobre essa questão é importante pontuar que não nos interessamos e nem nos propusemos a definir quem seria ou não autorizado a intervir com sujeitos nas mais diversas condições, tampouco quisemos propor uma posição culpada em relação às violências históricas perpetradas por determinado grupo social. Fudamentalmente quisemos sustentar a possibilidade de nomeação, reconhecimento e inclusão, na dinâmica da transferência, dos atravessamentos traumáticos do próprio analista naquilo que se refere às vivências do analisando. Em suma, pensamos ao longo da tese nos componentes a serem incluídos para uma escuta que possa ter como direção um encontro clínico que favoreça tanto as condições 
de restituição do campo político da experiência, como a própria dimensão desejante do sujeito.

A clínica com pessoas migrantes enuncia os contornos de diversas fronteiras (e aqui podemos tomar fronteira como atravessamento e permeabilidade) entre diferentes disciplinas, campos epistemológicos, e elementos a serem incluídos em sua reflexão. Através dessas reflexões e proposições quisemos contribuir, a partir de nossa própria experiência, na formação de outros analistas que se disponham a se instalar nos mais diversos fronts em que a clínica psicanalítica possa estar. Sabemos da complexidade do tema e da imensidão de discussões a serem aprofundadas e incluídas ainda nesse debate. No entanto, através do ângulo de nossa escuta, propusemos que essas questões fossem levadas em conta na intervenção com sujeitos migrantes atualmente.

Assim, em nossa reflexão sobre as diferentes posições ocupadas pelo analista em relação aos discursos hegemônicos que marcam as vivências dos sujeitos em trânsito e do próprio analista, várias foram as metáforas para a elaboração de um pequeno glossário que pudesse abarcar as especificidades desse campo.

Diante dos botes infláveis superlotados que erram pelo Mediterrâneo, sustentamos a possibilidade de uma escuta que favoreça a ancoragem em terra de exílio através de uma presença-porto no encontro com o analista. Diante das questões de mobilidade e instalação em uma nova cidade, pensamos em um analista desterritorializado de seu setting tradicional e que faz de sua própria circulação modos próprios de escuta. Diante da proliferação dos muros e barreiras de impedimento de passagem e do discurso de criminalização às migrações, pensamos nas intervenções de um analista-coiote no sentido de criar condições para o livre trânsito, instalação e, do duplo como possibilidade de enunciação para o sujeito. Diante da gramática de patologização do sofrimento e da compreensão das migrações como fator de risco, propomos a escuta do enlouquecimento como tentativa de representação, politização do acontecimento e da experiência. Diante das retóricas da urgência humanitária que toma o sujeito como vítima; a possibilidade da intervenção na imediatez. Diante da hiper-implicação ou do distanciamento excessivo em casos que mobilizam afetos, a distanciação como ângulo de posicionamento da escuta. Diante do desmentido do traumático da violência colonial que marca o encontro com o outro, a perspectiva de um transtraumático como possibilidade de compartilhamento. 
Desse modo, sustentamos o caráter clandestino da psicanálise (ou pestilento, no sentido freudiano) diante da violência dos discursos hegemônicos de aniquilamento das populações mais pobres ao redor do mundo. Nos interessamos pela dimensão da clínica que favoreça, por meio do encontro, as modalidades de resistência dos sujeitos em suas formas mais criativas de existência. A partir das experiências brasileiras e francesas, quisemos fomentar reflexões sobre as intervenções do analista nos contextos geopolíticos que atravessam o campo das migrações contemporâneas em sua realidade de precariedade social e violência extrema. Sendo assim, esperamos ter contribuído com considerações teóricoclínicas que procuraram incluir possíveis modos de desalienação do analista em relação aos discursos hegemônicos e no sentido das potencialidades de circulação, instalação e desejo dos sujeitos. Em suma, compreendemos as migrações como um fenômeno de deslocamento humano propulsor de múltiplas possibilidades de remontagens subjetivas, como reinvenções de novos modos de existência e, sobretudo, enquanto formas potentes de resistência na contemporaneidade. 


\section{REFERÊNCIAS BIBLIOGRÁFICAS}

ACHOTEGUI, J. La crisis como factor agravante del Síndrome de Ulises. Temas de Psicoanalisis. n. 3, 2012.

AGAMBEN, G. O que é o contemporâneo? E outros ensaios. Editora Argos. Chapecó, 2009.

AGIER, M. Les migrants et nous: comprendre Babel .Paris: Editions CNRS, 2016. Paris.

Gérer les indésirables: Des camps de réfugiés au gouvernement humanitaire. Paris: Flammarion, 2008.

Refugiados diante da nova ordem mundial. Tempo social v.18 n.2. nov. 2006.

Aux bords du monde, les réfugiés. Paris: Flammarion, 2002.

ALVES, J. A. L. A declaração dos diretos humanos na pós-modernidade. Revista da AMB, Ano 2, n 5, p, 6-13, 1998. Disponível em: http://www.egov.ufsc.br/portal/sites/default/files/a_declaracao_dos_direitos_humanos_na_po s-modernidade.pdf. 1998.

AMORIM, C. (2003) O Brasil e o renascimento africano. Folha de São Paulo (online). 25 de mai, 2003. Tendências e debates. Disponível em: https://www1.folha.uol.com.br/fsp/opiniao/fz2505200308.htm.

ANDRADE, V. L. Imigração e sexualidade: solicitantes de refúgio, refugiados e refugiadas por motivos de orientação sexual na cidade de São Paulo. Dissertação (Mestrado em Antropologia Social). Universidade Federal de Santa Catarina, Florianópolis, 2017.

ARENDT, H. (1968) Homens em tempos sombrios. São Paulo: Ed. Companhia das Letras, 1987.

. (1958) A condição humana. 10a ed. Rio de Janeiro: Forense Universitária, 2007.

(1949) As origens do totalitarismo: antissemitismo, imperialismo, totalitarismo.

São Paulo: Cia das Letras, 2012.

. (1943) Nós, os refugiados. Covilha: Universidade da Beira Interior (Trad. Ricardo Santos), 2013.

AYOUCH, T.; BOULAMAH, L. C. A homossexualidade dos analistas: História política e metapsicologia. Revista Percurso, 51, dez. p.115-126, 2013.

Psicanálise e homossexualidades: teoria, clínica, biopolítica. Curitiba: CRV, 2015. 
AZAMBUJA, M. Le dectetive Flanêur. In: Et puis un jour, nous perdons pied.

Paris: Gallimard, Paris, 2010.

BA“A“RNHIELM, S. et al Mental health for refugees, asylum seekers and displaced persons: A call for a humanitarian agenda, Transcultural Psychiatry, v, 54 (5-6) 565-574, 2017.

BAUMAN, Z. Mensajeros de la globalizacion . El pais. 31 de outubro de 2015.

BAYART, J.F.; BENEDUCE, R.; TALIANI, S. La vie psychique du pouvoir colonial, Esprit, p. 97-111, Oct 2017.

BENEDUCE, R. La vie psychique de l'Histoire. Fanon et le temps fracturé de la mémoire, L'Autre, v.13, p. 273-284, mai 2012.

L'apport de Frantz Fanon à l'ethnopsychiatrie critique. VST - Vie sociale et traitements, no 89, p.85-100, jan 2006.

BENJAMIN, W. (1938). Paris do Segundo Império. ln: Obras escolhidas, v. III. (Trad. José Carlos Martins Barbosa, Hemerson Alves Baptista. São Paulo, Ed. Brasiliense, 1989.

BENJAMIN, W. (1936) O narrador. In: Magia e técnica, arte e política. São Paulo: Editora Brasiliense, 1996.

BENTO, M.A.S. Branquitude: o lado oculto do discurso sobre o negro. In: I.CARONE \& M.A.S.BENTO (Orgs) Psicologia social do raciscmo: estudos sobre branquitude e branqueamento no Brasil. Petrópolis: Vozes, 2002.

BETTELHEIM, B. Sobrevivência e outros estudos. Porto Alegre: Editora Artes Médicas, 1989.

BIGO, D. The (in)securitization practices of the three universes of EU border control: Military/Navy - border guards/police - database analysts. Security Dialogue v. 45(3) 209$225,2014$.

BIRMAN, J. A biopolítica na genealogia da psicanálise: da salvação à cura. História, Ciências, Saúde-Manguinhos, Rio de Janeiro, v. 14, n.2, p. 529-548, abr.-jun., 2007.

BLANCHOT, M. L’écriture du desastre. Paris: Gallimard, 1980.

L'entretien infini. Paris: Gallimard, 1969.

BOUAGGA, Y. De Lesbos à Calais: comment l'Europe fabrique des camps. Neuvy-enChampagne: Editions le passager clandestin, 2017.

BOURBOULON, V.; SANDLARZ, E. De la violence politique au traumatisme. Paris: L'Harmattan, 2007.

BOURDIEU, P. (coord.) La Misère du Monde. Paris: Éditions du Seuil, 1993. 
BRAGA, A.P.M. Os muitos nomes de Silvana: contribuições clínico-políticas da psicanálise sobre mulheres negras. 2015. 288 f. Tese (Doutorado). Instituto de Psicologia, Universidade de São Paulo, São Paulo, 2015.

; ROSA, M. D. Articulações entre psicanálise e negritude: desamparo discursivo, constituição subjetiva e traços identificatórios. Revista da ABPN • v. 10, n. 24 • nov.2017 fev. 2018, p.89-107.

BRASIL. Lei no. 13.445/2017. Institui a Lei de Migração. Disponível em: http://www.planalto.gov.br/ccivil_03/_Ato2015-2018/2017/Lei/L13445.htm. Acesso em: 23 nov 2017.

BRASIL. Lei $n^{\circ}$ Lei $n^{\circ}$ 6.815, de 19/8/1980. Define a situação jurídica do estrangeiro no Brasil, cria o Conselho Nacional de Imigração, e dá outras providências. Disponível em: http://www2.camara.leg.br/legin/fed/lei/1980-1987/lei-6815-19-agosto-1980-366138-normapl.html. Acesso em: 23 nov 2017.

BRESSER-PEREIRA, L.C. A crise financeira global e depois: um novo capitalismo? Novos Estud. Cebrap, no 86,São Paulo, mar 2010.

CALVINO, I. Cidades Invisíveis. São Paulo: Companhia das Letras, 1972.

CAPOGNA-BARDET. G. Clinique du Trauma. Paris: Editions Erès, 2014.

CARMO-HUERTA, V.; MORO, M. R. Incidências da transmissão dos traços de cultura no processo de subjetivação da criança e do adolescente migrante. Revista APPIA, no 37, 2014.

CASANOVA, B. Psychanalyse et langue maternelle. Langue française, no. 54. p.108-113. 1982.

CASSIN, B. Plus d'une langue. Paris: Bayard Éditions, 2012.x

CARONE, I. Breve histórico de uma pesquisa psicossocial sobre a questão racial brasileira. In: I. Carone \& M.A.S. Bento Psicologia social do racismo - estudos sobre branquitude e branqueamento no Brasil. Petrópolis: Vozes, 2002.

CARONE, I. ; BENTO, M. A. S.(Orgs) Psicologia Social do Racismo: estudos sobre branquitude e branqueamento no Brasil. Petrópolis (RJ): Editora Vozes, 2002.

CELAN, P. A morte é uma flor: poemas do Espólio. (Trad. João Barrento). Lisboa: Cotovia, 2017.

CERRUTI, M.; PERDOMO M. C. Trauma, memória e transmissão: a incidência da política na clínica psicanalítica. São Paulo: Primavera Editorial, 2011. 
Bate-se em uma mulher: impasses da vitimização. Dissertação (Psicologia Clínica). Universidade de São Paulo. 2007

CÉSAIRE, A. Discours sur la négritude. Paris: Editions Présence Africaine, 2004.

(1950). O discurso dobre o colonialismo. Lisboa: Livraria Sá da Costa, 1978. Disponível em: https://antropologiadeoutraforma.files.wordpress.com/2013/04/aime-cesairediscurso-sobre-o-colonialismo.pdf. Acesso em 15 mai 2016.

CHNAIDERMAN, M. Buscando baobás na aridez do asfalto: instaurando origens. Revista Eletrônica de Educação, v. 9, n. 2, p. 519-535, 2015.

CLAUDEL, P. Le rapport Brodeck. Paris: Stock, 2007. 400 p

COATES, T-N. Between the world and me. New York : Penguin Random House, 2015.

CONVENÇÃO para a prevenção e repressão do crime de genocídio, 1948. Disponível em: http://pfdc.pgr.mpf.mp.br/atuacao-e-conteudos-deapoio/legislacao/segurancapublica/convenca....crime_genocidio.pdf. Acesso em 11 ago 2015.

CONVENÇÃO relativa ao estatuto dos refugiados, 1951. Disponível em:

http://www.acnur.org/fileadmin/Documentos/portugues/BDL/Convencao_relativa_ao_Estatut o_dos_Refugiados.pdf. Acesso em 15 ago 2015.

CORIN, E. De quel reste à venir la psychanalyse est-elle le nom ? Entretien avec Ghyslain Lévy, Filigrane, 21(2), 85-109, 2012. Disponível em: https://www.erudit.org/fr/revues/fili/2012-v21-n2-fili0541/1015200ar.pdf. Acesso em 20 jun 2018

CORTINA ORTS, A. Aporofobia, el rechazo el pobre : un desafío para la democracia. Barcelona: Paidós, 2017.

COSTA, A. Um luto impossível: efeitos de trauma em imigrações In ROSA; CARIGNATO, T. T.; ALENCAR, S. L. (Orgs) Desejo e Política: desafios e perspectivas no campo da imigração e refúgio. São Paulo: Ed. Max Limonad, 2013.

COSTA, J.F. Da cor ao corpo : Violência e Psicanálise. Rio de Janeiro: Edições Graal, 1984 ( texto original como prefácio ao livro "Tornar-se negro", de Neusa

Souza).

DAVOINE, F.; GAUDILliÈRE, J. M. Histoire et trauma: la folie des guérres. Paris: Editions Stock, 2006.

; et al. Folie et lien social.Annuaire d'Ehess 2007-2008, p. 452-456. Disponível em: https://journals.openedition.org/annuaire-ehess/19418?lang=en. Acesso em: 20 jan 2018. 
DAVOUDIAN, C. L'exilé : sujet idéologique. Exilé et "sans papiers", 2015.Disponível em: $\quad$ http://olivierdouville.blogspot.com/2015/04/lexile-sujet-ideologique-exile-etsans.html.Acesso em 12 se 2017.

Mères et bebes sans papies. Paris: Erès, 2014.

DE GAULEJAC, V., HANIQUE, F., ROCHE, P. La sociologie clinique, enjeux théoriques et méthodologiques. Paris: Eres, 2007.

D'ELIA, H. De la névrose traumatique aux traumas de la névrose ? In|: G. CAPOGNABARDET (Org.) Clinique du Trauma,. Paris: Editions Erès, 2014, pp. 15-32.

DELEUZE, G. Que és un dispositivo? In: BALIBAR, E.; DREYFUS, H.; DELEUZE, G. et al. Michel Foucault, filósofo. Barcelona: Gedisa, 1999, p. 155-163. DERRIDA, J. O animal que sou (a seguir). (Trad. Fábio Landa). São Paulo: Editora UNESP, 2002. Disponível em : https://edisciplinas.usp.br/pluginfile.php/1563761/mod_resource/content/1/Jacques\%20Derrid a. $\% 200 \% 20$ animal\%20que\%20logo\%20sou.pdf

; GUATTARI, F. (1997) Mil Platôs: capitalismo e esquizofrenia. Vol. 5. Rio de Janeiro: Ed. 34.

DERRIDA, J; DUFOURMANTELlE, A. De l'hospitalité: Anne Dufourmantelle invite Jacques Derrida à répondre. Calmann-Lévy. Paris: Calman Levy,1977.

Le Monolinguisme de l'autre. Paris: Ed. Galilé, 1996.

DEVEREUX, G. Essais d'ethnopsychiatrie générale, Paris: Gallimard, 1970.

(1965) La renonciation à l'identité, défense contre l'anéantissement, Petit |Bibliothèue Payot, Paris, 2009.

Fábio Landa.

(1999) O animal que sou (a seguir). São Paulo: Editora UNESP, 2002. Tradução

DOGVILLE. Direção de Lars von Trier, prod. Vibeke Windeløv (2h 57min) Versão 2 DVDs Zentropa Entertainments, 2003.

DOUVILLE, O. Les figures de l'autre. Paris: Dunod, 2014.

DROTBOHM, H. Paredes porosas: Protecão fragmentada em face do deslocamento de migrantes no Brasil. Migramundo, 2016. Disponível em: http://migramundo.com/paredesporosas-protecao-fragmentada-em-face-do-deslocamento-de-migrantes-no-brasil/. Acesso em 20 ago 2015.

DUNKER, C. Mal-estar, sofrimento e sintoma: uma psicopatologia do Brasil entre muros. São Paulo: Boitempo Editorial, 2015. 
ELIACHEFF, C.; LARRIVIÈRE, D. S. O tempo das vítimas. São Paulo. Editora FapUnifesp, 2012.

ENDO, P. C. (2016) Sonhar o desaparecimento forçado de pessoas: impossibilidade de presença e perenidade de ausência como efeito do legado da ditadura civil-militar no Brasil, Psicol. USP [online]. v.27, n.1, pp.8-15, 2016.

ENRIQUEZ, E. (1998) O judeu como figura paradigmática do estrangeiro. In: C. KOLTAIN(Org.) O estrangeiro. São Paulo: Escuta, p.37-60, 1998.

FANON, F. (1952) Peau noire, masques blancs. Paris: Les Editions du Seuil, 1971.

Disponível (1961) Les damnés de la terre. La Découverte. Paris: La Découverte/Poche. 2002. https://monoskop.org/images/9/9d/Fanon Frantz Les damn\%C3\%A9s de la terre 2002.pdf . Acesso em 20 dez 2017.

FARHAT, R. Um discurso alinhado com diretrizes internacionais. combate ao tráfico de pessoas. Entrevista com Guilherme Mansur. Le Monde Diplomatique (online) Disponível em: https://diplomatique.org.br/combate-ao-trafico-de-pessoas/. Acesso 12 de abril 2016.

FASSIN, D. Le monde à l'épreuve de l'asile: essai d'anthropologie critique. Nanterre: Publications de la Société d'ethnologie, 2017. p. 26

Uma hospitalidade ambígua : A administração dos indesejáveis. In: M. D. ROSA et al (Orgs). Desejo e política : desafios e perspectivas no campo da migração e refúgio. São Paulo: Max Limonad, 2013.

La Rasion Humanitaire: une histoire morale du temps présent. Paris: Editions du Seuil, 2010. 358p

Les politiques de l'ethnopsychiatrie: La psyché africaine, des colonies africaines aux banlieues parisiennes. Revue L'Homme, 153, p.231,250, jan-mars, 2000.

.; RECHTMAN, R. L'empire du traumatisme: enquête sur la condition de victime. Paris: Flammarion, 2007.

FAUSTINO, D. M. Frantz Fanon: um revolucionário particularmente negro. Ciclo Contínuo Editorial. São Paulo, 2018.

FAVRET-SAADA, J. "Être Affecté". Gradhiva: Revue d'Histoire et d'Archives de l'Anthropologie,8, p.3-9, 1990.

FERENCZI, S. (1932) Confusion de langue entre les adultes et l'enfant. Paris: Éditions Payot \& Rivages, 2016.

Fontes, 1990.

(1932).Bandagem psíquica. In: Diário cínico. São Paulo: Martins 
. (1934) Le traumatisme. Paris: Éditions Payot \& Rivages, 2006.

. (1932) Diário Clínico. São Paulo: Martins Fontes, 1996.

. Réflexions sur le traumatisme. In: Euvres complètes, iv, 1927-1934, Paris: Payot, p. 139-147, 1982.

(1932) Journal Clinique (janvier-octobre 1932). Paris: Payot, 1990.

(1933). Confusão de línguas entre os adultos e a criança. In:

Psicanálise

IV (pp. 111-121). (Trad. Á. Cabral). São Paulo: Martins Fontes, 2011.

FERNANDES, F. A Integração do Negro na Sociedade de Classes.v.I : O Legado da Raça Branca. São Paulo: Editora Globo, 1964.

FERREIRA, A. B. de H. Dicionário Eletrônico Aurélio Século XXI. Rio de Janeiro: Editora Nova Fronteira e Lexikon Informática, 1999. Versão 3.0. 1 CD-ROM.

FIGUEIRA, S. A. (1994) Contratransferência: de Freud aos contemporâneos. São Paulo: Casa do Psicólogo, 1994.

FIGUEIREDO, I. Caderno de memórias coloniais. São Paulo: Editora Todavia, 2015.

FOUCAULT, M. Aula de 17 de março de 1976. In: Em defesa da sociedade. p.285-315. São Paulo: Martins Fontes, 1999. Disponível em: https://daletrasunipampa.files.wordpress.com/2013/11/53985530-revisado-foucault-m-aulade-17-de-marco-de-1976.pdf. Acesso em 11 set 2016.

1994.

Resumo dos Cursos do College de France (1970-1982). Rio de Janeiro: Zahar, . Ditos e escritos. Paris: Gallimard, 1976.

. (1969) Arqueologia do saber (Trad. Luiz Felipe Baeta Neves. Rio de Janeiro: Forense Universitária, 1972.

. (1966) Palavras e as coisas. São Paulo: Martins Fontes, 1981.

(1963) Nascimento da Clínica. (Trad. Roberto Machado. 2. ed. Rio de Janeiro:

Forense Universitária, 1980.

FREUD, S. (1932) Por que a Guerra? Edição Standard Brasileira das Obras Psicológicas Completas de Sigmund Freud. v. xxii. Rio de Janeiro: Imago, 1976. . (1929) O Mal-Estar na Civilização. Edição Standard das Obras Completas de Sigmund Freud. Vol. Rio de Janeiro: Imago, 1996. 
. (1920). Além do Princípio do Prazer" Edição Standard das Obras Completas de Sigmund Freud, Vol. XVIII. Rio de Janeiro: Imago, 1996.

. (1919) L’inquiétante étrangeté et autres textes. Paris: Folio, 2001.

(1919). O inquietante. História de uma neurose infantil (O homem dos lobos): além do princípio do prazer e outros textos. (Trad. Paulo César de Souza). São Paulo: Companhia das Letras, p. 328-376, 2010.

. (1915). Considerações atuais sobre a guerra e a morte. Obras Completas v. 12, p. 209-246). São Paulo: Companhia das Letras, 2015.

. (1904). Sobre psicoterapia. Edição standard brasileira das obras psicológicas completas de Sigmund Freud (Trad. J. Salomão), v. 7, p. 267-278)). Rio de Janeiro: Imago, 1969. (Trabalho original publicado em 1904)

. (1900). A interpretação dos sonhos. In: Edição standard brasileira das obras psicológicas completas de Sigmund Freud. v. 4,5. 2.ed. Rio de Janeiro, Imago, 1987.

GAILLARD,G. et al. Rencontre avec Alain-Noël Henri. Paris: Ères, 2011.

GALITZINE-LOUMPET, A. Exil (objets. In: Z.BERND (ORg.) Glossaire des mobilités culturelles, Bruxelles:P.I.E.Peter Lang, 2014

GALLI, G. 9 em cada 10 mortos pela polícia no Rio de Janeiro são negros ou pardos. Instituto Vladimir Herzog, 27 jun 2017. Disponível em: http://vladimirherzog.org/9-emcada-10-mortos-pela-policia-no-rio-de-janeiro-sao-negros-ou-pardos/. Acesso em: 14 jul 2016.

GEBRIM, A. C. C., "L'inconscient colonial dans la relation intersubjective avec l'exilé. In: A. Galitzine-Loumpet A. et Saglio Yatzimirsky (Dirs), Journal des Anthropologues, Edição especial "Subjectivités face à l'exil". No prelo (2018).

L'insistance de l'étranger: la double appartenance des lauréats du Prix de l'Intégration en France. Dissertação (Mestrado). Université Paris Diderot - Paris 7, Paris, 2012.

; GLEICH, F. Notícias do mar: sobre corpos não desejados e a política dos deslocados. Le Monde Diplomatique Brasil, 15 jun 2015.

GIUST-DESPRAIRIES, F. Une èpistémologie du certain. In: E. ENRIQUEZ et al (Orgs) Entre social et psychique: questions épistémologiques, Paris: L'Harmattan, 2009.

GLISSANT, E., CHAMOISEAU, P. Quand les murs tombent : l'identité nationale hors la loi ? Paris: Editions Galaade, 2012.

GONÇALVES FILHO, J.M. Humilhação social: Um problema político na psicologia. Psicologia USP, São Paulo, v.9, n.2, p.11-67, 1998. 
GONDAR, J. Um racismo desmentido. In: VI CONGRESSO NACIONAL DE PSICANÁLISE, DIREITO E LITERATURA, Minas Gerais, 2017a.

.O analista como testemunha. In: E. S. Reis, \& J. Gondar (Eds.), Com Ferenczi: clínica, subjetivação, política. (pp. 186-198). Rio de Janeiro: 7 Letras, 2017 b.

jul./dez. 2012.

Ferenczi como pensador político. Cad. Psicanál. CPRJ, v. 34, n. 27, p. 193-210,

GORDIMER, Nadine. O Engate (Trad. Beth Vieira). São Paulo: Companhia das Letras, 2004.

GORDON, L.R. What Fanon said: A philosophical introduction to his life and thought. New York, Fordham University Press, p.191. 2015

GRESH, A. (2010) De quoi la Palestine est-elle le nom ? Le Monde Diplomatique, 23 mars 2009. Dspoinível em: https://blog.mondediplo.net/2009-03-23-De-quoi-la-Palestine-est-ellele-nom. Acesso em: 22 ago 2017.

GUERRERO, O.; Malhou, A. Clinique: éthique et politique: les enjeux dans le soin aux personnes victimes de la torture et de la violence politique. Paris: Éditions de l'Association Primo Levi, 2010.

HANIQUE, F., 2009. Enjeux théoriques et méthodologiques de la sociologie clinique. Informations sociales, v.6, n.156, 2009.

HARVEY, D. O enigma do capital: e as crises do capitalismo. Editora Boitempo, 2011. (1989) A condição pós moderna. Loyola, 1992.

HASSOUN, J. O estrangeiro: um homem distinto. In: C. KOLTAI. O estrangeiro (Org.) São Paulo: Ed. Escuta, 1998.

Les contrabandiers de la mémoire. Toulouse: Ed. Erès, 1994.

L'exil de la langue. Paris. Ed. Point Hors Ligne, 1993.

Fragments de langue maternelle: Esquisse d'un Lieu. Paris: Payot, 1979.

HOLLANDA, C.B. Budapeste. São Paulo: Companhia das Letras, 2003.

IRAGO, D. Le demandeur d'asile aux prises avec le dehors et le dedans. Cliniques, n. 2, p. 138-162, feb 2011.

JAIME, P., \& LIMA, A. Da África ao Brasil: entrevista com o Prof. Kabengele $\begin{array}{llll}\text { Munanga. Revista } & \text { De } & \text { Antropologia, 56(1), } & \text { 507-551, }\end{array}$ file:///D:/Dados/Downloads/64518-Texto\%20do\%20artigo-85235-1-10-20131112.pdf 
KEHL, M. R. Os crimes do Estado se repetem como farsa. Folha de São Paulo. 24 mar 2013.

KNOBLOCH, F. Impasses no atendimento e assistência do migrante e refugiados na saúde e saúde mental. Psicol. USP [online], v.26, n.2, pp.169-174, 2015. Disponível em: http://www.scielo.br/scielo.php?script=sci abstract\&pid=S010365642015000200169\&lng=pt\&nrm=iso. Acesso em: 14 abr 2016.

O tempo do traumático. São Paulo: Educ Fapesp, 1998.

Impasses no atendimento e assistência do migrante e refugiados na saúde e saúde mental. Psicologia USP, v. 26, no 2, p. 169-174, 2015.

No exílio da doença: polifonias subjetivas. Cadernos de Psicanálise, v. 29, p. 304.

KOBELINSKY, C. L'asile gay: jurisprudence de l'intime à la Cour nationale du droit d'asile. Droit et société, v. 82,(3), 583-601, 2012. Disponível em: https://www.cairn.info/revue-droit-et-societe1-2012-3-page-583.htm. Acesso em: 14 set 2017.

KOLTAI, C. Psicanálise e Política: o estrangeiro. São Paulo. Ed. Escuta, 2000.

2013.

. Memória do inominável. In. M. C. Perdomo, \& M. Cerruti (Orgs) Trauma, Memória e Transmissão: a incidência política na clínica psicanalítica. São Paulo: Ed. Primavera Psi Sedes Sapientiae, 2011.

A segregação, uma questão para o analista. In: C. KOLTAI (Org.) O estrangeiro. São Paulo: Ed. Escuta, 1998.

O estrangeiro: um conceito limite entre psicanalítico e político. Tese (Doutorado em Psicologia) Pontifícia Universidade Católica de São Paulo, São Paulo, 1997.

LANCETTI, A. (2011) Clínica peripatética. Editora Hucitec. São Paulo, 2011. Disponível em: https://taymarillack.files.wordpress.com/2017/09/lancetti-clinica-peripatc3a9tica.pdf. Acesso em: 14 abr 2018.

LAPLANCHE, J; PONTALIS, J-B. Vocabulaire de psychanalyse. Paris: Presses Universitaires de France, 1967.

LEVI, P. É isto um homem? Rio de Janeiro: Editora Rocco. Rio de Janeiro. 1988.

MOGROVEJO, N. Sexilio politico. Nov. 22. Disponível em http://normamogrovejo.blogspot.com/2012/11/sexilio-politico.html. Acesso em: 16 jul. 2014 .

MAKAREMI, C. Penalización de la circulación y reconfiguración de la frontera: el mantenimiento de los extranjeros en "zonas de espera". (Trad. M.M.de Almagro), Cultures \& Conflits, 16 mars 2009. 
MBEMBE, A. Necropolítica. São Paulo: N-1 Editora, 2018.

MELMAN, C. Os efeitos subjetivos da migração linguística. In: E. G. MUSSNICH, Um inconsciente pós-colonial, se é que ele existe. Porto Alegre: Artes e ofícios, 2000.

MEZAN, R. Freud: O pensador da cultura. São Paulo: Ed. Brasiliense, 1985.

MIGREUROP:Atlas des migrants en Europe: géographie critique des politiques migratoires. Paris: Armand Colin, 2012 (Atlas).

MOURA GONÇALVES FILHO, J. Humilhação social: Um problema político em psicologia. Revista de Psicologia USP, v. $9 \mathrm{n}^{\circ}$. 2, 1998.

MUSATTI-BRAGA, a.p Os muitos nomes de Silvana: contribuições clínico-políticas da psicanálise sobre mulheres negras. Tese (Psicologia Clínica). Universidade de São Paulo, 2015 .

NASIO, J-D. Como trabalha um psicanalista? Rio de Janeiro, Jorge Zahar Editor, 1999.

NATAN, T. L’influence qui guérit. Paris: Ed. Odile Jacob, 1994.

La folie des autres: traité d'ethnopsychiatrie clinique. Paris: Dunod, 1986.

NEUBURG, R., (2009) Préface. In: G. DEVEREUX, G. (Org) La renonciation à l'identité, défense contre l'anéantissement, Paris: Payot \& Rivages, 2009.

NOUCHI, F. Philippe Claudel : Brodeck, ce héros. Le monde fr. 30.08.2007. Disponível em: $\quad$ https://www.lemonde.fr/livres/article/2007/08/30/philippe-claudel-brodeck-ceheros_949172_3260.html\#qW8J7AqFHfUokF7c.99. Acesso em 12 set 2017).

NUSELOVICI (NOUSS), A. Pensar o exílio e a migração hoje. (Trad. Ana Paula Coutinho Mendes. Porto: Afrontamento, 2016.

OCARIZ, M. C. O sintoma, para além da significação. In: Ciclo de Debates do Departamento de Psicanálise do Instituto Sedes Sapientiae, 29 abr 1999.

OLIVEIRA, A. T. R. Nova lei brasileira de migração: avanços, desafios e ameaças. 4 Rev. bras. Estud. popul., vol.34 no.1 Jan.Abr. 2017.

ONUBR. ACNUR: número de pessoas deslocadas chega a 68,5 milhões em 2017, 19/6/2018.Disponível em: https://nacoesunidas.org/acnur-numero-de-pessoas-deslocadaschega-a-685-milhoes-em-2017/. Acesso em: 20 mai 2017.

ORTIGUES, M. C.E. Édipo africano. São Paulo: Editora Escuta, 1989.

PALBERT, P. P. Introdução. In: LANCETTI, A. (Org.) Clínica peripatética. São Paulo: Editora Hucitec, $2008 . \quad$ Disponível em: 
https://taymarillack.files.wordpress.com/2017/09/lancetti-clinica-peripatc3a9tica.pdf. Acesso em: 09 fev 2017.

PESTRE, E. La vie psychique des réfugiés. Paris: Payot, 2010.

.; BENSLAMA, F. (2011). Traduction et traumatisme. Recherches en psychanalyse, n. 11, jan, 2011. 212 pages, [online] www.cairn.info/revue-recherches-enpsychanalyse-2011-1.htm.

PINHEIRO-GUIMARÃES, S. O desafio sul americano. Carta Maior: O Portal da Esquerda, 2012. Disponível em: https://www.cartamaior.com.br/?/Especial/America-do-Sulos-rumos-da-integracao/Samuel-Pinheiro-Guimaraes-O-desafio-sul-americano/88/25617.

Acesso em: 20 nov 2017.

PIZA, E. (2002) Porta de vidro: entrada para a branquitude. In: I Carone, I. \& M. A.S. Bento (Orgs) (2002) Psicologia Social do Racismo: estudos sobre branquitude e branqueamento no Brasil. Petrópolis (RJ): Editora Vozes, 2002.

PORCHAT, P. Prefácio. In: T. AYOUCH, T. (Org.) Psicanálise e homossexualidades: teoria, clínica, biopolítica. Curitiba: Editora CRV, 2015.

PROJETO de resolução no 500/2017, Disponível em: http://alerjln1.alerj.rj.gov.br/scpro1519.nsf/efb4ad1de8ed65fa832566ec0018d834/78e981b1fd f08dfb8325817600667dec?OpenDocument\&Start=1\&Count=200\&Expand=1.

Acesso em : 12 fev 2016.

PUSSETTI, C. O silêncio dos inocentes: Os paradoxos do assistencialismo e os mártires do Mediterrâneo. Interface. v. 21, n. 6, 2017, p. 263-272. Disponível em: http://www.scielo.br/pdf/icse/v21n61/1414-3283-icse-21-61-0263.pdf. Acesso em: 17 nov 2017.

RETCHMAN, R. (2000) De la psychiatrie des migrants au culturalisme des ethnopsychiatries. Santé, le traitement de la différence, no 1225, p. 46-61, mai-juin 2000. Disponível em: https://www.persee.fr/doc/homig_1142-852x_2000_num_1225_1_3510. Acesso em: 11 mai 2016.

RIBEIRO, D. (1995) O povo brasileiro: a formação e o sentido do Brasil. São Paulo: Cia de Bolso, 1995.

ROSA, M.D. A clínica psicanalítica em face da dimensão sociopolítica do sofrimento. São Paulo: Editora Escuta, 2016.

Psicanálise implicada: vicissitudes das práticas clínico-políticas. Revista da Associação Psicanalítica de Porto Alegre, no 41-42. Porto Alegre: APPOA, 2012a.

Migrantes, imigrantes e refugiados: A clínica do traumático. Revista de Cultura e Extensão USP, 7, 67-76, 2012 b. 
A pesquisa psicanalítica dos fenômenos sociais e políticos: metodologia e fundamentação teórica. Revista Mal-estar e Subjetividade, v. 4, no 2. Fortaleza, 2004.

. O não-dito familiar e a transmissão da história. Psychê, v.v, no. 8, julho-dezembro, 2001, p. 123-137, 2001.

; BERTA, S; Angústia e luto no exílio político. Textura, v. 5, p. 52-56, 2006.

; BERTA, S.; ALENCAR, S. CARIGNATO, T.A condição errante do desejo: os imigrantes, migrantes, refugiados e a prática psicanalítica clínicopolítica. Rev. Latinoam. Psicopat. Fundamental, v. 12, n. 3, p. 497-511, setembro 2009.

; CARIGnato, T. T.; AlenCAR, S. L. (Orgs) Desejo e Política: desafios e perspectivas no campo da imigração e refúgio. São Paulo: Ed. Max Limonad, 2013.

; DOMINGUES, E.O método na pesquisa psicanalítica de fenômenos sociais e políticos: a utilização da entrevista e da observação. Psicologia e Sociedade, v.22, no.1, Florianópolis, 2010.

.; NOGUEIRA, T. S. Intimidade e alteridade: a experiência do refúgio e a clínica psicanalítica. Calibán Revista Latino Americana de Psicanálise. Tema: Intimidade, v.15, n.1, 2017.

ROUDINESCO, E.; PLON, M. Dicionário de psicanálise. (Trad. Vera Ribeiro, Lucy Magalhães). Rio de Janeiro: Zahar, 1998.

SAGLIO-YATZIMIRSKY, M-C La voix de ceux qui crient : Rencontre avec des demandeurs d'asile. Paris : Éditions Albin Michel, 2018.

Le trauma : du retournement de la culture à la nature humaine. In: P. BONIN \& T. POZZO. Nature ou culture, Publications de l'Université de Saint Etienne, Colloque de l'Institut Universitaire de France, 2014. Disponível em: https://hal-inalco.archivesouvertes.fr/hal-01279259/document. Acesso em: 12 ab 2016.

.Do relatório ao relato, da alienação ao sujeito: a experiência de uma prática clínica com refugiados em uma instituição de saúde. Psicol. USP, v.26 no.2 São Paulo May/Aug. 2015b

Dignité/indignité : une anthropologie des corps aliénés. Colloque em Liège, 8 outubro 2016. Disponível em: http://www.mcsy.fr/?p=5176. Acesso em: 17 abril 2018.

.Temps du trauma, terre de l'asile, in Migrations, réfugiés, exil. Dir. P. Boucheron. Colloques Collège de France, Odile Jacob, pp. 201-216. 2017.

; GEBRIM, A. (2017) Nouvelles migrations au Brésil : des représentations de l'accueil aux formes contemporaines de racisme », Brésil(s) 12, 2017. Disponível em : https://journals.openedition.org/bresils/2313. Acesso em : 28 março 2018. 
SARTHOU-LAJUS, N. ; RECHTMAN, R. Enquête sur la condition de victime. Etudes, Tome 414, p. 175-186, 2011.

SAYAD, A. La double absence. Paris : Seuil, 1999.

L'immigration ou les paradoxes de l'altérité, Paris : Raison d'agir, 2006.

SELIGMAN-SILVA, M. (2008) Narrar o trauma: A questão dos testemunhos de catástrofes históricas. Psic. Clin. (R.J), v.20, no.1, p.65- 82, 2008.

SCHUCMAN, L. V. Entre o encardido, o branco e o branquíssimo: branquitude, hierarquia e poder na cidade de São Paulo. São Paulo: Annablume, 2014.

SÃO PAULO. Lei no. 16.478, DE 8 DE JULHO DE 2016. Institui a Política Municipal para a População Imigrante, dispõe sobre seus objetivos, princípios, diretrizes e ações prioritárias, bem como sobre o Conselho Municipal de Imigrantes.

SONTAG, S. Diante da dor dos outros. São Paulo: Companhia das Letras, 2003.

SZEKACS-WEISZ; J.;WARD. I. (Orgs) Lost chilhood and the language of exil. London: Imago LMPC and The Freud Museum, 2004.

TAUSK, V. Contribución a la psicología del desertor. Affectio Societatis, no 9, diciembre, $2008 . \quad$ Disponível em: http://aprendeenlinea.udea.edu.co/revistas/index.php/affectiosocietatis/article/view/5333/4687 . Acesso em: 26 jan 2017.

TICKTIN, M. Casualties of care: Immigration and the politics of humanitarianism in France. Berkely (California): University of California Press, 2011.

TODOROV, T. A conquista da América: a questão do outro. São Paulo, Martins Fontes, 2010.

2008.

La Peur des barbares: Au-delà du choc des civilisations. Paris: Robert Laffont,

. L’homme dépaysé. Paris: Éditions du Seuil, 1996.

Face à l'extrême. Paris: Éditions du Seuil, 1991.

A conquista da América: a questão do outro. São Paulo: Martins Fontes, 1982

1989.

Nous et les autres, la réflexion française sur la diversité humaine. Paris: Seuil, Les abus de la mémoire. Paris: Ed. Arléa, 2004.

UCHITEL, M. Neurose traumática: Uma revisão crítica do conceito de trauma. São Paulo. Casa do psicólogo, 2011. 
VENTURA, D.; ILLES, P. Qual política migratória do Brasil? Le Monde Diplomatique, Brasil, mar 72012.

YAHIAOUI, A. Exil et déracinement: thérapie familiale des migrants. Paris: Ed. Dunod, 2010.

YANKELEVICH, H. (1993) A mãe da palavra. In: Association Freudiène Internationale. Um inconsciente pós-colonial, se é que ele existe. Porto Alegre: Artes e ofícios. p. 43. 


\begin{abstract}
APÊNDICE
Beirute, Líbano, novembro de 2017: muito barulho, muito caos, muita informação, tensão, desigualdade, poluição, mas há também beleza. A cabeça não para nem um minuto de pensar e tentar observar e compreender tudo em volta. Acordo de manhã e não tem energia em casa, os cortes de energia são diários em todo o Líbano, e Beyrouth tem cerca de 3 horas de apagão por dia, além de interrupções aleatórias. Eu esperava um whatsapp às $9 \mathrm{~h}$ de um dos membros da organização que me levaria aos campos de refugiados palestinos na cidade. Mas nada de energia, muito menos de banho quente. Saio à procura de um café com wifi, tarefa nada fácil no bairro em que estamos, vou com minha mochila nas costas e não sei ainda o que o dia me reserva. Acho uma pequena lojinha de sucos com wifi, o dono só fala árabe, mas conseguimos nos comunicar, tomo um suco de romã e ele explica por telefone o endereço de onde estamos para que a pessoa venha me buscar.

Nos encontramos e vamos a pé para um campo perto dali, o Campo de Mar Elias, que existe desde os anos 1950 e onde vivem cerca de 3 mil pessoas. Logo na entrada, faixas do Hamas e a presença das ONGs. UNRWA logo na entrada, é ela que gere todos os campos oficiais de palestinos mundo afora. Gere apenas oficialmente, pois o controle e gestão de fato são feitos pelos partidos palestinos. Em dois dias, visito três campos de refugiados em Beyrouth e cercanias. Descubro uma realidade nova, um outro Líbano. Descubro um pouco do que é a vida dos palestinos que vivem por lá. Uma experiência de dois dias e que me atravessa profundamente, é difícil descrever, um esforço, tenho vontade de ficar só em silêncio. Me forço a contar para outras pessoas o que vi, me forço a botar no papel, gostaria de poder escrever mais longamente sobre as coisas que vi e ouvi. A partir dessas curtas andanças descubro mais de perto o que já sabia, a situação dos palestinos no mundo é uma catástrofe. No Líbano trata-se de um povo que vive uma segregação quase de apartheid. Ouço de um velho senhor, no dia seguinte, que a situação dos palestinos no Líbano é pior do que em Israel. Desde os anos 1990, a lei libanesa interdita o exercício de 72 profissões por palestinos (basicamente só lhes é reservado os trabalhos de construção, faxina, jardinagem) e palestinos são proibidos de serem proprietários de qualquer imóvel ou negócio, ou seja, não têm direito
\end{abstract}


algum sobre o lugar onde vivem. Além disso, não podem utilizar nenhum serviço público, nem de educação e nem de saúde.

Atualmente, estamos na quarta geração de palestinos nascidos no Líbano, quarta geração desde a Nakba ${ }^{65}$, quase 70 anos de gerações instaladas em um país sem nenhuma possibilidade de integração ou exercício de direitos. É como se meu bisavô tivesse sido expulso da Palestina, e eu, nascida no Brasil, ainda não fosse brasileira. Ser palestino e afirmar isso com unhas e dentes é o que lhes resta, é o que faz frente mais aguerrida à frase do sionista que na ocasião da Nakba proferiu: "os mais velhos morrerão e os mais novos esquecerão". Em cada esquina, uma bandeira palestina, Arafat também está presente por todas as partes, é quase figura onipresente. Ser palestino é a única e maior forma de resistência. Ando pelos campos e me sinto dentro de um gueto. Um gueto que não é murado, ainda, porque vários no Líbano já são, mas esses que visitei ainda não, e talvez em breve serão, não sei.

Minha referência estética é de uma favela, mas não se trata só de uma favela, é uma realidade paralela, paralela ao Estado, é a materialização do resto, de populações resto. População numerosa originária de outra expulsa violentamente de suas casas. Quase 70 anos de uma ferida completamente aberta. Todo palestino (mesmo que nascido no Líbano há 3 ou 4 gerações) diz vir de alguma cidade da Palestina: "Venho de Jaffah", sem nunca ter pisado lá. É a nostalgia do que não viveram. É a identidade de algo que nunca conheceram. Como não têm direito de retorno, nenhum palestino nascido fora da Palestina pode visitar sua terra, Israel controla todas as fronteiras da Palestina e nenhum palestino tem direito de entrar. Me deprime a falta de perspectiva.

De Mar Elias, vamos de carro para Chatila. Um mundo à parte. 17 mil pessoas vivendo lá. $70 \%$ de desemprego, o problema mais grave é a falta de perspectiva para os jovens. Emigrar é o único projeto possível, chegar à Europa é o sonho. Nos campos, as famílias que vivem melhor são as que têm parentes vivendo na Europa e que mandam dinheiro, grande parte da renda dos campos gira em torno desse novo exílio. Para os que ficam: o desemprego, o ócio, o perambular nas ruas, o tráfico de drogas (toda Beyrouth vai aos campos comprar drogas baratas), criminalidade e o recrutamento por partidos islâmicos que pagam mesadas aos jovens em troca de tarefas partidárias. Em Chatila, sou novamente

\footnotetext{
${ }^{65}$ Nakba, em árabe, significa catástrofe, e se refere ao êxodo da população palestina em 1948 quando mais de 700.000 pessoas foram expulsas de suas casas.
} 
recebida por algumas lideranças que me contam sobre suas atividades: formação, workshop de costura pra mulheres, geração de renda.

Nos campos parece imperar uma dependência estrutural em relação à UNRWA. Como os palestinos não podem frequentar o ensino público libanês, dependem das escolas geridas pela ONU dentro dos campos (nem todo campo tem escolas para todas as idades). Os palestinos que eventualmente puderam pagar uma universidade privada ou que estudaram em outro país exercem a profissão de médico ou professor dentro dos campos, em organizações humanitárias ou de forma paralela. É a UNRWA, portanto, que diante da ausência e desamparo do Estado vem cumprir um papel de Estado, mas não exatamente como garantia de direito, pois trata-se de modos de governabilidade humanitária.

Enquanto andamos pelos becos estreitos dos campos, me ocorre uma pergunta ingênua, e depois me envergonho. Pergunto como as pessoas fazem para receber um correio, ou uma encomenda. A pessoa que me acompanha ri e me diz que nada disso é possível. Não existe correspondência nos campos, oficialmente essas casas não existem, o Estado não entra ali. As ruas são estreitas, tudo é um labirinto, para quem é de fora é impossível se achar em um campo, em algumas ruas é preciso abaixar a cabeça pois o teto de toda a extensão dos campos é um emaranhado sólido de fiação. É o grande teto dos campos. Alguém brinca comigo: o teto de fios é o que nos protege dos mísseis. Mas depois fico sabendo que todos os meses morrem pessoas eletrocutadas. No mês passado morreram 5 pessoas. Luz, água e wifi, tudo passa por ali, tudo emaranhado, desencapado. De fato, quase não se vê o céu olhando para cima, e de cima dos apartamentos mal se vê quem está embaixo. Tudo em alta tensão.

Há muito comércio por todas as partes no campo, toda uma economia girando internamente. Desde a guerra da Síria, há sete anos, todos os campos receberam sírios, e hoje eles representam às vezes mais do que a metade das populações. Uma grande liderança de um movimento me recebeu em sua casa no dia seguinte. Ali, ele conta que como refugiados os palestinos têm obrigação de acolher os sírios. A memória da guerra civil do Líbano ainda é muito latente. Há também a guerra dos campos dos anos 1990, em que os campos foram sitiados e guerrearam internamente. Visito memoriais e tumbas. A mulher que nos acompanha vivia lá nessa época e conta das dificuldades que viveu, ninguém tinha direito de entrar nem sair dos campos, durante três anos. Essa marca é muito mais recente do que o massacre ocorrido em 1982. 
No dia anterior, na terça-feira, tive uma aproximação tímida do que viriam a ser os dois dias seguintes. Desde o apartamento em que estava hospedada, fui até Sabra (Sabra e Chatila são internacionalmente conhecidos pelo massacre perpetrado pelos falangistas - grupo armado cristão na época da guerra civil do Líbano - que matou mais de 3000 pessoas, entre palestinos e libaneses xiitas). A pé, pude acompanhar a paisagem de Beirute mudar gradativamente até entrar no meio do grande mercado de rua de Sabra. Minha sensação era de estar dentro de uma foto dessas tão veiculadas do campo de Yarmouk (o maior campo de refugiados palestinos, campo que foi praticamente todo destruído em Damasco) ou qualquer outra imagem de jornal. Um conglomerado imenso de pessoas. Muito caos, bastante pobreza. Alimentos e lixo, tudo dividindo um espaço muito pequeno, um mundo fervendo dentro de Beyrouth.

Em uma outra ocasião vou até o campo de Borj Borajneh, numa periferia distante de Beirute. 35 mil pessoas moram ali, eram 17 mil até 2012, e depois da guerra da Síria metade da população é de refugiados sírios. Me sinto entrando de novo em outro mundo. Visito a casa de uma liderança do campo, no alto de um prédio, uma casa construída por ele, mas que oficialmente não existe. Lá sentamos na sala e tomamos um chá com bolachas servido por sua mulher - que senta no canto da sala, ouve tudo atenta, e às vezes faz um comentário ou outro - enquanto ele me conta a história do campo. Está conosco também um companheiro seu, um palestino nascido na Síria, que veio ao Líbano antes da guerra, e vive aqui com seus cinco filhos e mulher (ele conta que, uma vez, uma jornalista australiana lhe fez a proposta de ajudar toda a sua família a emigrar para a Austrália, ao que ele negou porque diz que seu destino é permanecer junto à luta dos palestinos nos campos).

Tudo ali começou nos anos 1950, no princípio eram barracas, nos anos 60, começaram as primeiras casas de zinco, e nos anos 70 a construção de casas. O campo era todo murado e a entrada tinha uma largura de 80 centímetros, tudo tinha que passar por ali. Foi a partir de 1975, quando começou a guerra-civil no Líbano, em meio ao caos político do país, que as primeiras casas começaram a ser construídas, pois não havia governo para fiscalizar ou interditar as construções. Em 82, Israel invadiu esse campo. Em 87, houve uma guerra interna entre os partidos palestinos. Em 2012, a mais recente transformação: depois da guerra da síria, o campo dobrou de tamanho.

Fico emocionada por escutar três pessoas mais velhas me contando sobre a história do campo, história de resistência e de luta. Transpareço minha emoção, tenho os olhos cheios de 
lágrimas, fico segurando para não chorar muito. Um dos senhores me olha e diz que de fato todo jornalista (ele pensou que eu fosse uma) que os visita nunca sai com o mesmo estado psicológico que entrou.

Com dois deles, saio para andar no campo. É enorme, novamente labirintos de ruas, crianças indo e vindo das escolas, cafés, mercados e farmácias, um mundo acontecendo, o mesmo teto preto de fiação, fotos de Arafat e imagens palestinas por todo lado. 


\section{ANEXO A - Autorização para realização da pesquisa}

(Caritas Arquidiocesana de São Paulo)

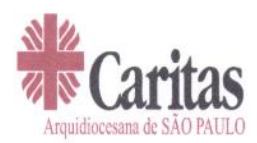

"Deus é amar: quem permanece no omor, permanecee em Deus
e Deus permanece nele." 104,16

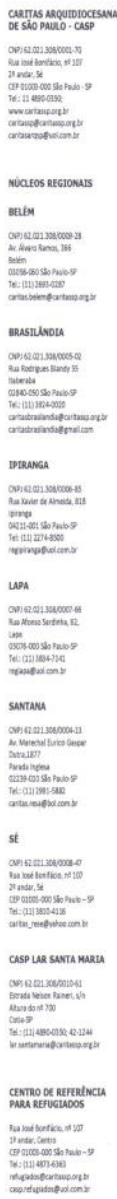

Autorizaçăo para realizaçāo de pesquisa

Eu, Maria Cristina Morelli, coordenadora do Centro de Referência para Refugiados Caritas Arquidiocesana de Sảo Paulo, venho por meio desta informar que autorizo a pesquisadora Ana Carolina Campos Gebrim, aluna do curso de Doutorado em Psicologia Clinica do Instituto de Psicologia da Universidade de Săo Paulo - USP, a realizar a sua pesquisa de doutoramento intitulada provisoriamente como: "Migraçōes e clinica: dispositivos de saúde mental e o contexto brasileiro" sob orientação da Profa. Dra. Miriam Debieux Rosa. Declaro conhecer e cumprir as Resoluçōes Éticas Brasileiras, em especial a Resolução CNS 466/12. Declaro igualmente reconhecer que todos os dados resultantes da pesquisa såo confidenciais e sua identidade será mantida em sigilo nas divulgaçōes posteriores. Tais informaçōes poderão ser utilizadas para fins acadêmicos, podendo também ser apresentadas em congressos, publicaçōes ou outra forma de divulgação nacional ou internacional. Esta instituiçăo está ciente de suas corresponsabilidades como instituiç̧öo coparticipante do presente projeto de pesquisa, e de seu compromisso no resguardo da segurança e bem-estar dos sujeitos de pesquisa nela recrutados, dispondo de infraestrutura necessária para a garantia de tal segurança e bem estar.

São Paulo, 07 agosto, 2015

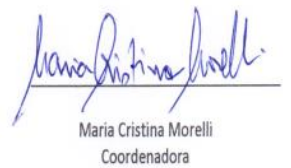

Centro de Referência para Refugiados 


\title{
Anexo B - Termo de convênio para atividades de extensão entre a Missão Paz e o Grupo Veredas: Imigração e Psicanálise
}

\author{
Termo de convênio para atividades de extensão entre Missão Paz e Grupo \\ Veredas: Imigração e Psicanálise
}

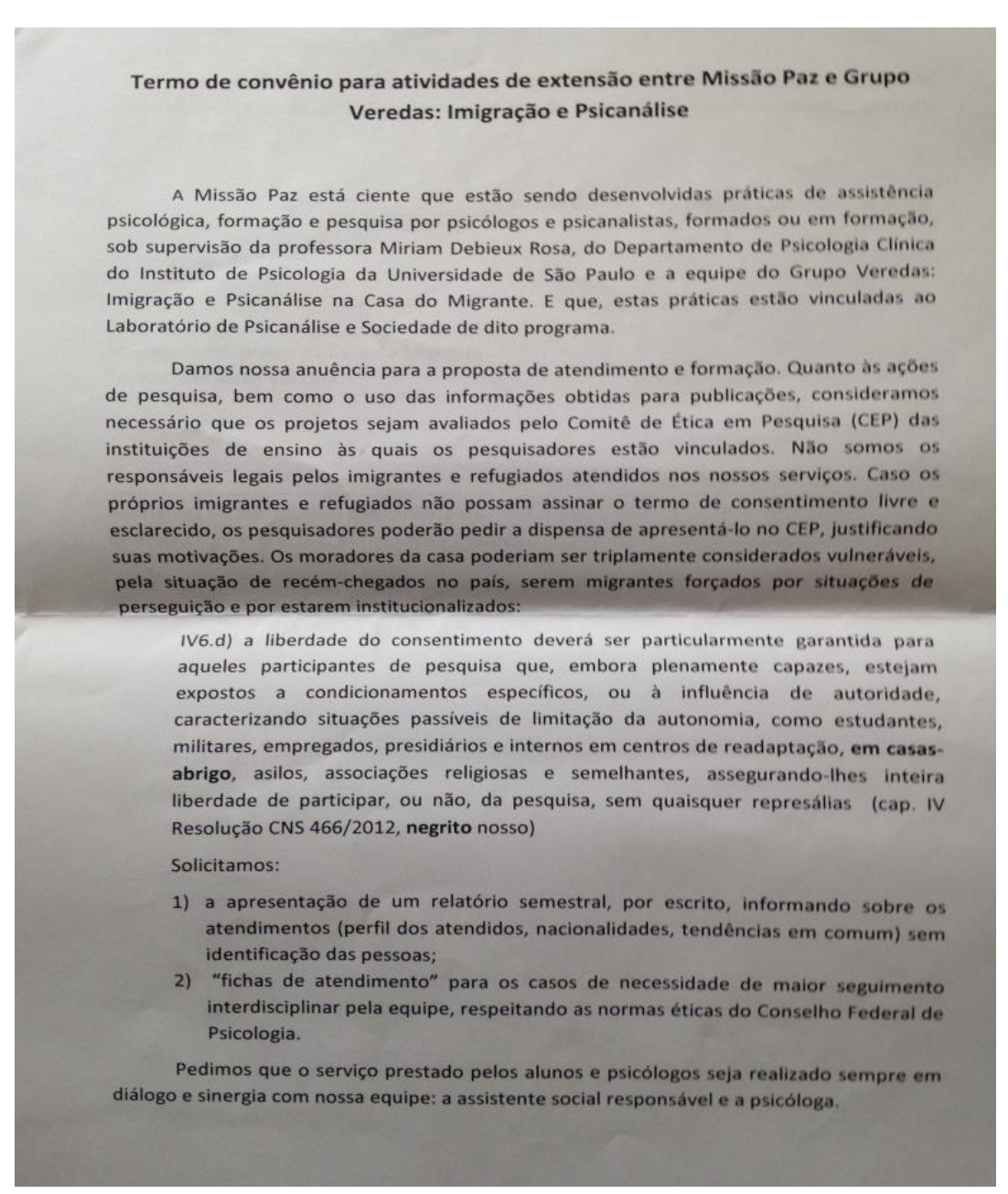


Firmamos esse acordo, com essas condições a entrarem em vigor a partir desta data até início de março de 2019. Solicitamos renovação anual, condicionada ao cumprimento do acima descrito.

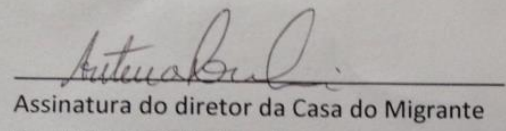

Pe. Antenor Dalla Vecchia

Assinatura do responsável pelo projeto de intervenção - Profa. Dra. Miriam Rosa Debieux 